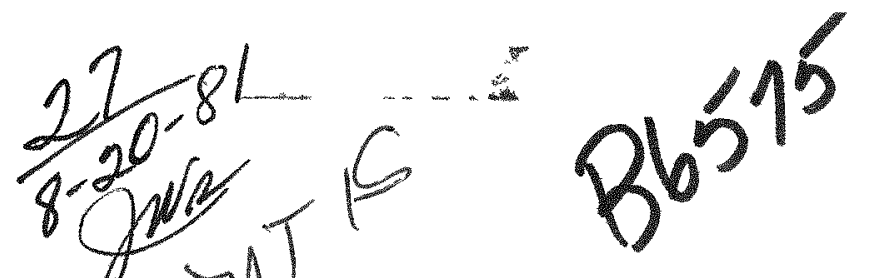

\title{
ENGINEERING ASSESSMENT OF INACTIVE URANIUM MILL TAILINGS
}

\section{GRAND JUNCTION SITE GRAND JUNCTION, COLORADO}

\author{
JULY 1981
}

PREPARED FOR

UNITED STATES DEPARTMENT OF ENERGY

ALBUQUERQUE OPERATIONS OFFICE

URANIUM MILL TAILINGS

REMEDIAL ACTIONS PROJECT OFFICE

ALBUQUERQUE, NEW MEXICO

CONTRACT NO. DE-AC04-76GJ01658

BY

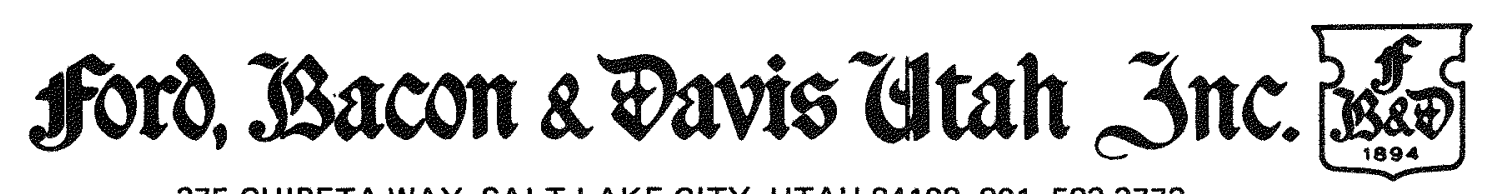

375 CHIPETA WAY, SALT LAKE CITY, UTAH 84108801 583-3773 


\section{DISCLAIMER}

THIS REPORT WAS PREPARED AS AN ACCOUNT OF WORK SPONSORED BY THE UNITED STATES GOVERNMENT. NEITHER THE UNITED STATES NOR THE UNITED STATES DEPARTMENT OF ENERGY, NOR ANY OF THEIR EMPLOYEES, MAKES ANY WARRANTY, EXPRESS OR IMPLIED, OR ASSUMES ANY LEGAL LIABILITY OR RESPONSIBILITY FOR THE ACCURACY, COMPLETENESS, OR USEFULNESS OF ANY INFORMATION, APPARATUS, PRODUCT, OR PROCESS DISCLOSED. OR REPRESENTS THAT ITS USE WOULD NOT INFRINGE PRIVATELY OWNED RIGHTS. REFERENCE HEREIN TO ANY
TRADE NAME, MARK, MANUFACTURER OR OTHERWISE, DOES NOT NECESSARILY CONSTITUTE Ó IMPLYY ITS ENDORSEMENT, RECOMMENDATION, OR FAVORING BY THE UNITED STATES GOVERNMENT OR ANY AGENCY THEREOF. THE VIEWS AND OPINIONS OF AUTHORS EXPRESSED HERE DO NOT NECESSARILY STATE OR RE. FLECT THOSE OF THE UNITED STATES GOVERNMENT OR ANY AGENCY THEREOF. 


\section{DISCLAIMER}

This report was prepared as an account of work sponsored by an agency of the United States Government. Neither the United States Government nor any agency Thereof, nor any of their employees, makes any warranty, express or implied, or assumes any legal liability or responsibility for the accuracy, completeness, or usefulness of any information, apparatus, product, or process disclosed, or represents that its use would not infringe privately owned rights. Reference herein to any specific commercial product, process, or service by trade name, trademark, manufacturer, or otherwise does not necessarily constitute or imply its endorsement, recommendation, or favoring by the United States Government or any agency thereof. The views and opinions of authors expressed herein do not necessarily state or reflect those of the United States Government or any agency thereof. 


\section{DISCLAIMER}

Portions of this document may be illegible in electronic image products. Images are produced from the best available original document. 
DOE/UMT-0105

FBDU-360-09

UC 70

\section{ENGINEERING ASSESSMEN' \\ OF INACTIVE URANIUM MILL TAILINGS}

GRAND JUNCTION SITE

GRAND JUNCTION, COLORADO

July 1981

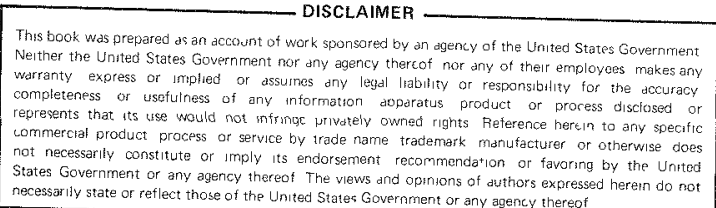

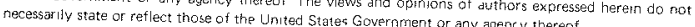

prepared for

U.S. DEPARTMENT OF ENERGY

ALBUOUERQUE OPERATIONS OFEICE

URANTUM MILL TAILINGS REMEDIAL ACTIONS

PROJECT OFFICE

ALBUQUERQUE, NEW MEXICO

Contract NO. DE-ACO4-76GJO1658

By

FORD, BACON \& DAVIS UTAH INC.

375 Chipeta Way

salt Lake City, Utah 84108 


\section{NOTICE}

This engineering assessment has been performed under DOE Contract No. DE-ACO4-76GJO1658 between the U.S. Department of Energy and Ford, Bacon \& Davis Utah Inc.

Copies of this report may be obtained from the Uranium Mill Tailings Remedial Action project office, U.S. Department of Energy. Albuquerque operations Office, Albuquerque, New Mexico 87115. 
FOREWORD

This report has been authorized by the U.S. Department of Energy (DOE), Albuquerque operations office, Uranium Mill Tailings Remedial Action project office, Albuquerque, New Mexico, under Contract No. DE-AC04-76GJO1658. The report is a revision of an earlier report dated october 1977, entitled "Phase II - Title I Engineering Assessment of Inactive Uranium Mill Tailings, Grand Junction Site, Colorado," which was authorized by DOE, Grand Junction, Colorado, under Contract No. $E(05-1)-1658$.

This report has become necessary as a result of changes that have occurred since 1977 which pertain to the Grand Junction site and vicinity, as well as changes in remedial action criteria. The new data reflecting these changes are presented in this report. Evaluation of the current conditions is essential to assessing the impacts associated with the options suggested for remedial actions for the tailings.

Ford, Bacon \& Davis Utah Inc. (FB\&DU) has received excellent cooperation and assistance in obtaining new data to prepare this report. Special recognition is due Richard $\mathrm{H}$. Campbell and Mark Matthews of DOE, R. Shumway of Sand Extraction Company, and John Bouella, Carter Elliott, Donald Sullivan, and R.G. Sullivan of BESS Investments. Several local, county, and state agencies contributed information, as did many private individuals. 


\section{ABSTRACT}

Ford, Bacon \& Davis Utah Inc. has reevaluated the Grand Junction site in order to revise the october 1977 engineering assessment of the problems resulting from the existence of radioactive uranium mill tailings at Grand Junction, Colorado. This engineering assessment has included the preparation of topographic maps, the performance of core drillings and radiometric measurements sufficient to determine areas and volumes of tailings and radiation exposures of individuals and nearby populations, the investigations of site hydrology and meteorology, and the evaluation and costing of alternative corrective actions.

Radon gas released from the 1.9 million tons of tailings at the Grand Junction site constitutes the most significant environmental impact, although windblown tailings and external gamma radiation are also factors. The eight alternative actions presented herein range from millsite and off-site decontamination with the addition of $3 \mathrm{~m}$ of stabilization cover material (option I), to removal of the tailings to remote disposal sites and decontamination of the tailings site (Options II through VIII). Cost estimates for the eight options range from about $\$ 10,200,000$ for stabilization in-place to about $\$ 39,500,000$ for disposal in the DeBeque area, at a distance of about $35 \mathrm{mi}$, using transportation by rail. If transportation to DeBeque were by truck, the cost is estimated to be about $\$ 41,900,000$.

Three principal alternatives for the reprocessing of the Grand Junction tailings were examined:

(a) Heap leaching

(b) Treatment at an existing mill

(c) Reprocessing at a new conventional mill constructed for tailings reprocessing.

The cost of the uranium recovered would be about $\$ 200 / 1 \mathrm{~b}$ by heap leach and $\$ 150 / 1 b$ by conventional plant processes. The spot market price for uranium was $\$ 25 / 1 b$ early in 1981 . Therefore, reprocessing the tailings for uranium recovery appears not to be economically attractive. 
Notice. . . . . . . . . . . . . . . . ii

Foreword. . . . . . . . . . . . . . . . . . iii

Abstract. . . . . . . . . . . . . . . . . . iv

List of Figures . . . . . . . . . . . . . . . x

List of Tables. . . . . . . . . . . . . . . . xiii

1 SUMMARY . . . . . . . . . . . . . 1 . 1

1.1 Introduction ............... . 1-1

1.1.1 Background. . . . . . . . . . 1-3

1.1.2 Scope of Phase II Engineering

Assessment. . . . . . . . . . 1-4

1.2 Site Description . . . . . . . . . 1-6

1.2.1 Location and Topography . . . . . 1-6

1.2.2 Ownership and History of Milling

Operations and Processing . . . . 1-7

1.2.3 Present Condition of the site... . 1-7

1.2.4 Tailings and soil Characteristics . . 1-7

1.2.5 Geology, Hydrology, and

Meteorology . . . . . . . . . 1-8

1.3 Radioactivity and Pollutant Impacts

on the Environment ............ 1-9

1.3.1 Radiation Exposure Pathways,

Contamination Mechanisms, and

Background Levels . . . . . . . 1-9

1.3.1.1 Radon Gas Diffusion and

1.3 .1 .2 Direct Gama Radiation : $\cdot 1-9$

1.3.1.3 Windblown Contarninants . . 1-10

1.3.1.4 Ground and surface water

1.3.1.5 Soil contamination $\cdot \cdot \cdot \cdot \cdot 1-11$

1.3.2 Remedial Action Criteria...... . 1-11

1.3.3 Potential Health Impact. . . . . . 1-13

1.3.4 Nonradioactive Pollutants..... . 1-16

1.4 Socioeconomic and Land Use Impacts . . . . 1-16

1.5 Recovery of Residual Values. . . . . . . 1-17

1.6 Mill Tailings Stabilization. . . . . . . . . 1-17

1.7 Off-site Remedial Action . . . . . . . . 1-18 
TABLE OF CONTENTS (Cont)

Chapter

Title

$\underline{\text { Page }}$

1.8 Disposal Site Selection. . . . . . . . 1-19

1.9 Remedial Actions and Cost-Benefit

Analyses . . . . . . . . . . . . . . 1-19

1.9.1 Remedial Action Options . . . . . 1-19

1.9 .2 Cost-Benefit Analyses... . . . 1-20

Chapter 1 References. . . . . . . . . . . 1-26

SITE DESCRIPTION . • . . . . . . . . . . . 2-1

2.1 Location . . . . . . . . . . . . . 2-1

2.2 Topography . . . . . . . . . . . . 2-1

2.3 Ownership. . . . . . . . . . . . . . . 2-2

2.4 History of Milling Operations and

processing . . . . . . . . . . . . . 2-2

2.5 Present Condition of the site. . . . . . . 2-3

2.6 Tailings and Soil Characteristics. . . . . 2-4

2.7 Geology, Hydrology, and Meteorology. . . . 2-5

2.7.1 Geology . . . . . . . . . . 2-5

2.7.2 Surface Water Hydrology . . . . . 2-5

2.7.3 Ground Water Hydrology. . . . . . 2-6

2.7 .4 Meteorology .......... . 2-7

Chapter 2 References. . . . . . . . . . . 2-21

3 RADIOACTIVITY AND POLLUTANT IMPACT ON THE

ENVIRONMENT . . . . . . . . . . . . . . . 3-I

3.1 Radioactive Material Characteristics . . . 3-1

3.2 Radiation Effects. . . . . . . . . . . 3-2

3.3 Natural Background Radiation . . . . . . . 3-3

3.4 Radiation Exposure Pathways and

Contamination Mechanisms . . . . . . . 3-4

3.4.1 Radon Gas Diffusion and Transport . 3-5

3.4.2 Direct Gamma Radiation. . . . . 3-6

3.4.3 Windblown Contaninants. . . . . . 3-7

3.4.4 Ground and surface Water

Contamination . . . . . . . . . 3-8

3.4.5 Soil Contamination. . . . . . . . 3-9

3.4 .6 Off-Site Tailings Use . . . . . . $3-9$

3.5 Remedial Action Criteria. . . . . . . 3-9 
TABLE OF CONTENTS (Cont)

Chapter

$$
\text { Title }
$$

Page

3.5.1 EPA Interim and proposed Standards. - 3-10 3.5.2 NRC Regulations on Uranium Mill

Tailings......... . 3-12

3.6 Potential Health Impact. . . . . . . 3-14

3.6.1 Assumptions and Uncertainties in

Estimating Health Effects .... 3-15

3.6.2 Health Effects. . . . . . 3-18

3.7 Nonradioactive Pollutants. . . . . 3-20

Chapter 3 References. . . . . . . . 3-46

4 SOCIOECONOMIC AND LAND USE IMPACTS. . . . . . 4-1

4.1 Socioeconomic Background . . . . . . . 4-1

4.2 population Estinates . . . . . . . . . 4-2

4.3 Land Use............... . 4-3

4.4 Impact of the Tailings on Land Values. . . 4-4

Chapter 4 References. . . . . . . . 4-11

5 RECOVERY OF RESIDUAL VALUES ........ . 5-1

5.1 process Alternatives . . . . . . . 5-1

5.1 .1 Heap Leaching . . . . . . . . 5-1

5.1.2 Treating in an Existing Plant... 5-3

5.1.3 Treating in a New Mill....... 5-3

5.2 Grand Junction Recovery Economics. . . . 5-3

5.2.1 Market for Uranium. . . . . . 5-3

5.2.2 Escalation of Plant Construction

Cost. . . . . . . . . . . 5-4

5.2.3 Escalation of Plant operating

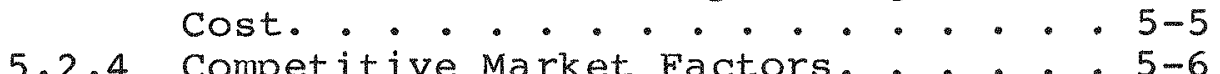

5.3 Conclusion . . . . . . . . 5-6

chapter 5 References.......... 5-15

6 MILL TAILINGS STABILIZATION . . . . . . 6-1

6.1 Prevention of wind and water Erosion . . . 6-1 
TABLE OF CONTENTS (Cont)

6.1.1 Surface Stabilization...... . 6-2

6.1 .2 volumetric stabilization. . . . . 6-3

6.1.3 Physical stabilization. . . . . . 6-4

6.1.4 Vegetative Stabilization. . . . . 6-5

6.2 Prevention of Leaching . . . . . . . . 6-6

6.3 Reduction of Radon Exhalation. . . . . . 6-7

6.4 Reduction of Gamma Radiation ....... . . 6-8

6.5 Assessment of Applicability. . . . . . . 6-8

Chapter 6 References. . . . . . . . . 6-13

7 OFE-SITE REMEDIAL ACTION . . . . . . . . . . 7-1

Chapter 7 References. . . . . . . . . . 7-2

8 DISPOSAL SITE SELECTION . . . . . . . . . 8-1

8.1 Criteria for Disposal. . . . . . . . . 8-1

8.2 Descriptions of Disposal Sites

Considered as Options. . . . . . . . 8-3

8.2.1 Whitewater Hill, site 14

(Option II) .......... . 8-3

8.2.2 Grasso Mine Road, site 2

(Option III). . . . . . . . . . 8-4

8.2.3 Indian Wash, Site 7 (option IV) . . 8-4

8.2.4 East orchard Mesa, Site 19

(Option V). . . . . . . . . . 8-5

8.2.5 North Whitewater Creek, site 20

(Option VI)......... 8-6

8.2.6 East Coal Canyon, site 21

(Option VII). . . . . . . . . 8-6

8.2.7 Unspecified Site Near DeBeque,

Site 22 (Option VIII) . . . . . 8-7

REMEDIAL ACTIONS AND COST-BENEFIT ANALYSES. . . 9-1

9.1 Stabilization of the Tailings on site

with a 3-Meter Cover (Option I). . . . . 9-2

9.1.1 Conceptual Design . . . . . . . 9-2

9.1.2 Costs for stabilization in Place. . . 9-3

9.2 Removal of Tailings and All

Contaminated Materials from the

Site (options II through VIII) . . . . . 9-3 


\section{TABLE OF CONTENTS (Cont)}

Chapter

Title

$\underline{\text { Page }}$

9.2.1 Excavation and Loading of Tailings and soils. . . . . . . . . . 9-4

9.2.2 Transportation of the Materials . . 9-4

9.2.3 Disposal at Alternative Sites. . . 9-6

9.3 Analyses of Costs and Benefits... . . . 9-7

9.3.1 Health Benefits......... . 9-7

9.3.2 Land Value Benefits... . . . . 9-8

Chapter 9 References. . . . . . . . . . 9-14

GLOSSARY . . . . . . . . . . . . . . . G-1 


\section{LIST OF FIGURES}

Number

Title

$\underline{\text { Page }}$

2-1 Aerial photograph of site . . . . . . . . . 2-9

2-2 Topographic Map . . . . . . . . . . . . 2-10

2-3 Land Ownership and Site Designation Map . . . . 2-Il

2-4 Descriptive Map . . . . . . . . . . . . 2-12

2-5 Cross-Section at Station 19+00. . . . . . . 2-13

2-6 Simplified Stratigraphic Column . . . . . . . 2-14

2-7 Surface Drainage and Man-Made Water systems . . 2-15

2-8 Recorded Artesian Wells, Grand Junction Area. . 2-16

2-9 Prevailing Wind Directions. . . . . . . . . 2-17

2-10 Grand Junction Airport Surface Wind Rose

(Cumulative Data from 1948 through 1956). . . 2-18

3-1 Radioactive Decay Chain of Uranium-238. • • . . 3-21

3-2 Locations for ${ }^{226}$ Ra Background samples. . . . 3-22

3-3 Radon Canister Locations and Flux Values. . . . 3-23

3-4 Radon concentration in Vicinity of Pile . . . . 3-24

3-5 222Rn and Atmospheric Transients at NW

3-6 222 $\mathrm{Rn}$ and Atmospheric Transients $0.08 \mathrm{MI}$

WNW of Pile on June 2, 1976 . . . . . . . . 3-26

3-7 Reduction of outdoor $222 \mathrm{Rn}$ concentration

with Distance from the Tailings Pile. . . . . 3-27

3-8 Gamma Levels at Site 3 Ft above Ground. . . . . 3-28

3-9 Gamma Levels in Vicinity 3 Ft above Ground. . . . 3-29

3-10 Reduction of External Gamma Radiation

Levels with Distance from the Tailings Pile . . 3-30

3-11 EPA Gamma Survey Surrounding Millsite . . . . . 3-31 


\section{LIST OF FIGURES (Cont)}

Number

Title

Page

3-12 Off-Site Windblown Contamination Survey . . . . 3-32

3-13 Surface and subsurface Radium Concentrations. . 3-33

3-14 Radiometric profile at Drill Hole GJC-14. . . . 3-34

3-15 Radiometric profile at Drill Hole GJC-1 . . . 3-35

3-16 Radium Activity Concentration in Contaminated

subsoil . . . . . . . . . . . . 3-36

3-17 Lung Cancer Risk from Continuous Exposure
to Radon Gas. . . . . . . . . . . . - . 37

4-1 Map of Mesa County Boundaries . . . . . . . 4-6

4-2 Population Projections. . . . . . . . . . 4-7

4-3 Vicinity Land Use... . . . . . . . . 4-8

4-4 Assessed Value of Land (30\% Level). . . . . . 4-9

5-1 Uranium Recovery from Mill Tailings as a
Function of $\mathrm{U}_{3} \mathrm{O}_{8}$ Content in Tailings. . . . . 5-7

5-2 Construction Costs of Heap Leaching Plant

to Reprocess Uranium Mill Tailings

(Cost Adjusted to July 1980). . . . . . . . 5-8

5-3 Construction Costs of a Conventional Uranium

Mill to Reprocess Tailings W/O Crushing and

Grinding Facilities or Tailings Stabilization

Costs (Cost Adjusted to July 1980). . . . . . 5-9

5-4 Operating Costs of Heap Leaching of Uranium

Mill Tailings . . . . . . . . . . . . . 5-10

5-5 Operating Costs of Conventional Milling $\mathrm{W} / \mathrm{O}$

Crushing and Grinding Facilities to Reprocess

Tailings (Cost Adjusted to July 1980) . . . . 5-11

6-1 Exponential Moisture Dependence of the

Diffusion Coefficient . . . . . . . . . . 6-10

6-2 Reduction of Radon Exhalation Flux with

Depth of Cover.............. . . 6-11 


\section{LIST OF FIGURES (Cont)}

Number

Title

Page

6-3 Reduction of Gamma Exposure Rate Resulting

from Packed Earth Shielding . . . . . . . . 6-12

8-1 Location of Proposed Disposal Sites... . . . 8-8

9-1 Area Decontamination Plan . . . . . . . . . 9-9

9-2 Schematic of Typical Tailings Disposal site. . 9-10

9-3 Potential Cancer Cases Avoided Per Million

Dollars Expended. . . . . . . . . . . 9-11 


\section{LIST OF TABLES}

Number

Title

$\underline{\text { Page }}$

1-1 Summary of Conditions Noted at Time of 1980 Site Visits. . . . . . . . . . . . . 1-21

1-2 Sumnary of Remedial Action Options and Effects . . . . . . . . . . . . . . 1-23

2-1 Weights and Volumes of on-Site Materials. . . 2-19

2-2 Physical Properties and pH of the Uranium

Tailings. . . . . . . . . . . . . 2-20

3-1 Notations and Abbreviations Used in

Chapter 3... . . . . . . . . . . . 3-38

3-2 Background Radiation Sources in Soil

from Northwest Colorado. . . . . . . . 3-40

3-3 Radiochemical Analysis of Grand Junction

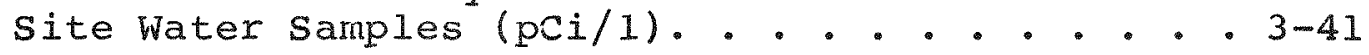

3-4 Estimated Health Impact from Grand Junction

Tailings for an Area 0 to 0.75 Mile from

Tailings Edge... . . . . . . . . . 3-42

3-5 Estimated Health Impact from Grand Junction

Tailings for an Area 0 to 6 Miles from

Tailings Edge . . . . . . . . . . . . . 3-43

3-6 Chemical Analyses of Grand Junction

Water Samples (mg/1). . . . . . . . . . 3-44

4-1 Estimated 1980 population Distribution. . . . 4-10

5-1 Assay Results of Composite Tailings and

Background Samples. . . . . . . . . . 5-12

5-2 U.S. Uranium Supply and Market Summary. . . . . 5-13

5-3 Estimated Uranium Costs from Grand Junction

Tailings. . . . . . . . . . . . . . 5-14

8-1 Sites Evaluated for Disposal of Grand Junction

Tailings. . . . . . . . . . . . . . 8-9

9-1 Summary of Stabilization and Disposal Costs . . 9-12

9-2 Potential Cancer Cases Avoided and Cost

Per Potential Case Avoided. . . . . . . . 9-13 
CHAPTER 1

SUMMARY 


\title{
CHAPTER 1
}

\author{
SUMMARY
}

\section{1 INTRODUCTION}

The U.S. Energy Research and Development Administration (ERDA) contracted in 1975 with Ford, Bacon \& Davis Utah InC. (FB\&DU) of salt Lake City, Utah, to provide architectengineering services and final reports based on the assessment of the problems resulting from the existence of large quantities of radioactive uranium mill tailings at inactive mill sites in eight western states and in pennsylvania. In 1980, the U.S. Department of Energy (DOE) contracted with FB\&DU to produce revised reports of the sites designated in the Uranium Mill Tailings Remedial Action (UMTRA) program in order to reflect the current conditions, new criteria and options, and to estimate current remedial action costs.

A preliminary survey (Phase I) was carried out in 1974 by the U.S. Atomic Energy Commission (AEC) in cooperation with the U.S. Environmental Protection Agency (EPA) and the affected states. In a summary report, (1) ERDA identified 17 sites in Arizona, Colorado, Idaho, New Mexico, Utah, and Wyoming for which practical remedial measures were to be evaluated. subsequently, ERDA added five additional sites (Riverton and Converse County, Wyoming; Lakeview, Oregon; Falls City and Ray Point, Texas). More recently, DOE has added a site in Canonsburg, Pennsylvania, one near Baggs, Wyoming, and two sites in North Dakota (Belfield and Bowman) and deleted Ray point, for a total of 25 sites. DOE continues to investigate the status of the site near Baggs, Wyoming. Most of the mills at these sites produced by far the greatest part of their output of uranium under contracts with the AEC during the period 1947 through 1970. After operations ceased, some companies made no attempt to stabilize the tailings, while others did so with varying degrees of success. Recently, concern has increased about the possible adverse effects to the general public from long-term exposure to low-level sources of radiation from the tailings piles and sites.

Prior to 1975, the studies of radiation levels on and in the vicinities of these sites were limited in scope. The data available were insufficient to permit assessment of risk to people with any degree of confidence. In addition, information on practicable measures to reduce radiation exposures and estimates of their projected costs was limited. The purposes of these recent studies performed by FB\&DU have been to update the information necessary to provide a basis for decision making for appropriate remedial actions for each of the 25 sites. 
Evaluations of the following factors have been included in this engineering assessment in order to assess the significance of the radiological conditions that exist today at the Grand Junction site:

(a) Exhalation of radon gas from the tailings

(b) On-site and off-site direct radiation

(c) Land contamination from windblown tailings

(d) Hydrology and contamination by water pathways

(e) Potential health impact

(f) Potential for extraction of additional minerals from the tailings

Investigation of these and other factors originally led to the evaluation of eight potential practicable remedial action alternatives. Since that time, some remedial action alternatives have been judged unacceptable because of new criteria that have been proposed. In the work performed in the preparation of this report, the remedial action alternatives are revised as follows:

(a) Option I - stabilization of tailings on site with a $3-m$ cover

(b) Option II - Disposal at site 14, Whitewater Hill, $6.5 \mathrm{mi}$ southeast of tailings pile

(c) Option III - Disposal at site 2, Grasso Mine Road, $10.5 \mathrm{mi}$ north of tailings pile

(d) Option IV - Disposal at site 7. Indian Wash, $9.5 \mathrm{mi}$ northeast of tailinys pile

(e) Option V - Disposal at site 19, East orchara Mesa, $11.5 \mathrm{mi}$ east-southeast of tailings pile

(f) Option VI - Disposal at site 20, North Whitewater creek, $11 \mathrm{mi}$ southeast of tailings pile

(g) Option VII - Disposal at site 21, East Coal Canyon, 11.1 mi northeast of tailings pile

(h) Option VIII - Disposal at site 22, unspecified site, $35 \mathrm{mi}$ from tailings pile

The estimated costs of carrying out the remedial work to implement each option depend on such parameters as the degree of decontamination to be achieved and the degree of stabilization necessary. 


\subsubsection{Background}

On March 12, 1974, the Subcommittee on Raw Materials of the Joint Committee on Atomic Energy (JCAE), Congress of the United States, held hearings on S. 2566 and H.R. 11378, identical bills submitted by Senator Frank E. Moss and Representative Wayne owens of Utah. The bills provided for a cooperative arrangement between the AEC and the state of Utah in the area of the vitro tailings site in salt Lake city.* The bills also provided for the assessment of and appropriate remedial action to limit the exposure of individuals to radiation from uranium mill tailings.

Dr. William D. Rowe, testifying on behalf of the EPA, pointed out that there are other sites with similar problems. He recommended the problem be approached as a generic one, structured to address the most critical problem first.

Dr. James L. Liverman, testifying for the AEC, proposed that a comprehensive study should be made of all such piles, rather than treating the potential problem on a piecemeal basis. He proposed that the study be a cooperative two-phase undertaking by the states concerned and the appropriate federal agencies, such as the AEC and EPA. Phase I would involve site visits to determine such aspects as their condition, ownership, proximity to populated areas, prospects for increased population near the site, and need for corrective action. A preliminary report then would be prepared which would serve as a basis for determining if a detailed engineering assessment (Phase II) were necessary for each millsite. The Phase II study, if necessary, would include evaluation of the problems, examination of alternative solutions, preparation of cost estimates and of detailed plans and specifications for alternative remedial action measures. This part of the study would include physical measurements to determine exposure or potential exposure to the public.

The Phase I assessment began in May 1974, with teams consisting of representatives of the AEC, the EPA, and the states involved visiting 21 of the inactive sites. The Phase I report was presented to the JCAE in october 1974. Table 1-1, adapted from Reference 1, summarizes the conditions in 1980. Based on the findings presented in the Phase I report, the decision was made to proceed with Phase II.

\footnotetext{
* The proceedings of these hearings and the summary Report on the phase I study were published by the JCAE as Appendix 3 to ERDA Authorizing Legislation for Fiscal Year 1976. Hearings before the subcommittee on Legislation, JCAE, on Fusion Power, Biomedical and Environmental Research; operational Safety; Waste Management and Transportation, Feb 18 and 27, 1975, Part 2 .
} 
On May 5, 1975, ERDA, the successor to AEC, announced that Ford, Bacon \& Davis utah Inc. of Salt Iake City, Utah, had been selected to provide the architect-engineering (A-E) services for Phase II. ERDA's Grand Junction, Colorado, office (GJO) was authorized to negotiate and administer the terms of a contract with FB\&DU. The contract was effective on June 23, 1975. The Salt Lake City Vitro site was assiyned as the initial task, and work began immediately. The original work at Grand Junction was performed from June 1 through June 8, 1976. The original Phase II - Title I Engineering Assessment was published in october $1977 .(2)$

On November 8, 1978, the Uranium Mill Tailings Radiation control Act of 1978 (PL 95-604) became effective. This legislation provides for state participation with the Federal Government in the remedial action for inactive tailings piles. Pursuant to requirements of PL 95-604, the EPA has the responsibility to promulgate remedial action standards for the cleanup of areas contaminated with residual radioactive material and for disposal of tailings. The U.S. Nuclear Regulatory Commission (NRC) has the responsibility for enforcing these standards.

In 1979. DOE established the UMTRA Program office in Albuquerque, New Mexico. Work on the program has since been directed by personnel in that office. The supplementary field work by $F B \& D U$ in support of this report was performed between August 4 and August $6,1980$.

\subsubsection{Scope of Phase II Engineering Assessment}

Phase II A-E services are divided into two stages: Title I and Title II.

Title I services include the engineering assessment of existing conditions and the identification, evaluation, and costing of alternative remedial actions for each site. Following the selection and funding of a specific remedial action plan, Title II services will be performed. These services will include the preparation of detailed plans and specifications for implementation of the selected remedial action.

This report is a continuation of the assessment made for Title I requirements and has been prepared by FB\&DU. In connection with the field studies made in 1976, the oak Ridge National Laboratory (ORNL) at oak Ridge, Tennessee, under separate agreement with DOE, provided measurements of the radioactivity concentrations in the soil and water samples and gamma surveys. (3) The EPA staff provided the results of radiation surveys they previously had made at the Grand Junction site. 
The specific scope requirements of the Title I assessment as given in the contract may include but are not limited to the following:

(a) Preparation of an engineering assessment report for each site, and preparation of a comprehensive report suitable for submission to the Congress on reasonable remedial action alternatives and their estimated cost.

(b) Determination of property ownership in order to obtain release of Federal Government and A-E liability for performance of engineering assessment work at both inactive millsites and privately owned structures.

(c) Preparation of topographic maps of millsites and other sites to which tailings and other radioactive materials might be moved.

(d) Performance of core drillings and radiometric measurements ample to determine volumes of tailings and other radium-contaminated materials.

(e) Performance of radiometric surveys, as required, to determine areas and structures requiring cleanup or decontamination.

(f) Determination of the adequacy and the environmental suitability of sites at which mill tailings containing radium could be disposed, and once such sites are identified, performance of evaluations and estimation of the costs involved.

(g) Performance of engineering assessments of structures where uranium mill tailings have been used in off-site non-construction applications to arrive at recommendations and estimated costs of performing remedial action.

(h) Evaluation of various methods, techniques, and materials for stabilizing uranium mill tailings to prevent wind and water erosion, to inhibit or eliminate radon exhalation, and to minimize maintenance and control costs.

(i) Evaluation of availability of suitable fill and stabilization cover materials that could be used.

(j) Evaluation of radiation exposures of individuals and nearby populations resulting from the inactive uranium millsite, with specific attention to: 
(1) Gamma radiation

(2) Radon

(3) Radon daughter concentrations

(4) Radium and other naturally occurring radioisotopes in the tailings

(k) Review of existing information about site hydrology and meteorology.

(1) Evaluation of recovering residual values, such as uranium and vanadium in the tailings and other residues on the sites.

(m) Performance of demographic and land use studies. Investigation of community and area planning, and industrial and growth projections.

(n) Evaluation of the alternative corrective actions for each site in order to arrive at recommendations, estimated costs, and socioeconomic impact based on population and land use projections.

(o) Preparation of preliminary plans, specifications, and cost estimates for alternative corrective actions for each site.

Not all of these items received attention at the Grand Junction site.

\section{I.2 SITE DESCRIPTION}

1.2.1 Location and Topography

The Grand Junction mill and tailings site is a 67.68-acre tract located on the south side of the city of Grand Junction, Colorado. It is on the north bank of the colorado River and adjacent to the industrial center of the city. The site and its relationship to the surrounding area are shown in the aerial photograph in Figure 2-1. The city and the site are located in Grand Valley, a valley of the Colorado River near its confluence with the Gunnison River. The city is surrounded by arid and largely unvegetated mesas and mountains to the north and west. To the south and east, the mountains are more rugged and vegetated. The elevation of the site is about 4.590 ft above sea level. 
1.2.2 Ownership and History of Miling operations and

processing

A beet sugar refinery was originally located at the site, which consisted of about 200 acres. In 1951, Climax Uranium Company, a division of American Metals Climax (now known as AMAX, Inc.), started milling operations at the site. About 85 acres have since been developed into an industrial park, about 40 acres deeded to the state of colorado as a repository for a remedial action program in the Grand Junction area, and about 10 acres sold to a private citizen. The mill was shut down in March 1970. The 61.13 acres on which the tailings pile is located are presently owned by sand Extraction company of Moab, Utah, while the 6.55 acres of the mill area are owned by BESS Investments of Grand Junction, Colorado.

During the 19-yr period of operation, 2.2 million tons of ore were processed, of which 1.9 million tons of tailings remain. Ore averaging $0.28 \% \mathrm{U}_{3} \mathrm{O}_{8}$ and $1.41 \% \mathrm{~V}_{2} \mathrm{O}_{5}$ was delivered to the mill from all parts of the Uravan mineral belt area. About 10,000 tons of ore have recently been removed from the ore storage area for processing.

1.2.3 Present Condition of the site

There is one large tailings pile of 61.13 acres on the site. It has been stabilized with a 6-in. earth cover and vegetated with grasses. An earthen dike with mill debris used as riprap protects the pile from erosion by the Colorado River. The site is partially enclosed with a chainlink fence. There are four remaining mill buildings on the site. Beneath the tailings are found many remnants of the milling operations: an old 30-in.-diameter wood stave waterline (inactive) with an open access structure on the surface of the pile; a nonoperational sewer line; a city waterline which has been shut off; three settling ponds filled with debris, tailings, and stabilization cover; and the mill stack used during operations. In the northeast corner of the site there is an abandoned sewage treatment plant, where a few structures and concrete foundations remain. Figure $2-4$ is a descriptive map of the site, and a cross-section of the pile is presented in Figure 2-5.

Battelle Pacific Northwest Laboratories has graded the western portion of the site and is conducting tailings stabilization studies on the site at the present time.

\section{2 .4 Tailings and Soil Characteristics}

several types of materials make up the Grand Junction tailings pile: uranium and vanadium tailings, rubble, and contaminated earth. The tailings consist of grey, finely-ground sands and purple slimes. Bulk densities of the materials range between 70.1 and $109.9 \mathrm{lb} / \mathrm{ft}^{3}$. The amounts of materials on 
the site are listed in Table 2-1. The tailings rest on gravel and clay that have been deposited by the Colorado River.

1.2.5 Geology, Hydrology, and Meteorology

The Grand Junction tailings and millsite are located on the modern flood plain of the colorado River. A relatively thin (200-ft) section of remaining Mancos shale underlies the unconsolidated riverbed deposits and acts as a barrier to the downward and upward migration of ground water. The bedrock strata dip 5 to 10 deg toward the southwest. A simplified stratigraphic column is shown in Figure 2-6.

The flowing surface waters adjacent to or near the site consist of the Colorado River on the south side of the pile, a drainage ditch along the eastern side, and several man-made facilities associated with earlier operations at the site. The Colorado River at Grand Junction has a long history of flooding. During an intermediate regional flood (100-yr flood) or a more severe standard project flood, the tailings pile would be an island surrounded by flood waters. Only the northernmost edge of the pile would be flooded, although much of the tailings would be saturated by associated unconfined ground water rising as much as $10 \mathrm{ft}$ into the pile.

Contamination of surface water near the piles could occur by physical transport of the tailings by overland runoff and by seepage from the piles. The potential for water erosion of the tailings has been reduced by contouring the pile, applying a 6-in. Cover of soil, and seeding the surface. The overland flow on the piles is limited almost entirely to the precipitation that actually falls on the pile.

The unconfined aquifers in the Grand Junction area consist of waters within the alluvial deposits of the Colorado River and its tributaries, within the terrace deposits, within weathered rocks and soils, and in the Mancos Shale. There is little potential for seepage of precipitation through the pile and into the unconfined ground waters beneath the pile. The water table associated with the colorado River fluctuates several feet during the year and may saturate some of the lowermost tailings. ongoing contamination due to water table fluctuations would be carried by unconfined ground waters into the Colorado River and eventually would be diluted. The Mancos shale acts as a virtually impermeable layer that confines the waters of the Dakota Sandstone and other stratigraphically lower aquifers.

Meteorology records from the Grand Junction airport show that the annual precipitation averages $9 \mathrm{in.}$, with the heaviest rainstorms occurring from May through october. The strongest winds are generally from the south or southwest. Prevailing winds at the tailings site follow the colorado River valley, generally east and west. 
1.3 RADIOACTIVITY AND POLLUTANT IMPACTS ON THE ENVIRONMENT

About $85 \%$ of the total radioactivity originally in uranium ore remained in the tailings after removal of the uranium. The principal environmental radiological impact and associated health effects arise from the $230_{\mathrm{Th}}, 226_{\mathrm{Ra}}, 222 \mathrm{Rn}$, and $222_{\mathrm{Rn}}$ daughters contained in the uranium tailings. Although these radionuclides occur in nature, their concentrations in tailings material are several orders of magnitude greater than their average concentrations in the earth's crust. Because of the chemical treatments they have experienced, they appear to be more soluble and, therefore, more mobile.

1.3.1 Radiation Exposure Pathways, Contamination Mechanisms, and Background Levels

The major potential environmental routes of exposure to man are:

(a) Inhalation of $222 \mathrm{Rn}$ and its daughter products, resulting from the continuous radioactive decay of $226_{\mathrm{Ra}}$ in the tailings. Radon is a gas which diffuses from the piles. The principal exposure results from inhalation of the $222_{R n}$ daughters. This exposure affects the lungs. For this assessment, no criteria have been established for radon concentrations in air. However, the pathway for radon and radon daughters accounts for the major portion of the exposure to the population.

(b) External whole-body gamma exposure directly from radionuclides in the piles.

(c) Inhalation and ingestion of windblown tailings. The primary health effect relates to the alpha emitters $230_{\mathrm{Th}}$ and $226_{\mathrm{Ra}}$, each of which causes exposure to the bones and lungs.

(d) Ingestion of ground and surface water contaminated with radioactive elements (primarily $226_{\mathrm{Ra}}$ ) and other toxic materials.

(e) Contamination of food through uptake and concentration of radioactive elements by plants and animals is another pathway that can occur: however, this pathway was not considered in this study.

1.3.1.1 Radon Gas Diffusion and Transport

Measurements of radon flux from the tailings made in $1977(2)$ ranged from 25 to $656 \mathrm{pCi} / \mathrm{m}^{2}-\mathrm{s}$. Measurements of radon flux made in August 1980 ranged between 90 and $1.340 \mathrm{pci} / \mathrm{m}^{2}-\mathrm{s}$, 
with a mean flux on the tailings pile estimated to be about $550 \mathrm{pCi} / \mathrm{m}^{2}-\mathrm{s}$. At the times of measurements, the surface soil was dry and the weather was fair and warm. The radon flux from the state repository was measured and the average flux estimated to be about $16 \mathrm{pCi} / \mathrm{m}^{2}-\mathrm{s}$. Radon flux depends principally on radium content of tailings; however, it also varies considerably because of moisture, soil characteristics, and climatological conditions.

Short-term radon measurements were performed by FB\&DU in 1976 with continuous radon monitors supplied by ERDA at eight locations in the vicinity of the Grand Junction tailings pile. The locations and values of the radon measurements including background are shown in Figure 3-4. The highest outdoor radon concentration was measured on the northwest corner of the pile. The radon concentration at this location averaged $59 \mathrm{pCi} / 1$ for a 24-hr period. At a location $0.33 \mathrm{mi}$ west-northwest of the tailings, a $24-\mathrm{hr}$ average radon concentration of $2.6 \mathrm{pCi} / 1$ was measured. The background radon concentration used in this assessment was $0.8 \mathrm{pCi} / 1$, taken from measurements conducted in $1967(4)$ and $1974-1975 .(5)$

\subsubsection{Direct Gamma Radiation}

Natural background values of direct gamma radiation in the Grand Junction area range between 8 and $12 \mu \mathrm{R} / \mathrm{hr}$, with an average of $11 \mu \mathrm{R} / \mathrm{hr}$, as measured $3 \mathrm{ft}$ above ground with an energy-compensated Geiger Mueller detector.(3) Above the surface of the tailings pile, gross gamma radiation rates ranged from 60 to $350 \mathrm{\mu R} / \mathrm{hr}$. Gross gamma radiation rates on the former milisite ranged from two times background to $300 \mu \mathrm{R} / \mathrm{hr}$. on land north of the mill building (land owned by colorado West Improvement, Inc.), the gamma radiation rates ranged as high as 14 times background (150 $\mathrm{\mu R} / \mathrm{hr})$, indicating soil contamination. This area north of the mill building is included in the site decontamination activities described in Chapter 9.

\subsubsection{Windolown Contaminants}

Prevailing winds in the area follow the colorado River Valley and are from the west, northwest, and east to southeast. concentrations of $226_{\mathrm{Ra}}$ in surface soil samples and an EPA gamma survey $(6)$ were used to determine the extent of windblown tailings. A background iso-exposure line marking the extent of residual windblown tailings as determined by the $E P A$ is illustrated in Figure 3-11.

During the 1977 engineering assessment, surface soil samples were taken in the vicinity of the tailings pile. samples taken about 650 to 700 yd toward the north, west, and east of the site contained 4,9 , and 40 times the average background concentrations of $226 \mathrm{Ra}$, respectively. These elevated levels of $226 \mathrm{Ra}$ were outside the range of windblown tailings as determined by the gamma surveys. 
During the 1980 field work the extent of windblown contamination was estimated with a lead-shielded scintillometer. The approximate boundary of the area contaminated in excess of $5 \mathrm{pCi} / \mathrm{g}$ above background $226_{\mathrm{Ra}}$ is shown in Figure $3-12$.

1.3.1.4 Ground and Surface Water Contamination

Four water samples taken in 1976 from flowing water in the vicinity of the pile contained $226_{\text {Ra }}$ concentrations ranging from 0.06 to $0.9 \mathrm{pci} / 1 .(3)$ These values were lower than the limits of the EPA Interim Primary Drinking water Regulations for radionuclides. (7) However, stagnant water from the tailings and mill areas contained $226_{\mathrm{Ra}}$ concentrations of 3.2 to $81.9 \mathrm{pCi} / 1$.

1.3.1.5 Soil Contamination

The leaching of radium from the tailings into the subsoil ranges from 2 to 5 ft and generally extends to about 3 ft before reaching twice the average background radium concentration in the soil. The average background concentration of $226 \mathrm{Ra}$ in the soil from western colorado is about $1.5 \mathrm{pCi} / \mathrm{g} .(3)$ In the northeast corner of the pile the contamination decreases to 3 times background 3 ft below the tailings-soil interface.

\subsubsection{Remedial Action Criteria}

For the purpose of carrying out the original engineering assessment studies, (2) provisional criteria provided by the EPA were used. The criteria were in two categories, and applied either to structures with tailings present or to land areas to be decontaminated. For structures, the indoor radiation level below which no remedial action was indicated was considered to be an external gamma radiation level of less than $0.05 \mathrm{mR} / \mathrm{hr}$ above background and a radon daughter concentration of less than 0.01 WL above background. Land could be released for unrestricted use if the external yamma radiation levels were less than $10 \mu \mathrm{R} / \mathrm{h} x$ above background. When cleanup was necessary, residual radium content of the soil after remedial action should not exceed twice background in the area.

Since enactment of the Uranium Mill Tailings Radiation Control Act of 1978 (PL 95-604), which was effective November 8, 1978, the EPA has published interim (45 FR 27366) and proposed (46 FR 2556) standards for structures and open lands. These standards establish the indoor radon daughter concentration, including background, below which no remedial action is indicated at $0.015 \mathrm{WL}$. The indoor gamma radiation limit is $0.02 \mathrm{mR} / \mathrm{hr}$ above background.

For open land, remedial action must provide reasonable assurance that the average concentration of $226_{\mathrm{Ra}}$ attributable to residual radioactive material from any designated processing 
site in any 5-cm thickness of soils or other materials within 1 Et of the surface, or in any $15-\mathrm{cm}$ thickness below $1 \mathrm{ft}$, shall not exceed $5 \mathrm{pci} / \mathrm{g}$.

Envixonmental standards have been proposed by the EPA (46 FR 2556). for the disposal of residual radioactive materials from inactive uranium processing sites. These standards require that disposal of residual radioactive materials be conducted in a way which provides a reasonable assurance that for at least 1,000 yr following disposal:

(a) The average annual release of $222_{\mathrm{Rn}}$ from the disposal site to the atmosphere by residual radioactive materials will not exceed $2 \mathrm{pCi} / \mathrm{m}^{2}-\mathrm{s}$.

(b) Substances released from residual radioactive materials after disposal will not cause:

(1) the concentrations of those substances in any underground source of drinking water to exceed the level specified below, * or

(2) an increase in the concentrations of those substances in any underground source of drinking water where the concentrations of those substances prior to remedial action exceed the levels specified below for causes other than residual radioactive materials.*

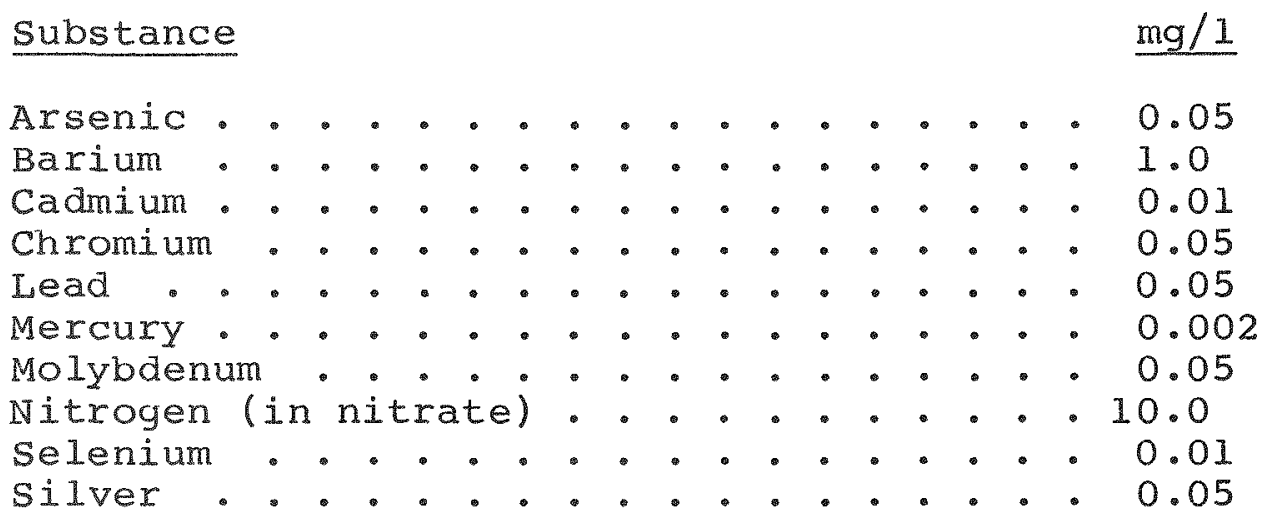

\footnotetext{
*These requirements apply to the dissolved portion of any substance listed above at any distance greater than $1.0 \mathrm{~km}$ from a disposal site that is part of an inactive processing site, or greater than $0.1 \mathrm{~km}$ if the disposal site is a depository site.
} 
Substance

$\underline{p C i / 1}$

Combined $226_{\mathrm{Ra}}$ and $228_{\mathrm{Ra}}$. . . . . . . 5.0

Gross alpha particle activity

(including $226_{\mathrm{Ra}}$ but excluding

radon and uranium)........... 15.0

Uranium . . . . . . . . . . . . 10.0

(c) Substances released from the disposal site after disposal will not cause the concentration of any harmful dissolved substance in any surface waters to increase above the level that would otherwise prevail.

Since the passage of PL 95-604, the NRC has published final regulations for uranium mill tailings licensing in the Federal Register (45 FR 65521). They include the requirement that the stabilization method must include an earth cover of at least a 3-m thickness and sufficient to reduce the radon emanation rate from the tailings to $2 \mathrm{pCi} / \mathrm{m}^{2}-\mathrm{s}$ above background. In addition, seepage of materials into ground water should be reduced by design to the maximum extent reasonably achievable.

While these standards may undergo further limited revisions, they will not likely experience changes that would significantly alter the nature of the remedial actions or their estimated costs. Therefore, the interim and proposed standards as indicated above form the basis for determining required remedial actions and their associated costs.

\subsubsection{Potential Health Impact}

Radon gas exhalation from the pile and the subsequent inhalation by man of radon daughters account for most of the total dose to the population from the Grand Junction site under present conditions. The gamma radiation exposure from the pile is very small since there are very few persons who live or work within $0.2 \mathrm{mi}$ of the piles, where yamma radiation is above background.

Gamma radiation can be reduced effectively by shielding with any dense material. However, experience has shown that it is very difficult to control the movement of radon gas through porous materials. Once released from the radium-bearing minerals in the tailings, the gaseous radon diffuses by the path of least resistance to the surface. The radon has a halfIife of about 4 days, and its daughter products are solids. Therefore, part of the radon decays en route to the surface and leaves daughter products within the tailings pile. If the diffusion path can be made long enough, then, theoretically, virtually all of the radon and its daughter products will have decayed before escaping to the atmosphere. Calculations using the theoretical techniques of Kraner, Schroeder, and Evans(8) earlier indicated that $13 \mathrm{ft}$ of earth cover would be required 
to reduce the radon diffusion from the Grand Junction tailings by $95 \%$. Later experimental work (9) has demonstrated that 2 to 3 ft of compacted clay may be sufficient to reduce radon flux to less than $2 \mathrm{pCi} / \mathrm{m}^{2}-\mathrm{s}$, assuming the continued integrity of the clay cover.

The health significance to man of long-term exposure to radiation is a subject that has been studied extensively for many years. Since the end results of long-term exposure to low-level radiation may be diseases such as lung cancer or leukemia, which are also attributable to many other causes, the determination of specific cause in any given case becomes very difficult. Therefore, the usual approach to evaluation of the health impact of low-level radiation exposures is to make projections from observed effects of high exposures on the premise that the effects are linear. A considerable amount of information has been accumulated on the high incidence of lung cancer in uranium miners and others exposed to radon and its daughters in mine air. This provides a basis for calculating the probable health effects of low-level exposure to large populations. (The term "health effect" refers to an incidence of disease; for radon daughter exposure, a health effect is a case of lung cancer.) This is the basis of the health effects calculated in this report. It should be recognized, however, that there is a large degree of uncertainty in such projections. Among the complicating factors is the combined effect of radon daughters with other carcinogens. As an example, the incidence of lung cancer among uranium miners who smoke is far higher than can be explained on the basis of either smoking or the radiation alone.

The risk estimators used in this report are given in the report of the National Acaderny of Sciences Advisory Committee on the Biological Effects of Ionizing Radiation (BEIR-III report).(10) This report presents risk estimators for lung cancer derived from epidemiological studies of both uranium miners and fluorspar miners. The average of the age-dependent absolute risk estimators for these two groups as applied to the population at large is 150 cancers per year per $10^{\circ}$ person-WLM of continuous exposure, assuming a lifetime plateau to age 75 . The term WLM means working level months, or an exposure to a concentration of one working level of radon daughter products in air for $170 \mathrm{hr}$, which is a work-month. A working level (WL) is a unit of measure of radon daughter products which recognizes that the several daughter elements are frequently not in equilibrium with each other or with the parent radon. Because of the many factors that contribute to natural biological variability and of the many differences between exposure conditions in mines and residences, this estimator (150 cancer cases per year per $10^{6}$ person-WLM of continuous exposure) is considered to have an uncertainty of a factor of about 3. Another means of expressing $r i s k$ is the relative risk estimator, which yields risk as a percentage increase in health effects per $10^{6}$ person-WLM of continuous exposure. However, this 
method has been shown to be invalid(11) and is not considered in this assessment.

For the purpose of this engineering assessment, it was assumed that about $50 \%$ equilibrium exists inside structures between radon and its daughter elements resulting in the following conversion factors:

$$
1 \mathrm{pCi} / 1 \text { of } 222 \mathrm{Rn}=0.005 \mathrm{WL}
$$

For continuous exposure:

$$
0.005 \mathrm{WL}=0.25 \mathrm{WLM} / \mathrm{Yr}
$$

On the basis of predictions of radon concentrations in excess of the background value under present conditions, it was calculated that the average lung cancer risk attributable to radon from the pile in the area within $6 \mathrm{mi}$ of the Grand Junction site is $2.2 \times 10^{-6}$ per person per year, or less than 28 of the average lung cancer risk due to all causes for Colorado residents $\left(1.8 \times 10^{-4}\right)$. (12) For those within 0.75 mi of the pile, the average lung cancer risk due to the pile is $1.5 \times 10^{-5}$ per person per year, or about $50 \%$ of the cancer risk due to all causes.

The 25-yr health effects were calculated for three population projections using the present population $(62,670$ in the 0 - to 6-mi area, and 4,214 in the 0-to $0.75-\mathrm{mi}$ area). The results for pile-induced radon and background radon for the two areas ( 0 to $6 \mathrm{mi}$ and 0 to $0.75 \mathrm{mi}$ ) are as follows:

25-Year Cumulative Health Effects within 6 Miles of Edge of Pile Projected Population Growth Pile-Induced RDC Background RDC

Constant $0.8 \%$ growth rate $6.3 \%$ declining growth rate* $10 \%$ declining growth rate*
3.9

$6 \cdot 1$

$8 \cdot 5$
53

83

114

25-Year Cumulative Health Effects within 0.75 Mile of Edge of Pile

projected Population Growth

Constant $0.8 \%$ growth rate $6.3 \%$ declining growth rate* $10 \%$ declining growth rate*
Pile-Induced RDC

Background RDC

1.8

2.8

$3 \cdot 8$
3.4

5.4

7.5

* Declines linearly from its initial value to zero in 25 yr and remains constant at zero thereafter. 
Pile-induced radon daughter health effects are approximately $7 \%$ and $50 \%$ of the background radon daughter health effects for the 0- to 6-mi and 0 - to 0.75-mi areas, respectively. The exposure and consequent risk will continue as long as the radiation source remains in its present location and condition.

\subsubsection{Nonradioactive Pollutants}

There are other potentially toxic materials in the tailings. Chemical analyses of tailings samples from drill holes on the Grand Junction tailings pile showed selenium at about 3 ppm; lead, chromium, and barium between 25 and 130 ppm; arsenic at $14 \mathrm{ppm}$; and vanadium as high as 2,000 ppm. Fourteen samples of surface waters in the area surrounding the Grand Junction tailings pile contained selenium in concentrations above the limits of the EPA Interim Primary Drinking Water Regulations. However, there was no consistent degradation of the surface waters as they flowed by the tailings pile. The selenium content of the colorado River ranged from 4 to 6 times the maximum acceptable level of selenium upstream and downstream from the tailings. The Colorado River samples also contained above-recommended levels of iron. Consequently, removal of the Grand Junction tailings might not noticeably upgrade the nonradioactive environmental pollutant quality of the Colorado River.

\subsection{SOCIOECONOMIC AND LAND USE IMPACTS}

The area near the tailings is characterized by five land use patterns: industrial, vacant, agricultural, recreational, and residential. The area adjacent to the tailings on the north is industrial land or is in transition from vacant/agricultural uses to industrial uses. An industrial park is being developed by Colorado West Improvement, Inc., on land immediately north of the site between the D\&RGW Railroad and the tailings. There are residential areas northwest of the tailings and south of the tailings on the opposite bank of the Colorado River.

As the industrial park continues to expand, there will be increased pressure to use the site for industrial purposes. There will be pressure to develop the southern section of the site as part of the Colorado River Parkway, a greenbelt area for recreation, preservation, and restoration.

Most of the land in the area is privately owned. The land on which the tailings are located is listed in the Mesa county Assessor's records at $\$ 33 /$ acre (estimated market value). The land on which the mill buildings are located is listed at

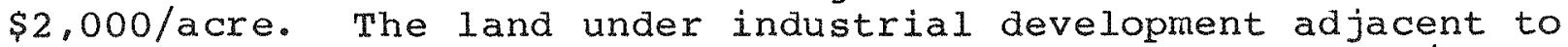
the tailings site is valued at between $\$ 2,000$ and $\$ 10,000 / a c r e$, while the residential land northwest of the tailings site is valued at $\$ 8,000 / a c r e$. In general, the market value of land 
in the vicinity of the tailings site ranges from $\$ 2,000$ to $\$ 12,700 /$ acre.

\subsection{RECOVERY OF RESIDUAL VALUES}

Samples of tailings obtained during this study were composited and analyzed. The composited sample contained $0.018 \% \mathrm{U}_{3} \mathrm{O}_{8}$. Estimates of the Grand Junction tailings from AEC records show an average of $0.017 \% \mathrm{U}_{3} \mathrm{O}_{8}$. The latter value was used for evaluating the economic viability of reprocessing the tailings.

There are five factors that can be employed to evaluate whether reprocessing the Grand Junction tailings to extract residual uranium and other mineral values would be practicable:

(a) The amount of tailings present

(b) Concentrations of residual values

(c) Projected recovery

(d) Current market price of recovered values

(e) Proximity to processing mills.

Three principal alternatives for the reprocessing of the Grand Junction tailings were examined:

(a) Heap leaching

(b) Treatment at an existing mill

(c) Reprocessing at a new conventional mill constructed for tailings reprocessing.

The cost of the uranium recovered would be about $\$ 200 / 1 \mathrm{~b}$ and $\$ 150 / 1$ b of $\mathrm{U}_{3} \mathrm{O}_{8}$ by heap leach and by conventional plant processes, respectively. The spot market price for uranium was $\$ 25 / 1 b$ early in 1981. Therefore, reprocessing the tailings for uranium recovery appears not to be economically attractive at present.

Although vanadium tailings contain vanadium, gold, and silver, the small quantity of these tailings makes economic recovery of these resources doubtful.

\subsection{MILL TAILINGS STABILIZATION}

Investigations of methods of stabilizing uranium mill tailings piles from wind and water erosion have indicated a variety of deficiencies among the methods. Chemical stabilization (treatment of the tailings surface) has been successful only for temporary applications and is thus viewed as inadequate 
for currently proposed disposal criteria. Volumetric chemical stabilization (solidifying the bulk of the tailings) techniques appear to be costly and of questionable permanence. Physical stabilization (emplacement of covers over the tailings) methods using soil, clay, or gravel have been demonstrated on a laboratory scale to be effective in stabilizing tailings. Artificial cover materials are attractive but have the disadvantage of being subject to degradation by natural and artificial forces. Vegetative stabilization (establishment of plant growth) methods are effective in limiting erosion. However, where annual precipitation is less than about 10 in., soil moisture content may be inadequate to ensure viability of the plant life.

Migration of contaminants into ground water systems must be limited under the NRC and EPA criteria. control of water percolating through the tailings can be accomplished by stabilizing chemically, by physically compacting the cover material, and by contouring the drainage area and tailings cover surface. Isolation of the tailings from underlying ground water systems can be accomplished by lining a proposed disposal site with a natural liner or artificial impermeable membranes.

Several materials have been identified which sufficiently retard radon migration that the radon flux is substantially reduced, on a laboratory scale. Unfortunately, no large-scale application has been undertaken which would demonstrate that these materials satisfy all of the technical criteria in the EPA-proposed standards and NRC regulations for licensing of uranium mills. However, extensive investigations of these questions continue in the Technology Development program of the Uranium Mill Tailings Remedial Actions project office in Albuquerque, New Mexico.

In view of findings from stabilization research, it appears that physical stabilization of tailings with $3 \mathrm{~m}$ of well-engineered cover material may be sufficient to appropriately stabilize tailings at their disposal site to meet NRC regulations.

\subsection{OFF-SITE REMEDIAL ACTION}

As a result of ongoing monitoring and surveys of properties in the Grand Junction area, the Colorado Department of Health has identified over 6,100 properties away from the tailings site where tailings have been used. Many of these properties have been or are being decontaminated in conjunction with the Grand Junction remedial action program authorized under separate legislation. It is possible that half of these decontaminated properties will not satisfy remedial action standards proposed by the EPA. Thus, most of the off-site tailings use locations will require decontamination under PL 95-604. 


\subsection{DISPOSAL SITE SELECTION}

In this update, seven of the alternative remedial action options include moving the Grand Junction tailings to a disposal site. The corresponding seven disposal sites were selected after consultation with local, state of colorado, and federal. agencies; concerned individuals; and personnel in industry. Each site was evaluated on the bases of hydrology, meteorology, geology, ecology, economics, and proximity to population centers. The seven sites were selected from a total of 22 sites considered initially. Since the responsibility for disposal site selection lies primarily with the Federal Government, with input from the state, the disposal sites evaluated in this report must be considered only as tentative.

The relative locations of the sites listed in Table $1-2$ as options II through VIII are shown in Figure 8-1. In each of these options, surface material would be removed, as appropriate, from the disposal area and stockpiled. A retaining dike and diversion ditches would be constructed if necessary. The tailings would be emplaced, contoured, and covered with $3 \mathrm{~m}$ of soil. The surface would be covered with $0.3 \mathrm{~m}$ of riprap or vegetation established for erosion control, and the entire site would be fenced.

\subsection{REMEDIAL ACTIONS AND COST-BENEEIT ANALYSES}

\subsubsection{Remedial Action Options}

The remedial action options examined include stabilization of the tailings pile in its present location and in its present configuration, and removal of all radioactive materials. including contaminated material in the state repository. to an area where these materials could be isolated from the public. The options for which cost estimates were made include stabilization on the present site with $3 \mathrm{~m}$ of cover material and the removal of tailings to one of seven possible locations. The options are summarized in Table $1-2$.

The basis for comparison, from which the cost effectiveness of remedial alternatives can be judged, is the present condition of the site with no remedial action.

Option I represents remedial action activities to stabilize the pile more completely in its present location with the addition of $3 \mathrm{~m}$ of cover and the construction of additional dike protection. Erosion of the tailings would be controlled more completely and radon exhalation would be reduced to not more than $2 \mathrm{pCi} / \mathrm{m}^{2}-\mathrm{s}$ above background. The site would be available for restricted use only.

seven sites were evaluated for possible disposal of tailings, and cost estimates for disposal at each site were made. Their locations are given in Figure 8-1 and Table 8-1. 
The disposal site with the lowest estimated costs, Whitewater Hill, is closest to the tailings pile. Use of the site would involve negotiations with federal and local government officials. Tailings could be disposed of either in the sanitary landfill or in a canyon at the site.

Two of the sites are located in vacant, arid, and unusable land located between the Book Cliffs and the Government Highline Cana1, north of Grand Junction. The Grasso Mine Road and Indian Wash sites have the advantage of isolation but the disadvantage of the necessity of hauling the tailings through populated areas of the city.

The East Orchard Mesa site is the most remote of the sites and has an abundant supply of excellent cover material. It would be sheltered from winds and erosion, and truck traffic would be through less populated areas.

An unspecified site near DeBeque is assumed to have the advantage of being of sufficient size to accommodate the tailings from both Grand Junction and the two piles located at Rifle, Colorado. Rail transportation is proposed for this location, which is approximately midway between Grand Junction and Rifle. The same railroad line borders all three sites and runs through the valley in which DeBeque is located.

\subsubsection{Cost-Benefit Analyses}

As summarized in Table 9-1, the total costs (excluding off-site remedial action costs) for the eight remedial action options vary from about $\$ 10.2$ million to about $\$ 41.9$ million. Each of these options would have associated health and monetary benefits. The options are identified by number in Paragraph 1.1.

The number of cancer cases avoided per million dollars expended for each option is given in Figure 9-3. The curves in Figure 9-3 indicate an increase in health benefit-cost ratio with time due to the greater reduction in population exposure over longer periods of time as a result of remedial action. The potential cancer cases avoided for each option and the cost per potential cancer case avoided are given in Table 9-2. 
TABLE 1-1

SUMMARY OF CONDITIONS NOTED AT TIME OF 1980 SITE VISITS

\begin{tabular}{|c|c|c|c|c|c|c|c|c|c|c|}
\hline $\begin{array}{l}\text { Cor } \\
\text { of } \\
\text { Ta }\end{array}$ & $\begin{array}{l}\text { dition } \\
\text { ings } a \\
\end{array}$ & $\begin{array}{l}\text { Condition } \\
\text { of } \\
\text { Structures } \\
\text { On Site } \\
\end{array}$ & $\begin{array}{l}\text { Mi11 } \\
\text { Housing } \\
\end{array}$ & $\begin{array}{l}\text { Adequate } \\
\text { Fencing, } \\
\text { Posting, } \\
\text { Security }\end{array}$ & $\begin{array}{l}\text { Property } \\
\text { Close to } \\
\text { River or } \\
\text { Stream } \\
\end{array}$ & $\begin{array}{l}\text { Houses or } \\
\text { Industry } \\
\text { within } \\
0.5 \mathrm{Mi} \\
\end{array}$ & $\begin{array}{l}\text { Evidence } \\
\text { of Wind } \\
\text { or Water } \\
\text { Erosion } \\
\end{array}$ & $\begin{array}{l}\text { Possible } \\
\text { Water } \\
\text { Contam- } \\
\text { ination } \\
\end{array}$ & $\begin{array}{l}\text { Tailings } \\
\text { Removed } \\
\text { for } \\
\text { Private } \\
\text { Use } \\
\end{array}$ & $\begin{array}{l}\text { Other } \\
\text { Hazards } \\
\text { On Site }\end{array}$ \\
\hline \multicolumn{11}{|l|}{ ARIZONA } \\
\hline Monument Valley & $\mathrm{U}$ & $\mathbf{R}$ & $\mathbf{N}$ & No & No & Yes & Yes & No & Yes & No \\
\hline Tuba City & $\mathrm{U}$ & $\mathrm{PR}-\mathrm{UO}$ & $\mathrm{E}-\mathrm{P}$ & No & No & Yes & Yes & No & No & Yes \\
\hline \multicolumn{11}{|l|}{ COLORADO } \\
\hline Durango & $P$ & $\mathrm{PR}-\mathrm{UO}$ & $\mathbf{N}$ & Yes & Yes & Yes & Yes & No & Yes & Yes \\
\hline Grand Junction & $S$ & $P R=0$ & $\mathbf{N}$ & Yes & Yes & Yes & Yes & Yes & Yes & No \\
\hline Gunnison & $\mathbf{S}$ & $\mathrm{B}-\mathrm{O}$ & $\mathrm{N}$ & No & Yes & Yes & No & Yes & No & No \\
\hline Maybel1 & $\mathbf{S}$ & $\mathrm{R}$ & $\mathbf{N}$ & Yes & No & No & Yes & No & No & No \\
\hline Naturita & RMS & $\mathrm{PR}-\mathrm{O}$ & $\mathbf{N}$ & Yes & Yes & Yes & Yes & Yes & No & No \\
\hline New Rifle & $\mathrm{P}$ & $M-O$ & $\mathrm{~N}$ & Yes & Yes & Yes & Yes & Yes & No & No \\
\hline Old Rifle & $S$ & $\mathrm{PR}-\mathrm{UO}$ & $\mathbf{N}$ & Yes & Yes & Yes & No & Yes & Yes & No \\
\hline Slick Rock (NC) & $\mathbf{S}$ & $\mathrm{R}$ & $\mathrm{N}$ & Yes & Yes & Yes & Yes & Yes & No & No \\
\hline Slick Rock (UCC) & $S$ & $\mathrm{R}$ & $\mathrm{E}-\mathrm{P}$ & Yes & Yes & Yes & No & Yes & No & No \\
\hline \multicolumn{11}{|l|}{ IDAHO } \\
\hline Lowman & $\mathrm{U}$ & $\mathrm{R}$ & $\mathrm{N}$ & No & Yes & Yes & Yes & Yes & Yes & No \\
\hline \multicolumn{11}{|l|}{ NEW MEXICO } \\
\hline Ambrosia Lake & $\mathrm{U}$ & $\mathrm{PR}-\mathrm{O}$ & $\mathbf{N}$ & No & No & No & Yes & No & No & No \\
\hline Shiprock & $S$ & $\mathrm{PR}-\mathrm{O}$ & $\mathrm{N}$ & Yes & Yes & Yes & No & Yes & Yes & No \\
\hline \multicolumn{11}{|l|}{ NORTH DAKOTA } \\
\hline Belfield & $\mathrm{R}$ & $\mathrm{PR}-\mathrm{O}$ & $\mathbf{N}$ & No & No & Yes & No & No & No & No \\
\hline Bowman & $\mathrm{R}$ & $\mathrm{R}$ & $\mathrm{N}$ & No & No & No & No & No & No & No \\
\hline \multicolumn{11}{|l|}{ OREGON } \\
\hline Lakeview & $S$ & $B-O$ & $\mathbf{N}$ & Yes & No & Yes & Yes & No & No & No \\
\hline
\end{tabular}


TABLE 1-1 (cont)

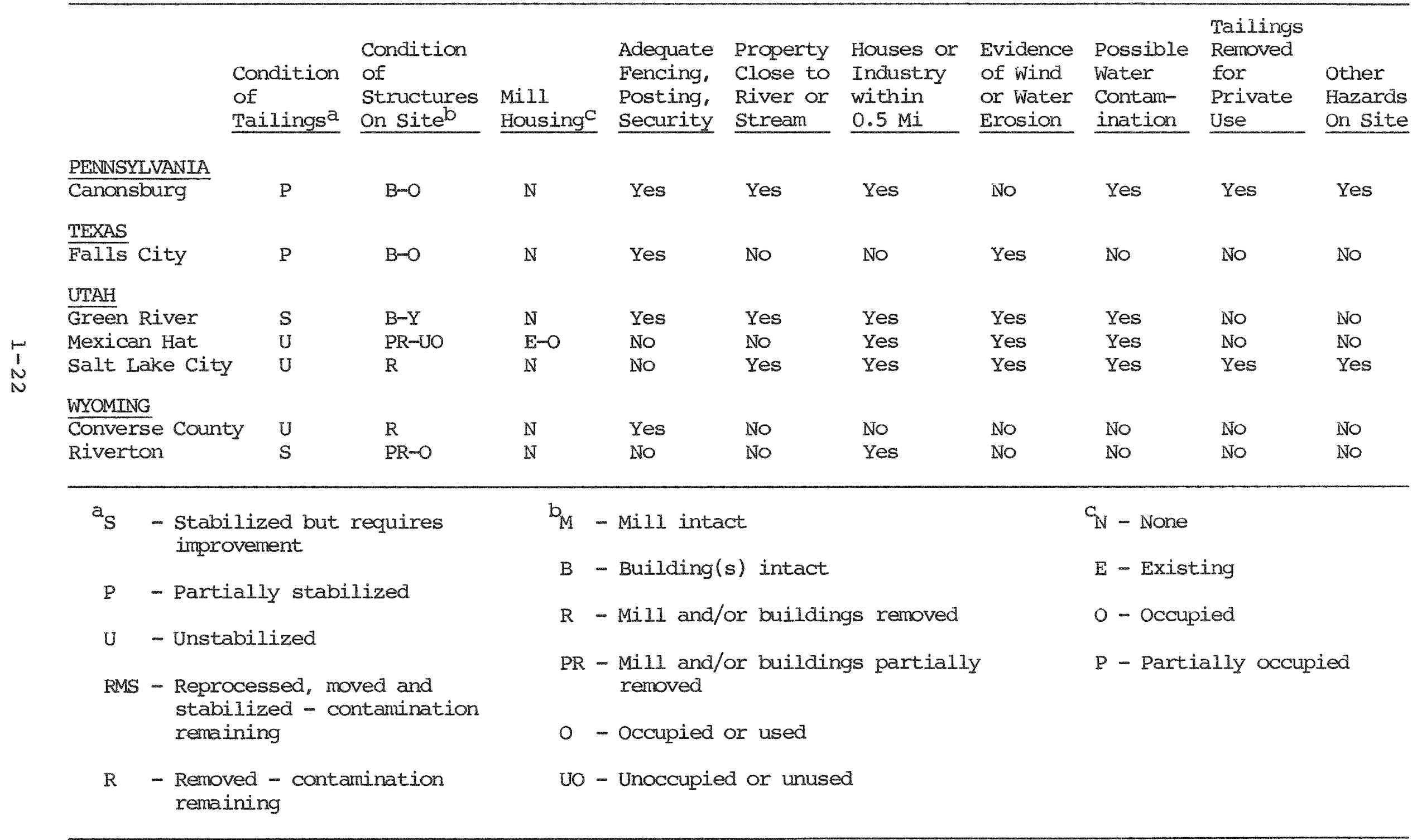


TABLE $\quad 1-2$

SUMMARY OF REMEDIAL ACTION OPTIONS AND EFEECTS

\begin{tabular}{|c|c|c|c|c|}
\hline $\begin{array}{l}\text { Option } \\
\text { Number } \\
\end{array}$ & $\begin{array}{l}\text { Site } \\
\text { Specific } \\
\text { Cost } \\
(\$ 000) \\
\end{array}$ & Description of Remedial Action & Benefits & $\begin{array}{l}\text { Adverse } \\
\text { Effects }\end{array}$ \\
\hline I & 10,200 & $\begin{array}{l}\text { The pile would be consolidated and stabilized } \\
\text { in place with } 3 \mathrm{~m} \text { of local earth cover, and } \\
\text { natural vegetation would be established or a } \\
\text { riprap cover provided. on-site contaminated } \\
\text { soil would be cleaned up, and the dike between } \\
\text { the pile and the river would be strengthened } \\
\text { with additional riprap. }\end{array}$ & $A-D, G$ & $X, Y, Z$ \\
\hline II & 23,000 & $\begin{array}{l}\text { The tailings, contaminated soil, and rubble } \\
\text { would be removed by truck to site } 14 \text {. } \\
\text { Whitewater Hill, located } 6.5 \mathrm{mi} \text { from the } \\
\text { tailings site. The tailings site and state } \\
\text { repository would be decontaminated as in } \\
\text { option I and released for unlimited use. }\end{array}$ & $A, B, D-G$ & $\mathrm{X}$ \\
\hline III & 28.600 & $\begin{array}{l}\text { Same as option II, except tailings removed } \\
\text { to site } 2 \text {. Grasso Mine Road, located } 10.5 \mathrm{mi} \\
\text { from the tailings site. }\end{array}$ & $A, B, D-G$ & $\mathrm{x}$ \\
\hline IV & 28,500 & $\begin{array}{l}\text { Same as option II, except tailings removed } \\
\text { to site } 7 \text {, Indian wash, located } 9.5 \mathrm{mi} \text { from } \\
\text { the tailings site. }\end{array}$ & $A, B, D-G$ & $x$ \\
\hline $\mathrm{V}$ & 25,700 & $\begin{array}{l}\text { Same as Option II, except tailings removed } \\
\text { to site } 19 \text {, East orchard Mesa, located } \\
11.5 \mathrm{mi} \text { from the tailings site. }\end{array}$ & $A, B, D-G$ & $\mathrm{X}$ \\
\hline
\end{tabular}




\begin{tabular}{|c|c|c|c|c|}
\hline $\begin{array}{l}\text { Option } \\
\text { Number }\end{array}$ & $\begin{array}{l}\text { Site } \\
\text { Specific } \\
\text { Cost } \\
(\$ 000) \\
\end{array}$ & Description of Remedial Action & Benefits & $\begin{array}{l}\text { Adverse } \\
\text { Effects }\end{array}$ \\
\hline VI & 27,000 & $\begin{array}{l}\text { Same as option II, except tailings removed } \\
\text { to site } 20 \text {, North Whitewater Creek, located } \\
11 \text { mi from the tailings site. }\end{array}$ & $A, B, D-G$ & $\mathrm{x}$ \\
\hline VII & 27.700 & $\begin{array}{l}\text { Same as option II, except tailings removed } \\
\text { to site } 21 \text {, East Coal Canyon, located } \\
11.1 \mathrm{mi} \text { from the tailings site. }\end{array}$ & $A, B, D-G$ & $\mathrm{X}$ \\
\hline VIIIA & 39,500 & $\begin{array}{l}\text { Same as option II, except tailings removed } \\
\text { to site } 22 \text {, unspecified site near DeBeque, } \\
\text { located } 35 \text { mi from the tailings site, by rail. }\end{array}$ & $A, B, D-G$ & $\mathrm{X}$ \\
\hline VIIIB & 41,900 & $\begin{array}{l}\text { Same as option II, except tailings removed } \\
\text { to site } 22 \text {, unspecified site near DeBeque, } \\
\text { located } 35 \mathrm{mi} \text { from the tailings site, by } \\
\text { truck. }\end{array}$ & $A, B, D-G$ & $\mathrm{X}$ \\
\hline
\end{tabular}

Notes

1. All options include on-site remedial action including tailings cleanup in an area generally north of the tailings.

2. For options II through VIII, costs include removal of 3 ft of contaminated earth below the tailings. 
TABLE $1-2$ (cont)

\section{Definition of Benefits}

A. On-site windblown tailings cleaned up

B. Wind and water erosion controlled

C. That portion of site not used for tailings available for other uses

D. Less likelihood of Colorado River flood washing away tailings

E. The source of gamma radiation and radon gas removed from site

F. Total tailings site available for unrestricted usage

G. Radon exhalation flux reduced to less than $2 \mathrm{pCi} / \mathrm{m}^{2}-\mathrm{s}$

Definition of Adverse Effects

$X$. Some security and maintenance required

$Y$. Tailings remain in the center of a rapidly growing area

z. Restricted use of tailings site 


\section{CHAPTER 1 REFERENCES}

1. "Summary Report, Phase I Study of Inactive Uranium Millsites and Tailings Piles"; AEC; Grand Junction, Colorado; Oct 1974 .

2. "Phase II - Title I Engineering Assessment of Inactive Uranium Mill Tailings, Grand Junction Site, Grand Junction, Colorado"; Ford, Bacon \& Davis Utah Inc.; Oct 1977.

3. F.F. Haywood, et al.: "Assessment of Radiological Impact of the Inactive Uranium Mill Tailings Pile at Grand Junction, Colorado": ORNL-5457; Apr 1980.

4. S.D. Shearer, Jr., and C.W. Sill; "Evaluation of Radon-222 Near Uranium Tailings Piles"; HEW; DER 69-1; Mar 1969.

5. D.L. Duncan, G.A. Boysen, L. Grossman, and G.A. Franz: "Outdoor Radon Study (1974-1975): An Evaluation of Ambient Radon-222 Concentration in Grand Junction, Colorado" ; Technical Note ORP/LV-77-1; EPA, Office of Radiation Programs; Las Vegas, Nevada; Apr 1977.

6. "Gamma Radiation Surveys at Inactive Mill Sites": Technical Note ORP/LV-75-5; U.S. Environmental Protection Agency; Las Vegas, Nevada; Aug 1975.

7. Federal Register, Part II; EPA Interim Primary Drinking Water Regulations; EPA; July 9, 1976.

8. H.W. Kraner, G.L. Schroeder, and R.D. Evans; "Measurements of the Effects of Atmospheric Variables on Radon-222 Flux and Soil-Gas Concentrations"; The Natural Radiation Environment; J.A.S. Adams and W.M. Lowder, eds; University of Chicago Press; 1964.

9. Argonne National Laboratory and Ford, Bacon \& Davis Utah, Inc.; "Characterization of Uranium Tailings Cover Materials for Radon Flux Reduction"; NUREG/CR-1081 (FBDU218-2): Mar 1980 .

10. "The Effects on Populations of Exposure to Low Levels of Ionizing Radiation: 1980"; Report of Advisory Committee on Biological Effects of Ionizing Radiation; NAS, National Research Council; 1980 .

11. B.L. Cohen; "The BEIR Report Relative Risk and Absolute Risk Models for Estimating Effects of Low Level Radiation"; Health Physics 37, 509; 1979.

12. Vital Statistics of the U.S.: Vol II; Mortality; National Center for Health Statistics; HEW; 1968. 


\section{CHAPTER 2}

SITE DESCRIPTION 
CHAPTER 2

SITE DESCRIPTION

The purpose of this chapter is to describe the physical characteristics of the Grand Junction site, its surroundings, and the characteristics of the tailings materials present on the site.

\subsection{LOCATION}

The Grand Junction millsite is located in Grand Junction, Mesa County, colorado. The site is bordered on the south by the colorado River and on the north by an industrial park, the Denver and Rio Grande Western Railroad, and the city metropolitan area. An aerial photograph of the site is included as Eigure 2-1.

The access to the mill buildings is at 12 th street and Winters Avenue, and the main entrance to the tailings pile is at the northwest corner of the pile on 9 th street and struthers Avenue. The site is in sections 23 and 24, Township 1 south, Range 1 West, Ute Principal Meridian, at 39 deg 03 min 17 sec north latitude and 108 deg 33 min west longitude.

\subsection{TOPOGRAPHY}

The city of Grand Junction and the millsite are located in Grand valley, a broad mountain valley on the western slope of the Rocky Mountains. The site is less than I mi upstream from the confluence of the colorado and Gunnison Rivers. The valley floor varies in elevation from 4,400 to 4,800 ft above sea level. The Book Cliffs are on the north and rise to elevations of $6.900 \mathrm{ft}$. Between the Book Cliffs and the Government Highline Canal, which generally parallels the Colorado River, there are washes, small hills, and valleys that are sparsely vegetated and unpopulated. To the south of Grand Valley are mountains that reach elevations of $8,000 \mathrm{ft}$, and the most predominant features are the sharply defined cliffs and valleys of the Colorado National Monument.

The existing site includes approximately 68 acres, of which the tailings occupy 61.13 acres. The base of the pile varies in height above the river from about 3 to $6 \mathrm{ft}$. The east side of the tailings surface is cone shaped with about a 30-ft rise from the edge of the pile to the top of the cone. The western side of the tailings surface is gently sloped. There are about 1,900,000 tons of tailings on the site.

The millsite and ore storage areas were in the northwest area of the site and occupied approximately 25 acres. Figure $2-2$ is a topographic map of the tailings area. 


\subsection{OWNERSHIP}

The climax Uranium Company, a division of American Metals climax, was the operational owner of this mill. The names have since been changed to AMAX Uranium Corporation, a division of AMAX, InC.

In mid-1976, the 61.13 acres on which the tailings are lorated was sold to the present owner, the sand Extraction Company of Moab, Utah, which is owned by $\mathbb{R}$. Shumay. nbout the same time, BESS Investments purchased the remaining 6.55 acres of the millsite including the remanning mill buildings. BESS is an acronym for Bonelia, Elliott, Sullivan, and sullivan. John Bonella and"R.G. Sullivan are the owners of Castings, lno." which was listed as the owner of the mill building property in the original report. The Grand Junction site was built on a beet sugar refinery site that consisted of approximately 200 acres.

of the original acreage, 40 acres comprising the raffinate pond area were deeded to the state of colorado by the AMAX subsiaxary, as a repository for tailings and contaminated earth gathered during the Grand Junction remedial action program. The state repository is east of the tailings. Eighty-five acres of land north of the tailings were sold to colorado West Improvement. Inc., an affiliate of the Grand Junction chamber of commerce, for an industrial park. Ten acres adjacent to the northeast corner of the state"s 40 acres were sold to L.D. Sievers.

The present ownership of the site is illustrated in Figure 2-3, which has been adapted from the site description and owership map prepared by FB\&DU for DoE and published in the Federal. Register. (1)

\subsection{HISTORY OF MILLING OPERATIONS AND PROCESSING (2)}

The Climax mill became operational in June 1951 with a production capability of 330 tons of ore per day; capacity was expanded to 500 tons/day in 1955. (3) The mill was shut down in March 1970, after processing a total of $2.2 \mathrm{mill}$ ion tons of uranium-vanadium ores. The tailings pile was partially stabilized in 1972 at a cost of about $\$ 125,000$.

Ores averaging $0.28 \% \quad \mathrm{U}_{3} \mathrm{O}_{8}$ and $1.41 \% \quad \mathrm{~V}_{2} \mathrm{O}_{5}$ were delivered to the Climax mill from all parts of the Uravan Mineral Belt of southwestern Colorado and eastern Utah, and from outlying axeas of southeastern Utah, western New Mexico, and northeastern Arizona. Roscoelite-type ores from the Rifle creek area in colorado also were processed. Most of the ore was trucked Erom these areas to the Grand Junction mill.

The AEC contracted with the climax Uranium company to purchase $\mathrm{U}_{3} \mathrm{O}_{8}$ in concentrate from July 1950 through December 
1900, during which time the AEC purchased 4,713 tons of ${ }_{3} \mathrm{O}_{8}$. After 1966, until the mill was shut down in 1970, uranzum oxide was sold in the comercial market. The vanadium oxide produced by the climax Uranium company was sold commercially. The process involved crushing and grinding the ore to a nomirad minus 28 mesh, then conditioning the ground ore with recirculated acid-bearing mill solutions, followed by neutralization with ammonia.(3) A sand/slime separation then was made. The sands constituted approximately $70 \%$ of the ore and contained approximately $30 \%$ of the values; these sands were acid-leached, washed, and discharged to tailings. The sines. which contained approximately $70 \%$ of the values, were dewatexed, dried, salt-roasted, water-leached for $\mathrm{V}_{2} \mathrm{O}_{5}$ recovery, dewatered, acid-ieached for $\mathrm{U}_{3} \mathrm{O}_{8}$ recovery, washed, and discharged to the tailings areas.

\subsection{PRESENT CONDITION OF THE SITE}

The tailings were stabilized in accordance with state of Colorado regulations in effect at the time. An estimated 174,000 tons of tailings were relocated in the old settling pond area immediately south of the remaining mill buildings in order to achieve a smoother pile surface. The tailings were covered with a minimum covering of 6 in. of material obtained from land immediately north of the tailings and millsite (land now owned by colorado West Improvement, Inc.). The stabilized pile then was seeded and a surface irrigation system was installed. The surface irrigation system was operated during the summer months for several years. The tailings are fenced and radiation warning signs are posted on the fence as required by the state of Colorado.

The site appears to be well stabilized against wind and water erosion, although rodents occasionally destroy the integrity of the stabilization. Human trespass has also degraded the cover surface. There are some inactive utility lines beneath the pile. There also is an 8-in. cast-iron water supply line, owned by the city of Grand Junction, which enters the tailings area at the northwest corner. A break in this line in 1973 resulted in water carrying tailings along the west edye of the pile and into the river. Since that time, a 1-in. bypass line has been installed to serve the remaining mill buildings. Access to an old 30-in. wood stave water supply line is located on the south side of the pile. This access is well fenced to prevent accidents around it.

The Grand Junction mill generated 2.2 miliion tons of tailings during its operation. However, an estimated 300,000 tons were removed and used for various purposes in the Grand Junction area prior to 1966.

The 40 acres now owned by the state of colorado contained three former effluent pond areas. Sediments from the north pond were recovered and sold as food stock for reprocessing. 
The south pond area, adjacent to the river, is the location now being used as a contaminated material repository area; this area has been diked to prevent erosion of the tailings by flooding of the river. The other pond area is not in use.

Debris from demolished mill buildings and the smokestack were placed in three tailings ponds located immediately south of the mill. The rubble was covered with $4 \mathrm{ft}$ of tailings. Of the original mill buildings, there remain only the east section of the large multistory main mill building, the east portion of the roaster building, and the laboratory and concentrate building. An estimated $7,000 \mathrm{yd}^{3}$ of brick and concrete from the mill buildings and foundations were placed as riprap along the river dike. Figure $2-4$ is a descriptive map of the tailings, mill building, and ore storage areas. Included in the figure are the locations of drill holes and test pits used for sampling and radiation measurements. To supplement the description of the site, a cross-section of the tailings pile is shown in Figure 2-5.

The off-site, construction-xelated remedial action program for structures in Grand Junction contaminated with uranium mill tailings is presently under way. An estimated 56,000 yd ${ }^{3}$ of tailings, contaminated soil, and concrete have been dumped on the state tailings repository site adjacent to the tailings pile on the east. The main mill building is being used as a welding shop and two people are employed there. The quonset hut structure to the east of the main mill building is used by a road service crew and two more people are employed there.

Residential construction has continued south of the Colorado River, and the industrial park has expanded north of the pile since the 1977 engineering assessment.

Battelle Pacific Northwest Laboratories has graded approximately 25 acres of the western portion of the site and is conducting tailings stabilization tests on site at the present time.

\subsection{TAILINGS AND SOIL CHARACTERISTICS}

The physical properties of the tailings indicate that they are finely ground and have some clay content. The types. volumes, and weights of materials presently on the site are summarized in Table 2-1. The average bulk density of the tailings is $90 \mathrm{lb} / \mathrm{ft}^{3}$. The bulk density and $\mathrm{pH}$ of soil samples from on-site test holes are given in Table 2-2. The pH of the soil is in the neutral range. Assays of composite uranium and vanadium tailings samples are shown in Table 5-1.

The tailings are a mixture of processed ore material and the chemicals used in the acid leach extraction process. These chemicals produced predominantly sulfate and chloride ion products. 
Approximately 10,000 tons of uranium-bearing material to be processed for uranium were removed from the mill and ore storage areas by $\mathrm{R}$. Shumway. (4) The processing was done in Moab, Utah, in Canyon City, Colorado, and at Ranchers reprocessing site in Naturita, Colorado. As much as $10 \mathrm{ft}$ of material were removed from a few localized areas.

Analyses of borings and samples indicate that the uranium tailings were not deposited uniformly in the ponds. This nonuniformity can be attributed to the refining process, the variety of ore sources, and the differential deposition and migration of sands and slimes from the discharge point.

The tailings rest on gravels and clays that range from 30 to $50 \mathrm{ft}$ in depth.

\subsection{GEOLOGY, HYDROLOGY, AND METEOROLOGY}

\section{7 .1 Geology}

The Grand Junction site is located on the modern flood plain of the colorado River. The Mancos Shale underlies the unconsolidated riverbed deposits and is exposed along the riverbank across from the tailings pile. The Mancos shale primarily consists of grey to dark-grey mudstones, but there are thin sandstone lenses and limestone concretions throughout the unit. only the lower 200 ft of the formation underlies the site as the upper section has been eroded to form the broad Grand Valley. These strata act as barriers to the downward and upward migration of ground waters.

The Dakota sandstone underlies the Mancos Shale, and the strata dip 5 to 10 deg toward the southwest. A simplified stratigraphic column of the rock formations is shown in Figure 2-6.

\section{7 .2 Surface Water Hydrology}

While no opportunity was provided for FB\&DU to conduct field evaluations of site hydrology, existing information was examined to characterize general hydrologic conditions in the vicinity of the site. The results of this survey are contained in this and Paragraph 2.7.3. Apparently no further hydrologic characterization of the Grand Junction tailings site is contemplated at this time.

The flowing surface waters near the site consist of the Colorado River on the south side of the pile and a drainage ditch along the eastern side. Standing water is present in excavations in the millsite area and in an unused water conduit beneath the tailings that runs diagonally from the river to the mill. A dry wash that occasionally carried irrigation flow along the western side of the pile is now partly filled with 
tailings from the pipe break mentioned earlier. These natural and man-made waterways are shown in Figure $2-7$.

The Colorado River and the Gunnison River, two major western rivers, merge approximately $0.75 \mathrm{mi}$ downstream from the tailings pile. At the tailings pile the colorado River is confined to a braided channel of which the most northern channel is less than 15 ft from the edge of the stabilized pile. The Colorado River has a long history of flooding at Grand Junction. peak runoff occurs from April through June as a result of snowmelt, occasionally augmented by rain. The peak flow of either an intermediate regional flood (100-yr flood) or a more severe standard project flood would result in flood waters overflowing the river banks upstream from the tailings and flowing along and across certain sections of the northern edge of the pile as well as along the riprap dike that protects most of the southern slope from erosion. (5) The northern edge of the tailings pile varies between 4,569 and 4,578 ft above sea level. The riverbed is at $4,555+3 \mathrm{ft}$, the intermediate regional flood level is at $4,571+\overline{3} \mathrm{ft}$, and the standard project flood level is at $4.572+3$ ft above sea level. Thus. during a major flood, the tailings pile would be an island surrounded by flood waters. There is no potential for flooding of the other ditches or surface water systems.

Contamination of the surface waters near the pile could result from physical transport of the tailings by overland runoff and by seepage from the pile. The degree of physical. transport of the tailings by overland flow has been reduced by contouring the pile, applying a 6-in. cover of soil, and seeding the surface. Nevertheless, should a cloudburst occur at the site, water runoff could erode some of the cover and tailings from areas where the vegetative stabilization is now weIl established. Chemical degradation of the surface waters due to seepage of precipitation through the pile is not likely owing to the pile's configuration and the limited rainfall and snow in the area: however, the sewerlines and waterlines could become channels for contamination. The fence along the western edge of the pile shows evidence of staining that may have resulted from leaching of tailings lying against the fence. There is evidence of leaching at certain areas on the pile. This leaching nay have taken place during operations or may have resulted from exposed tajlings or ore.

\subsubsection{Ground Water Hydrology}

The tailings lie directly on colorado River alluvial valley fill, which is underlain by a relatively thin (less than 200 ft) section of Mancos shale. The Mancos shale is relatively impermeable, is not a major aquifer, serves as a confining layer over the Dakota sandstone, and thus prevents downward migration of contaminants. Wells in the Grand Junction area, shown in Figure 2-8, tap ground water contained within the Entrada Sandstone, the wingate sandstone, the sandstone layers of the 
Morrison Formation, the sandstone layers of the Burro Canyon Formation, and the Dakota Sandstone. (6) These waters are under artesian pressure beneath the site, and the flow gradient of waters tends to be upward, thus preventing downward migration of contaminants.

The unconfined aquifers in the Grand Junction area consist of waters within the alluvial deposits of the Colorado River and its tributaries, within the terrace deposits, within weathered rock and soil, and in the Mancos shale. All of these sources yielded limited water supplies except for the alluvium within the flood plain of the colorado River and the Gunnison River. This water is too mineralized for domestic purposes.

At the site, the unconfined water within the alluvium fluctuates with seasonal Elows of the Colorado River and with the return of irrigation flows; thus water moves toward the river or locally parallels it except during peak flows. The water level may fluctuate several feet during the year, and there is evidence that the lowermost tailings are saturated by normal fluctuations of unconfined ground water. During an intermediate regional flood or a standard project flood, the unconfined water would rise as much as $10 \mathrm{ft}$ into the pile and saturate much of the tailings.

Contamination of unconfined ground water due to the fluctuation of water within the tailings has not been documented, but such a potential exists and can be avoided only by sealing the entire base and sides of the tailings at the subsurface interface with the highest water level. ongoing contamination due to seasonal fluctuations of the colorado River or irrigation flows would be local as the contaminants would be carried parallel into the river or directly into the river and eventualiy diluted. During active operation of the mill. there was deliberate percolation of water through the alluvial material in order to maintain a relatively constant level in tailings ponds. This source of contamination ceased with the closing of operations.

Recent $(7,8)$ and ongoing research by the Research Institute for Geochemical and Environmental Chemistry suggests that the presence of soluble sulfate salts in the tailings greatly inodifies the hydrologic environments of the pile. The principal investigator (7) states that "the general trend of material transfer within the piles is from the interior to the surface where salts with the contaminants precipitate." This phenomenon is believed to be active through cover material. Therefore, it could have a significant impact on disposal criteria.

\section{7 .4 Meteorology}

High-intensity rainfall such as thunderstorms can be expected an estimated 25 to 30 times in the Grand Junction area each summer.(9) These storms have not caused significant 
erosion in the past but could erode some of the steeper, less vegetated slopes. Average annual precipitation totals about 9 in. Large rainstorms usually occur from May through october. A rainfall of a 6-hr duration totaling 1 in. has a probability of occurring once in five seasons.

The weather data for Grand Junction have been gathered primarily at the airport north of town. The strongest winds are those associated with thunderstorms of prefrontal weather, and are generally from the south or southwest. A wind rose for the airport indicates a predominance of winds from the southeast quadrant. "Valley breeze" winds of this type will tend to flow up and down Grand Valley as depicted in Figure 2-9. A wind rose from the Grand Junction airport is given in Figure 2-10. 


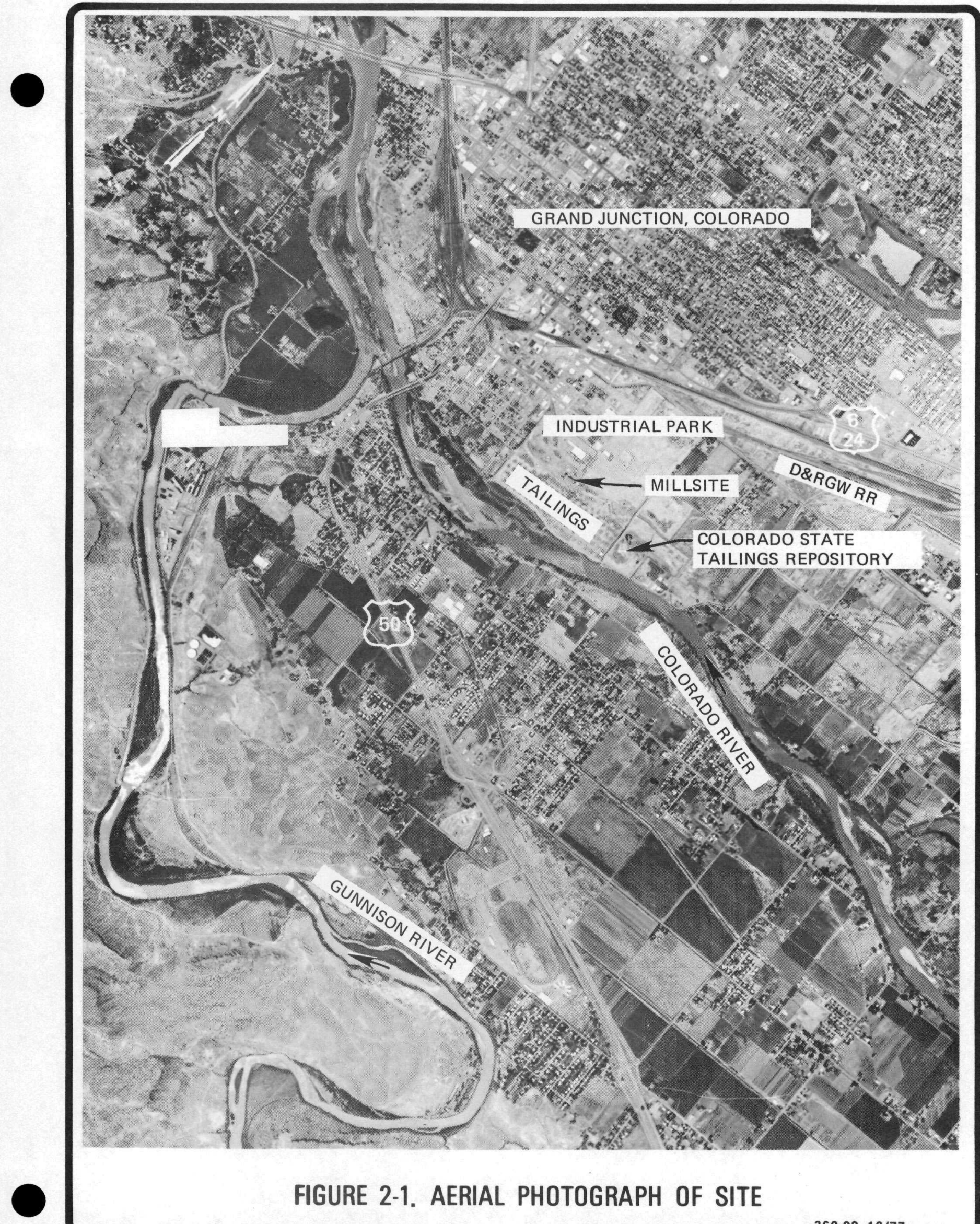

$\begin{array}{lll}360-09 & 10 / 77\end{array}$ 


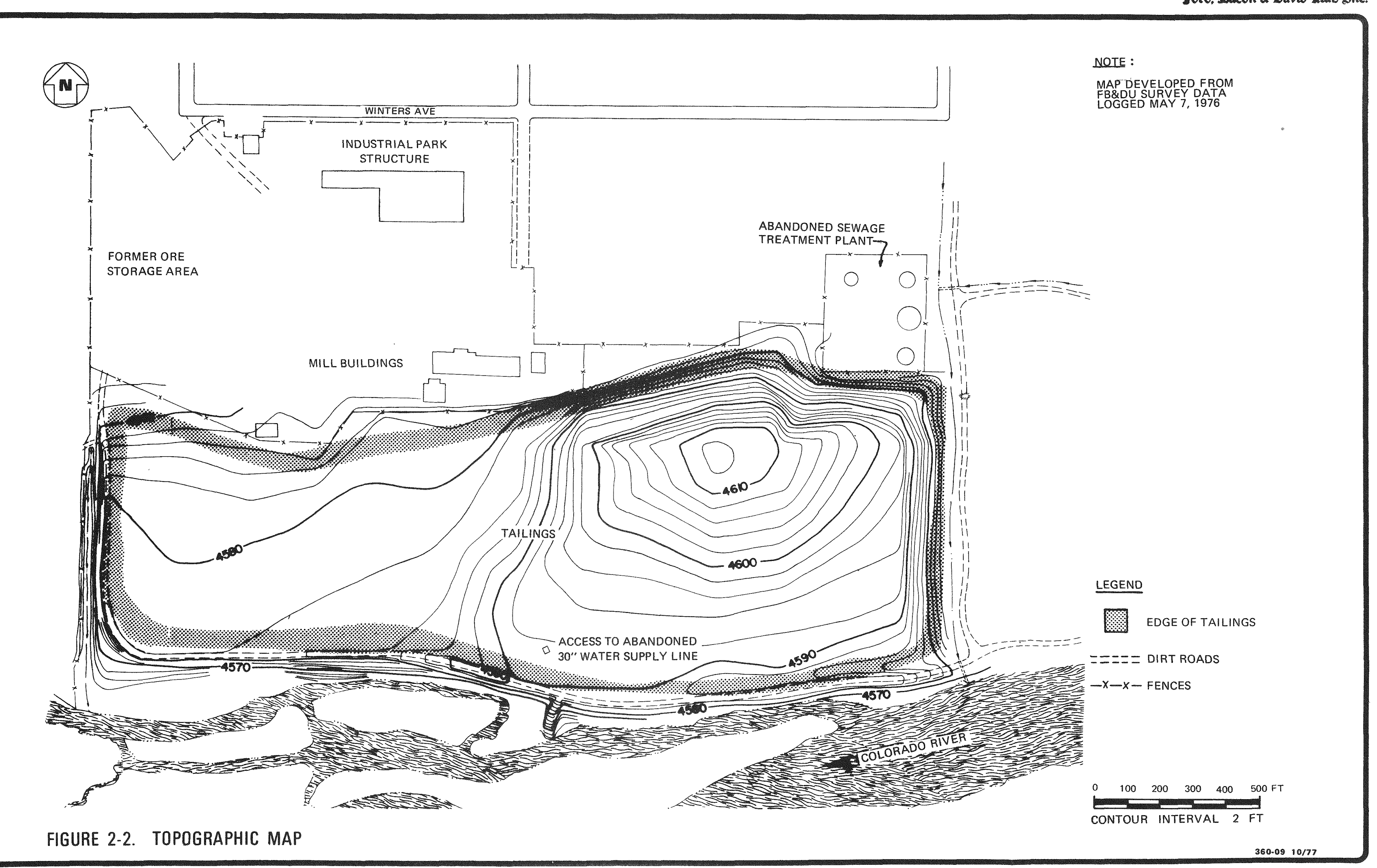




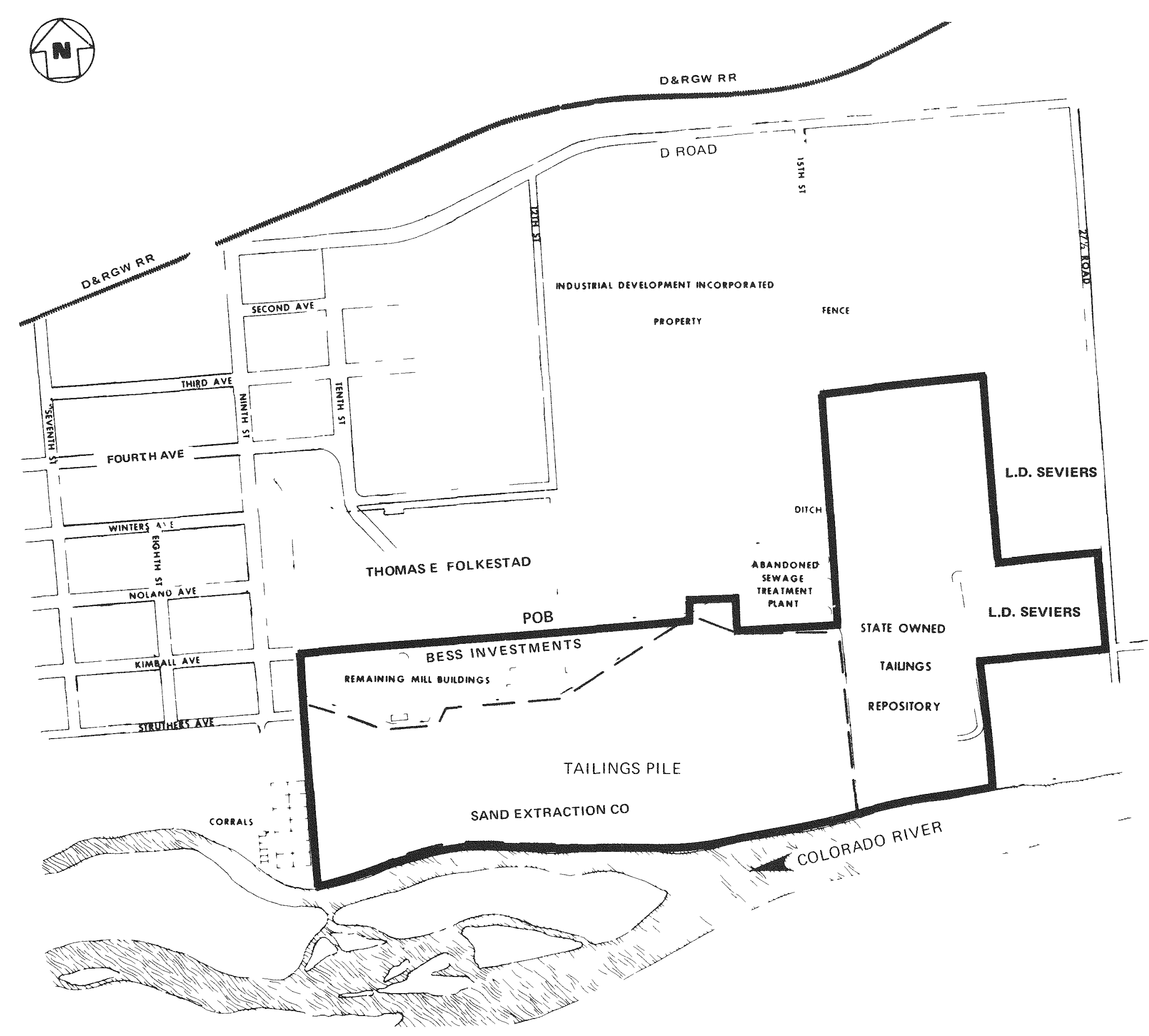

GRAND JUNCTION SITE

BEGINNING AT A POINT WHICH IS S 0016 $54^{\circ}$ "E, 1981.92 FROM A CITY MONUMENT MARK ING THE N E. CORNER OF SECTION 23, TIS, RIW, UTE MERIDIAN, CITY OF GRAND JUNC. TION, STATE OF COLORADO AND RUNNING THENCE N 89.56'27"E, 664.48 FT; THENCE
NORTH $67 \mathrm{FT}$, THENCE EAST 253 FT, THENCE SOUTH $144 \mathrm{FT}$, THENCE EAST $412 \mathrm{FT}$, THENCE NORTH ALONG THE EAST LINE OF 15 TTH STRE 144 T 1067 FT, THENCE EAST $770 \mathrm{FT}$ (MORE OR LESS) TO THE WEST LINE OF "PLEASANT VIEW SUBDIVISION", THENCE SOUTH ALONG SAID WEST LINE 830 FT. THENCE EAST ALONG THE SOUTH BOUNDARY OF SAID SUBDIVISION, 530 FT TO THE WEST RN LINE OF 27 1/2 ROAD, THENCE SOUTH ALONG SAID RMV LNE 480 FT WORE OR LESST. THENCE WEST 640 F, THENCE SOUTH 650 FT ALONG SAID NORTH BANK 3350 FT (MORE OR LESS) TO THE EXISTING CITY LMUTS LINE OF GRAND JUNCTION. THENCE N 0.03'30"E, ALONG SAID CITY LIMITS 1113.16 FT, THENCE S 89 $14^{\prime} 53^{\prime \prime} E, 1318.19$ FT TO THE POINT OF BEGINNING

CONTAINS 105 ACRES (MORE OR LESS)

NOTE: ADAPTED FROM REFERENCE 1 


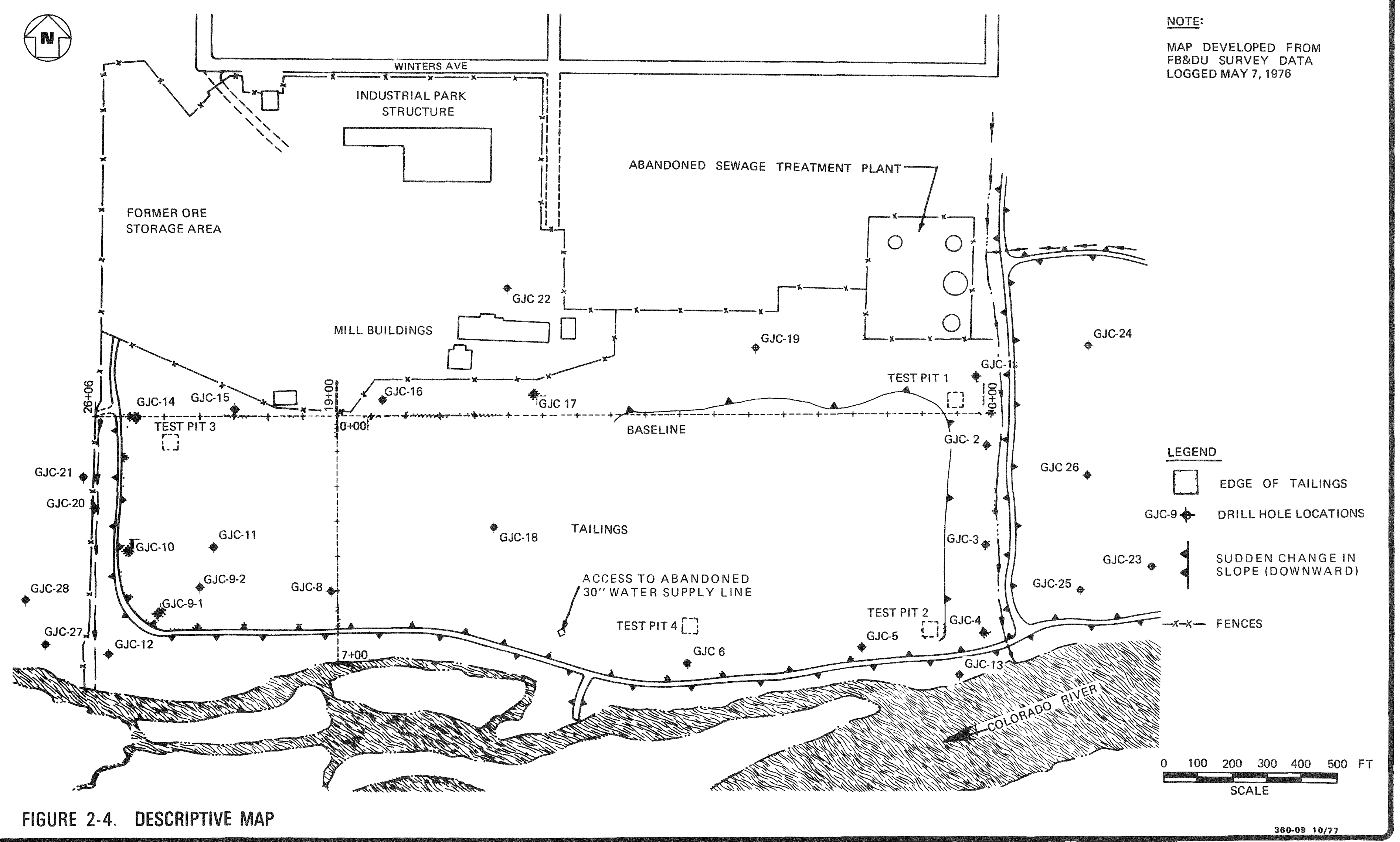


in

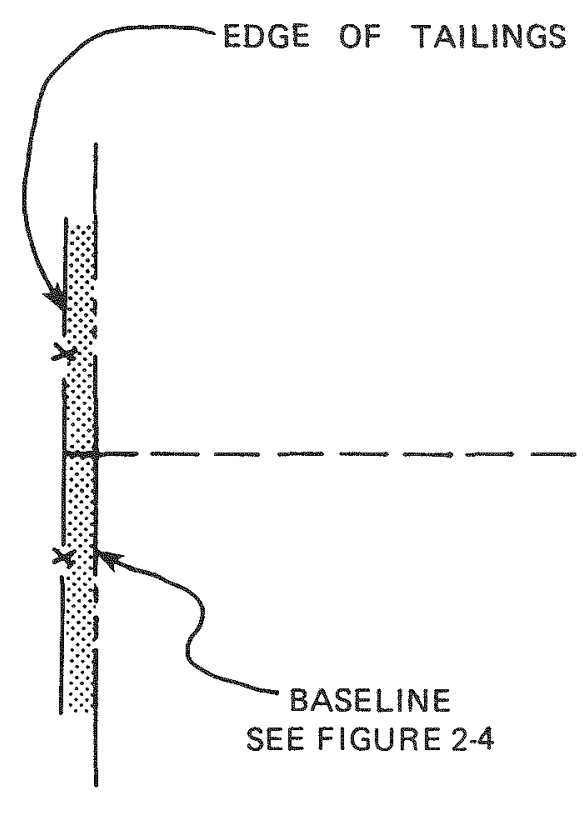

OP OF DIKE

EDGE OF TAILINGS

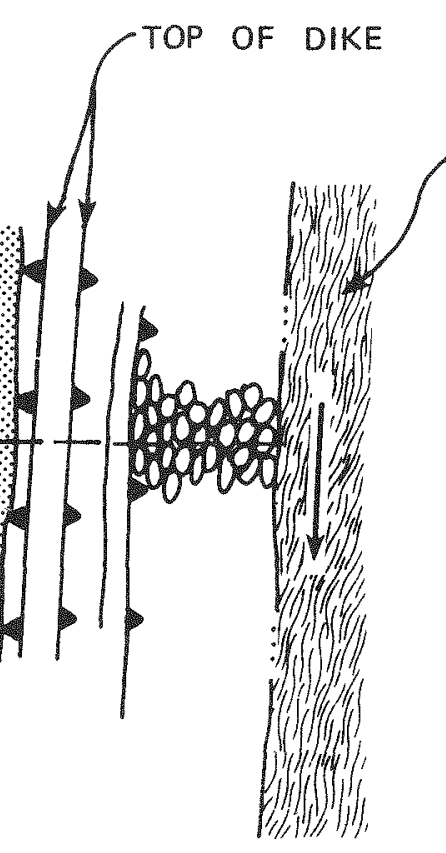

COLORADO RIVER

AT STATION $19+00$

PLAN

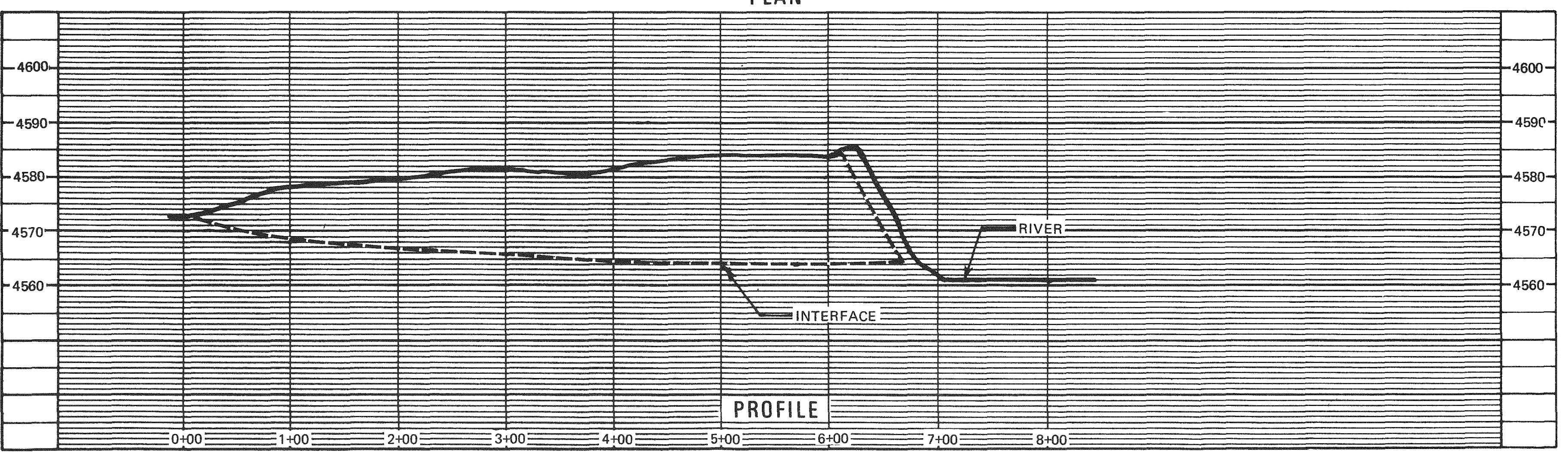

FIGURE 2-5. CROSS-SECTION AT STATION $19+00$ 
Jord, Sacon \& Dapls atab Jnc.

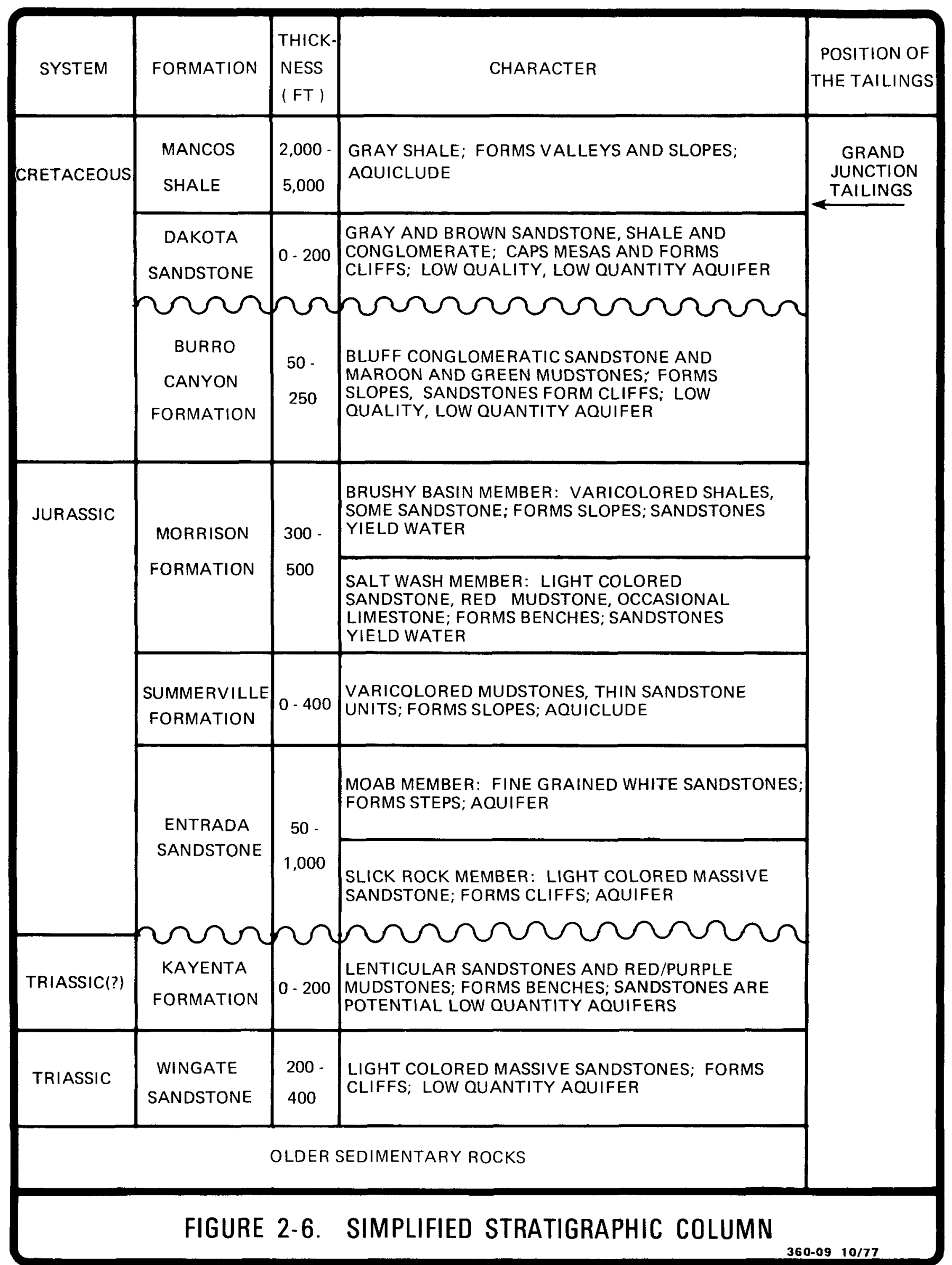




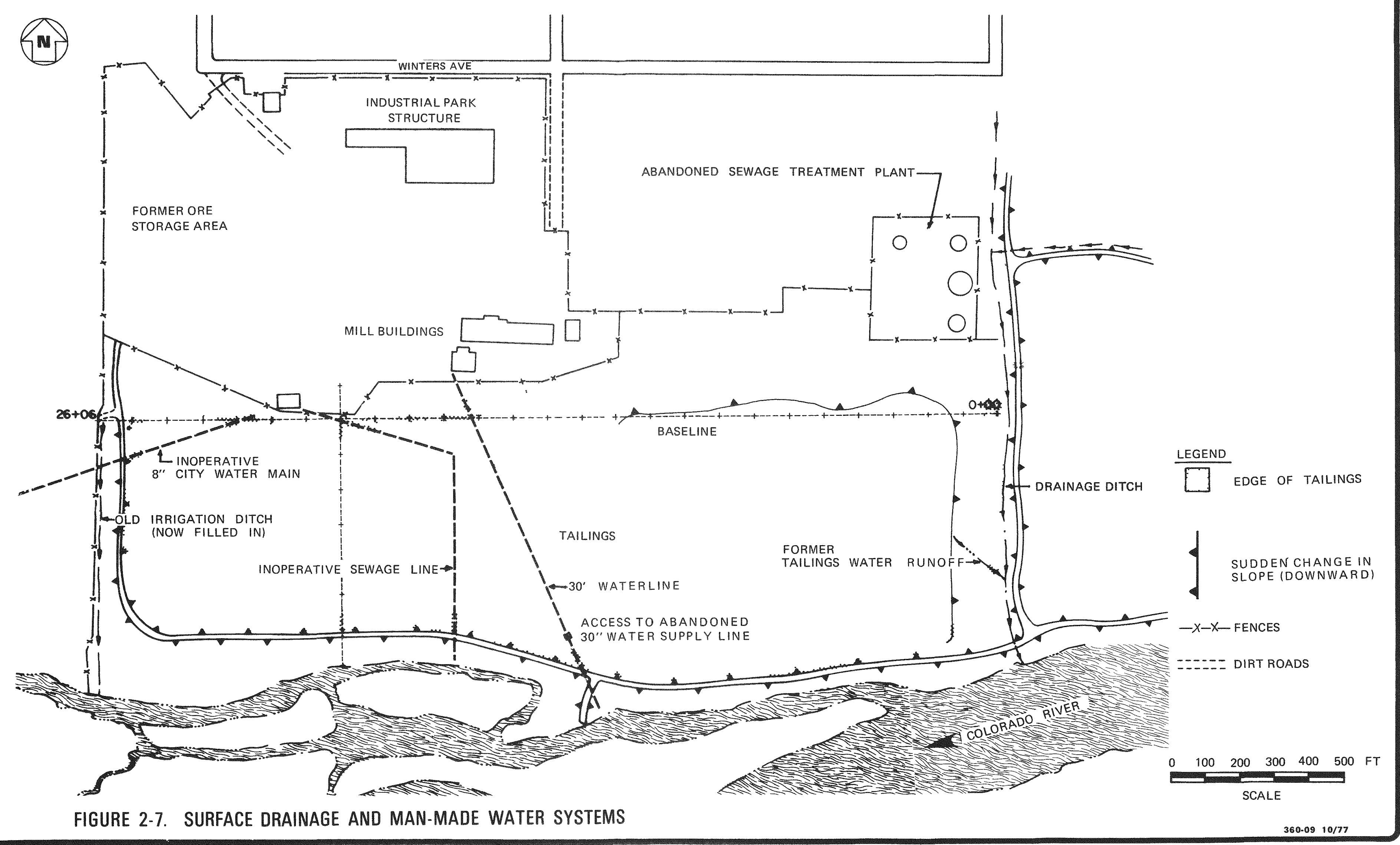




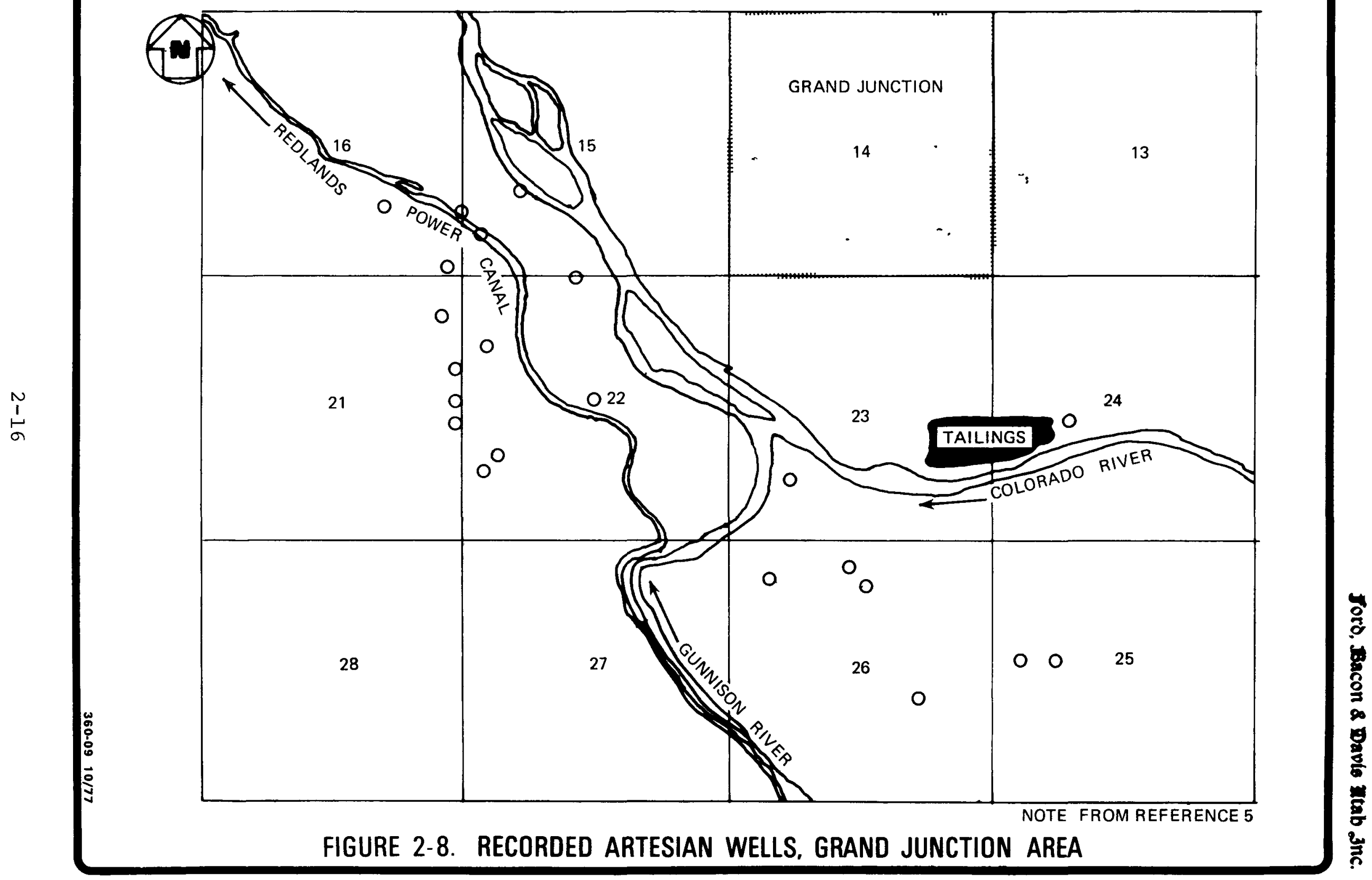




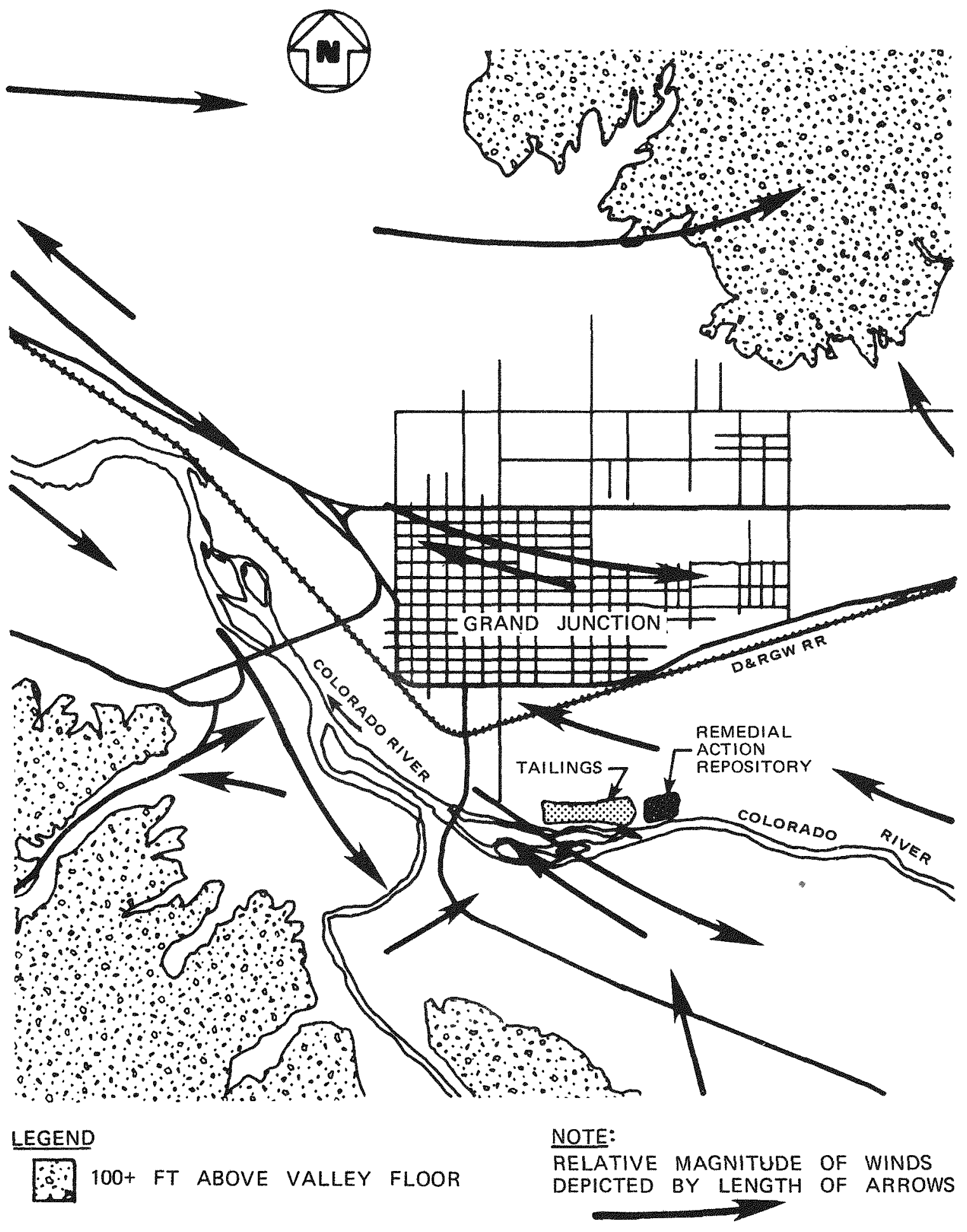

FIGURE 2-9. PREVAILING WIND DIRECTIONS 


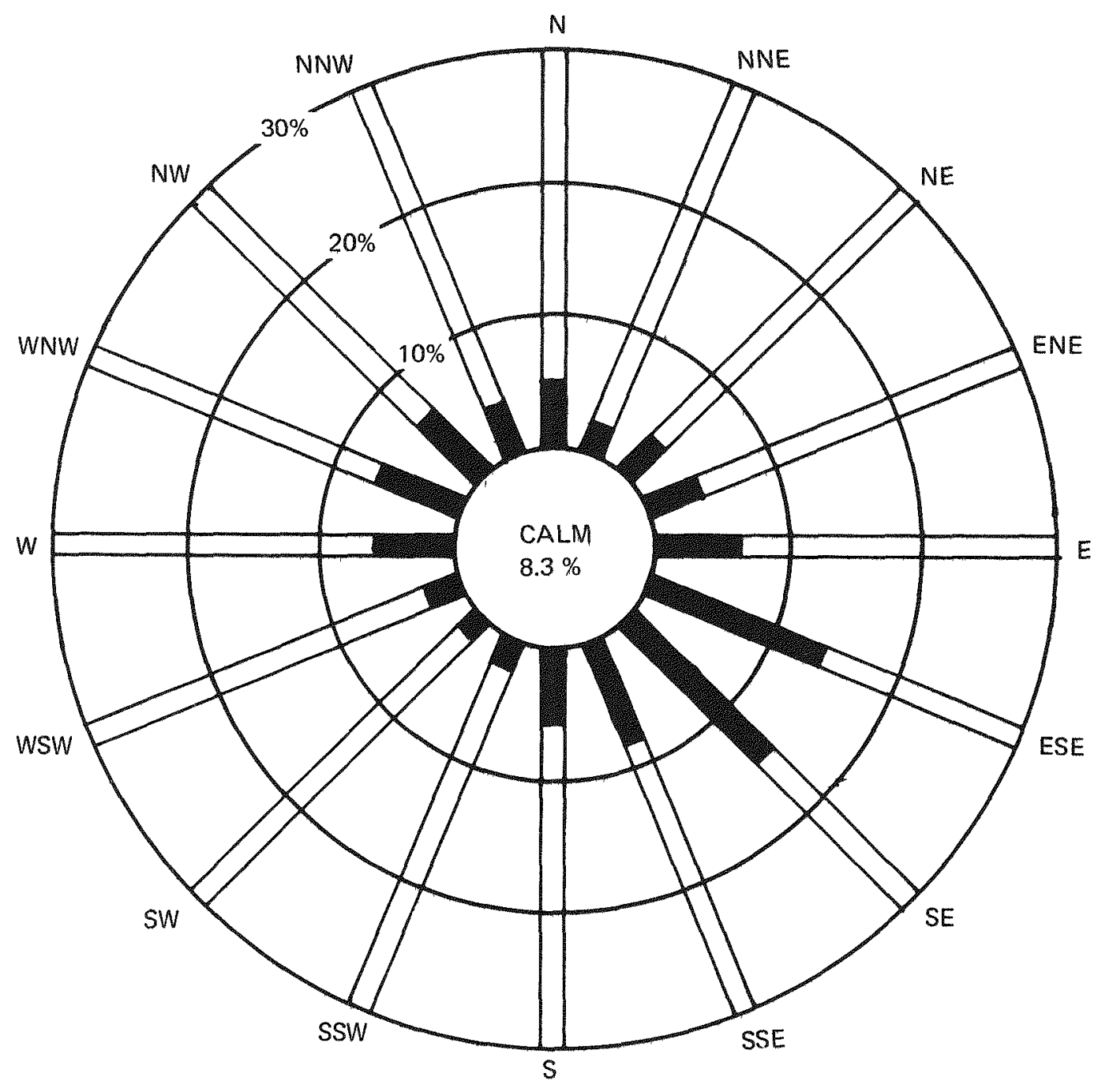

FIGURE 2-10. GRAND JUNCTION AIRPORT SURFACE WIND ROSE (CUMULATIVE DATA FROM 1948 THROUGH 1956) 


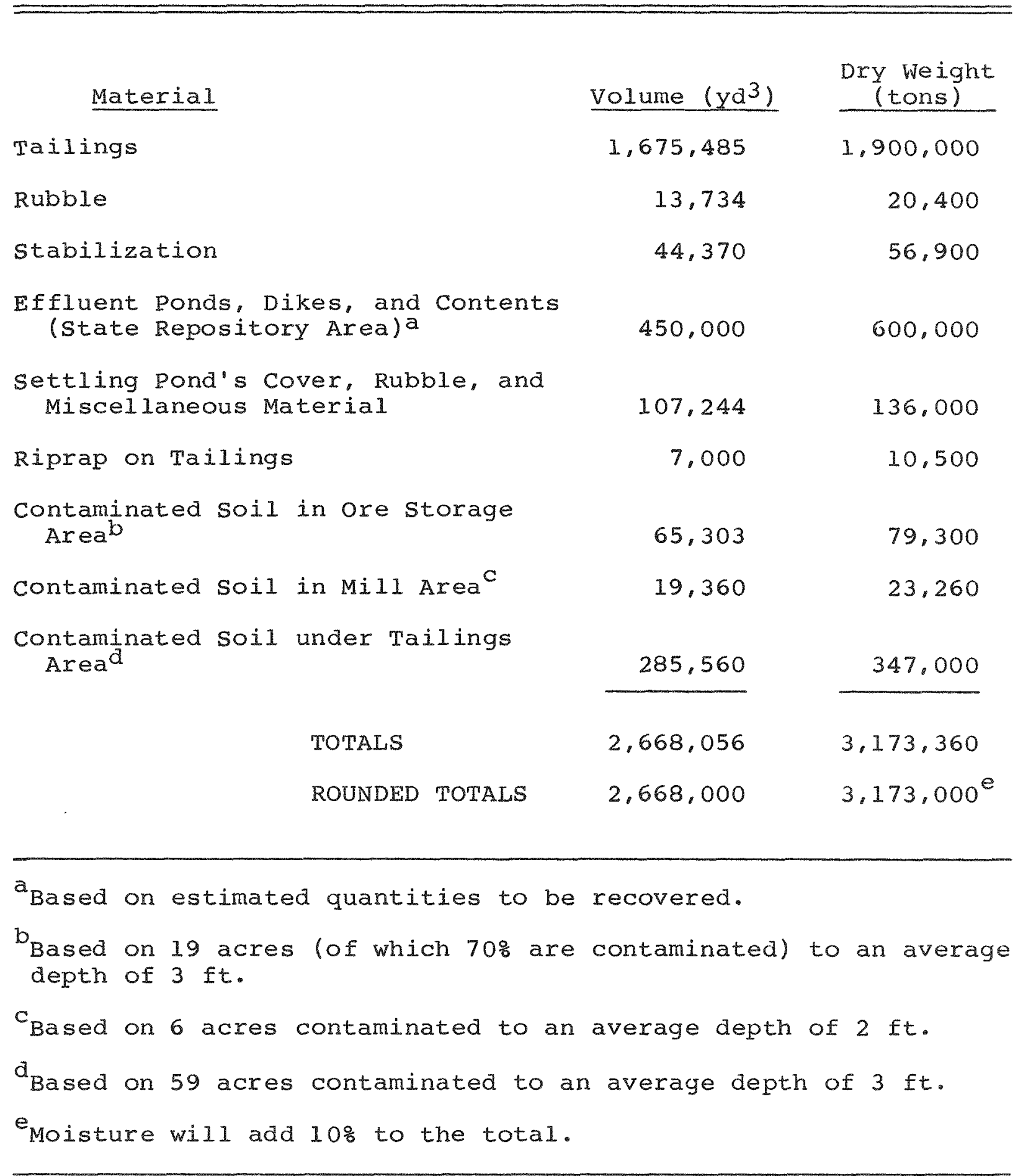


TABLE $\quad 2-2$

PHYSICAL PROPERTIES AND PH OF THE URANIUM TAILINGS

\begin{tabular}{|c|c|c|c|}
\hline $\begin{array}{l}\text { Sample* } \\
\text { Location }\end{array}$ & \& Water & $\begin{array}{c}\text { Bulk Density } \\
\left(1 \mathrm{~b} / \mathrm{ft}^{3}\right) \\
\end{array}$ & $\begin{array}{c}\mathrm{pH} \text { of soil } \\
\text { (5\% water by wt) }\end{array}$ \\
\hline $\mathrm{GJC}-2$ & 5.94 & 70.1 & 7.03 \\
\hline GJC -6 & -- & -- & 7.31 \\
\hline$G J C-10$ & -- & 68.7 & -- \\
\hline GJC -14 & $-\infty$ & $-\infty$ & 7.94 \\
\hline $\mathrm{GJC}-21$ & 29.16 & 109.9 & 7.52 \\
\hline $\begin{array}{ll}\text { Avg } & \text { GJC-2 } \\
\text { and } & G J C-21\end{array}$ & -- & 90.0 & -- \\
\hline
\end{tabular}

* See Figure 2-4. 
1. U.S. Department of Energy; "Proposed Designation of Processing Sites and Establishment of Priorities under the Uranium Mill Tailings Radiation Control Act of 1978 (Pub. I. 95-604)"; Federal Register, Vol 44, No. 173, $51894 ;$ Sep 5, 1979 .

2. "Phase I Reports on Conditions of Inactive Uranium Mi11sites, Grand Junction Report"; AEC; Grand Junction, Colorado; oct 1974 .

3. R.C. Merritt; The Extractive Metallurgy of Uranium; Colorado School of Mines Research Institute; Golden, Colorado; 1971 .

4. R. Shumway; personal conversation; oct 6,1980 .

5. "Flood plain Information for the colorado and Gunnison Rivers, Grand Junction, Colorado"; prepared for the Western Colorado Regional Planning Commission; U.S. Army Corps of Engineers; Grand Junction, Colorado; 1973.

6. S.W. Lowman; "Geology and Artesian Water Supply, Grand Junction Area, Colorado"; URS Company; Denver, Colorado; 1976 .

7. G. Markos; "Geochemical Mobility and Transfer of Contaminants in Uranium Mill Tailings": published in Uranium Mill Tailings Management - Proceedings of the second Symposium; Colorado state University; Fort collins, Colorado: Nov 19-20, 1979.

8. G. Markos and K.J. Bush; "Relationships of Geochemistry of Uranium Mill Tailings and Control Technology for Containment of Contaminants"; paper presented at the second U.S. Department of Energy Environmental Control Symposium; Mar 17-19, 1980 .

9. "Meteorology Affecting Uranium Tailings at Grand Junction, Colorado": URS Company, Denver, Colorado: 1976. 


\section{CHAPTER 3}

RADIOACTIVITY AND POLLUTANT IMPACT ON THE ENVIRONMENT 
CHAPTER 3

\section{RADIOACTIVITY AND POLLUTANT IMPACT ON THE ENVIRONMENT}

The principal objective of the assessment in this chapter is to determine the magnitude and characteristics of the radiation emitted from the Grand Junction uranium tailings pile and the resulting potential exposure to the population residing and working in the vicinity of Grand Junction, colorado. In addition, this chapter briefly describes the potential radioactive and chemical pollutants and their pathways in the environment. The notations and abbreviations used are given in Table $3-1$.

A radiological survey of the Grand Junction site was conducted by oak Ridge National Laboratory (ORNL) (I) concurrently with work performed by FB\&DU in 1976. The principal results of that work are contained in this engineering assessment.

\subsection{RADIOACTIVE MATERIAL CHARACTERISTICS}

Many elements spontaneously emit subatomic particles; therefore, these elements are radioactive. For example, when the most abundant uranium isotope, $238 \mathrm{U}$, undergoes radioactive decay, it emits a subatomic particle called an alpha particle. After undergoing decay the $238_{\mathrm{U}}$ becomes $234 \mathrm{Th}$, which is also radioactive: 234 Th subsequently emits a beta particle and becomes $234 \mathrm{pa}$. As shown in Figure 3-1, this process continues with either alpha or beta particles being emitted, and the affected nucleus thereby evolves from one element into another. It is noted in Figure 3-1 that $230 \mathrm{Th}$ decays to $226 \mathrm{Ra}$, which then decays to $222 \mathrm{Rn}$, an isotope of radon. Radon, a noble gas, does not react chemically. The final product in the chain is $206 \mathrm{pb}$, a stable isotope that gradually accumulates in ores containing uranium. Uranium ore contains $226_{\mathrm{Ra}}$ and the other daughter products of the uranium decay chain. one of the daughters of $226_{\mathrm{Ra}}$ is the isotope $214 \mathrm{Bi}$, which emits a significant amount of electromagnetic radiation known as gamma radiation. Gamma rays are very similar to $x$-rays, only more penetrating. The $214 \mathrm{Bi}$ is the principal contributor to the gamma radiation exposure in the uranium-radium decay chain.

Besides knowing the radioactive elements in the decay chain, it is also important to know the rate at which they decay. This decay rate, or activity, is expressed in curies (Ci) or picocuries (pCi), where 1 pci equals $10^{-12} \mathrm{Ci}$ or $3.7 \times 10^{-2}$ disintegrations per second. The picocurie often is used as a unit of measure of the quantity of a radioactive element present in soil, air, and water. 
Another important parameter used in characterizing radioactive decay is known as the "half $1 i f^{\prime} " T_{1} / 2$. This is the time that it takes for half of any initial quantity of the radioactive atoms to decay to a different isotope. For example, it takes $4.5 \times 10^{9}$ yr for half the $238 \mathrm{U}$ atoms to decay to $234 \mathrm{Th}$. Similarly, half of a given number of $222 \mathrm{Rn}$ atoms will decay in 3.8 days.

The activity and the total number of radioactive atoms of a particular type depend upon their creation rates as well as their half life for decay. If left undisturbed, the radioactive components of the decay chain shown in Figure 3-1 all reach the same level of activity, matching that of the longest-lived initiating isotope. This condition is known as secular equilibrium. When the uranium is removed in the milling process, $230_{\mathrm{Th}}$, which is not removed, becomes the controlling isotope. After processing the ore for uranium, the thorium, radium, and other nembers of the decay chain remain in the spent ore solids in the form of a waste slurry. The slurry is pumped to tailings ponds. The sands and slimes that remain constitute the tailings pile. Generally, as at Grand Junction, the slimes constitute only $20 \%$ of solid waste material, but they may contain $80 \%$ of the radioactive elements of major concern: radium and its daughters.

\subsection{RADIATION EFEECTS}

The radioactive exposure encountered with uranium mill tailings occurs from the absorption within the body of the emitted alpha and beta particles, and gamma radiation. The range of alpha particles is very short; they mainly affect an individual when the alpha emitter is taken internally. Beta particles have a much lighter mass and a longer range than alphas, but they still cause damage, mainly to the skin or to internal tissues when taken internally. Gamma rays, however, are more penetrating than $\mathrm{X}$-rays and can interact with all tissues of an individual near gamma-emitting material.

The biological effects of radiation are related to the energy of the radiation; therefore, exposure to radiation is measured in terms of the energy deposited per unit mass of a given material. In the case of radon and its daughter products, the principal effect is from alpha particles emitted after the radon and its daughter products are inhaled.

The basic units of measurement for the alpha particles from short-lived radon daughters are the working level (WL) and the working level month (WLM). The working level is defined as any combination of the short-lived radon daughters in a liter of air that will result in the ultimate emission of $1.3 \times 10^{5} \mathrm{MeV}$ of alpha energy. The working level is so defined because it is a single unit of measure, taking into account the relative concentrations of radon daughter products 
which vary according to factors such as ventilation. One wLM concentration (RDC) of 1 WL for a duration of $170 \mathrm{hr}$.

The basic units of measurement for gamma radiation exposure and absorption are the roentgen $(R)$ and the rad. One $R$ is equal to an energy deposition of $88 \mathrm{ergs} / \mathrm{g}$ of dry air, and 1 rad is the dose that corresponds to the absorption of 100 ergs/g of material. The numerical difference between the magnitude of the two units is often less than the uncertainty of the measurements, so that exposure of $1 \mathrm{R}$ is often assumed equivalent to an absorbed dose of 1 rad or a gamma dose of 1 rem.

\subsection{NATURAL BACKGROUND RADIATION}

There are several sources of radiation that occur naturally in the environment. Natural soils contain trace amounts of uranium, thorium, and radium that give rise to radon gas and to alpha, beta, and gamma radiation. The average background value in 12 off-site soil samples for each member of the uranium decay chain, assuming equilibrium, was $1.5 \mathrm{pCi} / \mathrm{g}$. (1) The sample locations within a 120-mi radius of Grand Junction and the corresponding $226_{\mathrm{Ra}}$ concentrations are shown in Figure $3-2$. previous measurements by the AEC in 1970 found $226_{\text {Ra concen- }}$ trations of 1.0 to $1.22 \mathrm{pCi} / \mathrm{g}$ in Mancos shale and 0.53 to $0.95 \mathrm{pCi} / \mathrm{g}$ in the Brushy Basin Formation. Colorado Department of Health measurements of radium concentration at 13 locations in Grand Junction ranged from 2 to $4 \mathrm{pCi} / \mathrm{g}$ with an average of $2.6 \mathrm{pCi} / \mathrm{g}$. Another natural source of radiation in the environment arises from the decay of $232 \mathrm{Th}$, the predominant thorium isotope. The half-life of $232 \mathrm{Th}$ is $1.4 \mathrm{x} 10^{10} \mathrm{yr}$. It is also the parent of a decay chain containing isotopes of radium and radon. The average background value in the same off-site samples for each member of the thorium decay chain, assuming equilibrium, is about $1.1 \mathrm{pCi} / \mathrm{g}$ of soil. Table $3-2$ Iists the major background radioactive sources. It is noted that background values of the radium and thorium chains vary with locations by factors of 7 and 4 , respectively.

The average radon concentration in Grand Junction was reported to be $0.83 \mathrm{pCi} / 1$ in $1969(2)$ and $0.74 \mathrm{pCi} / 1$ in 1974 and $1975(3)$ during year-long measurement programs. The average background values at various locations in Grand Junction given in those reports varied from 0.70 to $1.1 \mathrm{pCi} / 1$. Based on the previous measurements, a value of $0.8 \mathrm{pci} / 1$ was used as the average background value of radon concentration in this assessment.

Background gamma ray levels, as measured 3 ft above the ground, also were determined at several locations within $0.5 \mathrm{mi}$ of the site by using a calibrated and energy-compensated Geiger Mueller detector. A value of $11 \mu \mathrm{R} / \mathrm{hr}$ was established as the average background level, but the values ranged from 
8 to $12 \mu R / h r .(1)$ Cosmic rays are part of the measured background radiation levels. The contribution from cosmic rays is generally dependent upon the altitude and is approximately $6 \mu R / h r$ in the Grand Junction area, (4) or approximately $55 \%$ of the measured average background value.

\subsection{RADIATION EXPOSURE PATHWAYS AND CONTAMINATION MECHANISMS}

As noted previously, the principal environmental radiological implications and associated health effects of uranium mill tailings are related to radionuclides of the $238 \mathrm{u}$ decay chain: primarily $230_{\mathrm{Th}},{ }^{226} \mathrm{Ra}$, and $222_{\mathrm{Rn}}$ daughters. Although these radionuclides occur in nature, their concentrations in tailings material are several orders of magnitude greater than in average natural soils and rocks. The major potential routes of exposure to man are:

(a) Inhalation of the $222 \mathrm{Rn}$ daughters, from decay of $222 \mathrm{Rn}$ escaping from the pile; the principal exposure hazard is to lungs.

(b) External whole-body gamma exposure directly from the radionuclides in the tailings pile (primarily from $214 \mathrm{Bi}$ ) and in surface contamination from tailings spread in the general vicinity of the pile.

(c) Inhalation of windblown tailings; the primary hazard relates to the alpha emitters $230 \mathrm{Th}$ and $226_{\mathrm{Ra}}$, each of which causes exposure to the bones and the lungs.

(d) Ingestion by man of ground or surface water contaminated with radioactivity (primarily from $\left.226_{\mathrm{Ra}}\right)$ leached from the tailings pile or from solids physically transported into surface water.

(e) Erosion and removal of tailings material from the pile by flood waters or heavy rainfall; this can create additional contaminated locations with the same problems as the original tailings pile.

(f) Physical removal from the tailings pile also provides a mechanism for contamination of other locations.

(g) Contamination of food through uptake and concentration of radioactive elements by plants and animals is another pathway that can occur: however, this pathway was not considered in this assessment. 
The extent of radiation and pollution transport from the pile into the environment is aiscussed in the following paragraphs.

\subsubsection{Radon Gas Diffusion and Transport}

Locations and values of current field measurements of the radon exhalation flux from the tailings using the charcoal canister technique $(5)$ and canister locations are shown in Figure 3-3. The results of current measurements show the flux to range from 90 to $1,340 \mathrm{pCi} / \mathrm{m}^{2}-\mathrm{s}$ on the tailings pile, with a mean value on the pile of $550 \mathrm{pCi} / \mathrm{n}^{2}-\mathrm{s}$. At the time of the flux measurements the soil cover was dry and the weather was fair and warm. Radon flux from the state tailings repository immediately east of the tailings pile also was measured, where the mean value of $16 \mathrm{pCi} / \mathrm{m}^{2}-\mathrm{s}$ was determined. Radon flux depends principally on radium content of tailings; however, reported values of radon flux vary considerably between measurements taken at a single sample location at different times. These variations are due, in part, to differing moisture, soil, and climatological factors.

Radon gas concentrations above background, considered to be from the pile, have been detected at distances up to 1.5 mi from the site.(3) The locations and corresponding 24-hr average radon concentrations, including background, measured during this program with continuous radon monitors $(6)$ supplied by ERDA are shown in Figure $3-4$..

The radon measurements performed by FB\&DU were taken within $0.33 \mathrm{mi}$ from the pile with one exception. previous programs $(2,3)$ included extensive background measurements in Grand Junction and measurements at greater distances from the pile. An annual average radon concentration of $26 \mathrm{pCi} / 1$ with a range from 8 to $66 \mathrm{pCi} / 1$ was measured on the pile during the 1974 and 1975 program. (3) The Colorado Department of Health indicated an interest in radon concentrations near the pile in a westerly direction and, therefore, the locations in Figure 3-4 were chosen. The measured 24-hr average values of radon concentration varied from $6.7 \mathrm{pCi} / 1$ at $0.08 \mathrm{mi}$ to $2.6 \mathrm{pCi} / 1$ at $0.33 \mathrm{mi}$ from the pile toward the west. one on-pile measurement at the northwest corner averaged $59.4 \mathrm{pCi} / 1$ for a 24-hr period. Two other on-site measurements and one measurement in the industrial park immediately north of the site are given in Figure 3-4. A measurement $1.3 \mathrm{mi}$ northeast of the site yielded a $24-\mathrm{hr}$ average concentration of $1.5 \mathrm{pCi} / 1$; however, this was a tailings use location.

Variations of radon concentration at two locations during the 24-hr measurement period and the concomitant weather conditions at the airport are shown in Figures $3-5$ and 3-6. The sample location for Figure $3-5$ is the northwest corner of the tailings pile. Figure 3-6 illustrates the measurements $0.08 \mathrm{mi}$ west-northwest of the tailings. The measurements at 
the two locations were taken simultaneously. The diurnal variation is evident in both figures, with the off-pile increase lagging behind the on-site increase by about $1.5 \mathrm{hr}$.

Radon concentration measurements taken during this program genexally indicated increased concentrations during the night, reverting to background values during the day. The increase in concentration is probably the result of an inversion condition and reduced wind velocities. High winds tend to disperse the radon and generally do not result in significantly higher measurements of radon concentration downwind from the tailings pile.

The radon concentration measurements are plotted in Figure 3-7 as a function of distance from the edge of the tailings pile. Model calculations were performed with annual meteorology data to provide an additional estimate of the radon concentration in the vicinity of the pile. The FB\&DU model first determines radon flux and the total radon released from the pile with diffusion theory using radium soil concentrations and pile configurations deduced from the drilling and survey data. Then the radon transport off the pile is calculated by Gausian diffusion(7) plus wind drift conditions. The meteorology used in the calculations was based upon surface wind tabulations at the Grand Junction airport for the period 1959 through 1963. From the transport model the radon concentration was determined as a function of distance and direction from the tailings pile.

\subsubsection{Direct Gamma Radiation}

The external gross gamma radiation (EGR) levels measured on and in the vicinity of the tailings pile are shown in Figure 3-8. These measurements were taken with calibrated energy-compensated Geiger Mueller detectors.(1) The highest gross gamma radiation rate $(830 \mu \mathrm{R} / \mathrm{hr}$ ) was measured at the southeast corner of the tailings pile. Gamma measurements on the pile ranged between 60 and $350 \mu \mathrm{R} / \mathrm{hr}$. In the mill and ore storage areas, gamma radiation rates were measured from two times background to $300 \mu \mathrm{R} / \mathrm{hr}$ near the edge of the tailings pile. Measurements in the residential area to the west of the tailings were performed by the Colorado Department of Health and are included in Figure $3-8 .(8)$

Gross gamma rate measurements away from the tailings pile, taken at 100-yd intervals, reached background levels about $0.2 \mathrm{mi}$ to the east and west of the site. South of the site gamma radiation reached background levels across the river. North of the tailings, toward the center of the city of Grand Junction, gamma radiation reached background at about $0.35 \mathrm{mi}$ from the edge of the tailings pile. However, at distances over $0.2 \mathrm{mi}$ the gamma radiation was less than $5 \mu \mathrm{R} / \mathrm{hr}$ above background. These gamma radiation rate measurements 
are shown in Figure 3-9. The reduction of gamma radiation as a function of distance from the pile is shown in Figure 3-10.

In the northwest corner of the original millsite, on land now owned by Colorado west Improvement. Inc., the gamma radiation measurements ranged from background to 14 times background (150 $\mathrm{\mu R} / \mathrm{hr}$ ).

\subsubsection{Windblown Contaminants}

Another pathway is the result of windblown tailings. prevailing winds follow the river valley and, in the vicinity of the tailings pile, are from the northwest and southeast.

Figure 3-11 shows a background iso-exposure line due to the residual windblown tailings and designates the extent of windblown tailings as determined by the EPA. (9)

Measurements and data analyses were performed in 1980 to establish the boundary of that region around the site which exceeds $5 \mathrm{pCi} / \mathrm{g}$ of $226_{\mathrm{Ra}}$ concentration in the soil, believed to be due primarily to windblown contamination, and contamination in the former ore storage area. A leadshielded scintillometer, NaI (TI), was used. One end of the scintillometer was unshielded and directed toward the ground, where it was held about 1 in. above the soil surface. An unshielded reading was obtained. A 0.5-in.-thick lead shield was then placed between the detector and the soil surface and a second reading was taken. The difference between the unshielded and shielded readings, called the "delta", is an indication of the $226_{\mathrm{Ra}}$ concentration in the soil at that location. It has been experimentally determined that a delta of about 400 counts/min indicates a soil concentration of $226_{\mathrm{Ra}}$ of approximately $5 \mathrm{pCi} / \mathrm{g}$ above background with the meter used.

Twelve traverses with the scintillometer were conducted along lines away from the tailings pile, as shown in Figure 3-12. The 5-pCi/g contour around the site was estimated and is also indicated on the figure. One traverse passed through the former ore storage area west-northwest of the mill building area and contamination continued to be detected until the White Water Building Materials Company property was reached, 1,100 ft north of the tailings pile. Four of the traverses were taken along the south bank of the colorado River. No windblown contamination was detected along any of these traverses, although one unusually high reading was encountered. This was considered to be due to some local anomaly and not to windblown tailings.

Surface soil samples were taken in the area surrounding the tailings.(1) The sample locations and $226 \mathrm{Ra}$ concentrations are shown in Figure 3-13. The data show high levels of surface contamination in the vicinity of the site to the west, north, and east of the tailings pile. Soil samples taken about 
650 to 700 yd to the north, west, and east of the site contain 4. 9, and 40 times the average ${ }^{22} 6_{\mathrm{Ra}}$ background concentration of $1.5 \mathrm{pCi} / \mathrm{g}$, respectively. These high levels of $226_{\mathrm{Ra}}$ were outside the range of windblown tailings as determined by the EPA $(9)$ for this study.

Airborne radioactive particulates measured at six stations in the vicinity of the Grand Junction site averaged from 0.001 to 0.04 of the MPC in air for $226 \mathrm{Ra}$. (10)

Ten surface and subsurface soil samples were taken from a small, shallow ravine that runs along the west edge of the tailings pile. Samples from this ravine contained 226 Ra concentrations 2 to 500 times background which resulted from the 1973 pipe break. Approximately 140 tons of tailings were carried down the ravine into the Colorado River.

\subsubsection{Ground and Surface Water Contamination}

Eleven of the surface water samples that were taken from the vicinity of the tailings pile were analyzed for ${ }^{226} \mathrm{Ra}$. The results are shown in Figure 3-13. (1) Two samples were taken from the colorado River, one downstream and one upstream from the tailings pile. The upstream sample contained $0.51 \mathrm{pCi} / 1$ compared with the downstream sample of $0.06 \mathrm{pCi} / 1$. The quality of the colorado River with respect to $226 \mathrm{Ra}$ was closely monitored from 1961 through 1972. Average 226 Ra levels during this period were $0.18 \mathrm{pCi} / 1$ at DeBeque, Colorado, upstream from Grand Junction, and $0.16 \mathrm{pCi} / 1$ at Fruita, Colorado, downstream from Grand Junction. These measurements indicate no general increase in the $226_{\mathrm{Ra}}$ level due to the Grand Junction tailings pile. However, measurements have shown localized contamination, particularly after a heavy rainstorm. $(10)$

T'wo samples were taken from a drainage ditch that flows along the eastern edge of the tailings pile. These samples contained 0.90 and $0.75 \mathrm{pCi} / 1$ of $226 \mathrm{Ra}$. Another sample was taken from a stagnant pond on the colorado state Tailings Repository site. This sample contained $18.7 \mathrm{pCi} / 1$. Three samples were taken from staynant water in excavations on the tailings pile and from the former millsite. The ${ }^{226} \mathrm{Ra}$ content of these samples ranged from 3.4 to $87.2 \mathrm{pCi} / 1$. Two water samples were obtained from drill holes just off the southeast and southwest corners of the tailings pile. These samples contained 70.2 and $45.3 \mathrm{pCi} / 1$, respectively. The final sample was taken from the access to the water conduit passing under the tailings pile. The $226 \mathrm{Ra}$ content of this sample was $17.1 \mathrm{pci} / 1$. The stagnant water found on and about the tailings pile contained from about 3.2 to $82 \mathrm{pCi} / 1$. On the other hand, all flowing water was well below the combined limit of $5 \mathrm{pCi} / \mathrm{l}$ for $226_{\mathrm{Ra}}$ and $228_{\mathrm{Ra}}$ in the EPA drinking water regulations. Table 3-3 lists the concentrations of $230 \mathrm{Th}$ and $210 \mathrm{pb}$ in the water samples in addition to the $226_{\mathrm{Ra}}$ content. (1) 


\section{4 .5 Soil Contamination}

The amount of $226_{\mathrm{Ra}}$ activity in the tailings and the extent of leaching of radium from the tailings into the soil were determined by drilling holes in and around the tailings pile and into the soil beneath it. Also, one hole was drilled in the mill area. The radioactivity profile was measured in these holes with a Geiger tube probe in a lead shield that collimates the radiation. Soil samples also were taken from selected holes for radiometric analyses. The locations of the holes are shown in Figure 2-4.

Typical $226 \mathrm{Ra}$ activity profiles in the Grand Junction tailings and subsoil are shown in Figures 3-14 and 3-15. Figure 3-14 illustrates the ${ }^{226} \mathrm{Ra}$ profile at hole GJC-14, located on the northwest corner of the tailings pile. The profile was determined with the gamma probe and by analyses of samples taken from a nearby pit (test pit 3) dug with a backhoe. Sample analyses of the subsoil indicate radioactive contamination decreased to two times the average background value at $3 \mathrm{ft}$ below the original surface.(1)

The radiometric profile for hole GJC-l and analyses of samples from test pit 1 , located on the northeast corner of the tailings pile, is shown in Figure 3-15. Contamination of about three times the background value exists down to 5 ft below the tailings-soil interface. Radium activity reached as high as $1,800 \mathrm{pCi} / \mathrm{g}$ in some of the holes drilled into the tailings pile. Soil contamination beneath the tailings ranged from 2 to 5 ft.

Figure 3-16 shows that in general the radium concentration is estimated to be about $5 \mathrm{pCi} / \mathrm{g}$ approximately $1.5 \mathrm{ft}$ below the tailings-soil interface.

\section{4 .6 Off-Site Tailings Use}

An estimated 300,000 tons of uranium tailings(11) have been moved from the site and used as fill material on various construction projects, including about 50,000 tons under and around structures in Grand Junction. These 6,000 locations have been identified by door-to-door gamma surveys of individual locations. Corrective action at the locations exceeding the Grand Junction criteria is being carried out under the Grand Junction remedial action program. The off-site property problem is briefly discussed in Chapter 7 .

\subsection{REMEDIAL ACTION CRITERIA}

The Grand Junction criteria for remedial action were adopted as a basis for the engineering assessments that preceded the enactment of PL 95-604, the Uranium Mill Tailings Radiation control Act of 1978. The criteria adopted applied to: (a) the 
cleanup of structures (12) where tailings are present, and (b) the cleanup of open land.

Prior to passage of PL 95-604, the criteria applied to structures were the guidelines established by the U.S. Surgeon General by letter of July 27, 1970, to the Director of the Colorado Department of Health for use in dwellings constructed with or on tailings. The guidelines were expressed in terms of external gamma radiation and radon daughter concentrations.

By letter of December 1974, the EPA provided radiological criteria for decontamination of inactive uranium millsites and associated contaminated land areas. These criteria were expressed in terms of the "as low as practicable" philosophy and required that after remedial action has been completed, the residual gamna radiation levels should not exceed $40 \mu \mathrm{R} / \mathrm{hr}$ above background in unusual circumstances and must be near background levels in most cases. Furthermore, these criteria required that cleanup of radium contamination should reduce the soil concentration of radium to less than twice background. The stabilized tailings area should be designated as a controlled area, restricted from human occupancy and fenced to limit access. However, open land areas where residual gamma levels were less than $10 \mu R / h r$ above background were allowed to be released for unrestricted use.

Title II, section 206 of PL 95-604 required the EPA to promulgate standards for the protection of the public and the environment from radiological and nonradiological hazards associated with residual radioactivity (as defined in the Act) at inactive uranium mill tailings and depository sites. The EPA subsequently published both interim standards (45 FR 27366) and proposed cleanup standards (46 FR 2556). Some changes may be made based on public comments; however, in the absence of substantial new information, changes in the standards sufficient to affect the cleanup actions required or the estimated costs are not expected.

\subsubsection{EPA Interim and Proposed Standards}

The interim standards and the proposed cleanup standards require that remedial actions be conducted to provide reasonable assurance that:

(a) For a period of at least 1,000 yr following disposal:

(1) Radon released from the disposal site to the atmosphere would not exceed $2 \mathrm{pCi} / \mathrm{m}^{2}-\mathrm{s}$;

(2) Substances released from the disposal site to underground sources of drinking water would not contaminate the water in excess of 
limits described in the tabulation below; and,

(3) Substances released from the disposal site to surface waters would not contribute to contamination otherwise existing in the water.

Substance $\quad \underline{\mathrm{mg} / 1}$

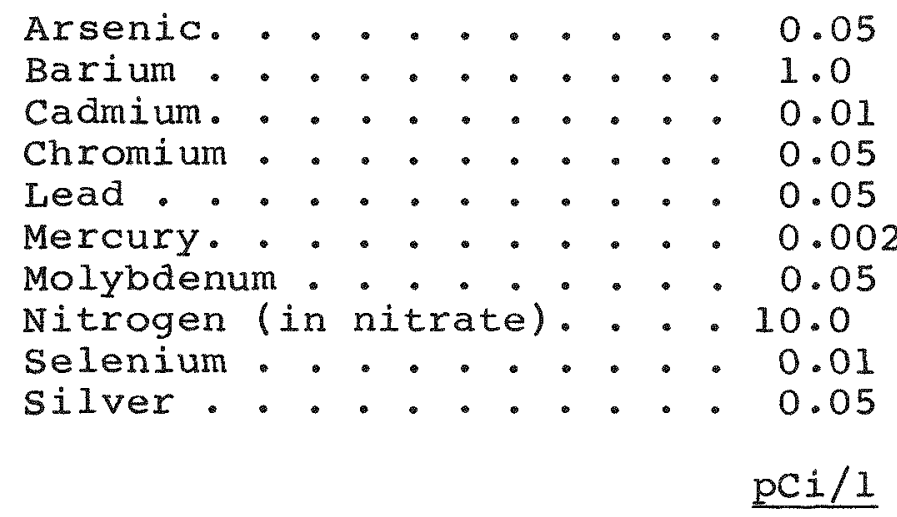

Combined $226_{\mathrm{Ra}}$ and $228_{\mathrm{Ra}}$. 5.0

Gross alpha particle

activity (including $226 \mathrm{Ra}$

but excluding radon and

uranium) . . . . . . 15.0

Uranium . . . . . . . 10.0

(b) The average concentration of $226 \mathrm{Ra}$ attributable to residual radioactive material from any designated processing site in any $5-\mathrm{cm}$ thickness of soils or other materials on open land within 1 ft of the surface, or in any $15-\mathrm{cm}$ thickness below I ft, shall not exceed $5 \mathrm{pci} / \mathrm{g}$.

(c) The levels of radioactivity in any occupied or occupiable building shall not exceed either of the values specified in the listing below. because of residual radioactive materials from any designated processing site.

Average annual indoor radon decay

product concentration--including

background (WL) . . . . . . . . . 0.015

Indoor gamma radiation--above

background $(\mathrm{mR} / \mathrm{hr})$.......... 0.02 


\title{
3.5.2 NRC Regulations on Uranium Mill Tailings
}

In the NRC's final regulations for uranium mill licensing requirements, amendments to 10 CFR Parts 40 and 150 incorporate licensing requirements for uranium and thorium mills including tailings and wastes into the Commission's regulations.

The amendments of part 40 , section $40.2 \mathrm{a}$, include the statement:

\begin{abstract}
Prior to the completion of the remedial action, the Commission will not require a license pursuant to this part for possession of byproduct material as defined in this part that is located at a site where milling operations are no longer active, if the site is designated a processing site covered by the remedial action program of Title I of the Uranium Mill Tailings Radiation Control Act of 1978. The Commission will exert its regulatory role in remedial actions, primarily through concurrence and consultation in the execution of the remedial action pursuant to Title I of the Uranium Mill Tailings Radiation Control Act of 1978.
\end{abstract}

In view of the foregoing and since under provisions of PL 95-604 a site on which tailings have been stabilized must be maintained under a license issued by the NRC, all uranium mill tailings disposal sites under PL 95-604 may eventually be subject to the criteria set out in Appendix A to Part 40. The criteria pertaining to tailings and waste disposal and stabilization that may apply in whole, or in part, to remedial action activities under PL 95-604 are summarized as follows:

Criterion 1 - The disposal site selection process should be an optimization to the maximum extent reasonably achievable for long-term isolation of the tailings from man, considering such factors as remoteness, hydrologic and other natural characteristics, and the potential for minimizing erosion.

Criterion 2 - To avoid proliferation of small waste disposal sites and thereby reduce perpetual surveillance obligations, with certain qualifications. byproduct material from in situ extraction operations and wastes from small remote above-ground extraction operations shall be disposed of at existing large mill tailings disposal sites. 
Criterion 3 - The prime option for disposal of tailings is placement below grade. Where this is not practicable, it must be demonstrated that an above-grade disposal program will provide reasonably equivalent isolation of tailings from natural erosional forces.

Criterion 4 - If tailings are located above ground, stringent siting and design criteria should be adhered to. Factors to be considered include the following:

(a) Minimization of upstream catchment area

(b) Topographic features for wind protection

(c) Relatively flat embankment slopes

(d) Self-sustaining vegetative or riprap cover

(e) Earthquake impact avoidance

(f) Promotion of soil deposition

Criterion 5 - Steps shall be taken to reduce seepage of toxic materials into ground water to the maximum extent reasonably achievable.

Criterion 6 - Sufficient earth cover, but not less than $3 \mathrm{~m}$, shall be placed over tailings or wastes at the end of milling operations to result in a calculated reduction in surface exhalation of radon from the tailings or wastes to less than $2 \mathrm{pCi} / \mathrm{m}^{2}-\mathrm{s}$ above natural background levels. Direct gamma exposure from the tailings or wastes should be reduced to background levels.

Criterion 11 - Provisions are set out for eventual transfer of ownership of the tailings to the state or to the United States.

Criterion 12 - The final disposition of tailings or wastes at milling sites should be such that ongoing active maintenance is not necessary to preserve isolation. Annual inspections should be conducted by owners.

EPA proposed and interim environmental standards for uranium mill tailings stabilization are generally consistent with NRC's proposed criteria as given above. However, they add the important further condition that the stabilization should be designed to provide reasonable assurance of remaining effective for at least $1,000 \mathrm{yr}$. 
An assessment has been made of the potential health impact of the tailings pile. The environmental pathways described in Paragraph 3.4 were evaluated. A summary of the evaluation of each pathway is presented below:

(a) Radon Diffusion - Inhalation of radon daughters From diffusing radon constitutes the most significant pathway and results in the largest estimated population dose. (1.13) Elevated concentrations were measured from 0.75 to $1.5 \mathrm{mi}$ from the tailings pile. $(2,3)$

(b) External Gamma Radiation - Gamma radiation above background is measurable to distances up to $0.25 \mathrm{mi}$ from the pile, an area with very few inhabitants. People on site will receive some gamma exposure unless the pile is covered with sufficient material to reduce the gamma radiation. Exposure to the local population within $0.2 \mathrm{mi}$ of the pile has been evaluated and found to have a negligible health impact compared with exposure from radon daughters.

(c) Airborne Activity - The limited, directional spread of significant quantities of windblown tailings toward inhabited areas indicates that direct inhalation or ingestion of tailings particles may be a minor component of the total population dose. This is a general result also reported at other uranium tailings piles. $(14,15)$ The present stabilization of the Grand Junction tailings against wind erosion has eliminated the gradual accumulation of tailings off the site and if this stabilization is maintained, windborne tailings from the pile will have a negligible impact on health effects.

(d) Water contamination - The low ${ }^{226} \mathrm{Ra}$ activity in the nearby colorado River indicates little, if any, contamination from the tailings pile, as confirmed by measurements since 1961. However, measurements do show localized water contamination, particularly after a heavy rain. $(10)$

(e) Subsoil contamination - Leaching of radioactive materials into the ground beneath the pile and at the millsite has been found at an average depth of about $3 \mathrm{ft}$; however, Colorado River water analyses do not indicate significant contamination from this pathway. 
(f) Physical Removal - Tailings have been used for construction-related applications. These tailings are sources of elevated gamma levels and radon daughter concentrations in and near structures. Radiation exposure to individuals living or working in these structures can be significant.

(g) Food-Chain Contamination - samples of drinking water, food, and milk taken during a study in 1965 indicated that the $226 \mathrm{Ra}$ intake by Grand Junction residents is similar to other parts of the U.S.(10) The Grand Junction study showed no unusually high level of $226_{\mathrm{Ra}}$ intake; therefore, the impact of the food chain was not considered further.

Only the potential health effects from the inhalation of radon daughters (pathway a) are estimated quantitatively in this assessment because this pathway produces the most significant exposure.(13-15) Furthermore, the uncertainty in the estimates of the potential health effects from this pathway far exceeds the magnitude of the health effects from the other pathways.

It is extremely difficult to predict with any assurance that a specific health effect will be observed within a given time after chronic exposure to low doses of toxic material. Therefore, the usual approach to evaluation of the health impact of low-level radiation exposures is to make projections from observed effects of high exposure on the basis that the effects are linear, using the conservative assumption of no threshold for the effects. The resulting risk estimators also have associated uncertainties due to biological variability among individuals and to unknown contributions from other biological insults which may be present simultaneously with the insult of interest. No synergistic effects are considered explicitly in this analysis. For the purpose of this engineering study, lung cancer is the potential health effect considered for RDC. The health effects were estimated using an absolute risk model.

\subsubsection{Assumptions and Uncertainties in Estimating Health} Effects

Since radiation exposure from $222 \mathrm{Rn}$ progeny is expressed in terms of working levels (WL) and working level months (WLM), total population exposures as well as health risk estimates are based upon these units, i.e., person-WLM. Exposures and resulting health effects are often expressed in terms of rems: however, estimates of the WLM-to-rem conversion factor for internal lung exposure to alpha particles from $222 \mathrm{Rn}$ progeny are observed to vary by over an order of magnitude.(16) presently, 
there are significant differences of opinion related to the choice of an appropriate conversion factor. Consequently, disagreements of calculated health effects from RDC occur when these effects are based on the rem.

The BEIR-III(17) risk estimator for lung cancer is based only on the absolute model since the relative risk model is not considered valid.(18)

The BEIR-III risk estimators for radon daughters are agedependent, with the age specified as the age at the diagnosis of cancer. The minimal latent period following exposure is also age-dependent. The following values can be determined:

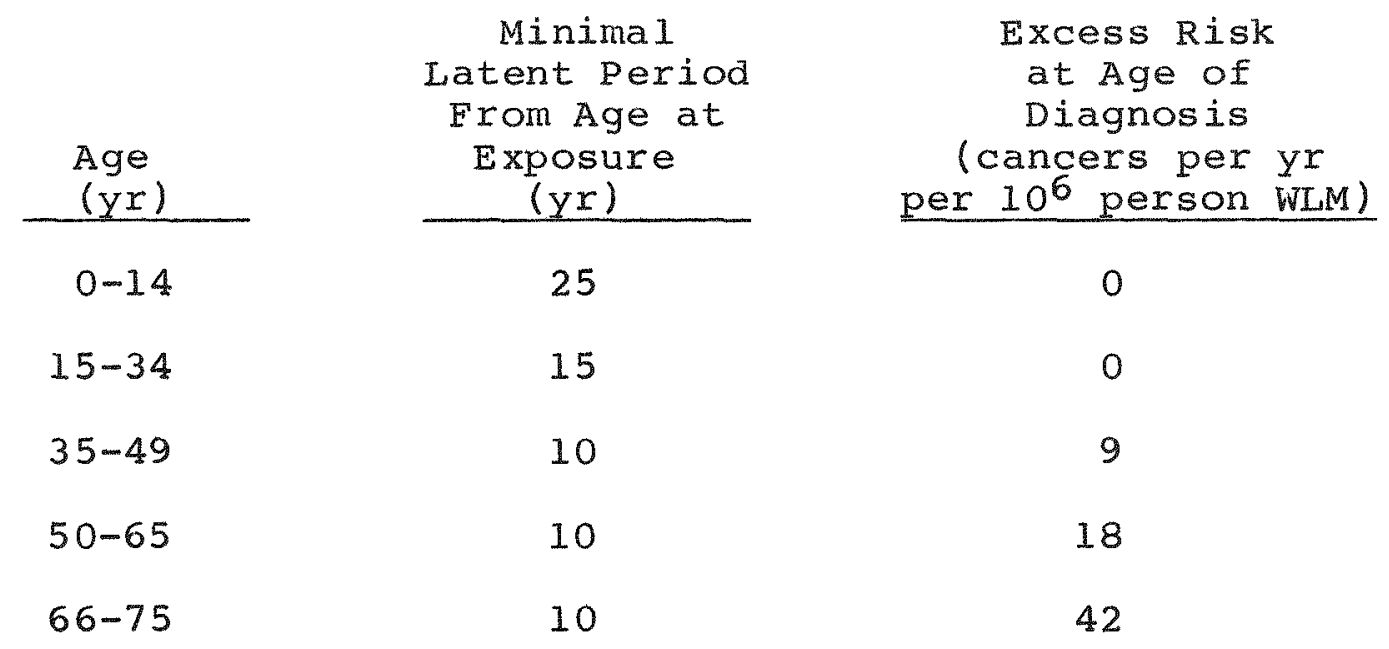

These risk values are expressed in terms of WLM using the BEIR-III recommended conversion factor of 6 rem per WLM. These risk estimators are based on combined estimates for uranium miners and fluorspar niners; no data exist that indicate whether these values may be used for groups irradiated in childhood. Nevertheless, in the treatment below they are conservatively assumed to apply to the population at large.

The BEIR-III report does not discuss plateau periods. However, some data presented in the report indicate cancers are still being detected as much as 50 yr after the period of exposure. Therefore, it is reasonable to assume that a lifetime plateau to age 75 may be applicable.

The age-dependent excess risks presented in the BEIR-III report must be adjusted, when applied to the population at large, to account for the fact that the breathing rate of miners on the job is about 1.9 times greater than that of the general population. (19) Since exposure is considered proportional to the breathing rate, the exposure (and hence the excess risk) of the general population would be smaller by this same factor. 
The cumulative risk estimator is obtained from the BEIR-III data adjusted for breathing rate by determining specific cancer risks for each year following an exposure. These risks are summed for the years between age at exposure and age 75 . The contribution to the cumulative risk estimator from each age group is weighted by the respective fractions of the U.S. population found in those age groups. (20) For the lifetime plateau to age 75, no cancers were assumed to occur in the years subsequent to age 75. The following cumulative risk estimator for the population at large is obtained using a lifetime plateau to age 75 and weighting by the age distribution of the U.S. population:

150 cancers per $y^{r} / 10^{6}$ person - WLM (continuous)

$(3-1)$

Because of the many factors that contribute to natural biological variability and of the many differences in exposures among miners and among the population at large, this risk estimator is considered to have an uncertainty factor of about 3 .

For the purpose of this assessment, equivalent working levels inside structures are determined from the radon concentration assuming a $50 \%$ equilibrium condition. This yields the following conversion factor:

$$
1 \mathrm{pCi} / 1 \text { of } 222_{\mathrm{Rn}}=0.005 \mathrm{WL}
$$

It is assumed that the component of indoor radon concentration due to radon originating from the pile is equal to the corresponding outdoor concentration component at that point. However, the total concentration of radon progeny is higher indoors owing to reduced ventilation, and to other sources such as building materials.

The exposure rate in terms of WLM/Yr can be obtained from a continuous $0.005-W L$ concentration as follows:

$$
(0.005 \mathrm{WL})\left(8766 \frac{\mathrm{hr}}{\mathrm{yr}}\right)\left[\frac{1 \mathrm{WLM}}{(1 \mathrm{WL})(170 \mathrm{hr})}\right]=0.25 \frac{\mathrm{WLM}}{\mathrm{yr}}
$$

The risk estimator used for continual exposure to gamma radiation is expressed as:(21) 
$72 * \dot{D}+0.8 * \dot{D}^{2}$ cancers per yr/106 person rems/yr-continuous

where $\dot{D}$ is the dose rate in rem/yr. In this assessment it is assumed that a gamma exposure of $1 \mathrm{R}$ in air is equivalent to a dose of 1 rem in tissue.

3.6.2 Health Effects

The health effects were calculated using a conservatively large flux of $1,000 \mathrm{pCi} / \mathrm{m}^{2}-\mathrm{s}$. This value was calculated using diffusion theory and the tailings physical properties. Even though the calculated value for radon flux appears much larger than the measured values, it is considered a more defensible estimate of the radon release rate since measurements of radon flux to date have been made only at a few points in time and give no suggestion of the magnitude of annual variations. In the absence of this information, the conservative estimate was chosen as the basis for health effect calculations.

The transport of radon from the tailings pile is modeled using a Gaussian plume model, meteorology characteristics of the Grand Junction area, site characteristics, and the population distribution surrounding the tailings pile as a function of radius and direction from the edge of the pile. Because of the nearness of residents to the tailings pile, the pile was modeled as a rectangular source to preserve geometric effects at points relatively near the source.

outdoor $222_{\mathrm{Rn}}$ concentration is shown as a function of distance from the edge of the pile in Figure 3-7. It is noted that the predicted $222_{\mathrm{Rn}}$ concentration at $0.2 \mathrm{mi}$ from the edge of the pile is less than two times background levels. Although the predicted radon concentrations appear to be much lower than the measured values in Figure 3-7, both measurements and predictions are still considered reasonable. Since data taken at sites 4 and 8 were also near smaller sources of radon (ore storage area and National Guard Armory, a tailings use location), their concentrations are expected to be unusually high. In other words, the radon concentrations at these two sites result from radon originating not only from the tailings pile, but also from the other sources nearby.

Data taken at sites 5, 6, and 7 consisted of one 24-hr measurement at each site and were taken during periods when the wind was predominantly from the direction of the tailings pile. By contrast, the model predictions are based on annual average meteorology. Thus, over a l-yr period, wind might come from the tailings pile to sites 5,6 , and 7 about $16 \%$ of the time. Therefore, it is not surprising that the predicted radon concentrations are lower than the measured concentrations. 
The population was distributed over an area within a 6-mi radius from the edge of the pile using 1980 census statistics from Grand Junction and vicinity, (22) as presented in Chapter 4. Three population projections to the year 2005 were used to provide a range of possibilities. The $0.8 \%$ constant growth rate and the $10 \%$ declining growth rate were derived from the earlier work by J.L. England.(23) The 6.38 declining growth rate was derived from the census records of the Grand Junction Census Division recorded for 1970 and 1980 and from Reference 23. The 6.3\% declining growth rate is considered to be the most likely in this report.

Tables 3-4 and 3-5 list the estimated health impacts from the tailings pile for 0 to $0.75 \mathrm{mi}$ and 0 to $6 \mathrm{mi}$ from the edge of the pile, respectively, based on the updated 1980 population figures. Also included are the 25-yr cumulative health effects for the $6.3 \%$ declining growth scenario. In Table 3-4, the health effects attributable to radon emanating from the pile are shown to be about $50 \%$ of those caused by background radon, for the vicinity within $0.75 \mathrm{mi}$ of the edge of the pile. However, for virtually the entire greater Grand Junction area (to $6 \mathrm{mi}$ from the edge of the pile), the health effects attributable to radon emanating from the pile are shown in Table 3-5 to be less than 8\% of those caused by background radon.

Health effects due to radon transport from the Grand Junction site in its present condition are estimated using indoor radon daughter concentrations deduced from predicted radon concentrations using expression (3-2) and then applying the risk estimator given in expression (3-1). Figure 3-17 shows the lung cancer risk per year from continuous exposure to radon as a function of distance from the edge of the tailings pile. The curve shown in the figure is the sum of the estimated annual radiation-induced risk from the Grand Junction tailings plus the area average lung cancer risk per year from all causes for residents of the state of colorado $\left(1.8 \times 10^{-4} / \mathrm{yr}\right) .(24)$ The curve shows that the risk for developing lung cancer from radon emanating from the whole site is less than twice the natural occurrence from all causes at a distance of $0.1 \mathrm{mi}$ from the edge of the pile.

Health effects from population EGR exposures due to the pile are less than $12 \%$ of the health effects from RDC exposures within $0.2 \mathrm{mi}$ of the edge of the pile, and drop to essentially zero at distances greater than $0.4 \mathrm{mi}$, where gamma levels are reduced to background.

The long-1ived precursors (230 Th and $226_{\mathrm{Ra}}$ ) will continue generating radon for many millennia. Consequently, the associated health effects of the pile will persist as long as it exists in its present condition and location. 


\subsection{NONRADIOACTIVE POLLUTANTS}

The tailings pile contains other potentially toxic materials. Chemical analyses of samples from auger holes in the Grand Junction tailings pile showed barium, chromium, and lead in concentrations between 25 and $130 \mathrm{ppm}$. The highest selenium concentration measured was $3 \mathrm{ppm}$; the arsenic was $14 \mathrm{ppm}$.

Fifteen water samples, obtained from the Grand Junction tailings pile and from the colorado River in the vicinity of the pile, were chemically analyzed. The locations of these samples are given in Figure 3-13 and Table 3-6.

All of these water samples, both upstream and downstream from the tailings pile, contained selenium above the EPA Interim Primary Drinking Water Regulations, as seen in Table 3-6. The selenium content in the Colorado River ranged from 4 to 8 times the EPA acceptable maximum of $0.01 \mathrm{mg} / 1$. Water samples also contained above acceptable or recommended levels of arsenic, cadmium, chromium, iron, and lead. The higher than acceptable levels of lead, arsenic, cadmium, and chromium were all found in stagnant water in excavations, drill holes, or the flume running under the tailings. All of the water samples also contained more iron than the USPHS recommended limit. A significant increase was observed in the selenium content of water flowing in the ditch east of the pile. All other elevated selenium and arsenic concentrations are associated with tailings materials at the sampling locations. 


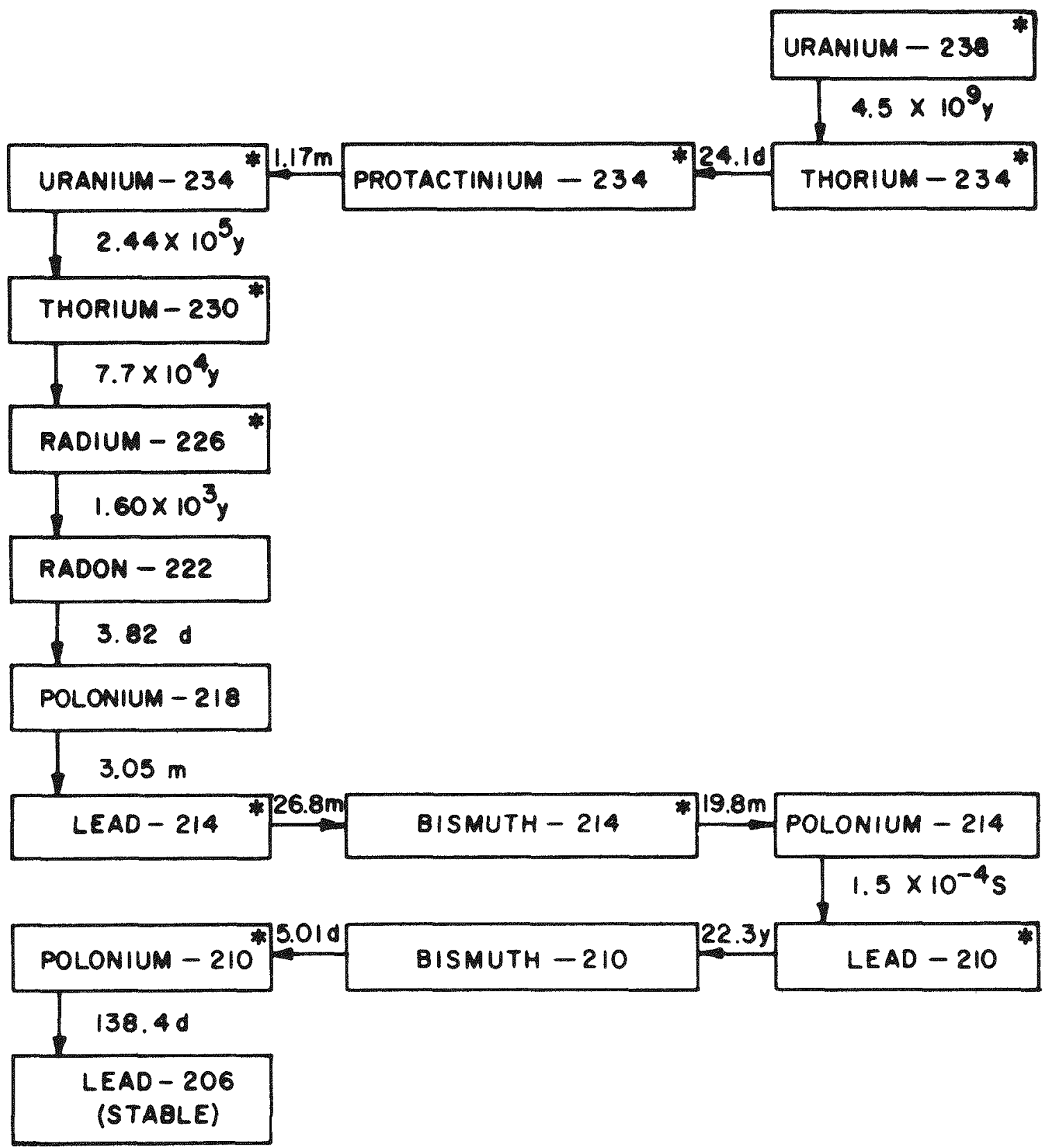

NOTE:

VERTICAL DIRECTION REPRESENTS ALPHA DECAY, HORIZONTAL DIRECTION INDICATES BETA DECAY. TIMES SHOWN ARE HALF LIVES. ONLY THE DOMINANT DECAY MODE IS SHOWN.

* also gamma emitTers

FIGURE 3-1. RADIOACTIVE DECAY CHAIN OF URANIUM 238 


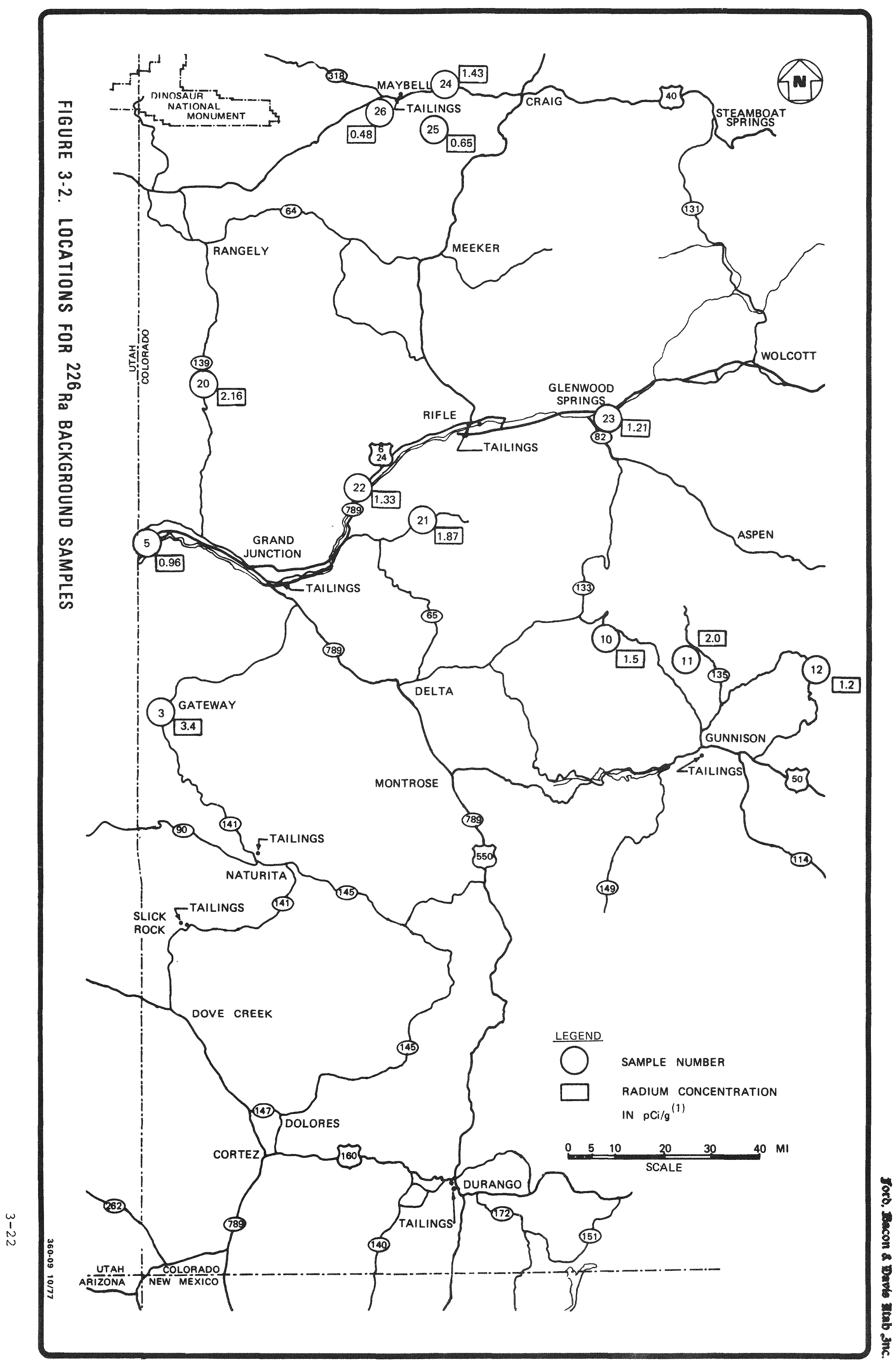




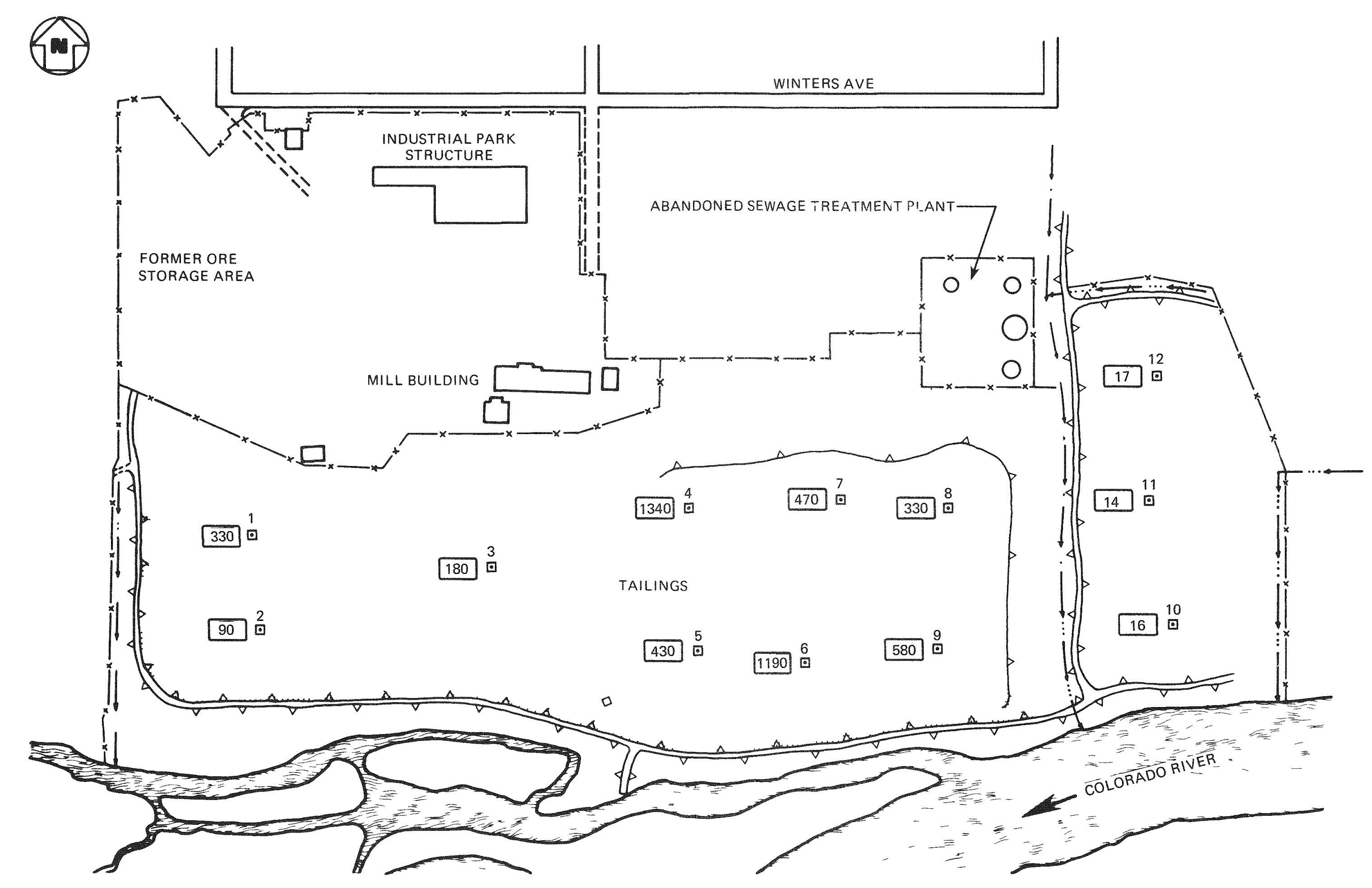

NOTE

MAP DEVELOPED FROM LOGGED MAY 7.1976

$\underline{\text { LEGEND }}$

470 RADON FLUX $\left(\mathrm{pCl}_{1} / \mathrm{m}^{2}-\mathrm{s}\right)$

$\square^{7}$ RADON FLUX SAMPLE LOCATION

- $-x-$ FENCES

3 EDGE OF TAILINGS

\& SUDDEN CHANGE IN SLOPE (DOWNWARD)

$0 \quad 100200300400500 \mathrm{FT}$

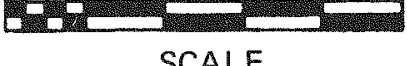




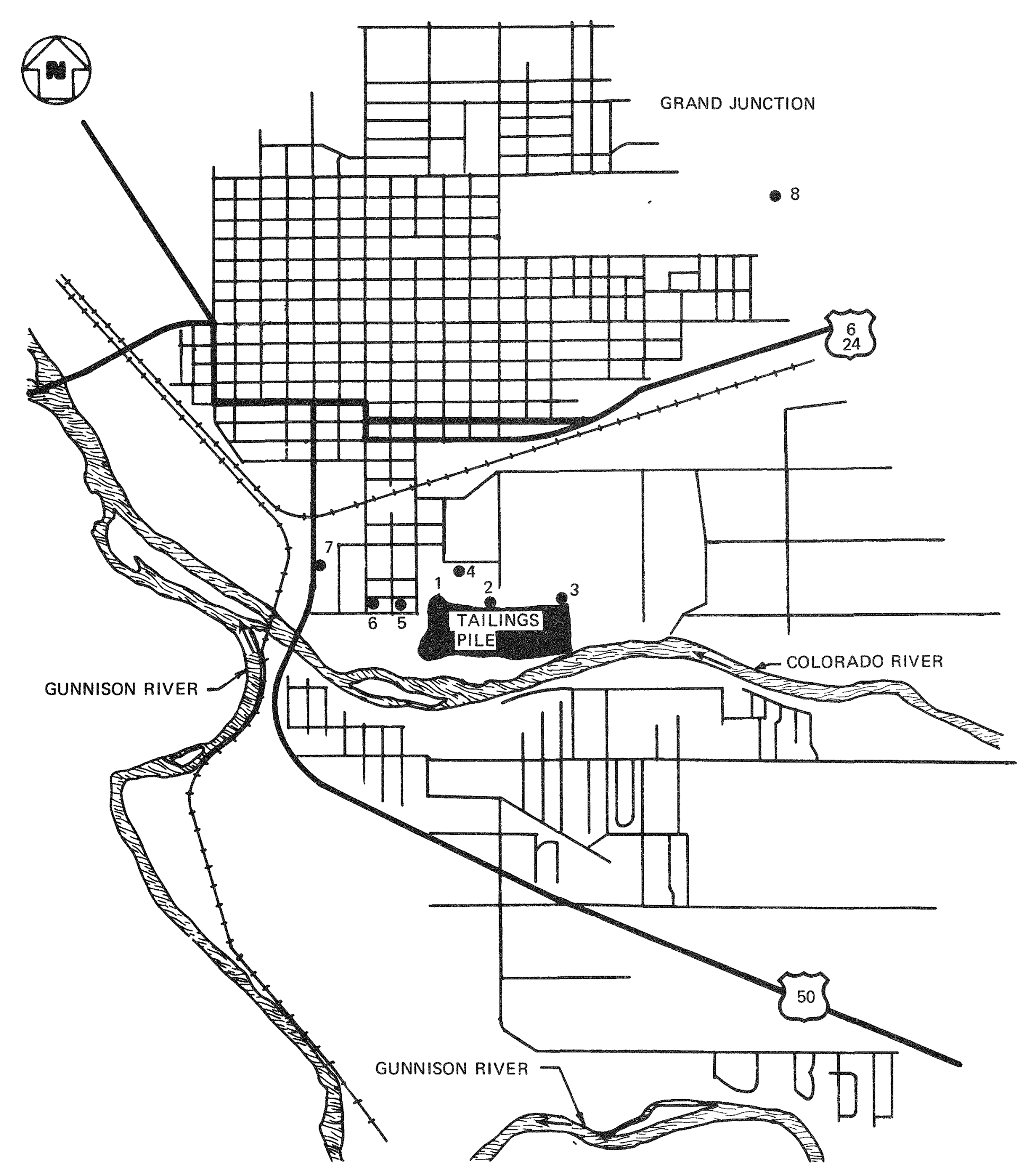

\begin{tabular}{|c|c|c|c|c|c|}
\hline $\begin{array}{l}\text { SITE } \\
\text { NO. }\end{array}$ & $\begin{array}{l}\text { 24 HRR } \\
\text { INDCOORR } \\
(\mathrm{pci} / 1)\end{array}$ & 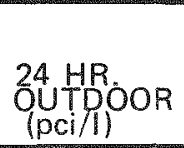 & $\begin{array}{l}\text { AVG } \\
\text { WIND } \\
\text { SPEED } \\
\text { (KNOTS) }\end{array}$ & $\begin{array}{l}\text { AVG } \\
\text { WVIND } \\
\text { DIREC } \\
\text { TION }\end{array}$ & LOCATION \\
\hline 1 & ND & 59 & 12 & $E$ & NW CORNER OF PILE \\
\hline 2 & ND & 42 & 10 & E & $\begin{array}{l}\text { BEHINPMMILL BLDG } \\
0.03 \text { MFPRM PILE }\end{array}$ \\
\hline 3 & ND & 27 & 10 & $\mathrm{E}$ & $\begin{array}{l}\text { BETWEEN PILE \& SEWAGE } \\
\text { PLANT-0.03 MI FROM PILE }\end{array}$ \\
\hline 4 & 3.9 & 6.2 & 10 & $\mathrm{NE}$ & $0.10 \mathrm{MIN}$ OF PILE \\
\hline 5 & ND & 6.7 & 12 & E & 0.08 MI WNW OF PILE \\
\hline 6 & 7.3 & 6.3 & 12 & $\mathrm{E}$ & 0.15 MI WNW OF PILE \\
\hline 7 & 3.9 & 2.6 & 10 & SE & $0.33 \mathrm{MI}$ WNW OF PILE \\
\hline $8^{*}$ & 5.8 & 1.5 & 12 & SE & 1.31 MI NE OF PILE \\
\hline
\end{tabular}

*TAILINGS LOCATION 

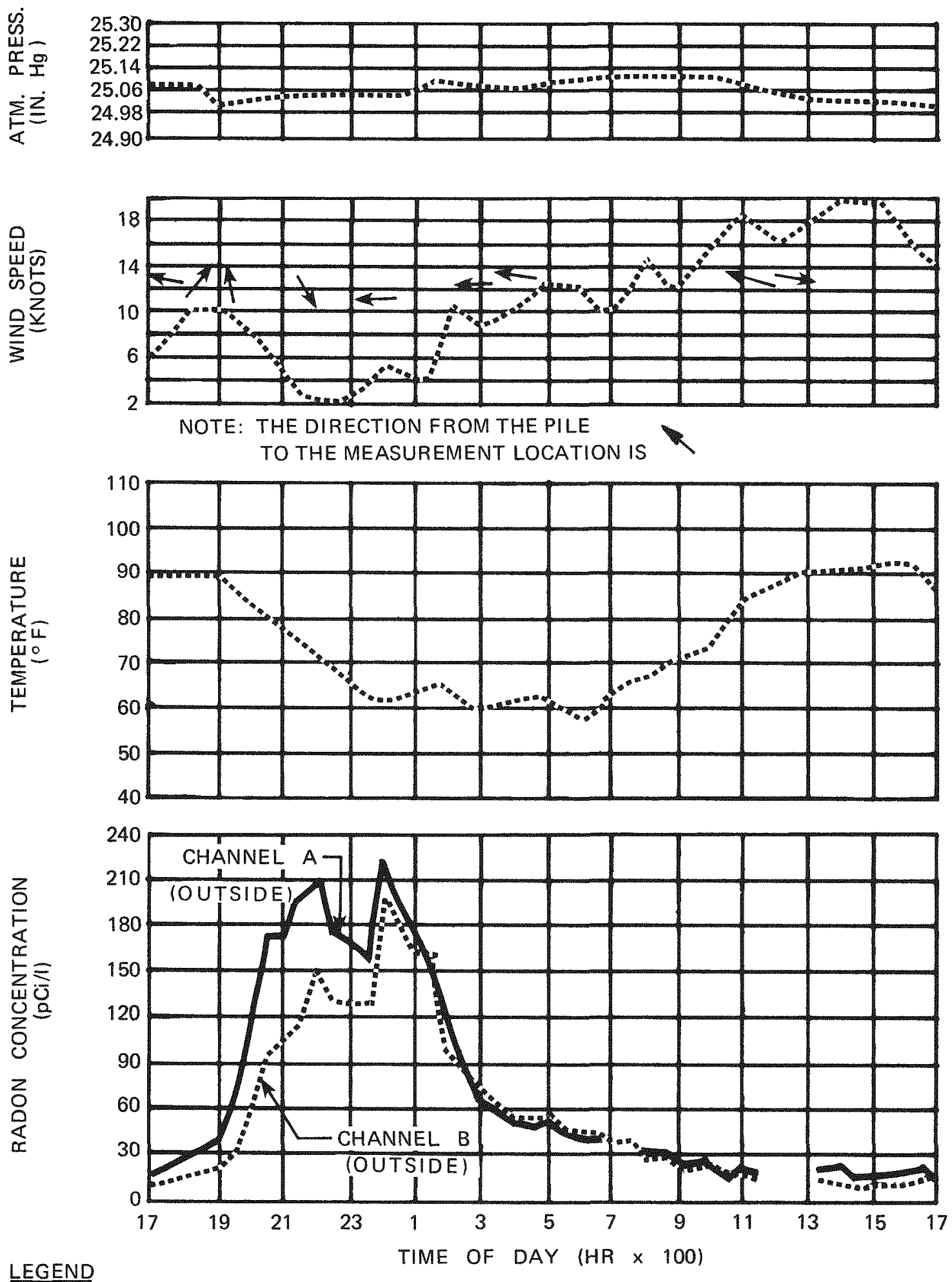

$\rightarrow$ WIND DIRECTION (Up = North, Down $=$ South)

FIGURE 3-5. ${ }^{222}$ Rn AND ATMOSPHERIC TRANSIENTS AT NW CORNER OF PILE ON JUNE 2, 1976 

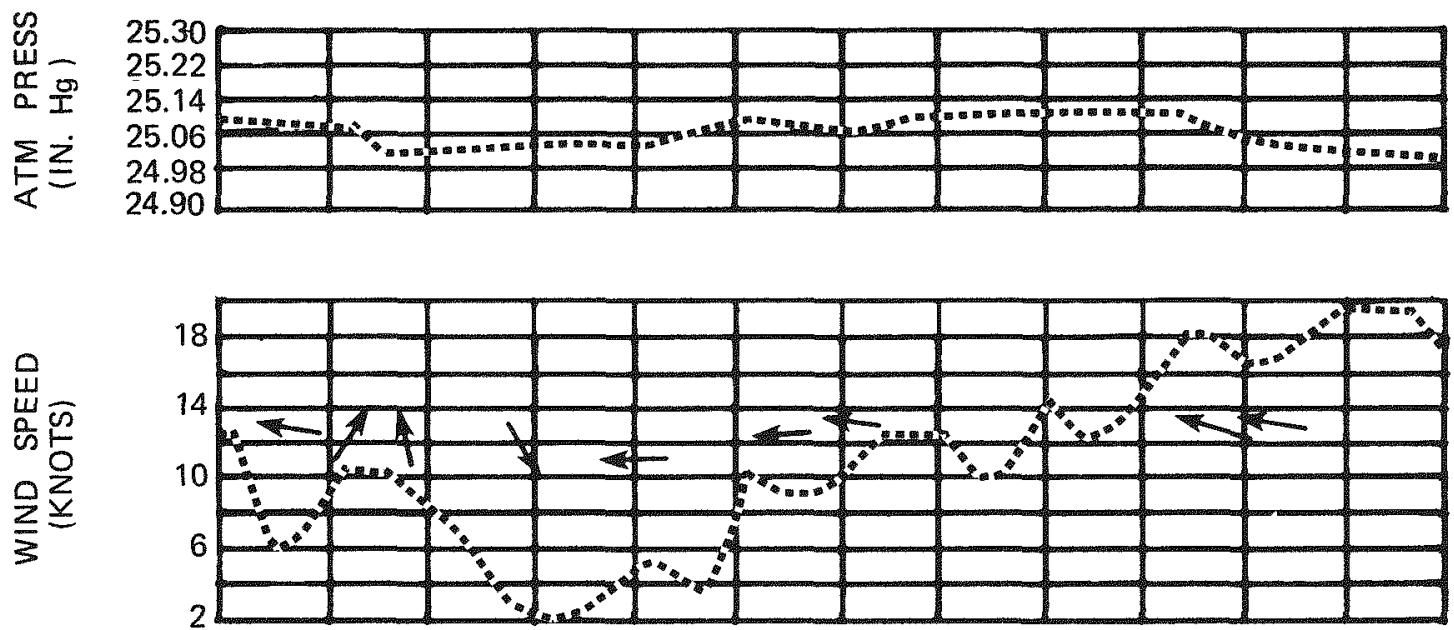

NOTE: THE DIRECTION FROM THE PILE TO THE MEASUREMENT LOCATION IS
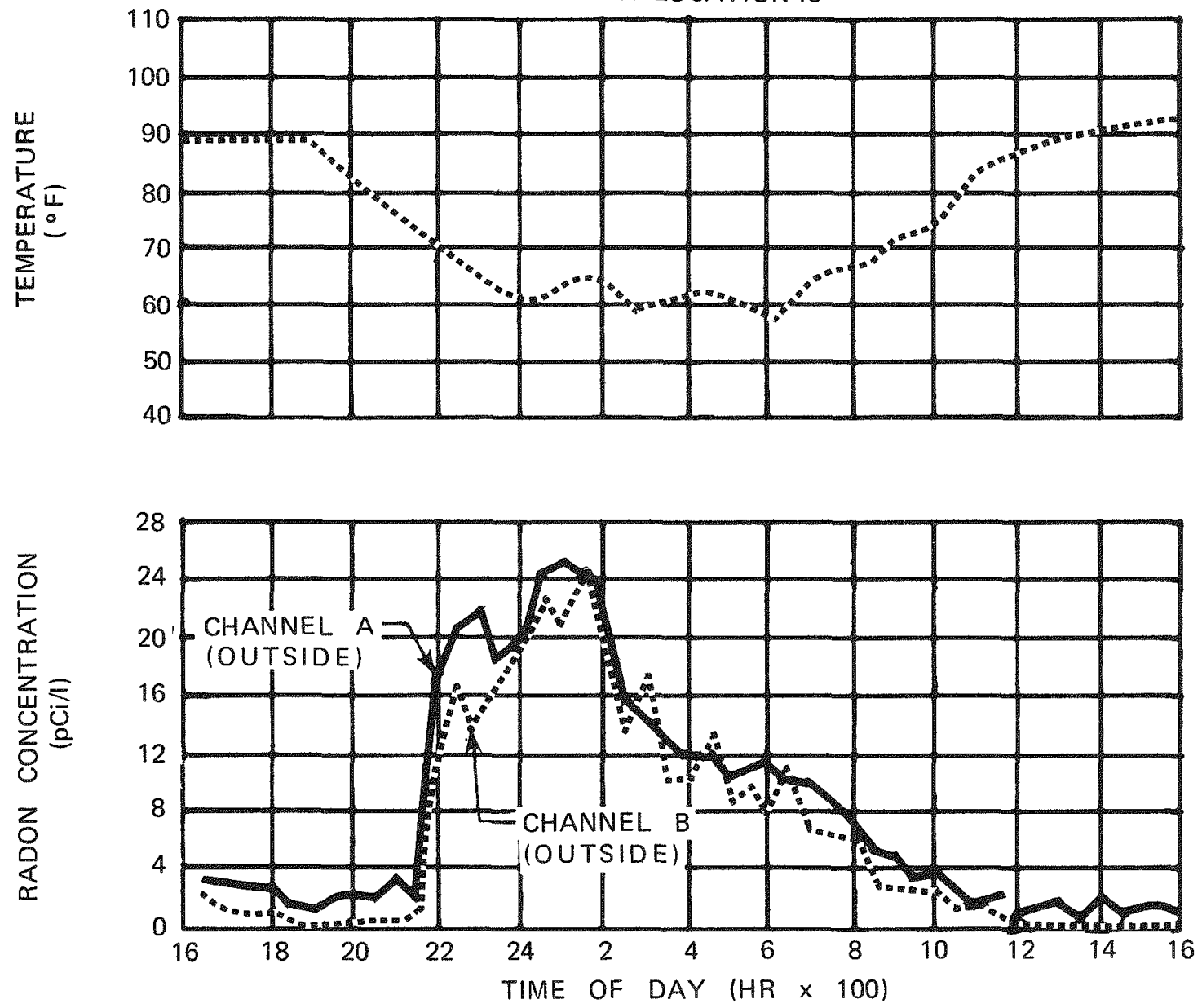

LEGEND

$\rightarrow$ WIND DIRECTION (Up = North, Down = South)

FIGURE 3-6. ${ }^{222}$ Rn AND ATMOSPHERIC TRANSIENTS 0.08 MI WNW OF PILE ON JUNE 2, 1976 


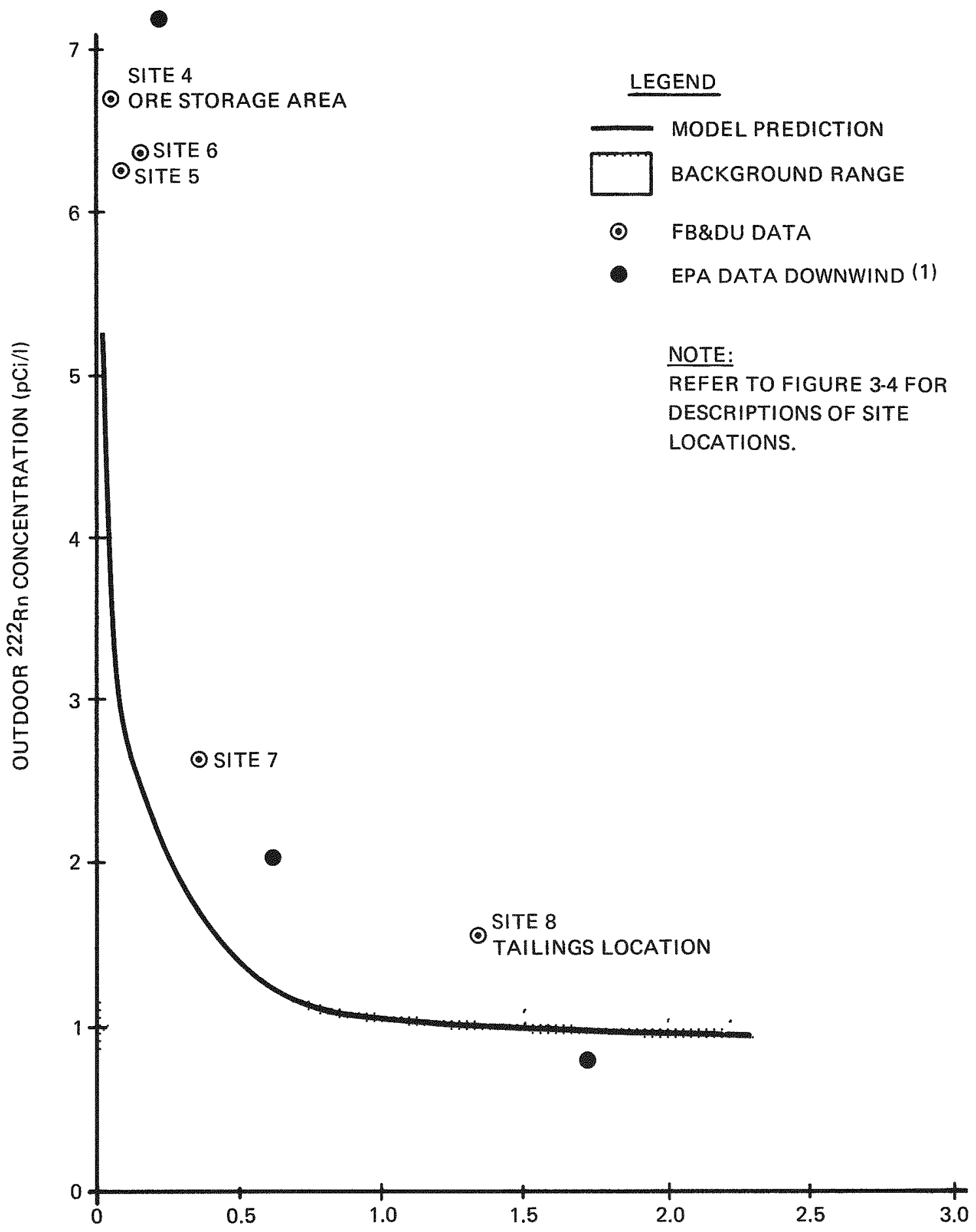

DISTANCE FROM EDGE OF TAILINGS PILE (MI)

FIGURE 3-7. REDUCTION OF OUTDOOR 222 Rn CONCENTRATION WITH DISTANCE FROM EDGE OF TAILINGS PILE 


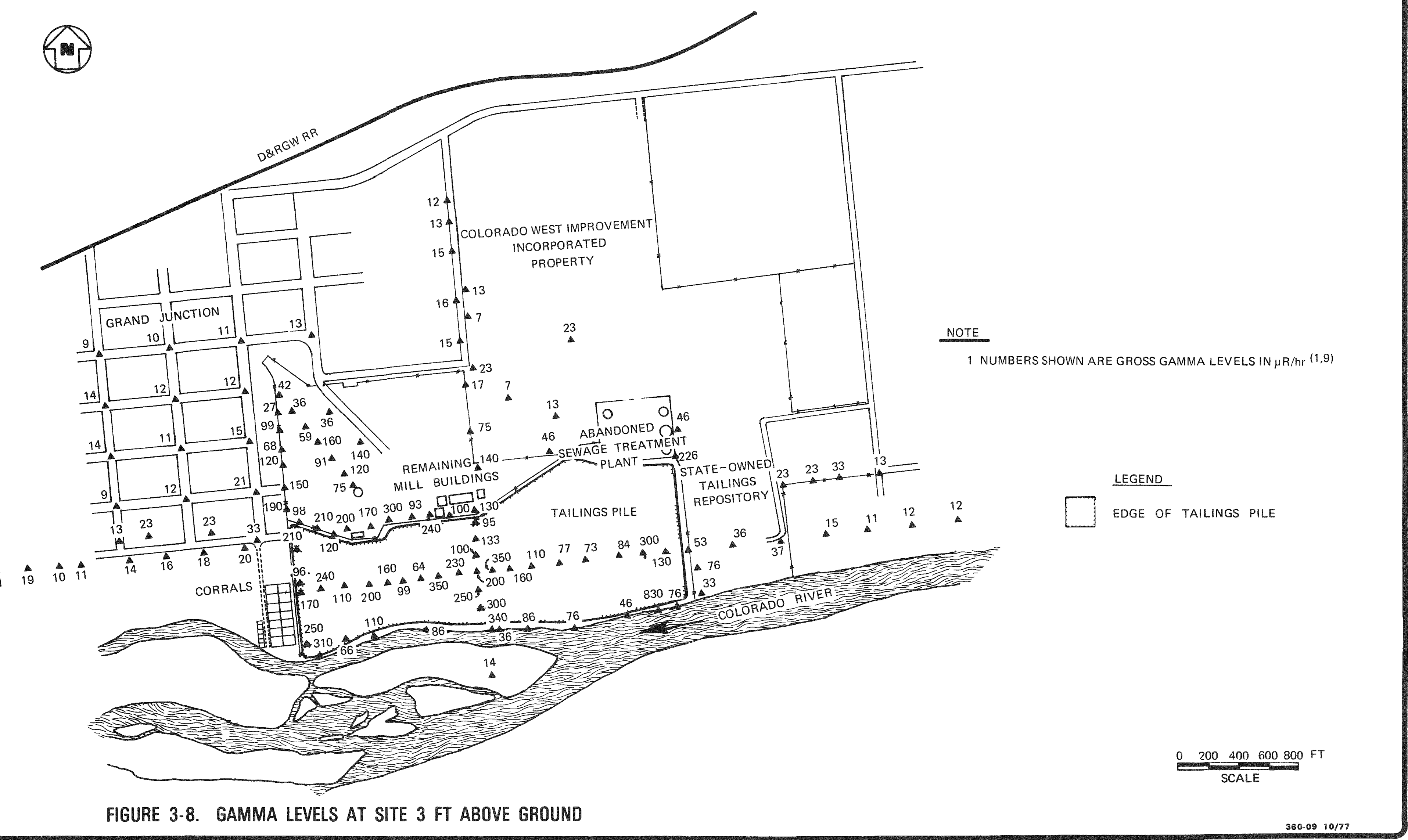




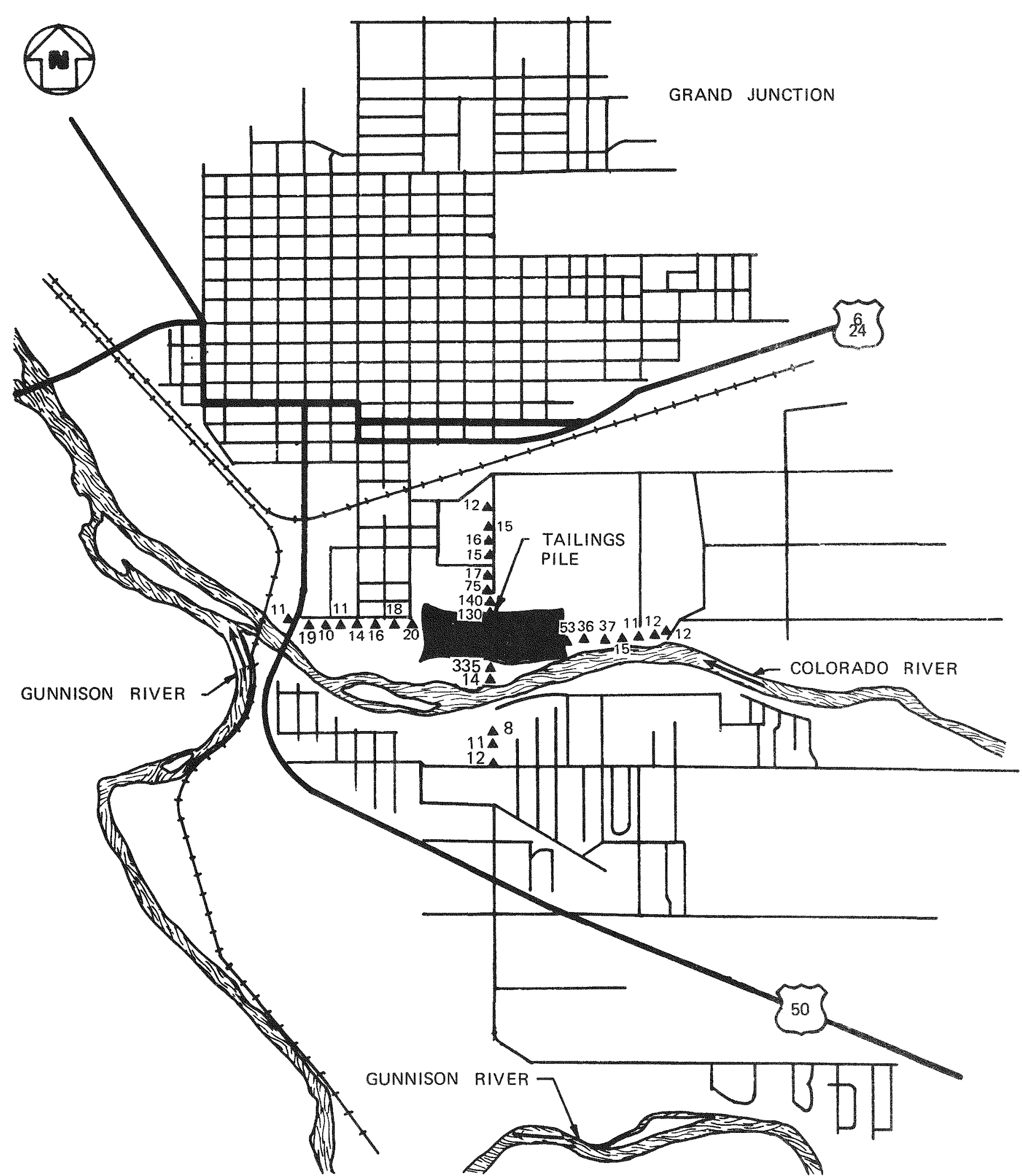

FIGURE 3-9. GAMMA LEVELS IN VICINITY 3 FT ABOVE GROUND

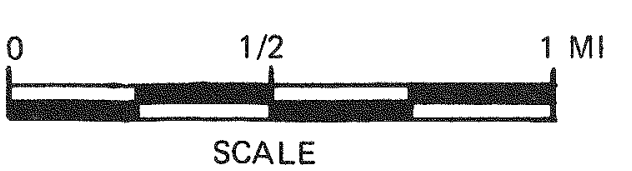




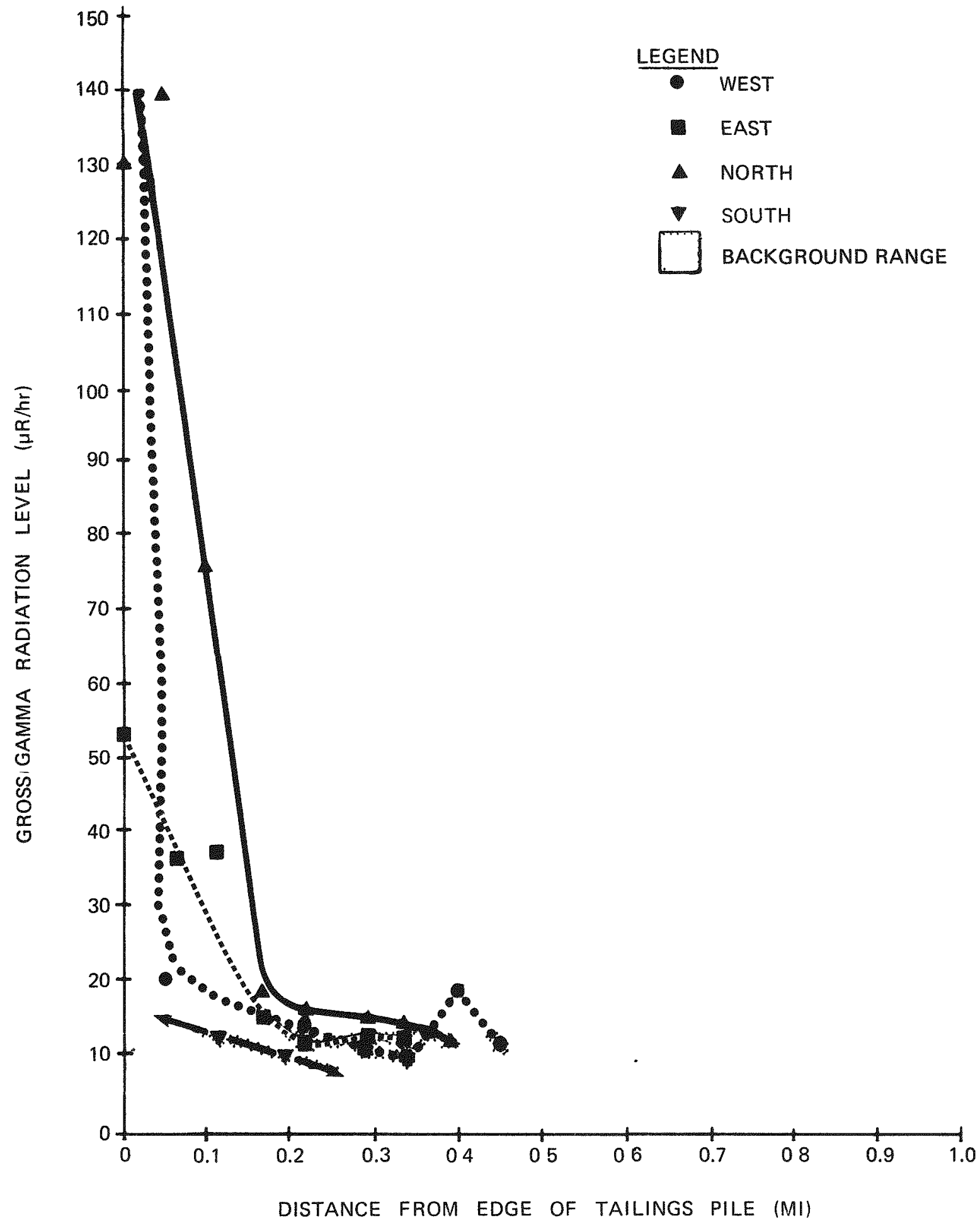

FIGURE 3-10. REDUCTION OF EXTERNAL GAMMA RADIATION LEVELS WITH DISTANCE FROM THE TAILINGS PILE 


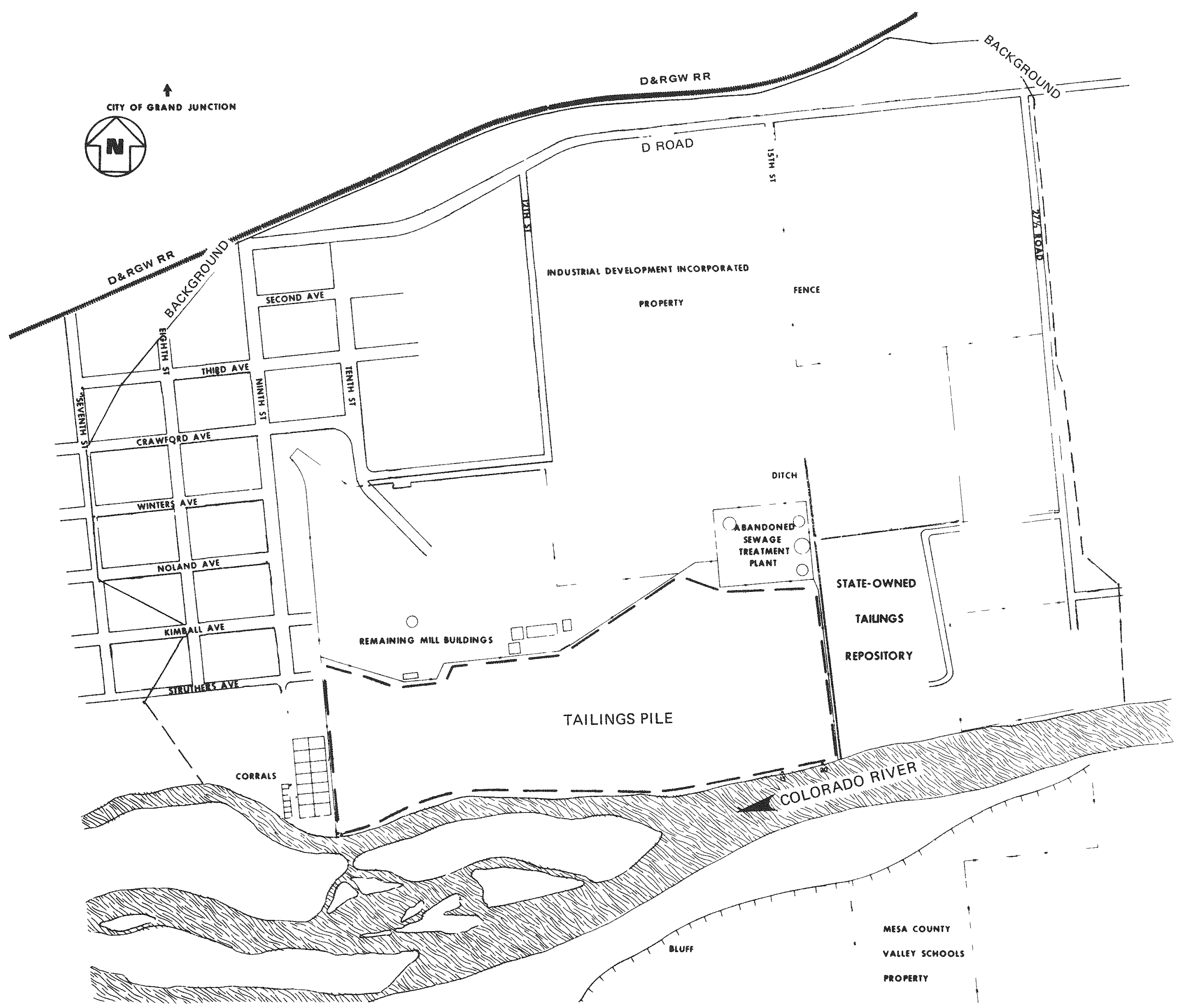

NOTE:

REFERENCE: TECHNICAL NOTE ORP/LV-75-5, GAMMA RADIATION SURVEYS AT INACTIVE URANIUM VEGAS, NEVADA, AUG 1975 FIG 4, PAGE 43 . 


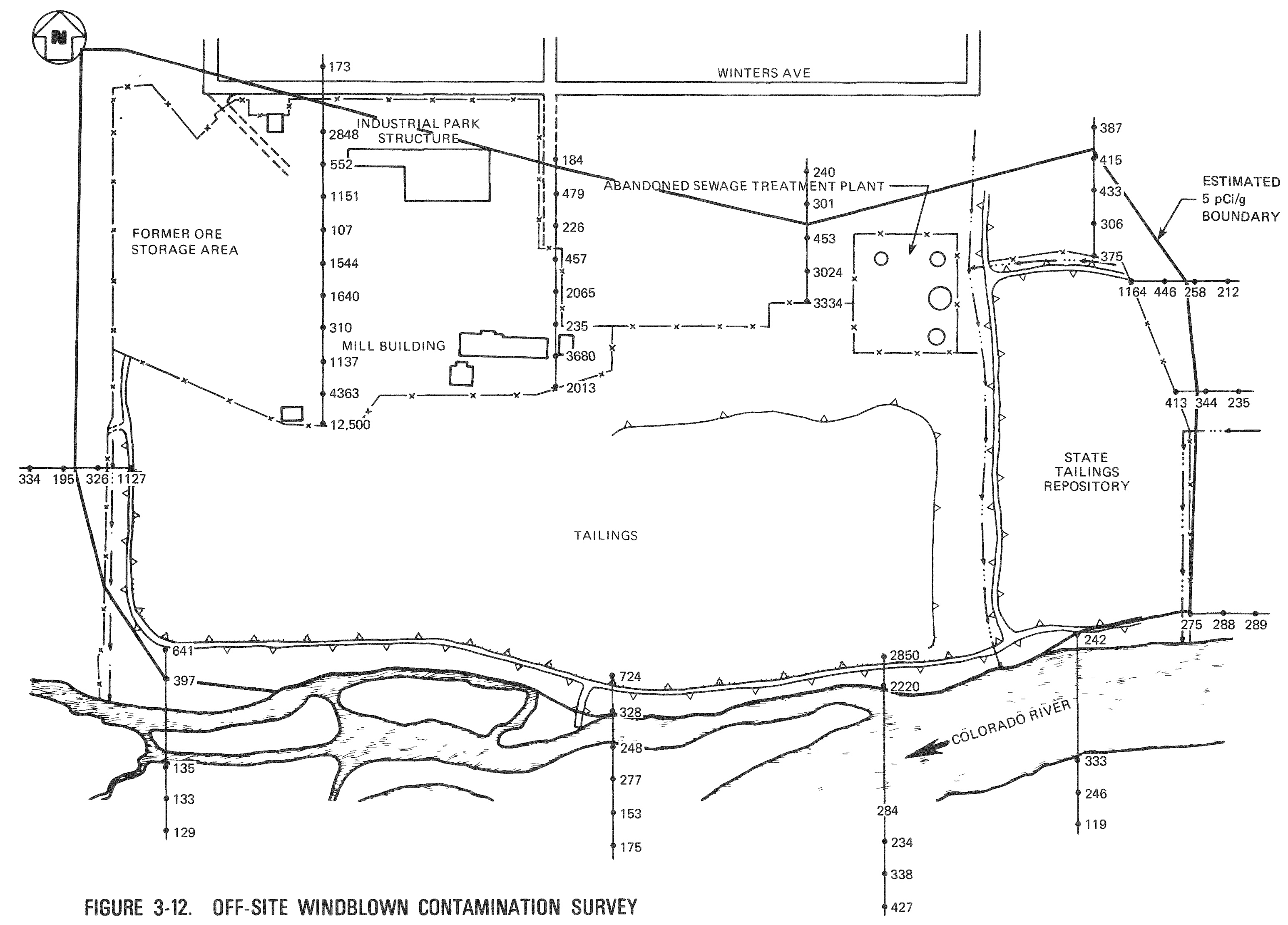

NOTES

1. MAP DEVELOPED FROM LOGGED MAY 7.1976

2. FIGURES SHOWN ARE 'DELTA' READINGS AS EXPLAINED IN PARAGRAPH 3.4.3.

LEGEND

3 EDGE OF TAILINGS

SUDDEN CHANGE IN
SLOPE (DOWNWARD)

- delta traverse

$\begin{array}{lllll}0 & 100 \quad 200 \quad 300 \quad 400 & 500 \mathrm{FT}\end{array}$ Soches SCALE 


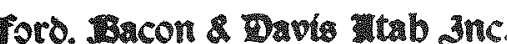

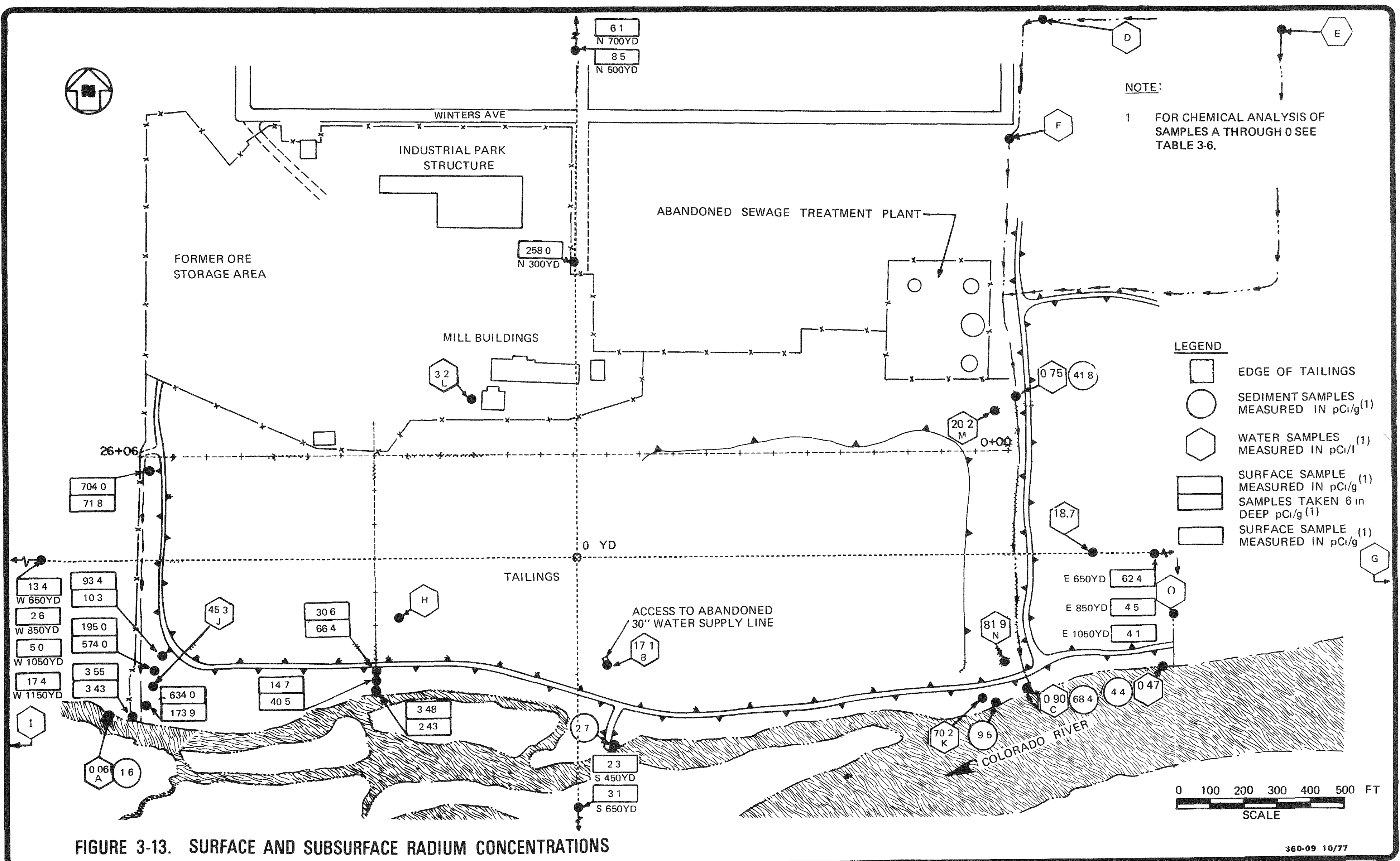




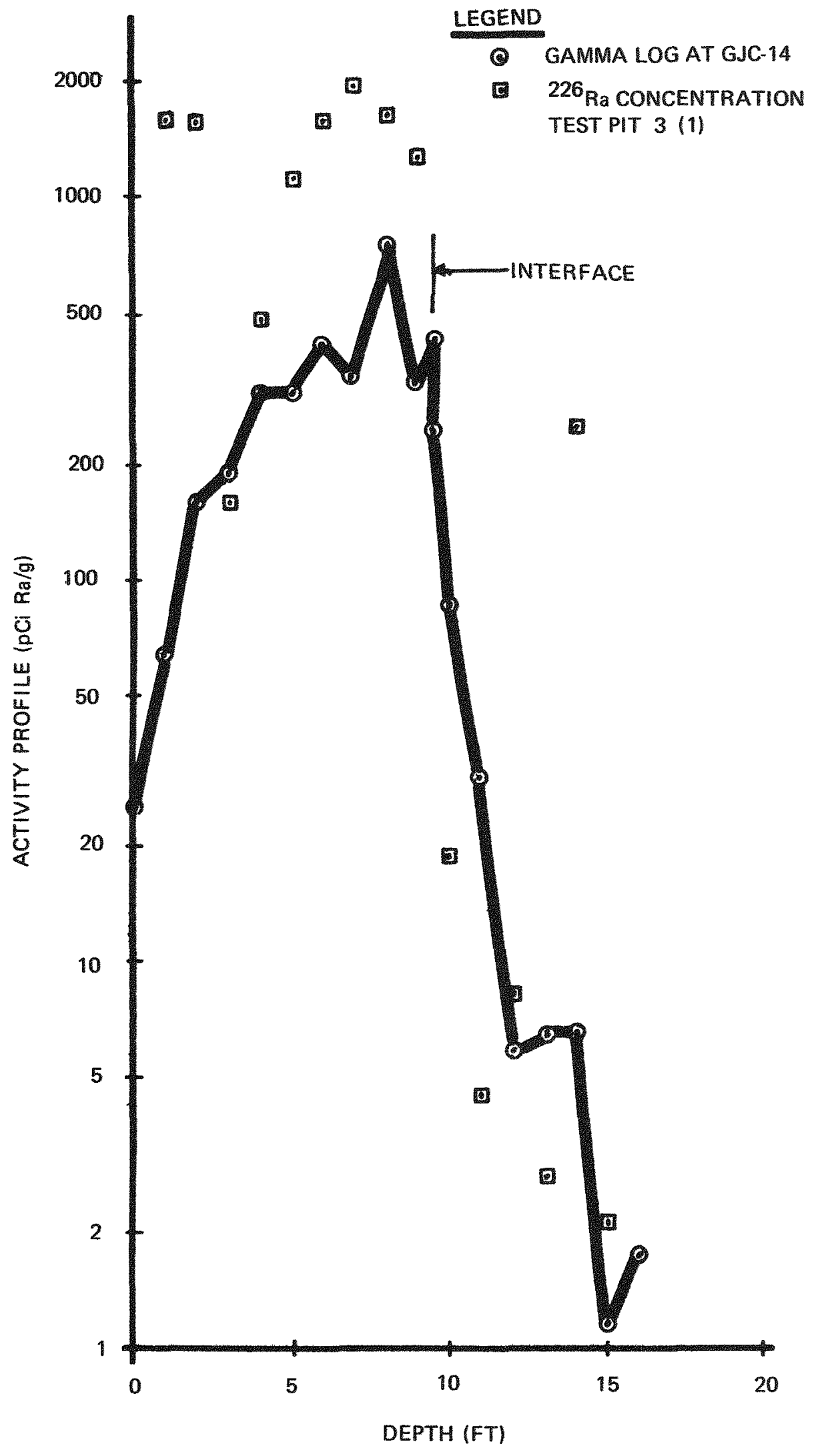

FIGURE 3-14. RADIOMETRIC PROFILE AT DRILL HOLE GJC-14 


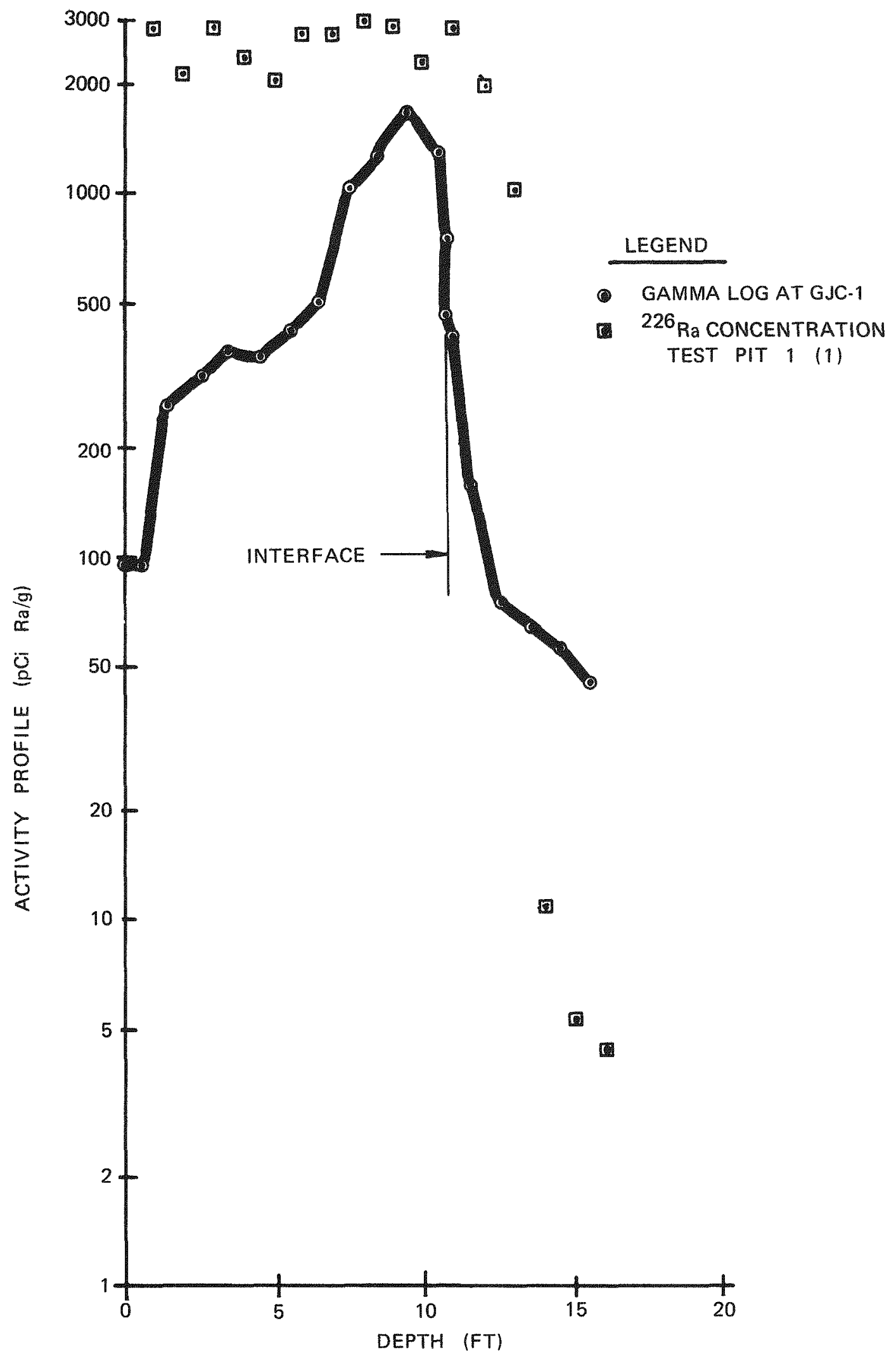

FIGURE 3-15. RADIOMETRIC PROFILE AT DRILL HOLE GJC-1 
Foro, 18acon \& Davis ab anc.

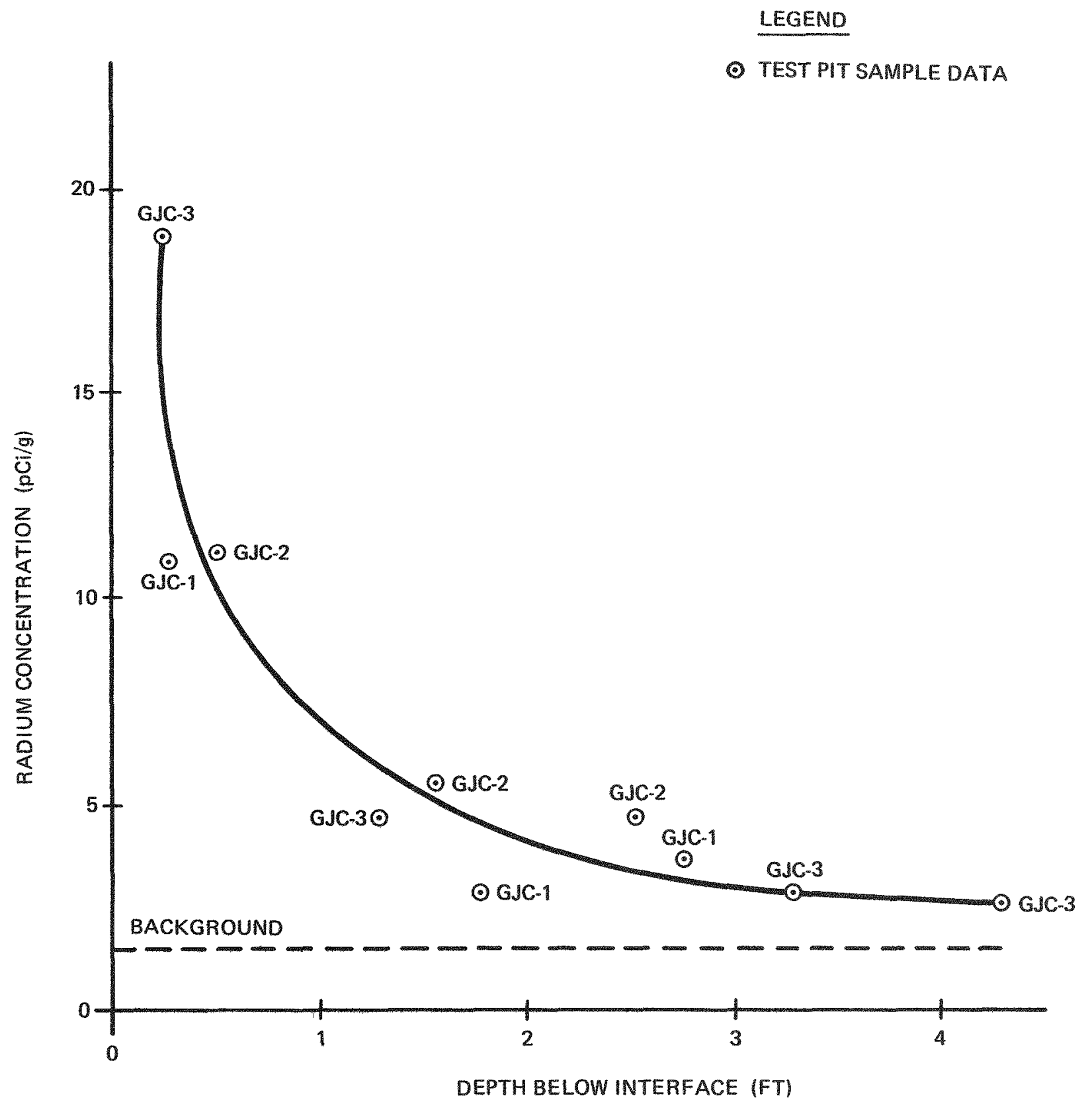

FIGURE 3-16. RADIUM ACTIVITY CONCENTRATION IN CONTAMINATED SUBSOIL 


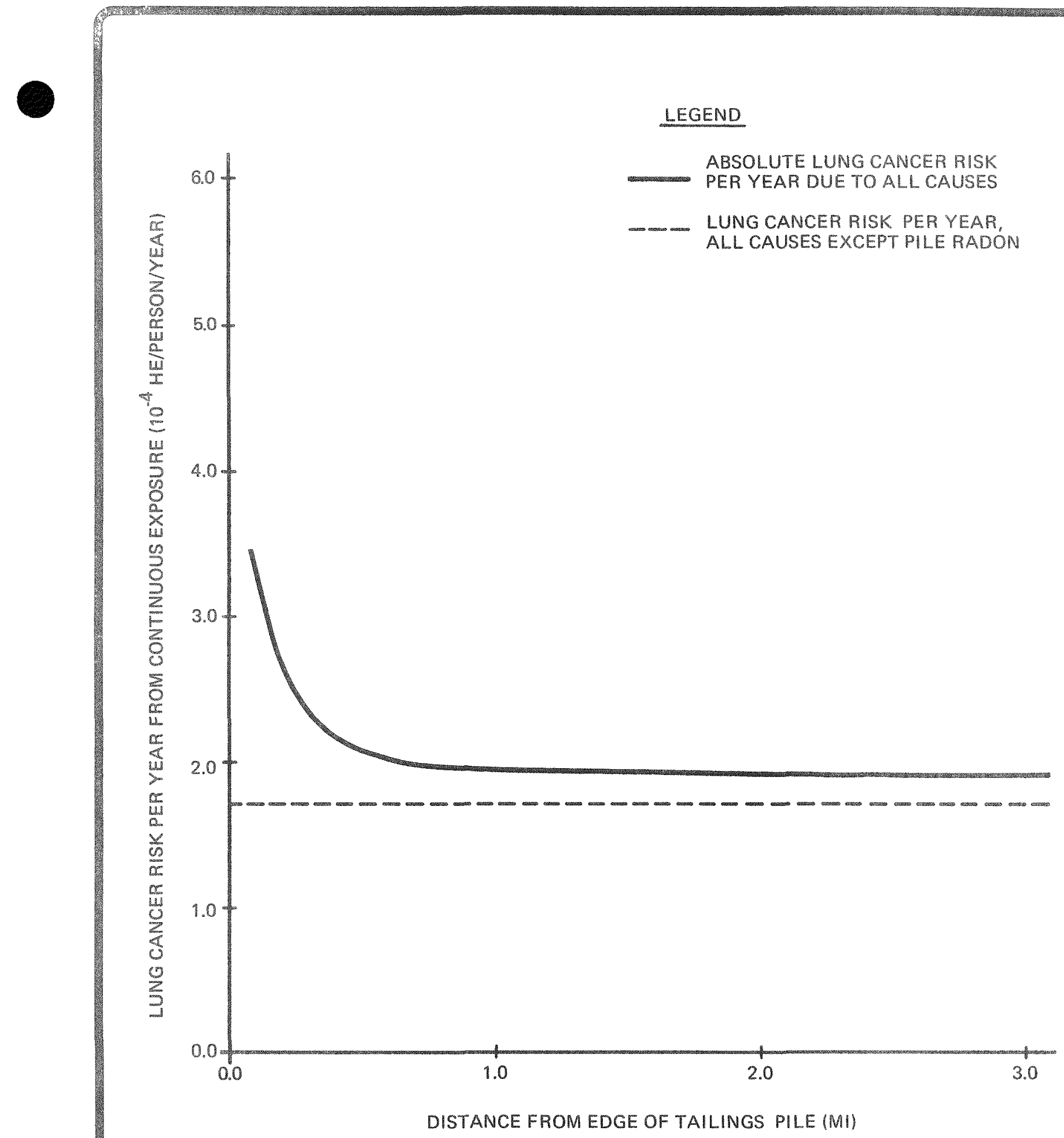

FIGURE 3-17. LUNG CANCER RISK FROM CONTINUOUS EXPOSURE TO RADON GAS 
TABLE $3-1$

NOTATIONS AND ABBREVIATIONS USED IN CHAPTER 3

Isotope - A particular type of element, differing by nuclear characteristics, identified by the atomic mass number given after the element name, e.g., Radium-226.

Isotope Abbreviations:

$$
\begin{aligned}
& 238_{\mathrm{U}}=\text { Uranium-238 } \\
& 234 \mathrm{Th}=\text { Thorium-234 } \\
& 232 \mathrm{Th}=\text { Thorium-232 } \\
& 234 \mathrm{~Pa}=\text { Proctactinium-234 } \\
& 226 \mathrm{Ra}=\text { Radium-226 } \\
& 222 \mathrm{Rn}=\text { Radon-222 } \\
& 218_{\mathrm{PO}}=\text { Polonium-218 } \\
& 214 \mathrm{~Pb}=\text { Lead-214 } \\
& 214 \mathrm{Bi}=\text { Bismuth }-214 \\
& 40_{\mathrm{K}}=\text { Potassium }-40
\end{aligned}
$$

Radiations:

alpha particle

beta particle

gamma rays

half-life $\left(\mathrm{T}_{1 / 2}\right)$

working level (WL)

one working level month (WLM) helium nucleus: easily stopped with thin layers of material. all energy deposited locally.

electron; penetrates about $0.2 \mathrm{~g} / \mathrm{cm}^{2}$ of material.

electromagnetic radiation; similar to $X$-rays, and highly penetrating.

time required for half the radioactive atoms to decay.

measure of potential alpha energy per liter of air from any combination of short-1ived radon daughters $\left(1 \mathrm{WL}=1.3 \times 10^{5} \mathrm{MeV}\right.$ of alpha energy).

exposure to air containing a RDC of 1 WL for a duration of $170 \mathrm{hr}$. 
TABLE $3-1$ (cont)

\begin{tabular}{|c|c|}
\hline roentgen $(R)$ & $\begin{array}{l}\text { that quantity of gamma } \\
\text { radiation which yields } \\
\text { a charge deposition of } \\
2.58 \text { x } 10-4 \text { coul/kg air. } \\
\text { This is equal to the energy } \\
\text { deposition of } 88 \text { ergs/g of } \\
\text { air or } 93 \text { ergs/g of tissue. }\end{array}$ \\
\hline$\mu R / h r$ & $10^{-6}$ roentgen/hr. \\
\hline rad & $\begin{array}{l}\text { energy deposition of } 100 \\
\text { ergs/g of material. }\end{array}$ \\
\hline picocurie (pci) & $\begin{array}{l}\text { unit of activity ( } 1 \text { pci }= \\
\text { o.037 radioactive decays } / \mathrm{sec} \\
\text { or } 2.2 \mathrm{~min}) \text {. }\end{array}$ \\
\hline $\mathrm{MeV}$ & $\begin{array}{l}\text { unit of energy: } 1 \mathrm{MeV}= \\
1.6 \times 10^{-6} \text { erg. }\end{array}$ \\
\hline rem & $\begin{array}{l}\text { unit of energy deposition in } \\
\text { man: } 1 \text { rem }=1 \text { rad } x \text { quality } \\
\text { factor; the quality factor } \\
20 \text { for alpha particles. }\end{array}$ \\
\hline
\end{tabular}

Note: Also see definitions of terms in Glossary. 
TABLE $\quad 3-2$

BACKGROUND RADIATION SOURCES IN SOIL FROM NORTHWEST COLORADO(I)

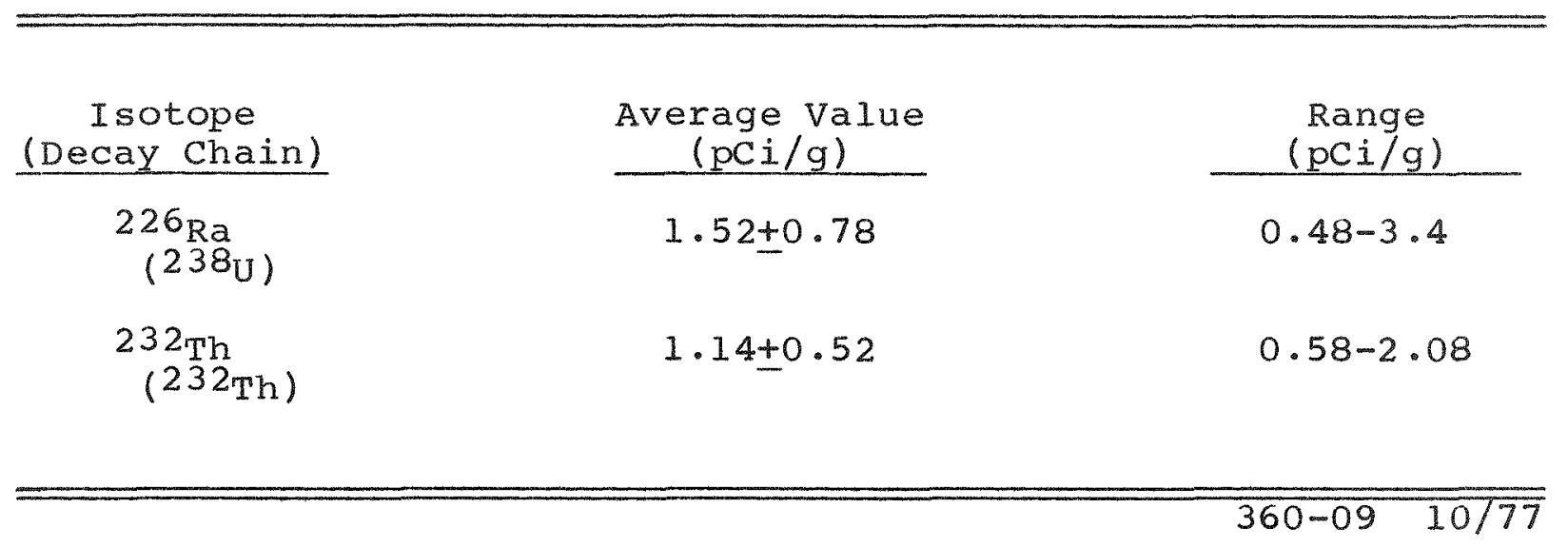


TABLE $3-4$

ESTIMATED HEALTH IMPACT FROM GRAND JUNCTION TAILINGS

FOR AN AREA O TO 0.75 MILE EROM TAILINGS EDGE

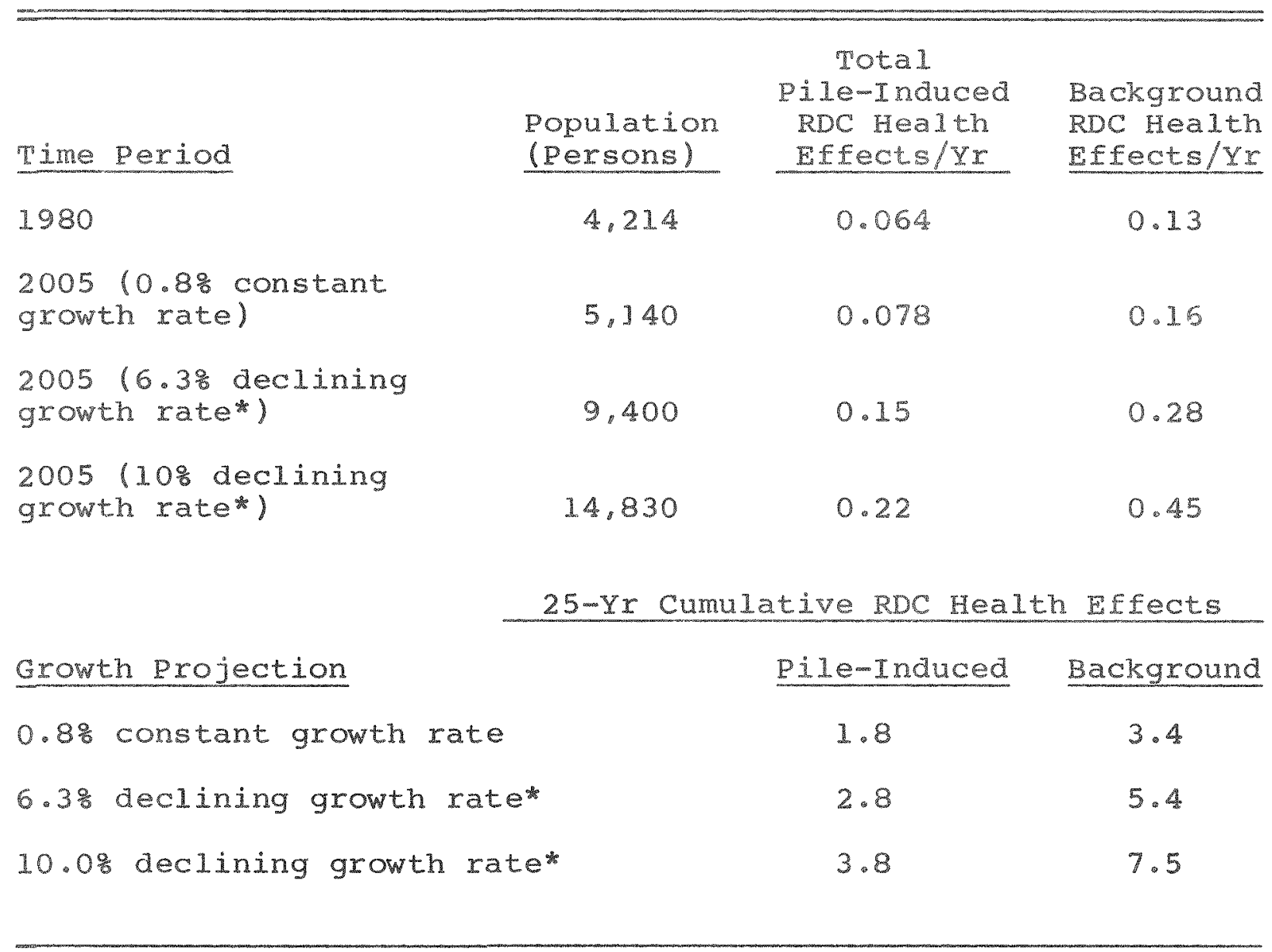

*Declines linearly from its initial value to zero in 25 yr and remains constant at zero thereafter. 
TABLE 3-5

ESTIMATED HEALTH IMPACT FROM GRAND JUNCTION TAILINGS

FOR AN AREA D TO 6 MILES FROM TAILINGS EDGE

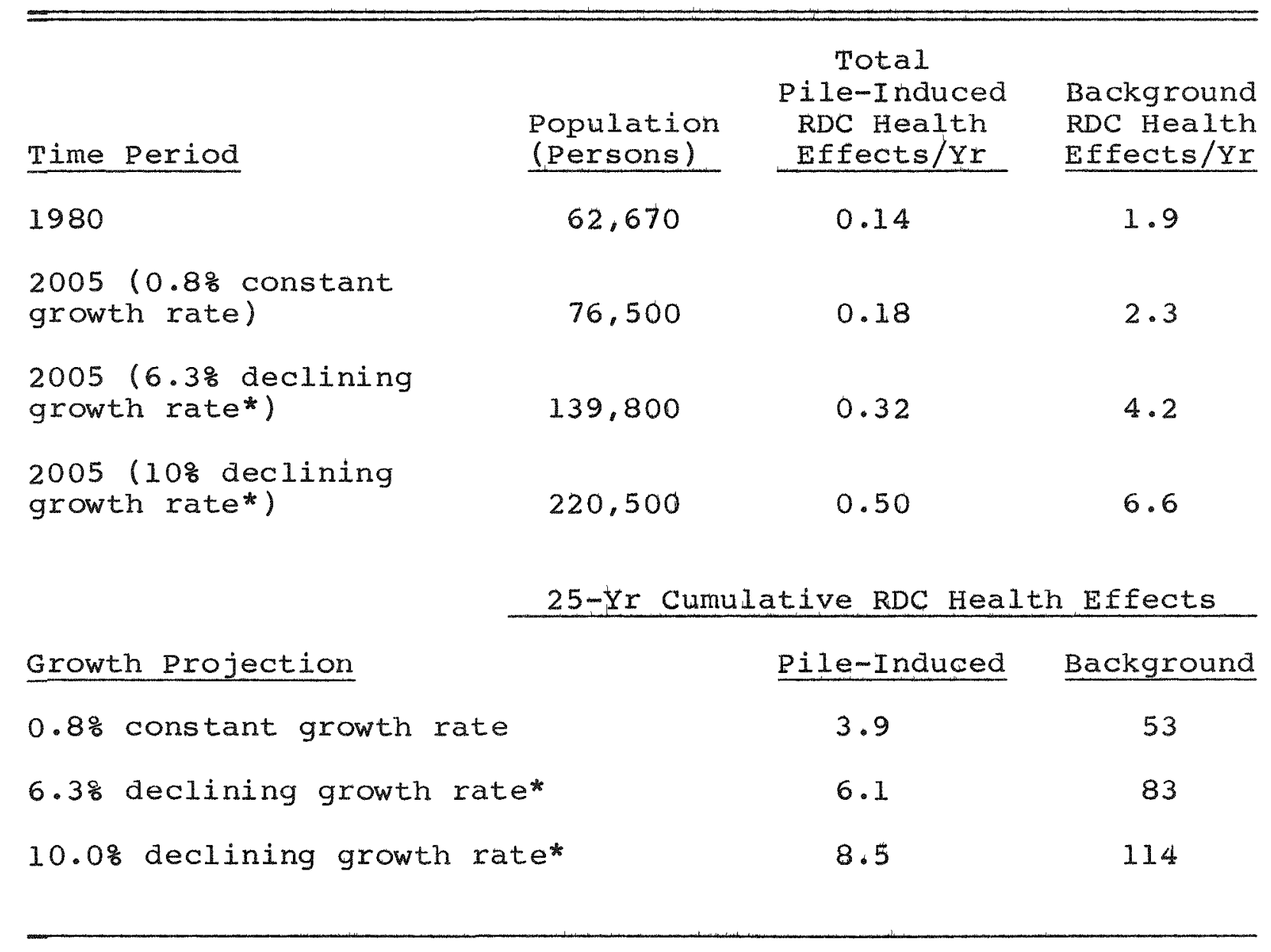

*Declines linearly from its initial value to zero in 25 yr and remains constant at zero thereafter. 
TABLE $3-6$

CHEMICAL ANALYSES OF GRAND JUNCTION WATER SAMPLES (mg/l)

\begin{tabular}{|c|c|c|c|c|c|c|c|c|c|}
\hline & $\underline{S a m p l e}^{\mathrm{a}}$ & As & $\mathrm{Ba}$ & $\mathrm{ca}$ & $\mathrm{Cr}$ & $\mathrm{V}$ & $\mathrm{Fe}$ & $\mathrm{Pb}$ & $\mathrm{Se}$ \\
\hline A & $\begin{array}{l}\text { - Colorado River at } \\
\text { SW corner of pile }\end{array}$ & $<0.001$ & 0.025 & $<0.001$ & 0.003 & 0.020 & 3.920 & 0.038 & 0.037 \\
\hline B & $\begin{array}{l}\text { - Opening into water } \\
\text { flume under tailings } \\
\text { pile }\end{array}$ & 0.135 & 0.013 & 0.014 & 0.018 & 0.040 & 1.033 & 0.813 & 1.340 \\
\hline C & $\begin{array}{l}\text { - Ditch at SE corner } \\
\text { of pile }\end{array}$ & $<0.001$ & 0.018 & $<0.001$ & 0.009 & 0.120 & 1.420 & 0.051 & 0.313 \\
\hline $\mathrm{D}$ & - Ditch NE of pile & $<0.001$ & 0.007 & $<0.001$ & 0.011 & $<0.001$ & 1.180 & 0.050 & 0.076 \\
\hline $\mathbf{E}$ & - Ditch NE of pile & $<0.001$ & 0.019 & $<0.001$ & 0.012 & $<0.001$ & 1.430 & 0.048 & 0.070 \\
\hline F & - Ditch NE of pile & $<0.001$ & 0.010 & $<0.001$ & $<0.001$ & $<0.001$ & 3.230 & 0.027 & 0.055 \\
\hline G & $\begin{array}{l}\text { - Colorado River } \\
\text { upstream from pile } \\
\text { (off map) }\end{array}$ & $<0.001$ & 0.014 & $<0.001$ & $<0.001$ & $<0.001$ & 2.070 & 0.044 & 0.048 \\
\hline $\mathrm{H}$ & $\begin{array}{l}\text { - Drill hole in SW } \\
\text { quadrant of tailings } \\
\text { pile }\end{array}$ & 0.73 & 0.073 & 0.045 & 0.148 & 3.55 & 75.0 & 0.219 & 0.04 \\
\hline I & $\begin{array}{l}\text { - Colorado River } \\
\text { downstream from pile } \\
\text { (off map) }\end{array}$ & $<0.001$ & 0.018 & $<0.001$ & 0.014 & $<0.001$ & 4.22 & 0.05 & 0.077 \\
\hline $\mathrm{J}$ & - Drill hole SW of pile & 0.630 & 0.121 & 0.018 & 0.205 & 0.470 & 117.0 & 2.390 & 0.032 \\
\hline
\end{tabular}


TABLE 3-6 (Cont)

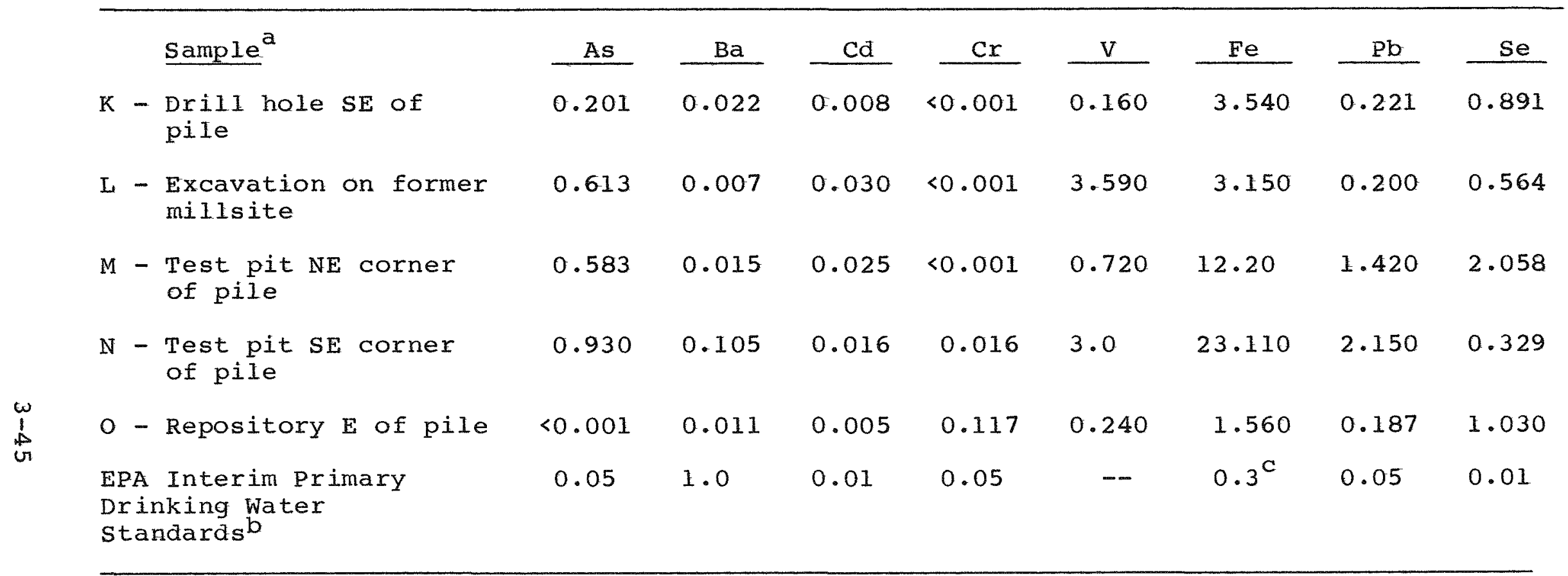

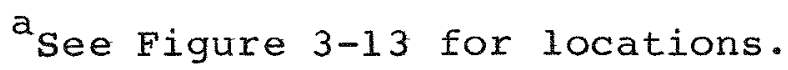

bederal Register, December 24, 1975

$\mathrm{C}_{\text {Recommended }}$ imit from Manual for Evaluating Public Drinking Water Supplies, U.S. Public Health Service, 1969 
1. F.F. Haywood, et al.; "Assessment of the Radiological Impact of the Inactive Uranium Mill Tailings at Grand Junction, Colorado"; ORNL-5457; Oak Ridge National Laboratory, Oak Ridge, Tennessee; Apr 1980.

2. S.D. Shearer, Jr., and C.W. Sill, "Evaluation of Radon-222 Near Uranium Tailings Piles"; HEW DER 69-1; Mar 1969.

3. D.L. Duncan, G.A. Boysen, L. Grossman, and G.A. Franz; "Outdoor Radon Study (1974-1975): An Evaluation of Ambient Radon-222 Concentration in Grand Junction, Colorado": Technical Note ORP/LV-77-1; EPA, Office of Radiation Programs; Las Vegas, Nevada; Apr 1977.

4. D.T. Oakley; "Natural Radiation Exposure in the United States": EPA Report ORP/SIO-72-1; June 1972.

5. R.J. Countess; "222Rn Flux Measurements with a Charcoal Canister"; Health Physics; Vol 31; p. 455; 1976.

6. M.E. Wrenn, H. Spitz, and N. Cohen; "Design of a Continuous Digital-output Environmental Radon Monitor"; IEEE Transactions on Nuclear Science; Vol NS-22; Feb 1975.

7. D.H. Slade, ed.; Meteorology and Atomic Energy 1968 ; TID-24190; AEC; July 1968.

8. G.A. Franz; Colorado Department of Health, Grand Junction, Colorado; private communication; June 1976.

9. R.L. Douglas and J.M. Hans, Jr.; "Gamma Radiation Surveys at Inactive Uranium Mill Sites"; Technical Note ORP/LV75-5; EPA; Las Vegas, Nevada; Aug 1975.

10. D. Lamodin and L.J. Dymerski; "Progress Report: Uranium Mill Tailings study, Phase II"; NCRH/HEW; May 1967.

11. "Phase I Reports on Conditions of Inactive Uranium Mi11sites, Grand Junction Report"; AEC; Grand Junction, Colorado; oct 1974 .

12. "Radiological Criteria for Decontamination of Inactive Uranium Mill Sites, Phase I"; USEPA/ORP; Washington, D.C.; Dec 1974.

13. F.F. Haywood, et a1.; "Assessment of Radiological Impact of the Inactive Uranium Mill Tailings pile at salt Lake City, Utah"; ORNL-TM-5251 (NOV 1977). 
14. A.J. Breslin and H. Glauberman; "Uranium Mill Tailings Study"; AEC Technical Memorandum; HASL-64-14; July 1964.

15. "Phase II- Title I, Engineering Assessment of Inactive Uranium Mill Tailings, Vitro site, Salt Lake City, Utah"; GJT-I; FB\&DU; Apr 1976 .

16. A.K.M.M. Haque and A.J.L. Collinson; Health Physics: Vol 13, p. 431; 1967.

17. "The Effects on Populations of Exposure to Low Levels of Ionizing Radiation: 1980"; Report Advisory Committee on Biological Effects of Ionizing Radiation, NAS, Natl. Res. Council; 1980 .

18. B.L. Cohen; "The BEIR Report Relative Risk and Absolute Risk Models for Estimating Effects of Low Level Radiation"; Health Physics 37, 509; 1979.

19. "Indoor Radiation Exposure Due to Radium-226 in Florida Phosphate Lands"; U.S. Environmental Protection Agency; Washington, D.C.; EPA 520/4-78-013; July 1979.

20. Statistical Abstract of the United States; looth Edition; p. 29, Table 29 .

21. "Health Effect Risk Estimators for Radon Daughters"; report to Ford, Bacon \& Davis Utah, Inc., by Rogers and Associates Engineering Corp.; Jan 1981.

22. Grand Junction Census Data, preliminary figures; 1980.

23. J.L. England; "Impact of the Uranium Tailings Site on Land Use and Land Values: Grand Junction, Colorado"; Center of Health and Environmental Studies, Brigham Young University, Provo, Utah; 1976 .

24. Vital Statistics of the U.S.; Vol II; Mortality; National Center for Health Statistics; HEW; 1968. 
CHAPTER 4

SOCIOECONOMIC AND LAND USE IMPACTS 
The city of Grand Junction is located on the banks of the colorado River, which flows through Grand valley in a southwesterly direction and joins the Gunnison River $0.75 \mathrm{mi}$ downstream of the tailings. Grand Junction is the commercial, agricultural, transportation, and political center of western Colorado; it is the county seat of Mesa County and the largest city on colorado's "Western slope". The city is linked to Denver and Salt Lake City by Interstate 70, by U.S. Highway 50, by the Denver and Rio Grande Western Railroad, and by commercial airlines. rhe boundaries of Mesa county are shown in Figure 4-1.

\subsection{SOCIOECONOMIC BACKGROUND}

Grand Junction was settled relatively late in the history of the western United states (the early 1880's), but rapidly grew in importance when the railroad reached the town. In 1883 Grand Junction was declared the county seat of the newly formed Mesa County.

Mesa County has shifted from being primarily dependent upon agriculture ( $36 \%$ in 1940) to a more balanced economic base (7\% agriculture, 8\% construction, 10\% manufacturing, and 9\% higher education, in the early 1970's). Although Mesa County remains rural in its geography and land use, it is the region's commercial center because of the city of Grand Junction, which comprises more than one third of the county population. Grand Junction is the marketplace for ranching and agricultural products and the service center for the western slope of Colorado, southeastern Utah, and northwestern New Mexico. Mesa college, the region's 4-yr educational center, had an enrollment of 3,000 students in 1976. Grand Junction also has recently become a tourist center.

The future demographic and economic conditions of Grand Junction can be projected by extrapolating statistical data obtained for the four census records of 1940 through 1970.(1) The population of Grand Junction experienced a steady though gradual growth pattern until the $1950^{\circ} \mathrm{s}$, at which time there was an acceleration of population growth, to $29 \%$ for the decade $(2.6 \% / y r)$. There appeared to be a leveling of population in the $1960^{\circ} \mathrm{s}$, but current population estimates indicate an acceleration of growth after 1970.

Telephone connections are an indication of population. The annual rate of increase in connections for 1970 to 1973 was 2 to $3 \%$. However, for 1974 the rate grew dramatically 
to 9 to $10 \%$. (1) The preliminary 1980 census indicated the population of Grand Junction to be $27,071 .(2)$

The median age, $32 \mathrm{yr}$, of residents of Mesa county and Grand Junction is high for colorado and has remained virtually constant since 1940. The percentage of female population has increased from $51 \%$ in 1940 to $53 \%$ in 1970.

Ethnically, the population is made up of about $90 \%$ Caucasian, 9\% Spanish-American, and less than 1\% Black Americans or American Indians.(3)

The average income per household in December 1978 was estimated to be $\$ 13,750 / \mathrm{yr}$. The major sources of income for Grand Junction are manufacturing, trade, and agriculture. Most workers are now employed as professionals, managers. administrators, clericals. craftsmen, and service workers. Farmers and farm laborers show a consistent decline in both real numbers and percentage of the total. Professionals and service workers have increased in percentage and number since 1940.

Projections for the future of Grand Junction suggest vigorous growth over the next few years. The major factors that influence growth include energy exploration and development, and associated support facilities. The region is richly endowed with coal, oil shale, tar sands, and uranium, which are becoming very important to the local economy.

\subsection{POPULATION ESTIMATES}

Mesa County Planning officials and the Grand Junction Chamber of Commerce agree with the preliminary 1980 census(2) totals of 27,071 as the current population for the city of Grand Junction and 62,670 for the urban area within $6 \mathrm{mi}$ of the tailings pile.

The Colorado West Area Council of Governments projects that the population of the city of Grand Junction will increase to 38,400 people by 1985 and 61,300 by the year 2000.(3) These figures are based on a normal population projection without the development of large energy facilities or other major activities in the area. However, the same report projects that the population of the city of Grand Junction will reach 42,100 people by 1985 and 66,400 by the year 2000 if the proposed coal and oil shale developments are pursued. (3)

Several factors must be considered in determining population projections and future growth patterns for the Grand Valley area. Water to support extensive growth is linited. Although there are plans to expand the commerce and service sections of the city's economy, extensive industrialization will be hampered by the relative isolation of the area. Tourism will cause modest population growth, but major growth in the next 50 yr depends on the developmeni of energy resources. 
Figure 4-2 shows three possible population projections for Grand Junction and its vicinity. The least optimistic projection is a $0.8 \%$ constant annual growth rate, based on the growth rate of the U.S. as a whole. If this growth pattern were experienced, the population of the area would increase by 0.88 each year and reach a total of 76,500 persons by the year 2005 .

The most optimistic projection, a 108 declining annual growth rate, is also derived from Reference 1. If this growth projection were experienced, the population of the area would double in 10 yr and reach a maximum of 220,500 persons by 2005 .

The 6.3 declining growth rate was determined from the actual growth of the Grand Junction Census Division from 1970 to 1980. This projection assumes that the annual growth rate of the area will decline linearly from its initial rate of 6.38 to zero growth after $25 \mathrm{yr}$. The population in the year 2005 would be approximately 139,800 persons under this growth pattern.

An area within a 6 -mi radius of the site was divided azimuthally and radially, and the population of each node estimated. Table 4-1 lists the estimated 1980 population distribution based on 1970 and 1980 census data(3) and Reference 1.

4.3 LAND USE

As shown in Figure 4-3, the city of Grand Junction is characterized by five land use patterns: residential, commercial, services/recreational, industrial, and agricultural/vacant.

The area adjacent to the tailings on the north is either industrial or is in transition from the agricultural/vacant to the industrial category. An industrial park is being developed by colorado West Improvement, Inc., on land immediately north of the site, between the tailings and the D\&RGW Railroad. The industrial area extends north of the railroad and forms an industrial band on both sides of the railroad property. There is a residential concentration just northwest of the tailings site comprised mostly of old single-family dwellings. The area northeast of the site is used primarily for agricultural purposes. The commercial area of town is located north of the industrial section in a modern, compact business district. Residential areas and several small parks and a park-golf course complex extend north and east of the commercial district.

The Colorado River forms the southern boundary of the site. Two public schools are located on the south bank of the river, almost due south of the tailings and within $0.5 \mathrm{mi}$ of the site. The schools serve residential areas that consist primarily of newer housing and some areas that are currently under development. 
Adjacent to the tailings pile on the east side are 40 acres of land owned by the state of colorado. This land is being used as a repository for tailings and contaminated earth gathered during the Grand Junction remedial action program.

Adjacent to the west edge of the tailings pile there are several older single-family dwellings that are occupied at the present time. Many new homes have been built south of the Colorado River, but zoning of the area for industrial purposes prohibits construction of residences in the vicinity of the site on the north side of the river.

As the industrial park on the north continues to expand there will be increased pressure to use the site for industrial purposes. The area is well located for industry because of its access to the railroad and major highways.

In addition, there will be pressure to develop the southern section of the site as part of the colorado River parkway, a greenbelt area for recreation, preservation, and restoration. A citizens' group called Greenbelt, Inc., has as its goal the protection of suitable open and recreational space throughout the Grand Valley, including the banks of the colorado and Gunnison Rivers, for the public in perpetuity. The parkway project includes a park that is planned for a location along the Colorado River approximately $0.25 \mathrm{mi}$ west of the tailings pile.

The tailings pile is within the colorado River flood plain, and any new developnents at or near the site must conform to strict building codes. However, the tailings pile is located on gravel which, if not contaminated, is a resource that Grand Junction and Mesa county could put to use once the tailings are removed.

The largest of the old mill buildings and the quonset hut are presently being used for commercial activity. Each building is the place of full-time employment for two persons.

\subsection{IMPACT OF THE TAILINGS ON LAND VALUES}

Figure 4-4 summarizes the 1976 "listed values" of land ( $30 \%$ of assessed value) in Grand Junction. Land surrounding the tailings site has a market value ranging from $\$ 2,000$ to $\$ 13,000 /$ acre.

Most of the land in the area is privately owned (a considerable amount in the immediate vicinity belongs to colorado West Improvement, Inc.). The state of Colorado owns 40 acres of land immediately east of the tailings and a small plot alony the railroad. Mesa county owns a small plot in the residential-industrial area to the northwest. Two parcels of land to the south are owned by the school district. 
The 61.13 acres owned by the Sand Extraction Company, upon which the tailings are located, had an estimated 1977 market value of $\$ 33 /$ acre. The 6.55 acres owned by BESS Investments, on which the mill buildings are located, had an estimated market value of $\$ 1,600 /$ acre. The 1978 market value of the improvements on the property was estimated to be $\$ 37,400$.

The Grand Junction Steel Fabrication Company owns 1.3 acres of land in the industrial park north of the site. The unimproved market value of this land was estimated to be $\$ 10,400$ in 1977. This figure is typical of the land values in the industrial park area. Residential land northwest of the tailings had estimated market values of approximately $\$ 4,000 /$ half-acre lot in 1977. A feed pen which occupies 3.2 acres on the west side of the tailings has an estimated 1980 market value of $\$ 4.480$. Agricultural land is valued between $\$ 50$ and $\$ 1,000 /$ acre.

The presence of the tailings greatly restricts the use of the site as part of the industrial park on the north and as part of the proposed parkway along the river. The market value of the land would greatly increase if the tailings were not present.

At the present time industrial structures may be constructed in the immediate vicinity of the tailings pile. However, the Colorado Department of Health has issued a warning to prospective builders in the area bounded by winters Avenue on the north, 5th street on the west, the river on the south, and the site on the east. The warning states that elevated levels of radon from the pile may occur and corrective action may be necessary at a later date. Industrial development adjacent to the site has been slow. Land values north of the site increase with distance from the site. The determining factor in this increase in value is probably the proximity to the railroad rather than the presence of the tailings. 

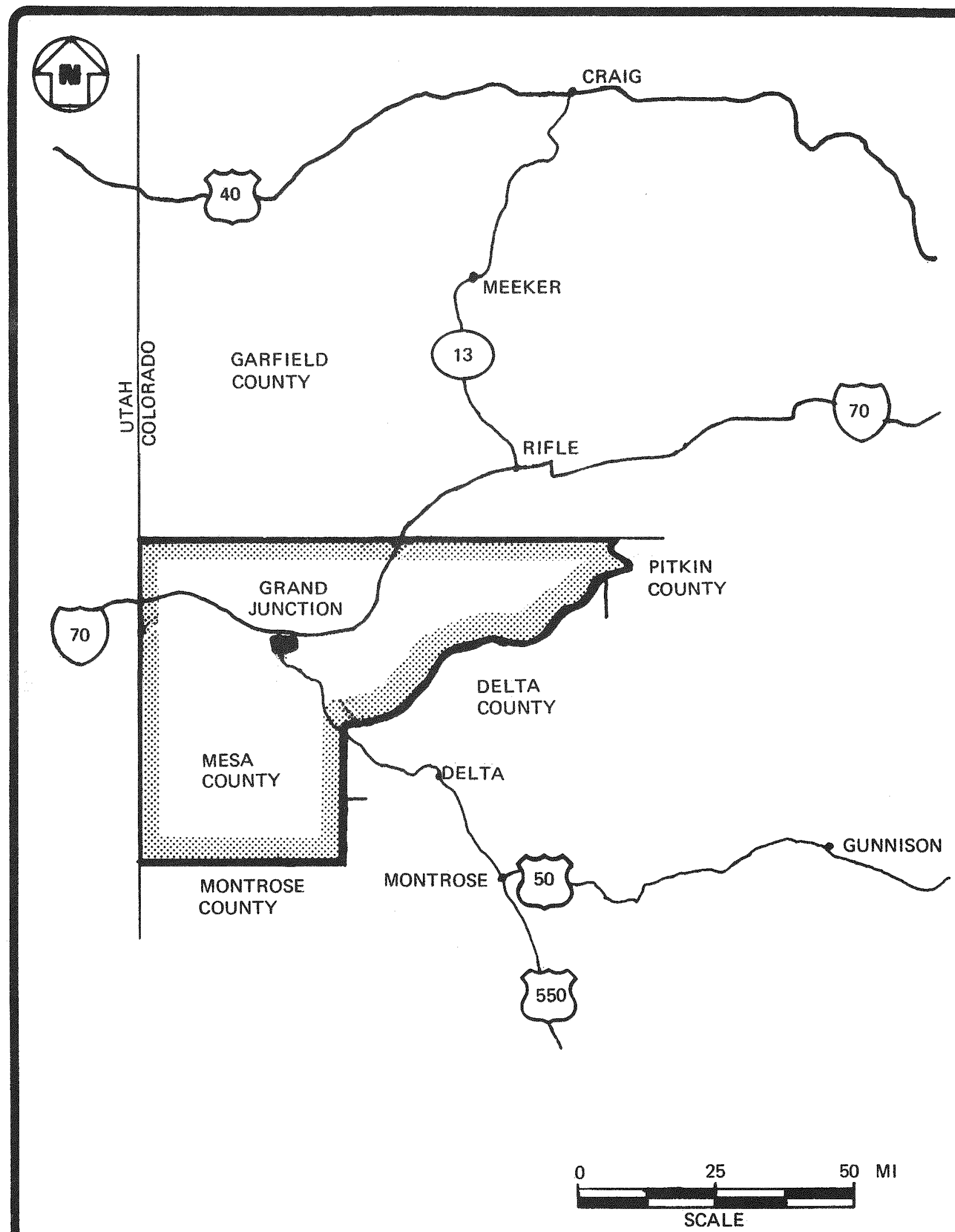

FIGURE 4-1. MAP OF MESA COUNTY BOUNDARIES 


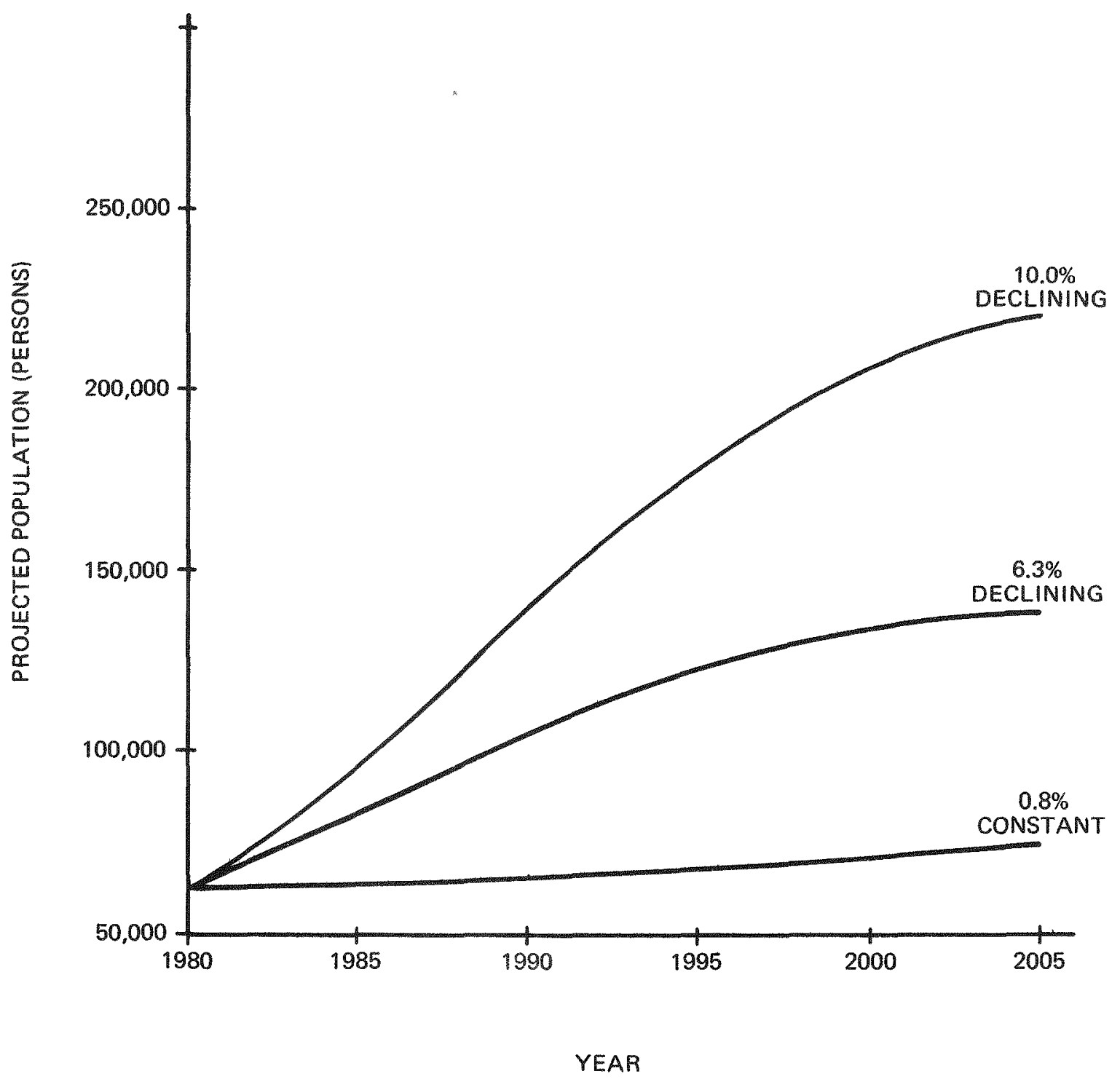

FIGURE 4-2. POPULATION PROJECTIONS 


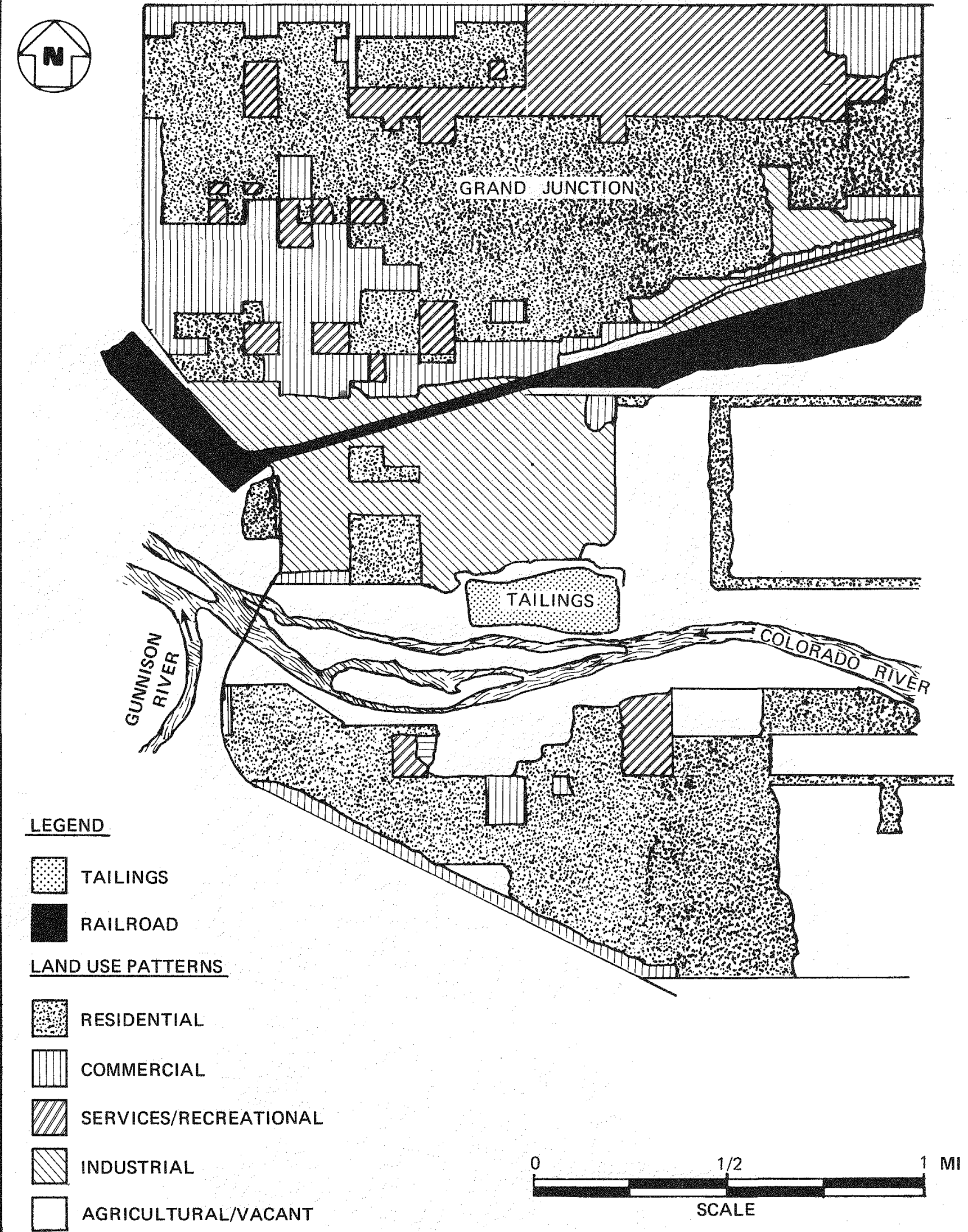

FIGURE 4-3. VICINITY LAND USE 
ford, Sacon \& Davis

4
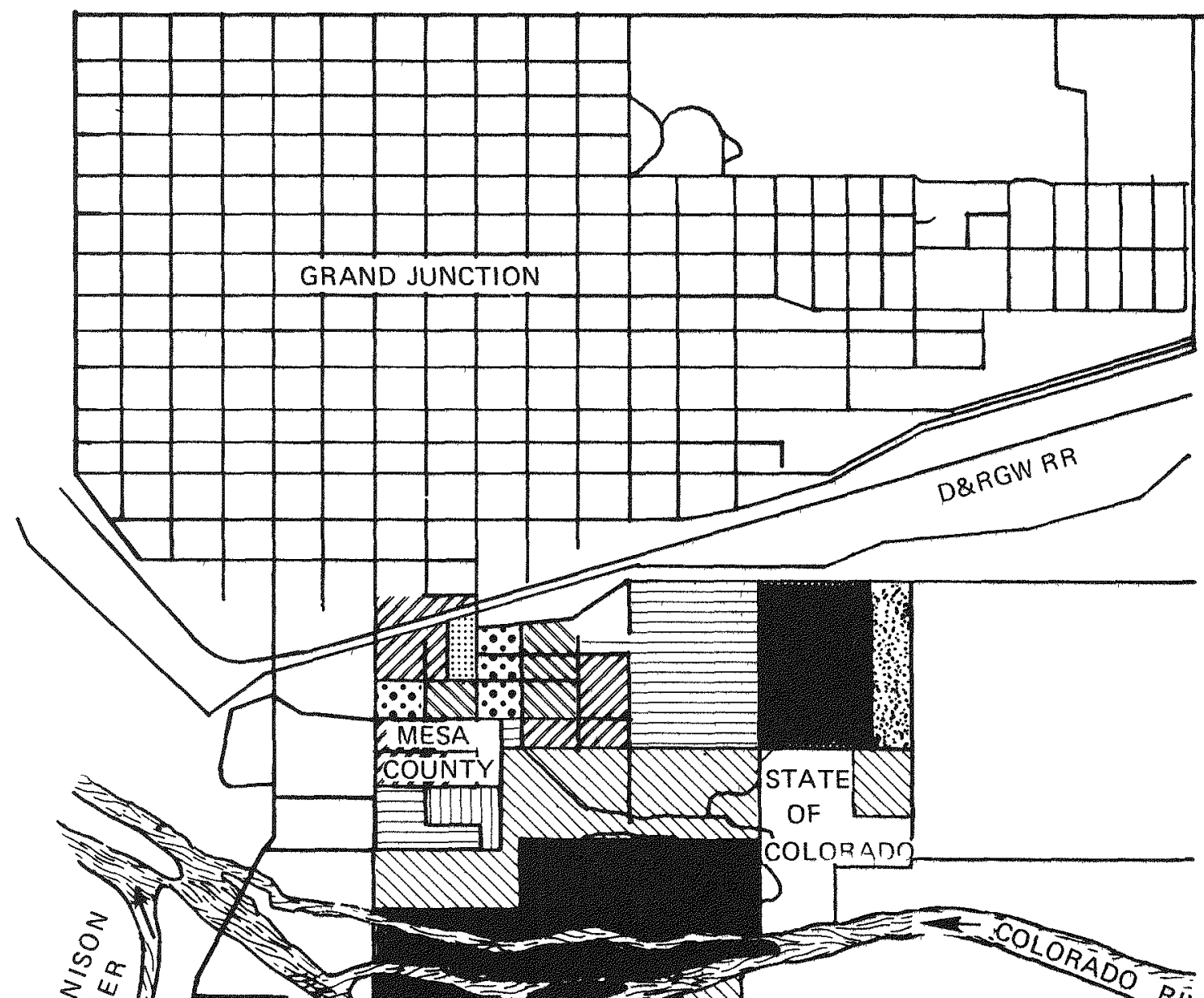

$\sum \psi$

$\sum_{0} \geqslant$
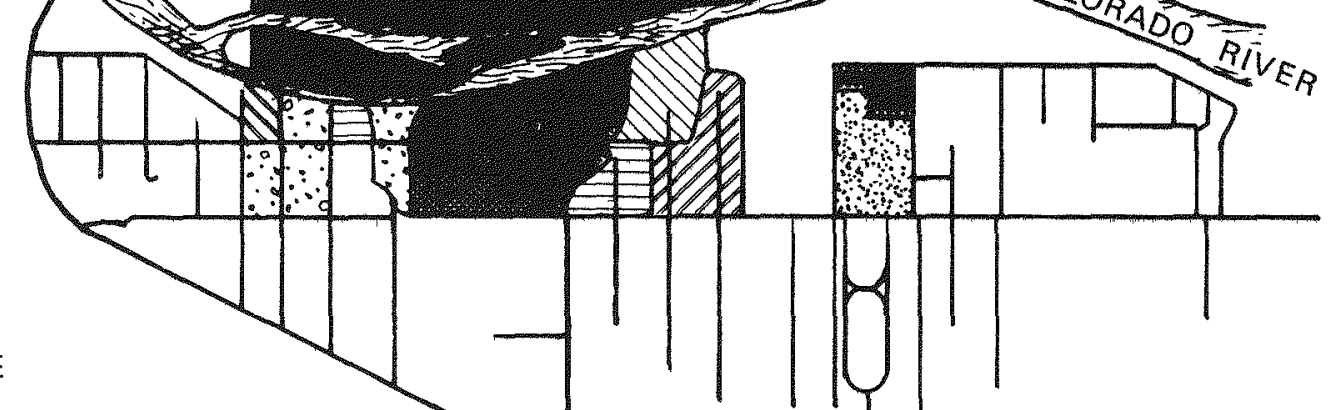

$\$ 101-1000 / \mathrm{ACRE}$

3 \$1001-2000/ACRE

\$2001-3000/ACRE

$\$ 3001-4000 / A C R E$

$\$ 4001-5000 / A C R E$

$\$ 5001-6000 / A C R E$

$\therefore \$ 6001-7000 / A C R E$

$\therefore \quad \$ 7001-8000 / A C R E$

18001 AND MORE

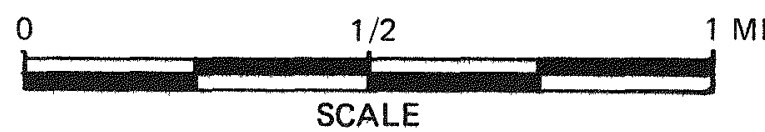

FIGURE 4-4. ASSESSED VALUE. OF LAND (30\% LEVEL) 
TABLE $4-1$

ESTIMATED 1980 POPULATION DISTRIBUTION

\begin{tabular}{|c|c|c|c|c|c|c|c|c|c|c|c|c|c|c|c|c|}
\hline & & & & & & & & Radius & (mi) & & & & & & & \\
\hline Direction & 0.1 & $\underline{0.2}$ & 0.3 & $\underline{0.4}$ & 0.5 & 0.75 & 1.0 & 1.5 & 2.0 & 2.5 & 3.0 & 3.5 & 4.0 & 5.0 & 6.0 & Total \\
\hline $\mathbb{N}$ & 1 & 1 & 0 & 0 & 0 & 559 & 717 & 929 & 2,210 & 1,402 & 1,044 & 1,044 & 1,304 & 500 & 0 & 9.711 \\
\hline $\mathrm{NNE}$ & 7 & 0 & 0 & 0 & 13 & 50 & 400 & 1,200 & 2,267 & 1.511 & 0 & 0 & 0 & 0 & 0 & 5,448 \\
\hline $\mathrm{NE}$ & 0 & 0 & 0 & 0 & 48 & 90 & 27 & 200 & 400 & 1.911 & 1,033 & 982 & 1.309 & 2,809 & 279 & 9,088 \\
\hline$E N E$ & 0 & 0 & 0 & 22 & 7 & 0 & 80 & 101 & 48 & 180 & 375 & 1,380 & 1.120 & 1.027 & 4,435 & 8,775 \\
\hline$E$ & 0 & 0 & 0 & 4 & 4 & 37 & 42 & 64 & 175 & 58 & 131 & 88 & 83 & 397 & 673 & 1.756 \\
\hline ESE & 0 & 0 & 0 & 4 & 18 & 60 & 420 & 301 & 683 & 280 & 127 & 195 & 110 & 302 & 116 & 2,616 \\
\hline$S E$ & 0 & 22 & 29 & 36 & 112 & 403 & 212 & 30 & 806 & 657 & 153 & 170 & 54 & 0 & 0 & 2,684 \\
\hline SSE & 0 & 21 & 49 & 94 & 84 & 192 & 89 & 153 & 161 & 0 & 0 & 0 & 0 & 0 & 0 & 843 \\
\hline $\mathrm{S}$ & 0 & 0 & 34 & 30 & 41 & 290 & 216 & 38 & 0 & 0 & 0 & 0 & 0 & 0 & 0 & 649 \\
\hline SSW & 0 & 0 & 15 & 80 & 46 & 36 & 0 & 0 & 0 & 0 & 0 & 0 & 0 & 0 & 0 & 177 \\
\hline SW & 0 & 0 & 110 & 90 & 127 & 66 & 0 & 0 & 0 & 65 & 35 & 0 & 0 & 0 & 0 & 493 \\
\hline WSW & 0 & 0 & 0 & 17 & 187 & 186 & 21 & 47 & 55 & 30 & 35 & 15 & 0 & 0 & 0 & 593 \\
\hline$W$ & 0 & 4 & 6 & 14 & 12 & 4 & 20 & 290 & 295 & 196 & 0 & 0 & 0 & 147 & 153 & 1,141 \\
\hline WNW & 0 & 52 & 128 & 49 & 13 & 60 & 14 & 403 & 545 & 282 & 575 & 783 & 655 & 1.793 & 2,827 & 8,179 \\
\hline NW & 1 & 3 & 22 & 60 & 0 & 65 & 160 & 598 & 144 & 382 & 263 & 113 & 124 & 138 & 355 & 2,428 \\
\hline NNW & 0 & 1 & 29 & 7 & 20 & 342 & 406 & 1.369 & 2,091 & 1,380 & 695 & 522 & 522 & 580 & 125 & 8,089 \\
\hline Tota 1 & 9 & 104 & 422 & 507 & 732 & 2,440 & 2,824 & 5,723 & 9,880 & 8,334 & 4,466 & 5,292 & 5,281 & 7,693 & 8,963 & 62,670 \\
\hline
\end{tabular}




\section{CHAPTER 4 REFERENCES}

1. Grand Junction Daily Sentinel; Aug 15, 1976.

2. Preliminary 1980 Census; Mesa County, Colorado; June 28, 1980 .

3. Colorado West Area Council of Governments, Impact Monitoring Program: Historic Information, Estimates of Existing Population Projections of Future Population: Jan 1980. 


\section{CHAPTER 5}

RECOVERY OF RESIDUAL VALUES 


\title{
CHAPTER 5
}

\author{
RECOVERY OF RESIDUAL VALUES
}

Samples of the tailings from the Grand Junction site were analyzed to determine the residual concentrations of valuable minerals. Table 5-1 shows the assay results on composite samples of the uranium and vanadium tailings. The uranium sample contained $0.018 \% \mathrm{U}_{3} \mathrm{O}_{8}$ and $0.176 \% \mathrm{~V}_{2} \mathrm{O}_{5}$. This compares favorably with the estimate of $0.017 \% \mathrm{U}_{3} \mathrm{O}_{8}$ based on AEC records of the plant operation. No other metals are present in significant concentrations.

No tests to determine uranium extractability (amenability) were performed on the samples of Grand Junction tailings. In the absence of testing, the estimates of uranium recovery in reprocessing operations are based on data provided by DOE's Grand Junction office, as shown in Figure 5-1. Based on an estimated grade of $0.017 \% \mathrm{U}_{3} \mathrm{O}_{8}$, it is expected that the recovery of uranium by a conventional process will be about 408 , or $0.14 / 1 \mathrm{~b} \mathrm{U}_{3} \mathrm{O}_{8} /$ ton of tailings. By heap leaching, recovery would be about 23\%, or 0.081 b U $\mathrm{U}_{3} / \mathrm{ton}$. At current prices (September 1980 ) of $\$ 28.50 / \mathrm{Ib}$ of $\mathrm{U}_{3} \mathrm{O}_{8}$, the total income from uranium recovery would be approximately $\$ 2.25$ to $\$ 4.00 /$ ton. The vanadium in the Grand Junction tailings, based on a sales price for $\mathrm{V}_{2} \mathrm{O}_{5}$ of $\$ 3 / 1 \mathrm{~b}$, and assuming recovery rates similar to that for uranium, would produce income of about the same level; i.e., $\$ 2$ to $\$ 4 /$ ton treated.

\subsection{PROCESS ALTERNATIVES}

There are three principal alternatives for the reprocessing of the Grand Junction tailings. They are as follows:

(a) Heap leaching

(b) Treatment at an existing mill

(c) Reprocessing at a new conventional mill constructed for tailings reprocessing

\section{1 .1 Heap Leaching}

There are two process variations in use for heap leaching. In the first method, which has been used successfully to treat low grade ore which otherwise would not warrant treatment, a pad is prepared with an impermeable layer at the bottom. A pipe drainage system is laid down and covered with gravel and sand. The tailings are deposited on this base in a layer up to about 20-ft-thick, the surface being contoured in shallow basins to contain the leach solution. An acid solution, sometimes with added oxidant, is allowed to flow into the surface basins and to 
percolate through the bed. The solution collected is treated, usually by ion exchange or solvent extraction, to recover the uranium. When present, vanadium can be recovered in a second solvent extraction circuit. The recovery that can be achieved with this method is highly dependent upon the porosity, the uniformity of the ore on the pad, and the extent of channeling. Because of these factors, recovery of values is considerably lower than by conventional plant processes. roughly half, as shown in Figure 5-1.

In the second method, the ore, crushed to minus $3 / 4-i n$. size, is premixed with a strong sulfuric acid solution and pelletized before being placed for leaching. Water is percolated through the bed, the recovered solution being processed to recover the solubilized uranium and vanadium. Where vanadium is to be recovered, a higher concentration of acid is required than if the tailings are being processed only for uranium. The pelletizing procedure involves increased handling and higher plant cost, but is likely to result in improved recovery of values over the heap-leach method described above due to better contact of the ore with the acid and improved uniformity of porosity.

A large proportion of the ore treated in the Grand Junction plant had a high clay content. The plant employed a sand-slime separation process. The sands were leached in vats. The slimes were treated by a salt roast, acid leach process to recover vanadium and uranium. plant records indicated that sand and slime tailings were impounded separately; however, in remedial action efforts to date, the sands and slimes have been observed to be greatly intermixed. Any reprocessing will be complicated by the fact that the sand portion, which comprised $70 \%$ of the ore, contained only $30 \%$ of the values. The slime tailings, which contain most of the values, will be difficult to treat by heap leaching. Careful blending is needed to produce permeable heap leach piles. However, because of the way in which the pile was recontoured at the close of operations, sand and slime may not always be accessible in the required ratio. The feasibility of the pelletizing procedure is questionable and depends on whether or not the pelletized tailings retain their shape or disintegrate when flooded by leachate. Recovery of values is unlikely to exceed two-thirds of that of a conventional plant.

The predicted maximum recovery of uranium from the Grand Junction tailings by heap leaching is in the range of 0.08 to $0.10 \mathrm{lb} / \mathrm{ton}$ of $\mathrm{U}_{3} \mathrm{O}_{8}$ treated, out of the average $0.34 \mathrm{lb} / \mathrm{ton}$ present. This represents a maximum revenue of $\$ 2.60$ to $\$ 3.25 /$ ton. Vanadium recovery is estimated to be in the range of 0.8 to $1.01 \mathrm{~b} /$ ton, valued at $\$ 2.40$ to $\$ 3.00$. In the absence of amenability tests on representative samples, these estimates must be considered as qualitative only, and not as a reliable basis for planning commitments. 


\subsubsection{Treating in an Existing plant}

For reprocessing in an existing conventional plant to be feasible, a mill with significant excess capacity must be located reasonably close to the present tailings site. The mill also must have a tailings disposal site with sufficient capacity to handle the additional tailings and allow for adequate long-term stabilization. In addition to the tailings, there are about $1.3 \mathrm{million}$ tons of contaminated waste at the Grand Junction site. (1) Further contaminated soils will be generated as the cleanup of locations in Mesa county continues. removing tailings used for construction and other purposes.

To remove the 1,900,000 tons of tailings from the Grand Junction site within 3 yr represents a rate of 1,800 tons/day, 350 days/yr. Operating at the same rate, removal of 1,300,000 tons of contaminated soils would require an additional 2 yx. No existing mill could devote such capacity to this low-grade material on a current basis. stockpiling for treatment over an extended period, even though it involves double handing, would be required.

5.1 .3 Treating in a New MiII

Construction of a new mill to reprocess the tailings would permit: (a) plant design tailored for the material to be processed, (b) siting suitable for long-term tailings stabilization, and (c) optimum plant capacity and uranium recovery. The major disadvantage is in the high cost of new plant construction. The quantity of uranium tailings on the Grand Junction site, 1,900,000 dry tons, would feed a 2.000 ton/day plant for about $3 \mathrm{yr}$. Normally, amortization of a plant is based on planned operation for 10 to 12 yr.

\subsection{GRAND JUNCTION RECOVERY ECONOMICS}

The parameters discussed in this section determine the economic viability of reprocessing uranium mill tailings to recover residual mineral values.

5.2.1 Market for Uranium

The demand and price for uranium from 1976 to 1980 have gone through a rapid rise-and-fall cycle. Spot prices for uranium as indicated by the exchange values reported by NUEXCO rose from $\$ 30 / 1 \mathrm{~b}$ of $\mathrm{U}_{3} \mathrm{O}_{8}$ in November 1975 to $\$ 43 / 1 \mathrm{~b}$ in Novermber 1977 and essentially held constant until the end of 1979. The price dropped precipitously to $\$ 28.50 / 1 \mathrm{~b}$ of $\mathrm{U}_{3} \mathrm{O}_{8}$ by september 1980 and $\$ 25 / 1 b$ early in 1981 .

A variety of factors has contributed to this pattern. including the Three Mile Island accident and the subsequent delays in nuclear plant licensing, rapidly escalating power 
plant costs, and the inflexibility of uranium production operations. Total uranium inventories held by U.S. companies as of January 1, 1979 were 44,700 tons equivalent $\mathrm{U}_{3} \mathrm{O}_{8}$, representing nearly 3 times the current annual consumption rate. projected domestic uranium supply exceeds apparent buyer requirements each year through 1984.(2) under these circumstances no basis is evident for a turnaround in uranium prices for about 5 yr. (3) The supply and market for uranium as estimated by the DOE Assistant Secretary for Resource Applications are given in Table 5-2.

\subsubsection{Escalation of Plant Construction cost}

The estimated construction costs of both heap leach plants and conventional mills without crushing and grinding facilities, as provided by the DOE Grand Junction, Colorado office, were included as figures in the Phase II, Title I Engineering Assessment report.(4) The costs were adjusted to January 1977. Since then, relatively few plants have been built, and reported costs have been strongly influenced by new tailings control and stabilization requirements under NRC licenses. Recent estimates by $R \cdot B$. Coleman of construction costs for conventional plants have been in the range of $\$ 13,000$ to $\$ 30,000 /$ ton of daily plant capacity. (5) In view of the many significant site-specific problems that can influence capital costs, for this report it was decided to apply suitable escalation factors to the 1977 Grand Junction office estimates, which are based on construction costs of many plants.

The Engineering News Record(6) publishes quarterly reports on various construction cost indexes. The following data are derived from this source:

\begin{tabular}{|c|c|c|c|c|}
\hline & $\begin{array}{l}\text { Avg } \\
\text { Index } \\
1977 \\
\end{array}$ & $\begin{array}{l}\frac{\text { Latest }}{\text { Date }} \\
\text { (1980) }\end{array}$ & $\begin{array}{c}\text { Reported } \\
\text { Index }\end{array}$ & $\begin{array}{l}\text { Percent } \\
\text { Increase }\end{array}$ \\
\hline Nelson Refinery Cost Index & 223 & $\operatorname{Jan}$ & 276 & 23.8 \\
\hline $\begin{array}{l}\text { Chemical Engineering Plant } \\
\text { Cost }\end{array}$ & 186 & Apr & 234 & $25 \cdot 4$ \\
\hline $\begin{array}{l}\text { Engineering Construction } \\
\text { cost ( } 20 \text { Cities) }\end{array}$ & 240 & Jun & 298 & $24 \cdot 2$ \\
\hline
\end{tabular}

The Producer Price Index of Industrial Commodities(3) has increased as follows in the 1977-1980 period: 
Annual

Total

Period

Annual Average 1977

Annual Average 1978

Annual Average 1979

June 1980

\section{Index}

195.1

209.4

236.5

273.0
Increase

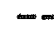

$7 \cdot 3$

$21 \cdot 2$

$39 \cdot 9$
$7 \cdot 3$

12.9

Percent

Increase

15.4

From the above indexes, an increase in plant construction cost of $25 \%$ from January 1977 to mid-1980 has been applied as a conservative estimate. As indicated in Figure 5-2, the capital cost of a 2,000 ton/day heap-leach facility would be about $\$ 12.5$ million. As indicated in Figure 5-3, the cost for a conventional mill of similar capacity would be about $\$ 16$ million. If these capital costs were to be amortized on the Grand Junction tailings only, the unit costs would be $\$ 6.60$ to $\$ 8.40 /$ ton, or from $\$ 82.50$ to $\$ 114 / 1$ b of $\mathrm{U}_{3} \mathrm{O}_{8}$ recovered. Additional capital costs will be incurred if a vanadium recovery circuit is included.

\subsubsection{Escalation of plant Operating Cost}

The operating costs of uranium mills appear to have risen much more steeply than construction costs. In the Phase II, Title I engineering assessments, the direct operating costs of a 2,000 ton/day facility were estimated at $\$ 3.10$ and $\$ 4.50 /$ ton for heap-leach and conventional acid-leach mills, respectively. However, R.B. Coleman(5) reports that 1980 operating costs of conventional mills are in the range of $\$ 8.70$ to $\$ 18.40 /$ ton.

Ranchers Exploration and Development Corporation reported their operating costs for heap leaching at Naturita, approximately a 1,200 ton/day facility, at about $\$ 34 / 1$ b of $U_{3} O_{8}$ recovered, equivalent to $\$ 20.50 /$ ton of tailings processed. costs of vanadium recovery were reported separately. In Figure 5-4, Grand Junction DOE 1977 estimates for heap-leach are compared with Ranchers' 1978-1979 experience at Naturita. In Figure 5-5, conventional acid-leach plant operating costs are compared with 1980 data reported by coleman. The data indicate that conventional milling costs have risen by $250 \%$, and the heap leaching cost is higher by 400 to $500 \%$. However, the slope of the heap-leach line is not confirmed by later information. Consequently, the dotted 1 ine in Figure 5-4 is considered more representative and has been used as a basis of estimates.

considering the differences in plant designs, it is estimated that average mill operating costs have increased by a factor of 2.5 from the January 1977 costs to mid-1980. This would result in operating costs for Grand Junction tailings 
in a 2,000 ton/day conventional plant of about $\$ 11.50 /$ ton, or $\$ 82 / 1 \mathrm{~b} \mathrm{U}_{3} \mathrm{O}_{8}$ recovered (assuming $0.14 \mathrm{lb}$ recovered/ton). For a heap-leach plant of this same size, the corresponding figures would be $\$ 9.25 /$ ton and $\$ 116 / 1$ b recovered. A comparison of capital and operating costs for various plant sizes is given in Table 5-3.

\subsubsection{Competitive Market Factors}

The average grade ore processed in conventional mills has decreased from $0.15 \% \mathrm{U}_{3} \mathrm{O}_{8}$ in 1977 to $0.11 \%$ in 1979. The average recovery rate for the industry has been $91 \pm 1 \%$ during this period. (7) However, since tailings have been processed previously, the recoveries in reprocessing are likely to be much lower as reflected in Figure 5-1. To produce a given quantity of uranium, roughly 10 times as much Grand Junction tailings material must be processed as when a mill is operating on ore of the average grade treated in 1979. Thus, the volume of tailings to be stabilized is also 10 times greater. In a competitive market, the Grand Junction tailings are at a substantial disadvantage.

\subsection{CONCLUSION}

Based on the foregoing analysis, it is concluded that the processing of Grand Junction tailings for the recovery of additional uranium in connection with the tailings stabilization operations, either by heap-leach or conventional plant processes, is likely to be economically unattractive at the present time and is likely to remain so for the foreseeable future. For processing this material, the optimum plant size is roughIy 2,000 to 2,500 tons/day, and the cost of the uranium recovered would be about $\$ 200 / 1 \mathrm{~b} \mathrm{U}_{3} \mathrm{O}_{8}$ by heap-leach and $\$ 150 / 1 \mathrm{~b}$ by conventional plant processes. The cost is, of course, very sensitive to the percent recovery of metal values, which can be only roughly estimated in the absence of amenability tests on representative samples. Capital costs might be lowered if another source of feedstock could be provided for the plant. However, operating costs, exclusive of any capital, appear to be well in excess of the market value of uranium. Byproduct vanadium recovery is marginal, and will not materially alter these conclusions.

The spot market price for uranium in september 1980, when the economic analyses in this chapter were prepared, was $\$ 28.50 / 1 \mathrm{~b}$ of $\mathrm{U}_{3} \mathrm{O}_{8}$. Since that time, construction costs have continued to rise, while the spot market price for uranium has declined to about $\$ 25 / 1$ b of $U_{3} O_{8}$ early in 1981 . These trends further reduce the economic attractiveness of tailings reprocessing. 


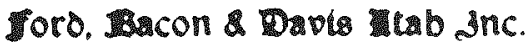

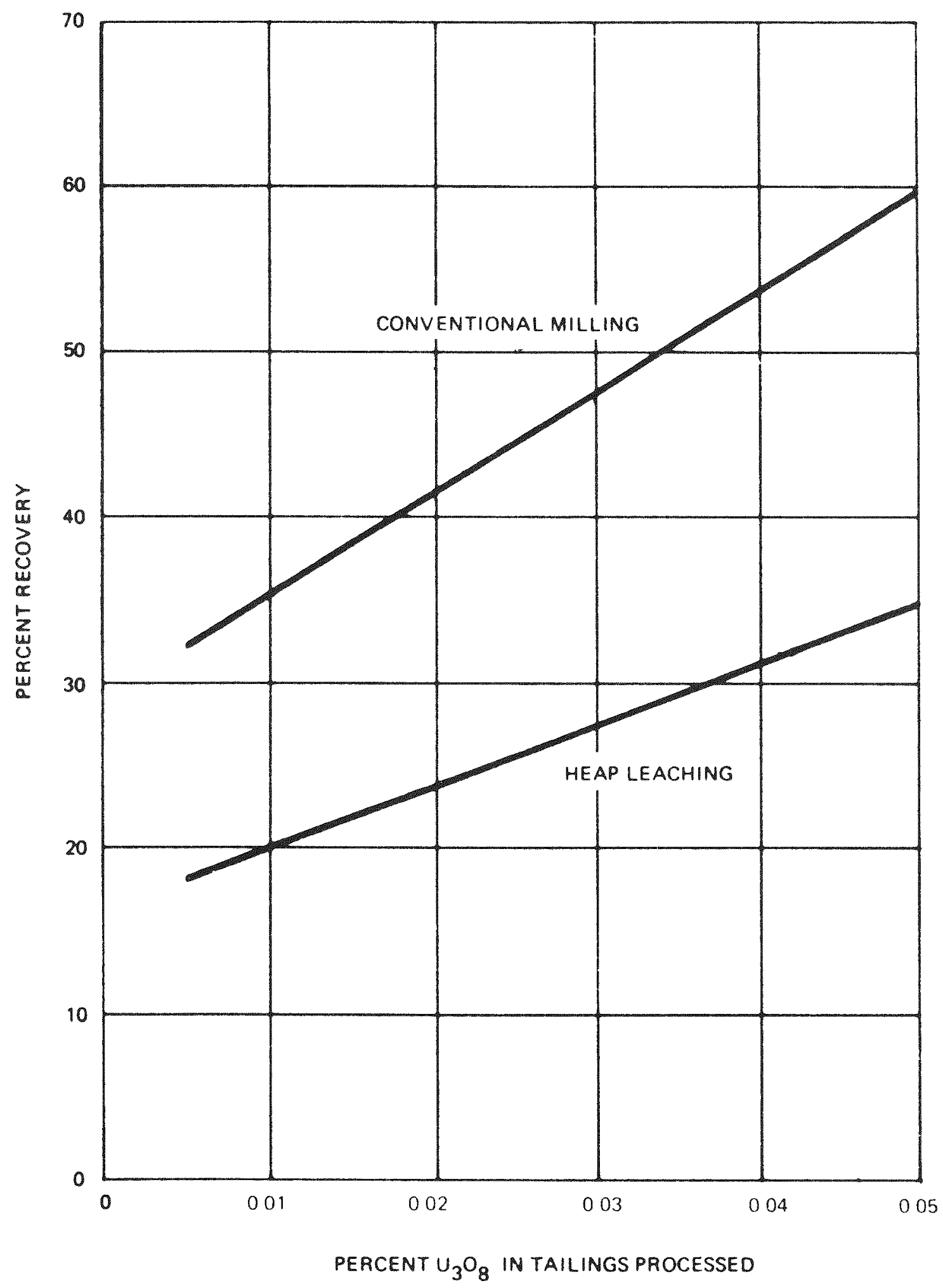

FIGURE 5-1. URANIUM RECOVERY FROM MILL TAILINGS AS A FUNCTION OF $U_{3} O_{8}$ CONTENT IN TAILINGS 
ford, Sacon \& Davis

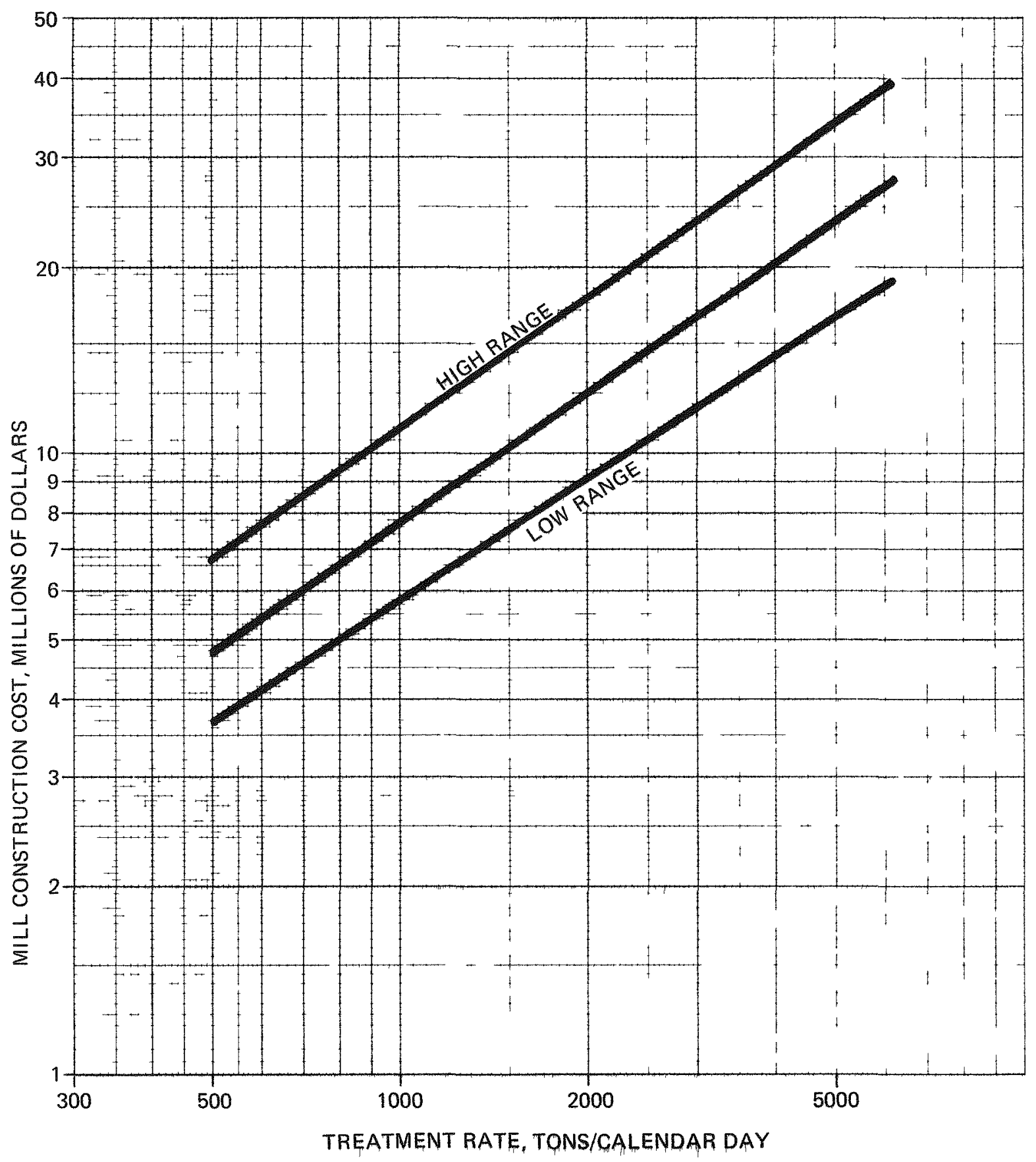

FIGURE 5-2. CONSTRUCTION COSTS OF HEAP LEACHING PLANT TO REPROCESS URANIUM MILL TAILINGS (COST ADJUSTED TO JULY 1980) 


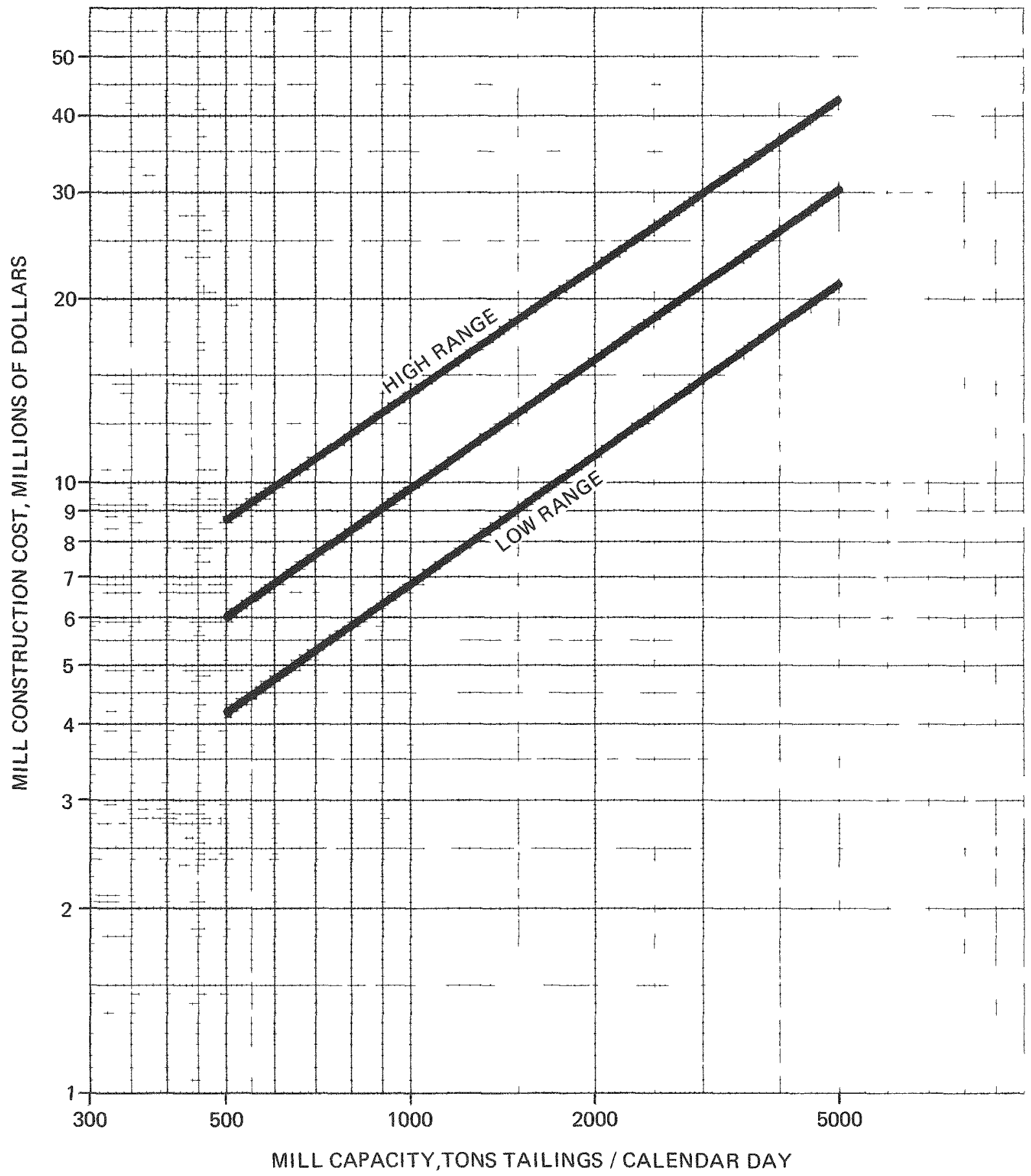

FIGURE 5-3. CONSTRUCTION COSTS OF A CONVENTIONAL URANIUM MILL TO REPROCESS TAILINGS W/O CRUSHING AND GRINDING FACILITIES OR TAILINGS STABILIZATION COSTS (COST ADJUSTED TO JULY 1980) 


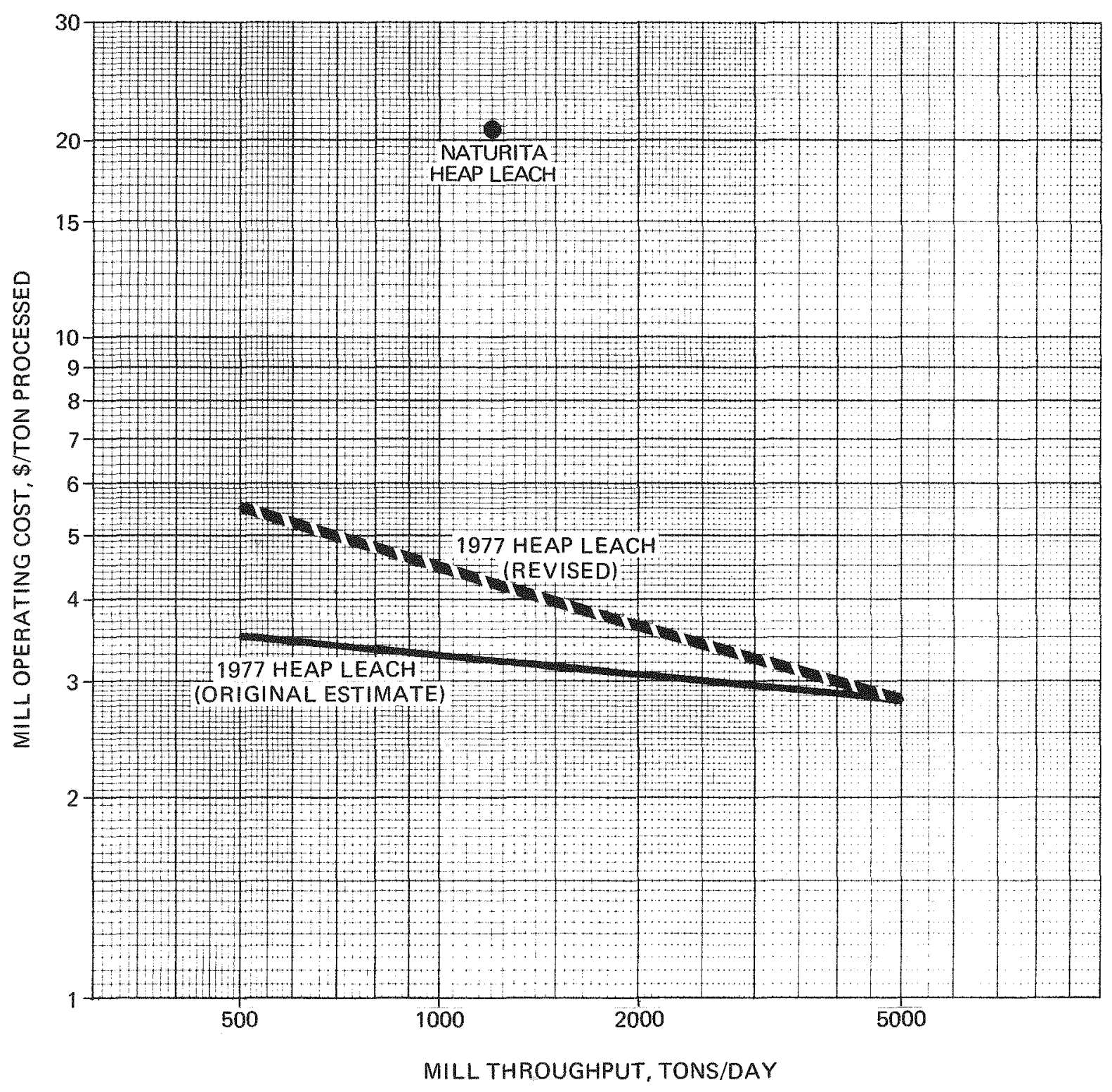

\section{FIGURE 5-4. OPERATING COSTS OF HEAP LEACHING OF URANIUM MILL TAILINGS}




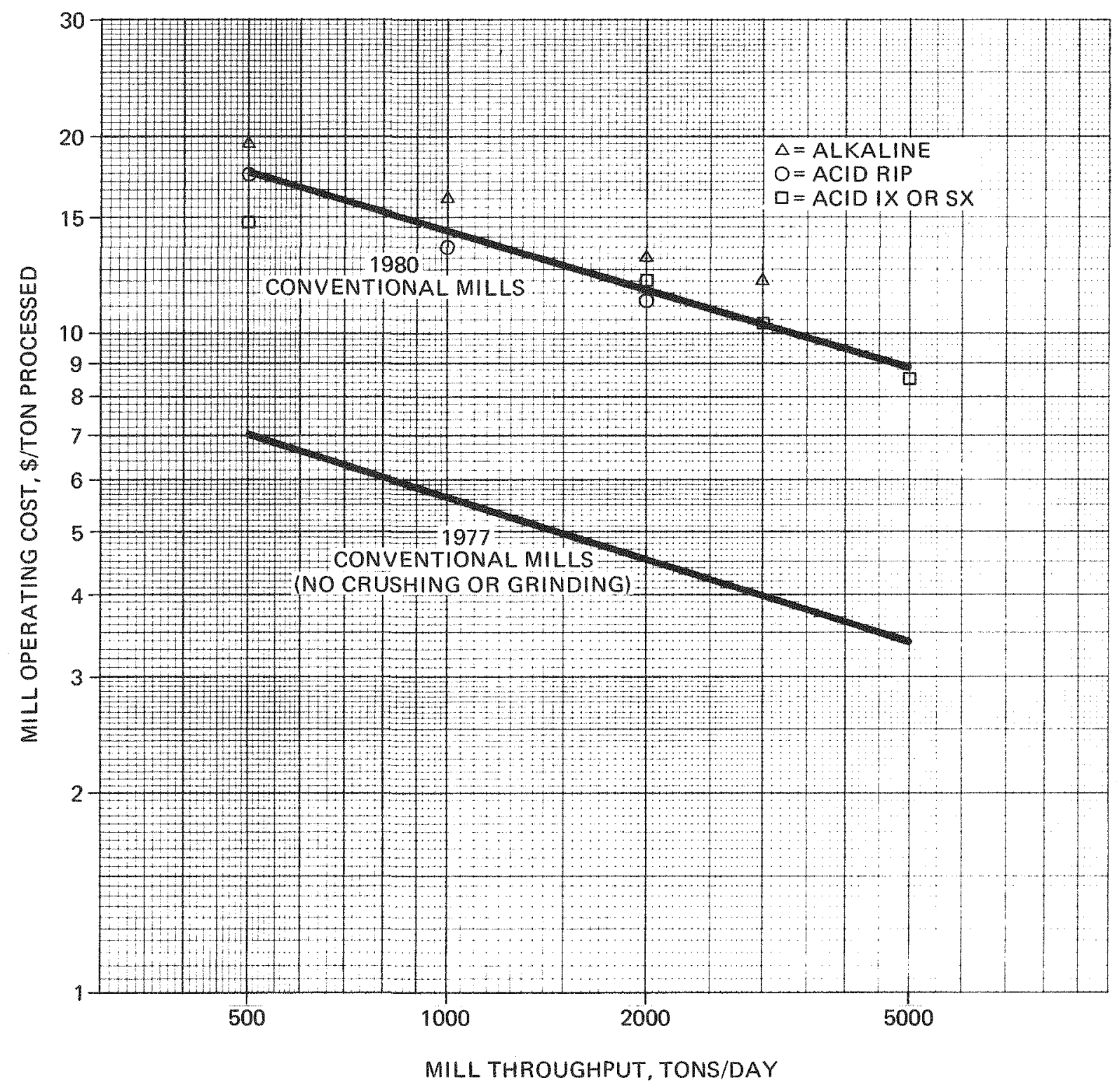

FIGURE 5-5. OPERATING COSTS OF CONVENTIONAL MILLING W/O CRUSHING AND GRINDING FACILITIES TO REPROCESS TAILINGS (COST ADJUSTED TO JULY 1980) 
TABLE 5-1

ASSAY RESULTS OF COMPOSITE TAILINGS AND BACKGROUND SAMPLES

\begin{tabular}{|c|c|c|c|c|c|}
\hline \multicolumn{6}{|c|}{ Percentage by Weight } \\
\hline Element & $\begin{array}{c}\text { Atomic } \\
\text { Alosorption }\end{array}$ & Spectrographic & Chemical & $\begin{array}{c}\mathrm{AEC}^{*} \\
\text { Estimate }\end{array}$ & $\begin{array}{l}\text { Background } \\
\text { Composite } \\
\end{array}$ \\
\hline Aluminum & -- & $>1.0$ & -- & - & -- \\
\hline Arsenic & 0.00141 & -- & -- & -- & 0.000165 \\
\hline Barium & 0.0121 & -- & -- & -- & -- \\
\hline Boron & -- & $<0.01$ & -- & -- & $-\infty$ \\
\hline Cadmium & 0.00016 & -- & -- & -- & -- \\
\hline Calcium & -- & $>1.0$ & -- & -- & -- \\
\hline Chromium & 0.0029 & -- & -- & -- & -- \\
\hline Cobalt & 0.00251 & -- & -- & -- & $-\infty$ \\
\hline Copper & 0.00137 & -- & -- & $-\infty$ & -- \\
\hline Cyanide & $<0.000001$ & -- & -- & -- & $-\infty$ \\
\hline Ga11ium & -- & $<0.01$ & -- & -- & -- \\
\hline Iron & 0.117 & -- & -- & $-\infty$ & -- \\
\hline Lead & 0.00505 & -- & -- & -- & -- \\
\hline Magnesium & - & $>1.0$ & -- & -- & -- \\
\hline Manganese & -- & $0.1-0.01$ & -- & $-\infty$ & -- \\
\hline Mercury & 0.0000026 & -- & $-\infty$ & $-\infty$ & $-m$ \\
\hline Molybdenum & -- & $<0.01$ & -- & -- & $-\infty$ \\
\hline Nickel & $-\infty$ & $<0.01$ & -- & -- & -- \\
\hline Potassium & -- & $1.0-0.01$ & -- & $-\infty$ & -- \\
\hline Selenium & 0.000306 & -- & -- & -- & 0.0000443 \\
\hline Silica & -- & $>1.0$ & $-\infty$ & $-\infty$ & -- \\
\hline Silver & 0.000072 & -- & -- & $-\infty$ & -- \\
\hline sodium & -- & $>1.0$ & -- & -- & -- \\
\hline Titanium & -- & $1.0-0.01$ & -- & -- & -- \\
\hline Uranium $\left(\mathrm{U}_{3} \mathrm{O}_{8}\right)$ & -- & -- & 0.018 & 0.017 & -- \\
\hline Vanadium $\left(\mathrm{V}_{2} \mathrm{O}_{5}\right)$ & - & -- & 0.176 & -- & -- \\
\hline $\operatorname{Zinc}$ & 0.00448 & -- & $-\infty$ & -- & -- \\
\hline
\end{tabular}

* Calculated tailings assay based on plant operation(1) 
TABLE 5-2

U.S. URANIUM SUPPLY AND MARKET SUMMARY

\begin{tabular}{|c|c|c|c|c|c|c|c|c|}
\hline Year & $\begin{array}{c}\text { (1) } \\
\text { Sales Co } \\
\text { To } \\
\text { Domestic } \\
\text { Buyers } \\
\end{array}$ & $\begin{array}{c}(2) \\
\text { To } \\
\text { Foreign } \\
\text { Buyers } \\
\end{array}$ & $\begin{array}{l}\quad \text { (3) } \\
\text { Est. } \mathrm{U}_{3} \mathrm{O}_{8} \\
\text { To Be } \\
\text { Available } \\
\text { For Sale } \\
\end{array}$ & $\begin{array}{l}\text { (4) } \\
\text { Procure- } \\
\text { ment of } \\
\text { Foreign } \\
\text { Uranium }\end{array}$ & $\begin{array}{c}\text { (5) } \\
\\
\text { Reported } \\
\text { Unfilled } \\
\text { Requirement } \\
\end{array}$ & $\begin{array}{l}\quad(6) \\
\text { Total } \\
\text { Domestic } \\
\text { Production } \\
\text { Potential } \\
(1+2+3) \\
\end{array}$ & $\begin{array}{c}\text { (7) } \\
\text { Total } \\
\text { Dornestic } \\
\text { Supply } \\
(1+3+4) \\
\end{array}$ & $\begin{array}{c}\text { (8) } \\
\text { Apparent } \\
\text { Buyer } \\
\text { Requirements } \\
(1+4+5) \\
\end{array}$ \\
\hline $\begin{array}{l}1980 \\
1981 \\
1982 \\
1983 \\
1984 \\
1985 \\
1986 \\
1987 \\
1988 \\
1989 \\
1990\end{array}$ & $\begin{array}{r}21,500 \\
20,000 \\
19,400 \\
17,400 \\
16,000 \\
13,900 \\
11,200 \\
11,400 \\
10,500 \\
9,500 \\
7,300\end{array}$ & $\begin{array}{r}2,000 \\
1,000 \\
1,000 \\
900 \\
500 \\
500 \\
300 \\
300 \\
300 \\
100 \\
100\end{array}$ & $\begin{array}{l}2,600 \\
3,100 \\
4,300 \\
7,100 \\
7,800 \\
8,800\end{array}$ & $\begin{array}{l}1,800 \\
2,700 \\
2,800 \\
2,500 \\
2,500 \\
2,400 \\
1,000 \\
1,000 \\
1,000 \\
1,000 \\
1,000\end{array}$ & $\begin{array}{r}400 \\
800 \\
1,300 \\
1,800 \\
4,000 \\
4,300 \\
9,900 \\
11,700 \\
12,000 \\
15,100 \\
14,400\end{array}$ & $\begin{array}{l}26,100 \\
24,100 \\
24,700 \\
25,400 \\
24,300 \\
23,200\end{array}$ & $\begin{array}{l}25,900 \\
25,800 \\
26,500 \\
27,000 \\
26,300 \\
25,100\end{array}$ & $\begin{array}{l}23,700 \\
23,500 \\
23,500 \\
21,700 \\
22,500 \\
20,600 \\
22,100 \\
24,100 \\
23,500 \\
25,600 \\
22,700\end{array}$ \\
\hline
\end{tabular}

Source: DOE/RA-0053

Survey of United States Uranium Marketing Activity, July 1980 (p. 17) GJO-100 (80) 
TABLE 5-3

ESTIMATED URANIUM COSTS FROM GRAND JUNCTION TAILINGS

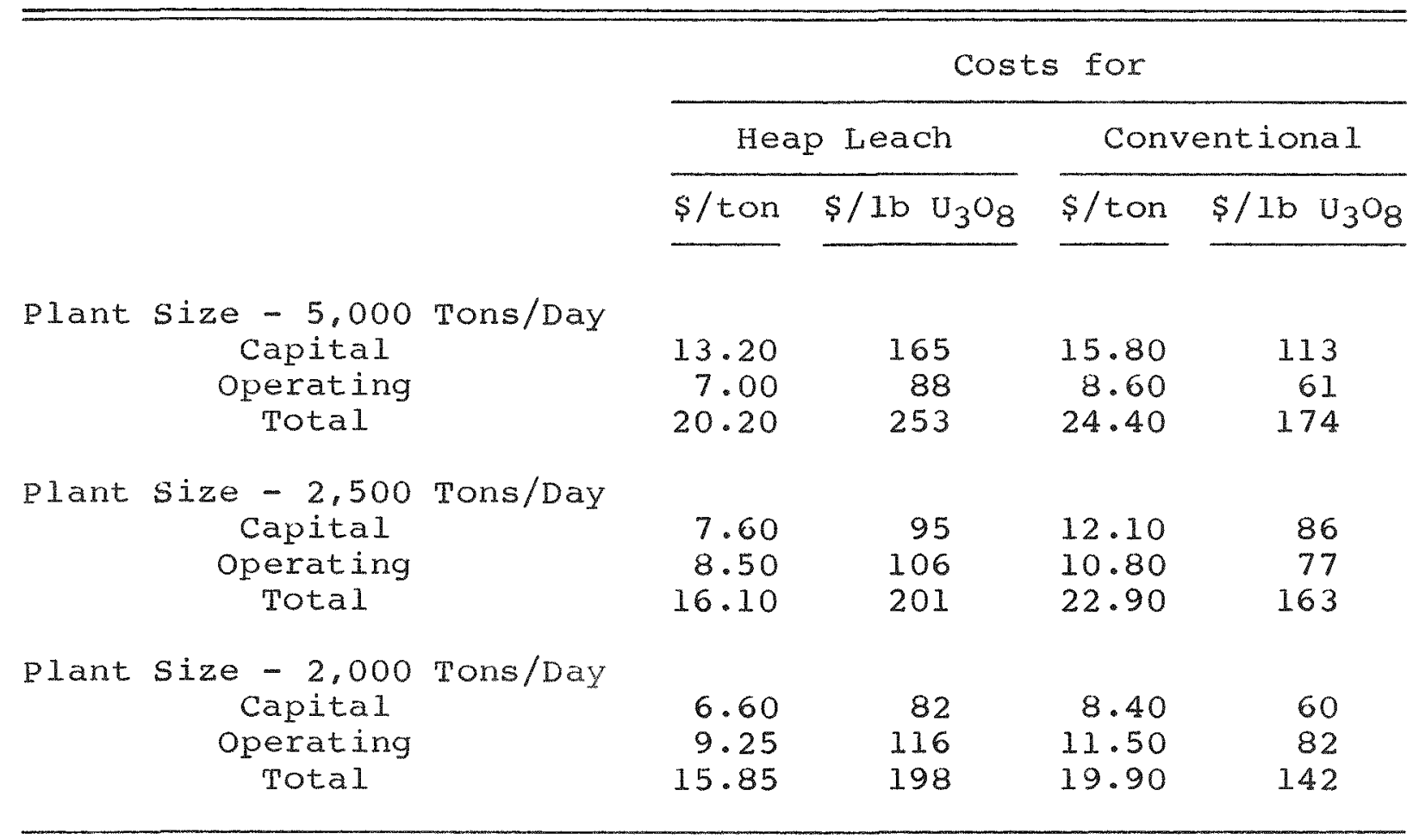

Assumptions: (a) $1,900,000$ dry tons tailings at $0.017 \% \mathrm{U}_{3} \mathrm{O}_{8}$

(b) Recovery by heap leach $0.08 \mathrm{lb} / \mathrm{ton}$, by conventional plant $0.14 \mathrm{lb} / \mathrm{ton}$

(c) No other source of plant feed

(d) No costs included for transportation, stabilization of tailings, or escalation beyond 1980 
1. "Phase II - Title I, Engineering Assessment of Inactive Uranium Mill Tailings, Grand Junction Site, Grand Junction, Colorado": by Ford, Bacon \& Davis Utah Inc.; Oct 1977.

2. Survey of United states Uranium Marketing Activity: DOE/RA-0053; U.S. Department of Energy; July 1980.

3. NUEXCO No. 144, p. 27; published by Nuclear Exchange Corporation, 3000 Sand Hill Road, Menlo Park, California 94025; Aug 1980 .

4. "Phase II - Title I, Engineering Assessment of Inactive Uranium Mill Tailings, Shiprock Site, Shiprock, New Mexico" (Figures 5-4/5-5); GJT-2; by Ford, Bacon \& Davis Utah Inc.; $\operatorname{Mar} 31,1977$.

5. Uranium Miling Costs by R.B. Coleman, Hazen Research, Inc., presented at Colorado school of Mines seminar: Mar 12, 1980.

6. Engineering News Record, Vol 204, No. 25, pp. 75 and 79; June 19, 1980.

7. Statistical Data of the Uranium Industry; GJo-100 (80); pp. 93 and 94 . 
CHAPTER 6

MILL TAILINGS STABILIZATION 


\section{MILL TAILINGS STABILIZATION}

In all alternate remedial actions considered in this study, the stabilization of mill tailings is required. Stabilization. as used here, means implementation of efforts to prevent the introduction of potentially harmful materials into the biosphere from the tailings. Government agencies and private industry have conducted and are conducting research to develop economical and environmentally suitable methods of stabilizing uranium mill tailings. The methods, technology, and data on stabilization that are presently available were reviewed and are described in this chapter. This information includes results from previous investigations, as well as findings of current and continuing research.

The objective of stabilizing the uranium mill tailings is to eliminate the pathways to the environment for the radioactive and other toxic particles which are described in chapter 3. Alternatively, conditioning tailings might significantly reduce the rate at which potentially hazardous substances are released to the environment. Ideally, complete stabilization of radioactive tailings should permanently eliminate the possibilities of:

(a) Wind and water erosion

(b) Leaching of radioactive materials and other chemicals

(c) Radon exhalation from the tailings

(d) Gamma radiation emitted from the tailings

Implicit in these objectives is the additional goal of ensuring long-term stability and isolation of the tailings without the need for continued active maintenance. These objectives are consistent with those of the proposed EPA standards for inactive uranium mill tailings disposal.(1)

\subsection{PREVENTION OF WIND AND WATER EROSION}

Wind and water erosion could be prevented by treating the tailings surface (surface stabilization), solidifying the bulk of the tailings (volumetric stabilization), by emplacing covers over the tailings (physical stabilization), or by establishing plant growth over the tailings (vegetative stabilization). Each of these is discussed in the following paragraphs. 


\subsubsection{Surface Stabilization}

Surface stabilization involves applying chemicals to the surface of the tailings to form a water-and wind-resistant crust. Surface stabilizers have been used successfully as a temporary protection on portions of dikes and tailings ponds which have dried and become dusty, and in areas where water shortage or chemical imbalance in the tailings prevents the use of cover vegetation. Surface stabilizers, however, are susceptible to physical breakup and gradual degradation and may not meet the long-term requirements for permanent stabilization of uranium mill tailings.

other complications also can arise in achieving satisfactory surface stabilization. For example, the surfaces of tailings piles seldom are homogeneous, and variables such as particle size, acidity, and moisture content affect the bonding characteristics and stability of the surface stabilizers. $(2,3)$ studies are currently being conducted to assess the possibilities of conditioning uranium mill tailings to minimize their impact if they were to migrate to the biosphere. (4) It is possible that some conditioning techniques may change the characteristics of the tailings such that degradation of surface stabilizers by the tailings would be minimized.

Among the substances used to form crusts on mill tailings surfaces and thus reduce their susceptibility to wind erosion are: resinous adhesives: lignosulfonates: elastomeric polymers; milk of lime; mixtures of wax, tar, and pitch; potassium and sodium silicates; and neoprene emulsions.

Tests were conducted by the Bureau of Mines(2) using certain chemicals (e.g., Compound Sp-400 Soil Gard, and DCA-70 elastomeric polymers) on both acidic and alkaline uranium tailings. Subsequently, the chemicals DCA-70 and calcium lignosulfonate were applied to the surfaces of the inactive uranium tailings ponds and dikes at Tuba City, Arizona, in May 1968, because low moisture conditions and high costs prohibited vegetative or physical stabilization. After 4 yr, approximately $40 \%$ of the dike surface showed disruption while the crust in pond areas was affected to a lesser extent. The major disruptions were attributed to initial penetration of the stabilizer by physical means such as vehicles, people, or animals crossing the tailings surface.

In 1969, a portion of the Vitro tailings at salt Lake City, Utah, was sprayed with tarlike material as a Bureau of Mines expeximent $(5,6)$ to achieve surface stabilization and to reduce wind erosion. The material decomposed and exposed the tailings within 2 to 3 yr after application.

"Cut-back" asphalt and asphalt-in-water emulsions also have been tested for use in protecting soils against wind and water erosion. (7) Both were shown to be effective for short 
periods of time when applied as a fine spray on sandy soils. on clay soils, the film disintegrated within a few weeks of application, apparently because of expansion and contraction of the clays during cycles of wetting and drying. The film was porous, allowed infiltration of water, and did not interfere with germination of wheat, grass, or legume seeds. The film is damaged by insects and rodents, and respraying may be necessary. Three to five years after application of the asphalt treatment. the amount of dry erodible surface area in the tested soils had increased, suggesting that asphalt treatments may not be desirable under all conditions.

More recent experiments performed for DOE are attempting to establish that surface stabilizers are useful in the long term. $(3,8,9,10,11)$ Although some asphaltic emulsions applied on tailings surfaces have degraded in less than $1 \mathrm{yr}$, covering the surface stabilizer with soil after application can extend its useful life. Nevertheless, additional data must be obtained to demonstrate long-term effectiveness of surface stabilizers.

Asphalt emulsions might be useful if mixed with a sufficient thickness of tailings or overburden material (admixing) to form a volumetric seal, as opposed to a thin coating on the tailings surface.(12) Admixing depths would have to be sufficient to minimize the potential for breakup of the volumetric seal. Recent studies have suggested that asphalt emulsion seals for uranium mill tailings may be stable for long-term applications. (11) Results of tests to determine the effects of temperature cycling (freeze-thaw), aqueous leaching, oxidation, exposure to brine solutions, and microbal attack indicate satisfactory stability of asphalt emulsions.

6.1.2 Volumetric Stabilization

Volumetric stabilization, which has been used in other mineral industry operations, involves the mixing of chemicals in sufficient quantities with tailings to produce a solidified, leach-resistant mass, much like mixing cement with sand and gravel to form concrete. The chemicals could be added in two ways: to a tailings slurry in a pipeline, or to the tailings in-situ. The in-situ method of stabilization is relatively new and research is being conducted to determine desirable materials to be added to tailings and the best techniques of application. (10,11)

One of the features claimed for this stabilization method is that all pollutant chemicals are locked in the solidified mass so they cannot be leached from the solid. Recent studies have indicated that volumetric stabilization may suffer from eventual degradation, and requires careful matching of environmental conditions, tailings, and solidifying chemicals in order to be effective. (9) 
A cover material, such as soil, might be required to protect the solidified mass from wind and water erosion, depending on the substances added to the tailings. Shallow rooted vegetation can be established after soil cover has been placed over the solidified mass. However, the long-term effect of plant root penetration into the stabilized tailings is unknown but probably would be a function of the specific chemical makeup of the solidified mass. Continued research to identify the conditions under which vegetation could thrive without affecting the integrity of volumetric stabilizers is required.

\subsubsection{Physical Stabilization}

Physical stabilization consists of isolating the contained material from wind and water erosion by covering the tailings with some type of resistant material (e.g., rock, soil, smelter slag, broken concrete, asphalt, polymeric film, etc.).

Covers of gravel or crushed rock have been shown to be effective in preventing wind erosion and allow infiltration of water without permitting substantial erosion. (13) Riprap, a cover of substantial rocks, armors the surface against erosion and may enhance growth of vegetation. $(14.15)$ clays or clayey soils would be self-healing if the tailings settled, would hold moisture, and could be a key component of a stabilizing cover.

Artificial covers, such as a layer of asphatt or a synthetic nembrane, could be placed over the tailings to reduce wind and water erosion. However, synthetic membrane materials containing plasticizers, e.g., polyvinyl chloride (PVC), are not suitable for exposed surface application because they are susceptible to damage by ultraviolet radiation. However, a thin synthetic sheet, although protected by soil from direct exposure, would have questionable mechanical strength and night not be able to maintain integrity in the long term.

In some arid regions, where the potential for successful vegetative stabilization is slight, physical stabilization may be the preferred alternative. In such areas, combinations of pit-run sand and gravel, soil, and riprap have been placed over the tailings and have been successful in preventing wind and water erosion.

An important component of physical stabilization is the proper treatment of the finished surface by such means as contour-grading and terracing. Broad range surface runoff control channels and grading are also imperative to assure that the tailings site is protected from erosion by rainstorms and floods. Such treatments can greatly reduce long-term maintenance requirements and costs. 
Both root growth and animal burrowing may provide pathways from the stabilized tailings to the environment and are therefore of concern. Research is currently under way to evaluate various chemical biobarriers for uranium mill tailings.(11) Herbicides in the form of polymeric sheets and pellets are being tested to determine their long-term ability to prohibit root growth into the tailings through the stabilizing cover material. Apparently, polymeric sheets containing herbicide are more costly than pellets, and pellets are substantially more convenient to use.

Burrowing habits of rodents and potential methods to limit burrowing are being investigated. It is believed that mechanical barriers will be more effective and less costly than chemical barriers in excluding burrowing animals from disposed tailings.

\subsubsection{Vegetative stabilization}

Vegetative stabilization involves the establishment of plant growth on the tailings or on a growing medium placed over the tailings on the premise that the root system will tend to hold the soil in place.

Criteria for plant selection provide that the plants
will:

(a) Be tolerant of local environmental conditions.

(b) Have properties that will aid in erosion control.

(c) Have propagules that are readily available.

(d) Be relatively easy to establish.

(e) Be perennials, or annuals with good reproductive capabilities.

(f) Have minimal rooting depth requirements.

(g) Be of low food value and/or palatability.

(h) Have low value as habitat for wildife.

Many species of plants require little or no maintenance after growth becomes established, an essential aspect of vegetative stabilization. Vegetation may be able to survive provided that:

(a) Evapotranspiration is not excessive.

(b) Landscapes are properly shaped. 
(c) Nontoxic soil media capable of holding moisture are provided.

(d) Irrigation and fertilization appropriate to the area are applied to initiate growth.

Growth of vegetation at sites receiving less than 10 in. of annual precipitation and with high evapotranspiration rates requires initial irrigation and fertilization. At Grand Junction, precipitation averages about 9 in. annually.

A principal disadvantage of vegetative stabilization is the possibility of uptake of radioactive elements by the plants. However, if the plants are properly selected, and if there is a sufficient depth of soil cover over the tailings, this uptake will be minimal. Barriers to root penetration are currently being evaluated.

\subsection{PREVENTION OF LEACHING}

Leaching into underground aquifers is one of the pathways that chemicals and radioactive materials might follow to the environment. The techniques that could be employed to control leaching from tailings piles include the following:

(a) Employ surface, volumetric, or physical stabilization to minimize infiltration of water, which would prevent leaching of hazardous elements into underground aquifers.

(b) Physically compact the tailings to reduce the percolation of water through the materials.

(c) Contour the drainage area and tailings surface to minimize the potential for water to penetrate into the tailings.

(d) For a new site, line the disposal area with a low-permeability membrane.

(e) Condition tailings to reduce leachability or contaminant content.

Current research of various liner systems has identified eight liner materials for continued laboratory study:

(a) Natural soil amended with sodium-saturated montmorillonite (Volclay*)

(b) Typical local clay with an asphalt emulsion radon-suppression cover

*Registered trademark. 
(c) Typical local clay with a multibarrier radonsuppression cover

(d) Rubberized asphalt membrane

(e) Hydraulic asphalt concrete

(f) Chlorosulfonated polyethylene (Hypalon*) or high-density polyethylene

(g) Bentonite, sand and gravel mixture

(h) Catalytic airblown asphalt membrane

of these materials, the rubberized and hydraulic asphalts are judged to be the two most viable candidates at this time.(11)

other studies(4) are addressing the possibility of conditioning the tailings such that if they were to leach, there would be minimal adverse impact.

\subsection{REDUCTION OF RADON EXHALATION}

Continuing research is directed toward reduction of radon exhalation from tailings piles. $(3,8,9,16,17)$ While there are materials that can seal or contain the gas on a laboratory scale, their use for permanent coverage of large areas is presently being studied.

From simplified diffusion theory estimates, it can be shown that about $13 \mathrm{ft}$ of dry soil $(18,19)$ are needed to reduce radon flux by $95 \%$, but only a few feet of soil are needed if a high moisture content in the cover material is maintained. Figure 6-1 depicts the dependence on moisture content of the effective diffusion coefficient for radon in soil. The dramatic decrease of the magnitude of the effective diffusion coefficient as the moisture content increases is responsible for the resulting reduction of radon flux.(20)

The reduction of radon exhalation flux for three soil types versus depth of cover is presented in Figure 6-2 and is based upon the theory and diffusion coefficients presented in the references cited earlier. Further research is currently under way to explore more precisely the problems associated with reducing and eliminating the exhalation of radon from radioactive tailings material. The effects of applying various surface stabilizers and varying thicknesses of stabilizing earth covers and combinations of materials are being investigated. The results may have an important impact in planning radon

* Registered trademark. 
exhalation control. However, proposed NRC standards for stabilizing inactive mill tailings require a minimum of $3 \mathrm{~m}$ of cover over the tailings. (I) The $3-\mathrm{m}$ cover was assumed to be sufficient to meet proposed radon release requirements in remedial action cost estimates presented in this report.

Investigations described in paragraph 6.1 have shown that cationic asphalt emulsions can be effective in large-scale applications in reducing radon fluxes to required levels.(II)

studies of multilayer physical stabilization systems presently in progress are directed at identifying cost effective cover systems to satisfy proposed EPA standards for disposal. (1) These studies have indicated that, under a given set of conditions, a single-material cover would have to be up to about $24 \mathrm{ft}(7.2 \mathrm{~m})$ thick to reduce radon flux to the required $2 \mathrm{pCi} / \mathrm{m}^{2}-\mathrm{s}$. In contrast, a well designed multilayer cover system of less than $8.5 \mathrm{ft}(2.6 \mathrm{~m})$ thickness under the same conditions could satisfy the radon flux requirement.

6.4 REDUCTION OF GAMMA RADIATION

A few feet of cover material have been shown to be sufficient to reduce gamma radiation to background levels.

The reduction of gamma exposure rates resulting from a packed earth covering is given in Figure $6-3 .(8,21)$ Two feet of cover reduce the gamma levels by about two orders of magnitude. Therefore, an average cover thickness of $3 \mathrm{~m}$ should reduce gamma levels from the tailings to background. Multilayer and asphalt cover systems currently under investigation have been shown to effectively attenuate gamma levels to acceptable ranges.

\subsection{ASSESSMENT OF APPLICABILITY}

Available data indicate that the methods previously used at the inactive sites in attempts to stabilize uranium tailings have not been totally satisfactory and that long-term solutions to uranium tailings site radiation problems have yet to be clearly demonstrated. Consequently, new or combination methods of stabilization are being evaluated. The present remedial action options include physical stabilization of the tailings with at least $3 \mathrm{~m}$ of well designed soil cover and $0.3 \mathrm{~m}$ of riprap. This action will reduce ganma radiation and wind and water erosion, substantially reduce radon exhalation, minimize infiltration, and allow reestablishment of native vegetation.

If remedial actions are taken, combinations of the methods described in this chapter for preventing erosion, leaching to ground water, radon exhalation, and gamma radiation will be implemented based on climatic, hydrogeological, economic, and demographic factors. The method of stabilizing uranium mill 
tailings whereby $3 \mathrm{~m}$ of well-engineered cover is placed on the pile is apparently the primary method currently available that satisfies both U.S.(1) and Canadian(22) regulatory requirements. 


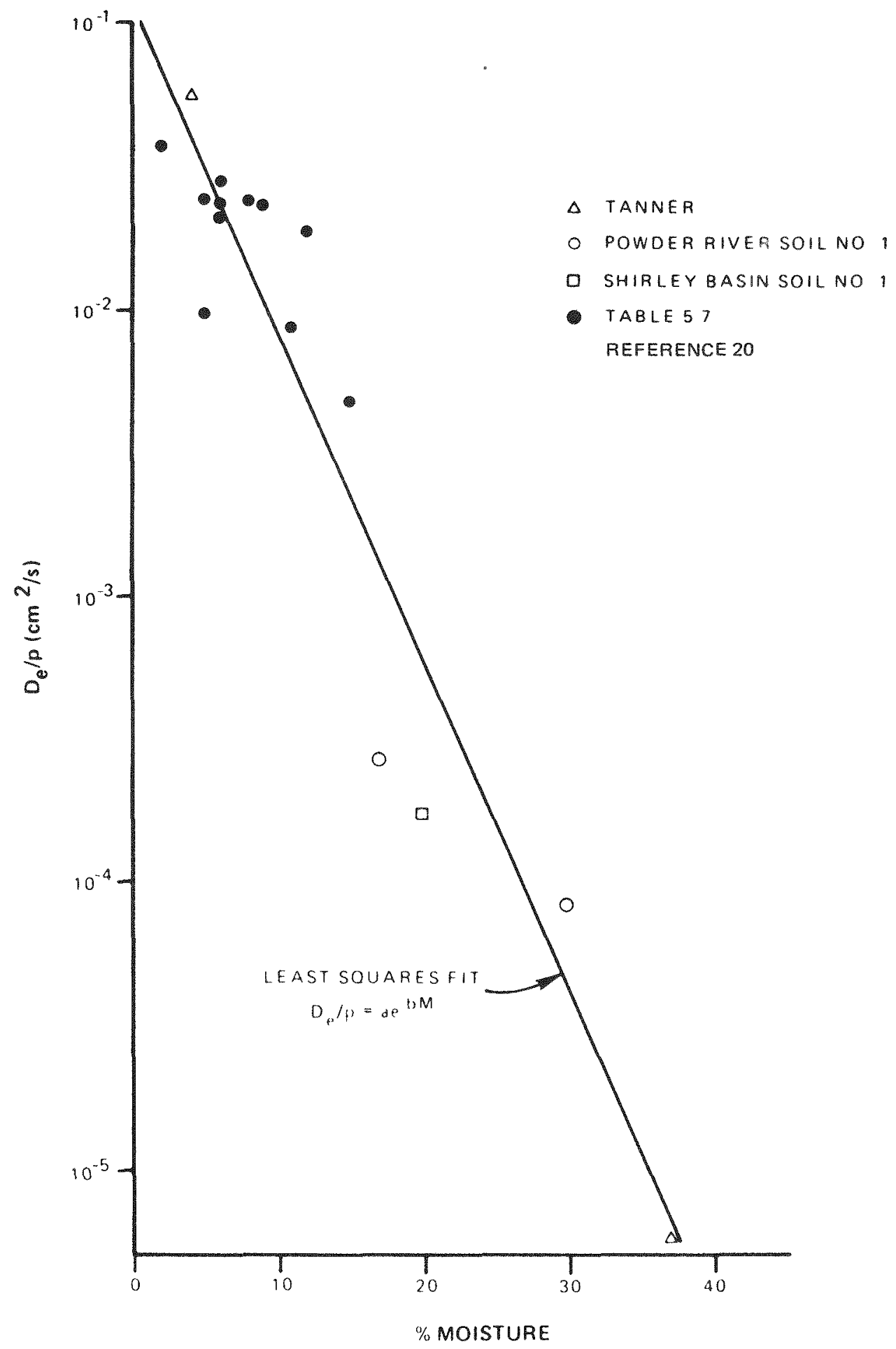

FIGURE 6-1. EXPONENTIAL MOISTURE DEPENDENCE OF THE DIFFUSION COEFFICIENT 


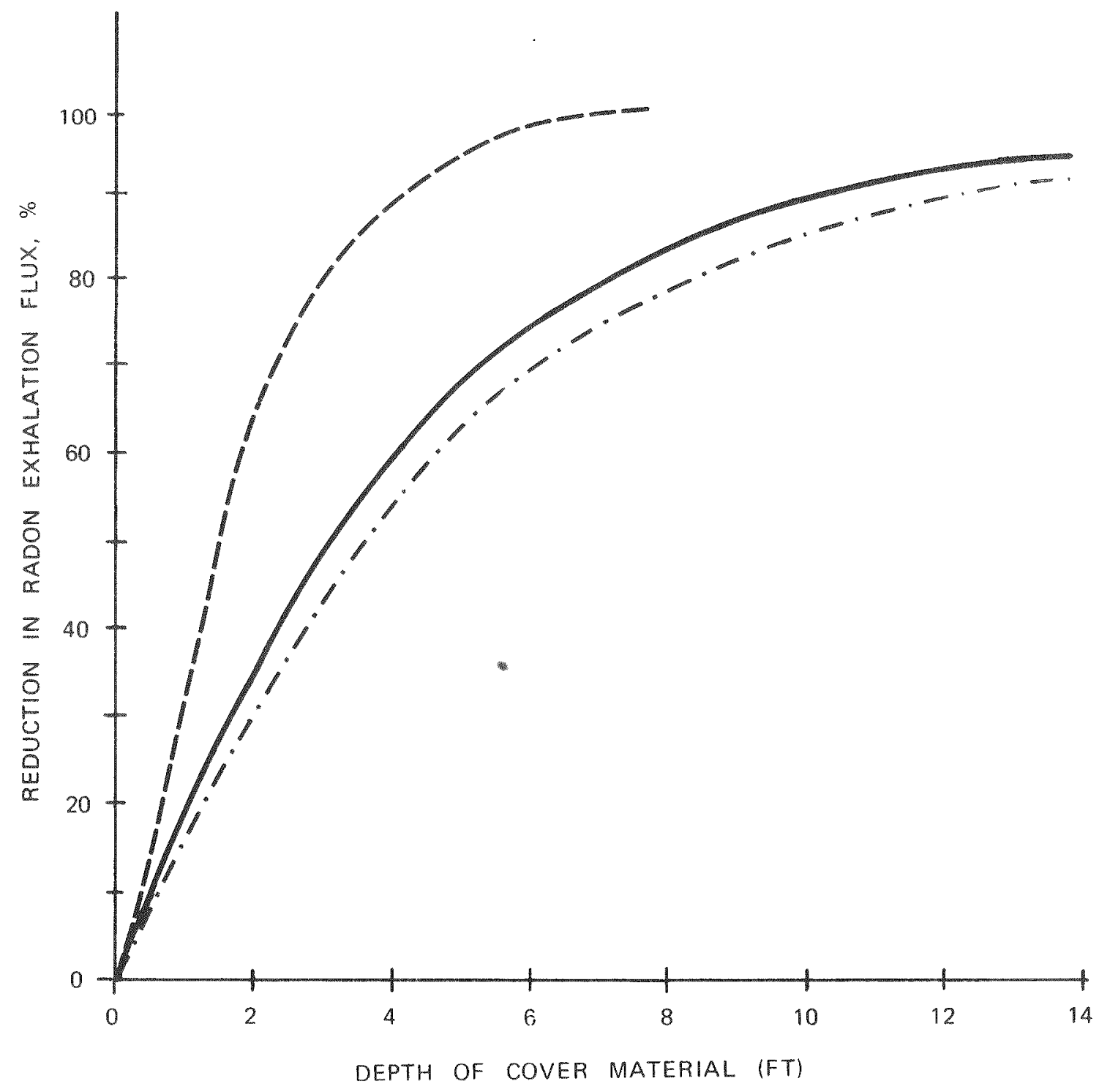

LEGEND

RESULT FOR SOIL (USED IN THIS EVALUATION)

- $\cdots$ RESULT FOR DRY SAND

$=-$ RESULT FOR CLAY

FIGURE 6-2. REDUCTION OF RADON EXHALATION FLUX WITH DEPTH OF COVER 
Toro.

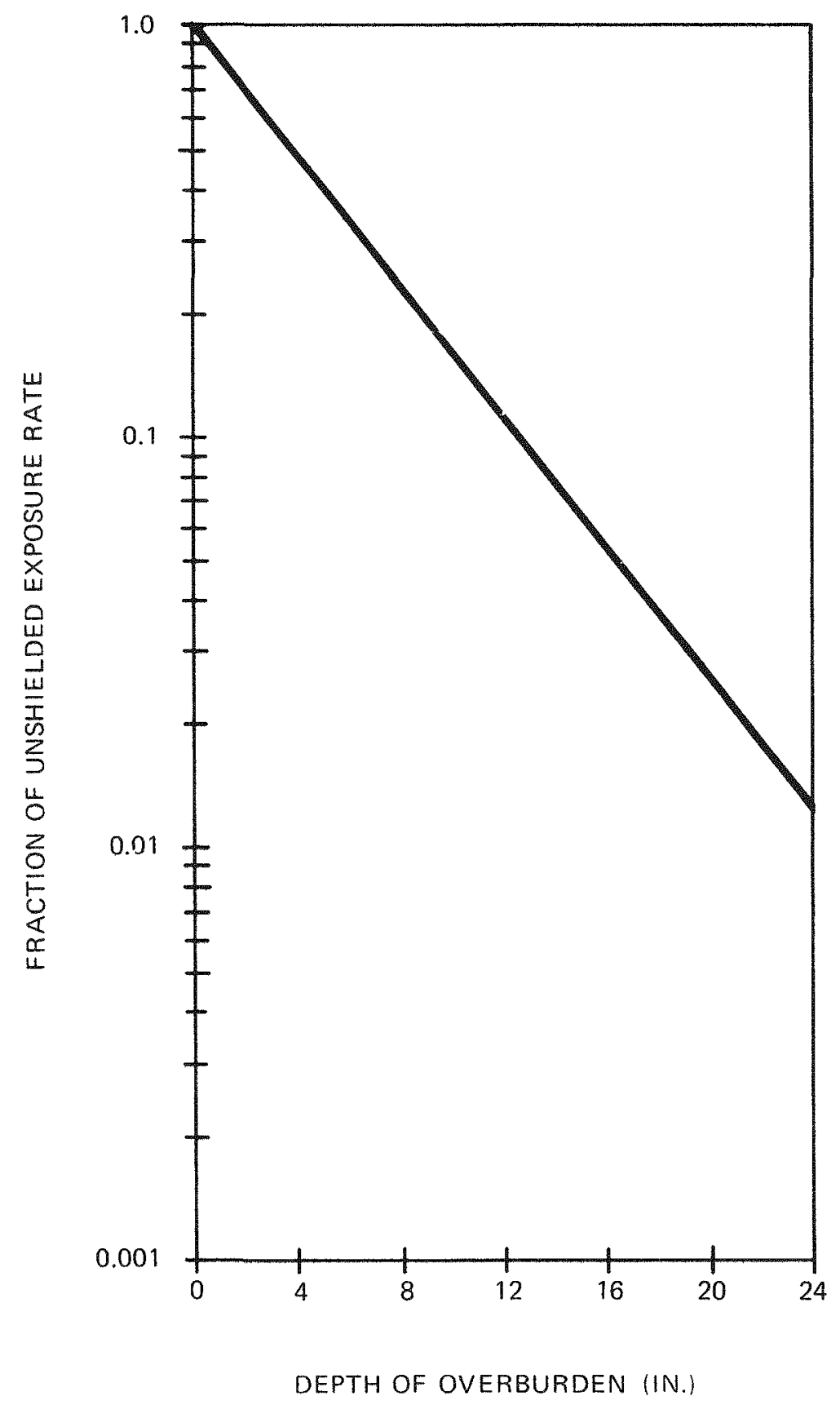

FIGURE 6-3. REDUCTION OF GAMMA EXPOSURE RATE RESULTING FROM PACKED EARTH SHIELDING 


\section{CHAPTER 6 REFERENCES}

1. "Proposed Disposal Standards for Inactive Uranium Processing Sites, Invitation for Comment": U.S. Environmental Protection Agency; Federal Register: Vol 46, No. 6: p. 2556; Jan 9, 1981 .

2. "Methods and Costs for Stabilizing Fine Sized Mineral Wastes"; Bureau of Mines Report of Investigation; RI7896: 1974.

3. P.L. Koehmstedt, J.N. Hartley, and D.K. Davis; "Use of Asphalt Emulsion Sealants to Contain Radon and Radium in Uranium Tailings"; BNWL-2190; Battelle Pacific Northwest Laboratories; Richland, Washington; Jan 1978.

4. D.R. Dreesen and J.M. Williams; "Monthly Report, November 1980"; Los Alamos Scientific Laboratory, Environmental Science Group.

5. R. Havens and K.C. Dean; "Chemical Stabilization of the Uranium Tailings at Tuba City, Arizona"; U.S. Department of the Interior, Bureau of Mines; 1969.

6. K.C. Dean, et al.; "Progress in Using and Stabilizing Mineral Wastes"; Salt Lake Metallurgical Research Center; 1970 .

7. W.S. Chepil; "Effects of Asphalt on some Phases of Soil Structure and Erodibility by Wind"; Soil Science Society of America Proceedings 19:125-128; 1955.

8. P.J. Macbeth, et a 1.: "Laboratory Research on Tailings Stabilization Methods and Their Effectiveness in Radiation Containment"; GJT-21; Ford, Bacon \& Davis Utah, Inc.; Salt Lake City, Utah: Apr 1978.

9. B.J. Thamer, et al.: "Radon Diffusion and Cover Material Effectiveness for Uranium Tailings Stabilization": FBDU258; Ford, Bacon \& Davis Utah, Inc; Salt Lake City, Utah; May 1980.

10. J.N. Hartley, P.L. Koehmstedt, and D.J. Esterl; "Asphalt Emulsion Sealing of Uranium Mill Tailings": Battelle Pacific Northwest Laboratories; Richland, Washington: 1979.

11. T.D. Chikalla, Compiler: "Quarterly Uranium Tailings Report, October through December 1980"; Pacific Northwest Laboratory; Feb 1981 . 
12. J.N. Hartley, et al.; "Uranium Mill Tailings stabilization": Feb 1980; presented at Waste Management 80; Tucson, Arizona: Mar 10-14, 1980.

13. W.S. Chepi1, N.P. Woodruff, F.H. Siddoway, D.W. Fryrear, and D.V. Armburst; "Vegetative and Nonvegetative Materials to Control Wind and Water Erosion": Soil Science Society of America Proceedings 27:86-89; 1963.

14. J.D. Nelson and T.A. Shepherd; "Evaluation of Long-Term stability of Uranium Tailing Disposal Alternatives"; Civil Engineering Department, Colorado state University. Fort Collins, Colorado; prepared for Argonne National Laboratory; Apr 1978.

15. D.R. Dreesen, M.L. Marple, and N.E. Kelley; "Containment, Transport, Revegetation, and Trace Element studies at Inactive Uranium Mill Tailings Piles"; Proceedings of Symposium on Uranium Mill Tailings Management, Colorado State University, Fort Collins, Colorado; Nov 20-21, 1978.

16. G.W. Gee, et al.; "Interaction of Uranium Mill Tailings Leachate with Soils and Clay Liners"; NUREG/CR-1494; Battelle Pacific Northwest Laboratories, Richland, Washington; May 1980.

17. P.J. Macbeth, et a1.; "Research on Radon Gas Diffusion and Attenuation from Uranium Mill Tailings"; Paper Presented at International Conference on Uranium Mine and Mill Tailings Disposal; Vancouver, B.C., Canada; May 19-21, 1980.

18. A.B. Tanner; "Radon Migration in the Ground: A Review"; The Natural Radiation Environment; J.A.S. Adams and W.M. Lowder, eds; University of Chicago Press; pp. 161-190; 1964.

19. H.W. Kraner, G.L. Schroeder, and R.D. Evans; "Measurements of the Effects of Atmospheric Variables on Radon-222 Flux and Soil-Gas Concentrations": The Natural Radiation Environment; J.A.S. Adams and W.M. Lowder, eds; University of Chicago Press; 1964.

20. V.C. Rogers, et al.; "Characterization of Uranium Tailings Cover Materials for Radon Flux Reduction": NUREG/CR-1081 and FBDU-218-2; Jan 1980 .

21. K.J. Schiager; "Analysis of Radiation Exposures on or Near Uranium Mill Tailings Piles"; Radiation Data and Reports; Vol 15; July 1974.

22. K.E. Hanney, et al.; "Reclamation concepts and Practice for Uranium Tailings Impoundments": Paper Presented at International Conference on Uranium Mill Tailings Disposal; Vancouver, B.C., Canada; May 19-21, 1980. 


\section{CHAPTER 7}

OFF-SITE REMEDIAL ACTION 
CHAPTER 7

OFE-SITE REMEDIAL ACTION

ongoing surveys conducted by the colorado Department of Health in the vicinity of the Grand Junction site have identified locations away from the site where tailings have been used. A total of over 29,000 location numbers have been assigned in Grand Junction. At 1,284 of those locations, tailings were found within $10 \mathrm{ft}$ of the structures and against or under structures. An additional 2,518 locations were discovered where tailings were found under and away from structures. At 2.385 locations, tailings were discovered at distances greater than $10 \mathrm{ft}$ from structures. (1)

Tailings use locations that fall into the first two categories described above are currently being decontaminated under the Grand Junction remedial action program, authorized under separate legislation. (2) It may be possible, however, that half of these locations may require further remedial action under the criteria proposed by the EPA. (3)

off-site locations where tailings have been used and are located greater than $10 \mathrm{ft}$ from structures are not covered under the Grand Junction remedial action program, but will require cleanup. It is also expected that streets, sidewalks, and sewers may be included in remedial actions conducted under PL 95-604 since urban renewal of downtown Grand Junction (estimated to be 7 blocks long and 3 blocks wide) involved the use of substantial quantities of tailings. In addition, it is believed that virtually all public construction in Grand Junction during the $1960^{\prime} \mathrm{s}$ made use of the tailings. (4)

Since adequate information was not available on each of these structures, nor is the extent of tailings use at off-site locations known with any certainty, no detailed estimate of remedial action costs for off-site tailings use locations in Grand Junction was attempted. Nevertheless, assuming an average cleanup cost of $\$ 10,000$ per tailings use location, the total cost for off-site remedial action at Grand Junction might be $\$ 60,000,000$. No effort was made to estimate the cost of decontaminating the downtown area.

The cost estimated above is not included in the cost summary of chapter 9, since it is so large as to completely dominate the cost estimate for remedial action at Grand Junction. Yet it is noted that under proposed remedial action standards, cleanup of off-site properties in Grand Junction will be required unless exceptions are sought and granted. 
1. Bud Franz; Colorado Department of Health: personal communication; Apr 23, 1981 .

2. Office of the U.S. Surgeon General; Department of Health, Education and Welfare; 10 CFR 12; July 1970.

3. Environmental Protection Agency; "Proposed Disposal standards for Inactive Uranium processing sites: Invitation to Comment"; Federal Register, Vol 46, No.6, pp. 2556-2563; Jan 9, 1981 (also 40 CFR 192).

4. Don Warner, Planning Department, Grand Junction: personal communication: Apr 24, 1981. 
CHAPTER 8

DISPOSAL SITE SELECTION 


\section{CHAPTER 8}

\section{DISPOSAL SITE SELECTION}

One of the remedial actions considered in this engineering assessment would involve moving the Grand Junction tailings to a disposal site for long-term stabilization. potential disposal sites were located based on presently proposed regulations. With the presently proposed regulations requiring $3 \mathrm{~m}$ of cover for the long-term stabilization of tailings, potential sources of these large amounts of cover materials have veen located for each of the disposal options. The relative locations of actual sources of cover material to the various disposal sites will have an impact on the option costs.

\subsection{CRITERIA FOR DISPOSAL}

In 1980 a report consisting of input from the colorado Department of Health, the Colorado Geoloyical survey, and the state Attorney General's office, which addressed the generation and disposal of hazardous waste within the state of Colorado, was issued(I) to the Colorado state Legislature. According to the report, uranium mill tailings might be considered hazardous waste. The recommendations of the report stated that the evaluation of potential tailings disposal sites should include the collection of extensive hydrologic, geologic, and physiographic data on the particular site and that the following criteria should be followed in the selection process:

(a) Contaminants should not degrade ground or surface water quality.

(b) The disposal site should be at least 1 mi from the probable maximum flood plain.

(c) The disposal site should be located in suitable geologic strata.

(d) Excavations should be developed completely within the bedrock units and sealed with an engineered impermeable cap.

(e) The disposal site should be in seismically and structurally sound areas.

(f) Geochemical reactions between the host rock and the waste should be consiclered.

The general intents of these recommendations have been satisfied in the selection of candidate disposal sites which are described below. However, many details have not been addressed 
since these recommendations were not available at the time this work was conducted. Due to this fact, and the fact that the Federal Government is responsible for disposal site selection with input from the state, these disposal sites should be considered as preliminary.

State and federal agencies, private individuals, and industries were contacted to locate possible disposal sites for the Grand Junction tailings. In addition to those sites suggested by outside sources, other sites having characteristics compatible with safe disposal were sought and identified. In the original report, 18 disposal sites were considered. However, since 1977, 4 sites have been added and 2 deleted for a total of 20 disposal sites under consideration. A preliminary reconnaissance survey was made of each of these sites. Seven of the sites were selected for cost estimate studies and are included as Options II through VIII in chapter 9.

Two of the originally selected sites are no longer considered viable: site 10 because of steepness of slopes allowing possible headward erosion, and site 9 because of site inaccessibility.

Figure 8-1 shows the relative locations of the possible disposal sites. Table 8-1 lists the names of each alternative disposal site studied and the road distance of each from the present Grand Junction tailings site. Of the 20 sites considered, only 7 have been considered as options because the balance have one or more of the following disadvantages: possible residential development, excessive haul distance, steepness of terrain, possibility of encroachment on the site, difficulty of handiing surface hydrology (too much upslope drainage and watershed area location), or lack of sufficient material for stabilization cover.

Each of the sites included in the options was evaluated to a limited extent on the basis of hydrology, meteorology, ecology, and economics. The site evaluations consisted of literature surveys and limited on-site evaluations. The hydrologic and meteorologic conditions were assessed with regard to such factors as wind and water erosion, water contamination, flooding and drainage characteristics, precipitation, exposure to sun and wind, type and depth to bedrock, and location of confined aquifers. Special consideration was given to drainage basin configuration, subsurface and surface drainage, and natural storage basin features. The geologic examination addressed stability problems and soil characteristics, such as evidence of slides or faults and types of unconsolidated and bedrock materials. The ecological study evaluated land use potential, animal habitats, proximity to population centers, and aesthetic considerations. Economic considerations included preliminary estimates of support facilities such as highways, railroads, distance from the Grand Junction site, and the 
extent of site preparation and long-term maintenance required at the site.

Since there is a railroad line adjacent to the Grand Junction site and to the two tailings sites at Rifle, Colorado, $63 \mathrm{mi}$ east of Grand Junction, a site was located that could serve as a disposal area for these three sites in combination or singly. Private, state, and federal lands were included in the search for acceptable alternative sites.

The originally proposed disposal site near DeBeque is no longer considered viable due to the difficult access to the site. However, in order to have the option of aisposing of the Rifle and Grand Junction tailings at a single location which is approximately nidway between Rifle and Grand Junction, an unspecified site in the DeBeque vicinity was evaluated and treated as a cost option. Even though the site is undefined, it is assumed to meet the generic qualifications of a disposal site.

Returning the Grand Junction tailings to the mines from which the ores were obtained is not feasible. The ore treated at the mill came from many mines scattered over a wide area, and many of these mines contributed only a few hundred tons. Costs and logistics involved in hauling make such a proposal too impractical to consider.

\subsection{DESCRIPTIONS OF DISPOSAL SITES CONSIDERED AS OPTIONS}

\subsubsection{Whitewater Hill, Site 14 (Option II)}

The Whitewater Hill site is located $6.5 \mathrm{mi}$ southeast of the pile and south of the old whitewater Road, in an area currently under lease by Mesa County and the city of Grand Junction for use as a sanitary landfill. It is $0.5 \mathrm{mi}$ south of U.S. Highway 50 and southeast of the community known as orchard Mesa. Access to the site would be over the bridge spanning the Colorado River, southeast on U.S. Highway 50, and then onto the site. No special haul roads would need to be constructed. The closest housing is $0.5 \mathrm{mi}$ from the site.

Because of the steep terrain, development of a site lower in the drainage than originally considered would result in a tailings dam less high but would only minimally increase the upstream drainage.

Annual precipitation is about 9 in. at this site. Soils in the area are generally gravelly loams. In fact, a gravel pit is located immediately adjacent to the landfill. Therefore, the gravel cap could be obtained from the immediate area. If the loams were applied wet and compacted they might be adequate for cover material. some less gravelly areas of loam are also associated with this mapping unit. Clays could be obtained from 
local pits to be mixed with the soils if the loams did not prove adequate.

The main advantages of the site are the short haul distance of $6.5 \mathrm{mi}$ and the minimal traffic that would be encountered using this route. A disadvantage of this site would be the possible interference with sanitary fill operations. The soils mapped in this area are underlain by sandstone and basalts which have a relatively high permeability.

\subsubsection{Grasso Mine Road, Site 2 (Option III)}

The Grasso Mine Road site is located $10.5 \mathrm{mi}$ north of Grand Junction on U.S. Bureau of Land Management (BLM) Iand in an area where 26 Road and $L$ Road would intersect. It is $0.5 \mathrm{mi}$ west of the Grasso Mine Road, a gravel road that leads in a northeasterly direction from the Government Highline Canal at approximately the intersection of 25 Road and $J$ Road. The site is about $2.25 \mathrm{mi}$ northeast of this intersection on the east side of a ridge that separates persigo wash from the wash paralleling Grasso Mine Road.

Access would be over paved public highways, a bridge over the Government Highline Canal, the Grasso Mine Road, and then on a haul road that would have to be constructed to the site. The site is remote from the public and at least $2 \mathrm{mi}$ from the nearest habitation but is used occasionally by recreational vehicles.

The disposal site lies at an elevation of $4,960 \mathrm{ft}$. It is on the lee side of the local terrain so that the stabilized tailings would be protected from winds blowing up (in an easterly direction) the Grand Valley. The estimated annual precipitation is 9 in.

Soils in the area consist of deep well-drained loams, silty clays, and silty clay loams that were formed from the underlying shale. There is adequate material available for stabilization cover. Gravel cap material would probably have to be obtained from gravel terrace deposits along the Colorado River. Hauls of $20 \mathrm{mi}$ would be necessary. There is a possibility that old gravel deposits capping the ridges could be found closer to the site. Gravel that underlies the tailings site might also be used for stabilization. An advantage of this site is that it is underlined by Mancos shale, which has a low permeability and would protect the underlying aquifers. The site would occupy an area of approximately 60 acres to an average depth of 21 ft. Haulage to the site is proposed to be by truck or truck-trailer combination.

8.2.3 Indian Wash, Site 7 (Option IV)

The Indian Wash site is located on BLM land $9.5 \mathrm{mi}$ northeast of the tailings pile and $2.5 \mathrm{mi}$ northeast of the 
administration building at Grand Junction's Walker Field airport. This is an area between the Government Highline Canal and the Book cliffs. Access would be over paved public roads east of Grand Junction, crossing the Government Highland Canal and Interstate 70 near Baseline Road and 29 Road. From this intersection to the site, a haul road would be constructed. The site is remote from the public and at least $2 \mathrm{mi}$ away from any human habitation, but the area is occasionally used by recreational vehicles.

The site lies at an elevation of 5,040 ft. It has a southeasterly exposure and the topography is similar to site 2 , Grasso Mine Road. This site is in a badlands area developed on shale.

Since soil development in badlands areas is generally shallow, the full $3 \mathrm{~m}$ of cover could probably not be obtained from the site itself. The decomposed shale and fine-grained soils in the immediate area could be used for cover. Drainages often contain large amounts of sediment that also could be used as cover. Gravel for this site would also need to be obtained from along the colorado River unless old sediment deposits could be located closer to the site. The tailings would occupy an area of approximately 70 acres to an average depth of $18 \mathrm{ft}$.

Advantages include the remoteness of the site, the improbability of encroachment on the site or of its being used for any other purpose, and the availablity of stabilization cover material. The site is underlain by Mancos Shale which, with its low permeability, would protect the underlying aquifers. Disadvantages are the length of a new haul road required, exposure to the sun and wind, and upslope drainage.

\subsubsection{East Orchard Mesa, Site 19 (Option V)}

The East orchard Mesa site was added because it is located on gentle slopes and therefore would be easy to develop. It is in a remote area on BLM land $11.5 \mathrm{mi}$ southeast of Grand Junction at an elevation of $5,140 \mathrm{ft}$. The site is $3 \mathrm{mi}$ east of an old airfield now used as a dragstrip located near the intersection of U.S. Highway 50 and 32 Road. The location is at the head of a wash which drains toward the Colorado River.

Access from the present tailings site would be by means of public paved highways to the aragstrip; then on a specially built haul road to the site. The closest human habitation is $2.5 \mathrm{mi}$ from the site. This is the most remote of all sites considered and is used for seasonal grazing of cattle. In the immediate vicinity of the site there are several other sites that are almost identical and which could be developed into suitable disposal areas. 
The average annual precipitation is estimated to be 9 in. soils in this area are generally deep loams and stony loams. Material from the loany areas might serve as good cover. It is unlikely that all cover materials will be obtained from the site itself, but sources in the area would be adequate. The stony loams underlying the site area may be a possible source for a gravel cap. If they do not prove to be adequate, gravel pits to the west along the Gunnison River at a distance of about 4 to $6 \mathrm{mi}$ might be alternate sources.

Advantages include the remoteness of the site, the availability of stabilization cover material, and the site's location at the head of a drainage basin resulting in no upslope drainage problems. Disadvantages are the haul distance from the site and the length of a new haul road required. The soils mapped in this area are apparently underlain by sandstones and basalts which have a relatively high permeability.

\subsubsection{North Whitewater Creek, site 20 (option VI)}

The North Whitewater Creek disposal site is located on private land about $11 \mathrm{mi}$ from the tailings. Access to the site is via U.S. Route 50 south to Aqueduct Road, then east for $2.4 \mathrm{mi}$. The site is located $0.6 \mathrm{mi}$ south of the road at this point; development of a haul road would be necessary. The site is located on a ridge between two drainages at an elevation of 4,860 ft above sea level.

Average annual precipitation for this site is 9 in. The area is typified by residual soils formed in shales on upland hills and ridges. The soils are generally silt or silty clay loams from 10- to 20-in. thick. Therefore, it is not likely that the full $3 \mathrm{~m}$ of cover could be excavated from the site itself. Additional cover could be obtained from the immediate area. Several areas within $1 \mathrm{mi}$ of the site are mapped as stony loams which might serve as a source of gravel cap. Developed gravel pits from 3 to $6 \mathrm{mi}$ from the site are also potential sources. The soils in this series are underlain by impermeable shales.

Advantages of this site include remoteness from population certers, little upslope arainage, and a shale bedrock. Disadvantages are the location on a ridge that might require diking on more than one side.

\subsubsection{East Coal Canyon, Site 21 (Option VII)}

The East Coal Canyon disposal site is located on BLM land about $11 \mathrm{mi}$ from the tailings. Access to the site would be over paved roads east of Grand Junction to U.S. Routes 6 and 24 to the Gearhart Mine Road, then over $1.1 \mathrm{mi}$ of jeep road. This road would have to be upgraded to accommodate heavy truck traffic. The site is located on a drainage divide at an elevation of about $5,600 \mathrm{ft}$. 
While this is an area characterized by little if any soil development, some cover could be obtained from the area. The larger part of the cover would need to be obtained from local contractors, probably requiring hauls of from 5 to $10 \mathrm{mi}$. Gravels would have to be obtained from along the colorado River south of the site, necessitating hauls of from 5 to $8 \mathrm{mi}$.

Advantages include the remoteness of the site and the improbability of development. The unavailability of cover material is a disadvantage as is the underlying sandstone which is relatively permeable.

\subsubsection{Unspecified Site Near DeBeque, Site 22 (Option VIII)}

An unspecified disposal site near DeBeque could be located in a basin about $35 \mathrm{mi}$ from the tailings. The terrain in the area is rugged with bedrock outcrops, but with enough soil material to provide stabilization cover. Rainfall is estimated to be 10.5 in. annually. The land is used for seasonal grazing of cattle and appears to be a shelter area for wildife. An advantage of the site is the low population density in the area. This site could be used for disposal of the Rifle tailings as well as the Grand Junction tailings. 
TABLE 8-1

SITES EVALUATED FOR DISPOSAL OF GRAND JUNCTION TAILINGS

\begin{tabular}{|c|c|c|c|}
\hline $\begin{array}{c}\text { Site } \\
\text { Identification } \\
\text { Number } \\
\end{array}$ & $\begin{array}{l}\text { Cost } \\
\text { Option } \\
\text { Number } \\
\end{array}$ & $\begin{array}{l}\text { Road } \\
\text { Distance } \\
\text { From Pile } \\
\quad(\mathrm{mi}) \\
\end{array}$ & Site Name \\
\hline 1 & -- & 13.0 & Adobe Creek \\
\hline 2 & III & 10.5 & Grasso Mine Road \\
\hline 3 & -- & 8.0 & Grasso Mine Road (Central) \\
\hline 4 & -- & 7.5 & Grasso Mine Road (East) \\
\hline 5 & -- & 6.7 & West Leach creek. \\
\hline 6 & $-\infty$ & 5.3 & Walker Field \\
\hline 7 & IV & 9.5 & Indian Wash \\
\hline 8 & -- & 8.5 & Moulton Valley \\
\hline 9 & -- & 35.0 & DeBeque \\
\hline 10 & -- & 11.5 & East Orchard Mesa \\
\hline 11 & -- & 11.0 & East orchard Mesa \\
\hline 12 & $-\infty$ & 10.5 & East Orchard Mesa \\
\hline 13 & -- & 9.5 & East Drag strip \\
\hline 14 & II & 6.5 & Whitewater Hill \\
\hline 15 & -- & 6.0 & Whitewater Hill \\
\hline 16 & -- & 7.0 & Billings Mesa \\
\hline 17 & - & 5.2 & Nothoroughfare Canyon \\
\hline 18 & -- & 20.0 & Dominguez Reservoir \\
\hline 19 & $\mathrm{~V}$ & 11.5 & East Orchard Mesa \\
\hline 20 & VI & 11.0 & North Whitewater Creek \\
\hline 21 & VII & 11.1 & East coal Canyon \\
\hline 22 & VIII & 35.0 & DeBeque (unspecified site) \\
\hline
\end{tabular}

$360-09 \operatorname{Rev} 6 / 80$ 


\section{CHAPTER 9}

REMEDIAL ACTIONS AND COST-BENEFIT ANALYSES 
CHAPTER 9

\section{REMEDIAL ACTIONS AND COST-BENEFIT ANALYSES}

Various renedial action options for the tailings on the Grand Junction site were identified and investigated. The remedial actions presented are those considered to be the most realistic and practical when evaluated in regard to the present remedial action criteria, technology, and information available. Costs and benefits have been estimated and evaluated for each option considered.

The procedures for decontaminating inactive mill tailings sites have not been well established. Although remedial action criteria have been established tentatively, the methodology of satisfying such standards is still in a state of change. The position has been taken that radiological and industrial safety should be pursued to the extent necessary to satisfy remedial action criteria and to provide assurance to the public and to workers. The public should feel comfortable with the methodologies used.

Since each state where tailings are located must participate in funding for remedial action, it is fair to assume that there will be very strong pressures to assure that costs will be limited to a moderate total.

Remedial actions designed to meet the EPA interim remedial action criteria wexe investigated. Seven possible disposal sites, identified in chapter 8 , were evaluated in terms of the cost of disposal. Although each alternative disposal site has unique characteristics that were considered in estimating costs, great care must be exercised in the use of these site-specific cost estimates since there are insufficient data and information to characterize the sites completely for estimating site development costs.

The process of obtaining the necessary permits and the associated costs are considered to be included in the various ayency budgets and are not included in this report. Similarly. the tailings sites, the proposed disposal sites, and related gravel or clay material borrow pits have been treated as public lands with no acquisition costs included.

Costs for future maintenance and radiological monitoring at the location of the tailings are not included in this estimate. Funding for such future costs is assumed to come from separate contracts administered by the Federal Government.

An extensive off-site remedial action program has been under way in the Grand Junction area under authority of separate legislation. Presently, all contaminated materials from 
off-site locations are deposited on the adjacent state-owned repository area. On-site stabilization of the tailings requires that the repository be cleaned up and all contaminated materials (about $400,000 \mathrm{yd}^{3}$ will yet be delivered) be placed on top of the tailings pile before the required $3 \mathrm{~m}$ of cover material is placed.

The options for disposal at the sites would provide for the relocation of all debris and contaminated material from the tailings and millsite areas, repository area, and windblown areas. Thus, in all of the disposal options, the entire site and repository areas would be left free of any tailings or contaminated materials. It is recognized, however, that provisions must be made for continued disposal of contaminated materials resulting from cleanup of off-site locations. The area to be decontaminated at the Grand Junction site is shown in Figure $9-1$.

A discussion of the concepts involved in tailings stabilization and their applicability to the Grand Junction site has been detailed in chapter 6 . It is assumed that vegetation will be planted if the tailings are stabilized on site. However, for disposal options, a riprap cap on top of $3 \mathrm{~m}$ of cover material is assumed to suffice for erosion control in lieu of vegetation.

9.1 STABILIZATION OF THE TAILINGS ON SITE WITH A 3-METER COVER (OPTION I)

In this section the conceptual design of the option to stabilize the Grand Junction tailings piles is discussed, and the estimated cost of the corresponding remedial actions presented.

\subsubsection{Conceptual Design}

Stabilization of the Grand Junction tailings on the present site may not be a viable option because of its proximity to the city of Grand Junction. This option provides a means of comparison between this report and similar reports for other mill tailings sites. Therefore, in preparing the cost estimate for this option, the possible problem of migration of contamination via ground water was not considered, and the cost does not include the placement of a clay or synthetic liner under the tailings. The cost of this option would increase significantly if the liner were required.

The state repository windblown tailings and the millsite and ore storage areas would be cleaned up and the resulting contaminated materials placed on top of the existing tailings. Millsite buildings would be demolished and placed on the pile. An average of $2 \mathrm{ft}$ of material would be removed from the millsite and 3 ft of material removed from $70 \%$ of the ore storage area. An average of $6 \mathrm{in}$. would be scraped off of 
windblown areas. All areas would be backfilled to natural grade and landscaped to match original conditions.

The tailings site would be leveled, graded, and stabilized with $3 \mathrm{~m}$ of cover material, which was assumed in these cost evaluations to be adequate to reduce radon flux to the required $2 \mathrm{pCi} / \mathrm{m}^{2}-\mathrm{s}$. Low permeability soil for cover material can be obtained at distances of 5 to $10 \mathrm{mi}$ from the site.

The final shape of the surface of the tailings pile generally would be the same as the present surface of the pile. The surface would slope gently toward the west. At the river's edge the dike would slope up from the river or surrounding land at a $50 \%$ maximum slope. The presence of the river on the south side of the site makes it impossible to meet the NRC-proposed rule for a flat slope of not greater than $20 \%$ (1) if the tailings are stabilized at the present site. To increase the protection of the pile from possible flooding of the colorado River, a new dike would be reinforced with a 3 -ft-thick layer of riprap at elevations between 4,556 and 4,575 ft above sea level. This protection would eliminate the potential of surface erosion by the river's regular or maximum flood flows, although it would not prevent the water table from rising into the pile.

If vegetative stabilization is selected for surface erosion control, all of the newly stabilized areas would be seeded with self-regenerating vegetation native to the area. This vegetation would be able to survive the summer months without irrigation after an initial establishment period of about 8 mo.

If the Grand Junction site were to be stabilized in place, it would probably have limited future use. The sight of the resulting 20-ft-high stabilized pile would be objectionable, and property and land values in the area would continue to be depressed.

\section{1 .2 Costs for stabilization in place}

As shown in Table 9-1, the cost for stabilization at the Grand Junction site is estimated to be $\$ 10,200,000$. Costs include cleaning up of windblown tailings, millsite, ore storage areas, and the state repository, covering all contaminated materials with $3 \mathrm{~m}$ of cover, contouring the surface, establishing vegetation or covering with riprap, and reclaiming of all areas.

\subsection{REMOVAL OF TAILINGS AND ALL CONTAMINATED MATERIALS FROM THE SITE (OPTIONS II THROUGH VIII)}

Options II through VIII would provide for the complete removal of all tailings, contaminated soil, existing stabilization cover, buildings, materials, and rubble from the tailings site to a disposal site. Also included would be all of the 
contaminated material from the state repository. The amount of soil to be removed depends on the depth of contamination (see Paragraph 3.4.5). Removal to averages of 3 ft of subsoil beneath the tailings pile, 2 ft of subsoil below the former millsite, 3 ft below the ore storage areas, and I ft below the state repository will apparently reduce residual radium concentration to less than the required $5 \mathrm{pCi} / \mathrm{g}$ above background levels. Finally, the site would be backfilled to natural grade, vegetation would be established, and the site would be released for unrestricted use.

\subsubsection{Excavation and Loading of Tailings and Soils}

Based upon site examination, a review of the Iimited data portraying the physical properties of the tailings, and discussions with earthmoving contractors in the area, it appears that there would be no difficulty in removing the tailings from the tailings site. The contractor performing this work would be able to use any number of conventional loading methods, e.g. front-end tractor loaders or conveyor belt feed to overhead loading. The possibility of encountering water below the tailings suggests the potential need for a dewatering system when excavating the contaminated subsoil. There is ample room on site for fast loading and easy truck ingress and egress.

To eliminate the possibility of tailings dispersion during loading and transportation operations, dust control equipment and washdown facilities would be provided. The lack of moisture in the tailings and native earth during certain seasons of the year would require the use of dust-preventive methods in the excavation and loading process.

The decontaminated tailings site and surrounding decontaminated areas would be backfilled to natural grade. Local material, all of which must be hauled onto the site, would be used as backfill. No special treatments of the final surface other than establishing native grass cover at the decontaminated tailings site are considered in this assessment.

In option VIIIA, the tailings would be relocated by rail. A spur that served the former mill area of the site could be modified to serve as a railroad loading area for the tailings. A loadout facility would also have to be constructed to permit efficient loading of the train.

\section{2 .2 Transportation of the Materials}

Because of inefficiencies of short hauls by rail, truck transportation is the method proposed to move tailings in options II through VII. Railroad transportation was a consideration in option VIIIA, and for comparison, truck transportation was assumed in option VIIIB. 
Slurry pipeline technology also has been evaluated, but because of the high costs involved, potential unavailability of water from the colorado River or other sources, and the need to dewater at the disposal site, it was not considered feasible.

The use of conveyors in transporting the tailings and contaminated materials has been investigated briefly to assess its viability. While any conclusive statement is very dependent upon the site- and route-specific parameters, some generalizations can be made about the viability of conveyors in this application:

(a) The longer the life of the project, the more attractive the use of conveyors becomes.

(b) The greater the mass to be moved, the more attractive the use of conveyors becomes.

(c) Conveyors can be more attractive in difficult terrain.

However, there are many complications involved in the use of conveyors, many of which are difficult to quantify. Public acceptance, acquisition of rights-of-way and permits within a reasonable time frame, and environmental impact are considerations that cloud the evaluation of conveyors.

With all of the factors considered, it appears that truck transportation of tailings and contaminated materials is generally preferable to conveyors. At such time as a specific site is chosen, a detailed evaluation would disclose whether this generalization holds true for the selected site and routes.

Truck transportation is the most economical means of hauling materials to the storage sites, except for the unspecified DeBeque site. Trucks could move the materials at the rate of about 4,800 tons/day, except for disposal by truck near DeBeque, in which case the tailings would be removed at the rate of 3,700 tons/day. At this rate, working 5 days/wk, $10 \mathrm{mo} / \mathrm{yr}$. all materials could be removed in 2.5 to 3 yr. This method assumes the use of conventional truck and/or truck-trailer combinations. Contamination control measures, such as covers and washdown facilities for the trucks, are included as capital costs associated with transportation. No costs are included for repair and maintenance of public roads, based on the assumption that legal load limits will not be exceeded and the state gasoline taxes provide the needed revenues for such repair and maintenance.

Transportation costs for rail include: (a) hauling costs consisting of the leasing and operating of a 2,200-ton capacity unit train, and (b) capital costs, including loading and unloading facilities, washdown equipment, and sealing of 
rail car beds. Operating at two cycles per day, a 2,200-ton capacity unit train could completely remove the tailings in less than $3 \mathrm{yr}$.

\section{2 .3 Disposal at Alternative sites}

A discussion of proposed disposal sites is given in Chapter 8. Each disposal site has different physical, geological, and hydrological characteristics. However, because the Federal Government, with input from the state, is ultimately responsible for the selection of disposal sites, there is no assurance that any of the disposal sites considered in this report will be selected. Nevertheless, an effort was made to quantify these differences based on what limited data for each site were available and to show the costs that would result if the contaminated materials were actually disposed of at the sites discussed in Chapter 8.

Vegetative cover is presently established on about $30 \%$ of the surface area of all disposal sites, and average rainfall at all sites is approximately 9 in./yr. All areas are accessible by using a combination of paved, gravel, and dirt roads. Where existing dirt roads are to be used in hauling tailings by truck, the cost estimates include the construction of a gravel-based surface sufficient to handle the heavy loads.

The disposal sites selected can be isolated from drainage basins naturally or by dikes and drainage ditches. The procedure for depositing the tailings would involve removing cover materials from the site in a strip-mining operation, emplacing the tailings, and covering the tailings with previously removed cover materials to a depth of at least $3 \mathrm{~m}$. The stabilized disposal site would be gently sloped and contoured to minimize the potential for water erosion. Figure $9-2$ is a schematic representation of how these disposal sites would be developed.

The alternative sites evaluated are shown in Table 8-1. The costs for the disposal options are shown in Table 9-1 and range from about $\$ 23,000,000$ for option II to about $\$ 41,900,000$ for Option VIIIB.

The differences in costs among options III through VII are small because the distances between the tailings and disposal sites are similar. (Haul costs are strongly dependent on distance and are important components of the total costs.)

There are also differences among capital costs associated with transportation and disposal site costs. These differences are attributable to varying requirements for upgrading the access to disposal sites, for preparing the site, and for protecting the disposed tailings from erosion.

In Options II through VIII, the estimated costs include cleanup of windolown tailings; decontamination of the millsite, 
the ore storage area, and the state repository; backfilling the decontaminated area at and around the former tailings site: establishing vegetative cover at and around the former tailings site; covering all tailings and contaminated materials at the disposal site with $3 \mathrm{~m}$ of cover material; and contouring the stabilized disposal site and placing $0.3 \mathrm{~m}$ of riprap for erosion control.

An effort was made to identify an area for disposal of tailings from both the Grand Junction and Rifle sites. The city of DeBeque, located about rnidway between Grand Junction (35 mi northeast of Grand Junction) and Rifle, was chosen for this evaluation. As mentioned in Paragraph 8.1, the site within the DeBeque area (site 22) is unspecified but is assumed to meet the qualifications of a disposal site.

In option VIIIA the tailings would be transported to the DeBeque area via rail. It is assumed that a 1 -mi-long rail spur can be extended directly to the site. It is also assumed that this site could be used for disposal of the tailings from the Rifle sites as well as from the Grand Junction site. The total estimated cost of Option VIIIA is $\$ 39,500,000$.

If, by contrast, the tailings were transported by truck from Grand Junction to DeBeque (Option VIIIB), the total estimated cost of tailings cleanup and disposal is $\$ 41,900,000$. savings are realized in the trucking option because the load out and unloading facilities are not required. However, these savings are more than offset by the increased haul costs and longer duration of the project (resulting from the reduced removal rate of 3,700 tons/day).

\subsection{ANALYSES OF COSTS AND BENEFITS}

9.3.I Health Benefits

Each of the remedial action alternatives considered in this chapter has an associated health impact that would be avoided as a result of the action. These avoided health effects are referred to as health benefits. In chapter 3 the estimated number of health effects was determined for the Grand Junction tailings pile in its present condition. In order to estimate the number of health benefits attributable to a particular remedial action, the effect of that remedial action on radon exhalation from the pile must be determined, because the health effects calculated in chapter 3 were associated with radon daughters. While there are some benefits associated with actions such as fencing, these have not been quantified in this assessment of health benefits.

In this evaluation, the health benefit of each option is calculated from the reduction in radon exhalation that is expected for that option. In accordance with proposed requirements for stabilization of uranium mill tailings, radon 
flux was assumed to be reduced from the present value (as conservatively calculated) of $1,000 \mathrm{pCi} / \mathrm{m}^{2}-\mathrm{s}$, to the required flux of $2 \mathrm{pCi} / \mathrm{m}^{2}-\mathrm{s}$ for option $\mathrm{I}$. In all other options, radon flux was assumed to be reduced to zero by the removal of the tailings. Since health effects are proportional to radon flux, the present health effects rate was estimated to be reduced by $99.8 \%$ by stabilization in-place and $100 \%$ by tailings removal.

The potential cancer cases avoided (health benefits) for each option are given as a function of time in part A of Table 9-2. The cost per potential cancer case avoided for each option is included as part $B$ in Table 9-2.

As an alternative to the presentation in Table 9-2, the number of potential cancer cases avoided per million dollars expended were calculated and plotted in Figure 9-3. Option I yields the maximum health benefit per unit cost, whereas option VIIIB yields the minimum benefit per unit cost.

\subsubsection{Land Value Benefits}

The Grand Junction tailings site has considerable potential for future use because of its proximity to the Denver and Rio Grande Western Railroad tracks, to the industrial park area, and to the business district of Grand Junction. The industrial land north of the tailings site has values ranging from $\$ 2,000$ to $\$ 13,000 / a c r e$. The residential land east of the site is valued at $\$ 8,000 /$ acre.

The proposed remedial action described under option I (stabilization of the tailings at the present site with $3 \mathrm{~m}$ of cover material and cleanup of the windblown contaminated area) would allow the northern portion of the site to be used without restriction, and its current estimated value could increase from its present value of $\$ 2,000 /$ acre to approximately $\$ 6,000 / a c r e$. The tailings portion of the site could have limited uses such as storage or parking. Its value would increase from its current estimated value of $\$ 33 /$ acre, but would remain depressed compared to surrounding values due to its limited use status and the objectionable sight of a pile almost $20 \mathrm{ft}$ in height.

The warning that presently exists for new construction surrounding the site regarding the potential of radiation hazard could be eliminated. This action would doubtless increase property values in the vicinity of the site.

Under Options II through VIII the tailings would be removed and the area decontaminated. The entire tailings site would thus be available for unlimited usage and could have an average market value of about $\$ 10,000 / a c r e$. Under these options the value of the total site would increase from its present value of about $\$ 12,500$ to about $\$ 650,000$. 


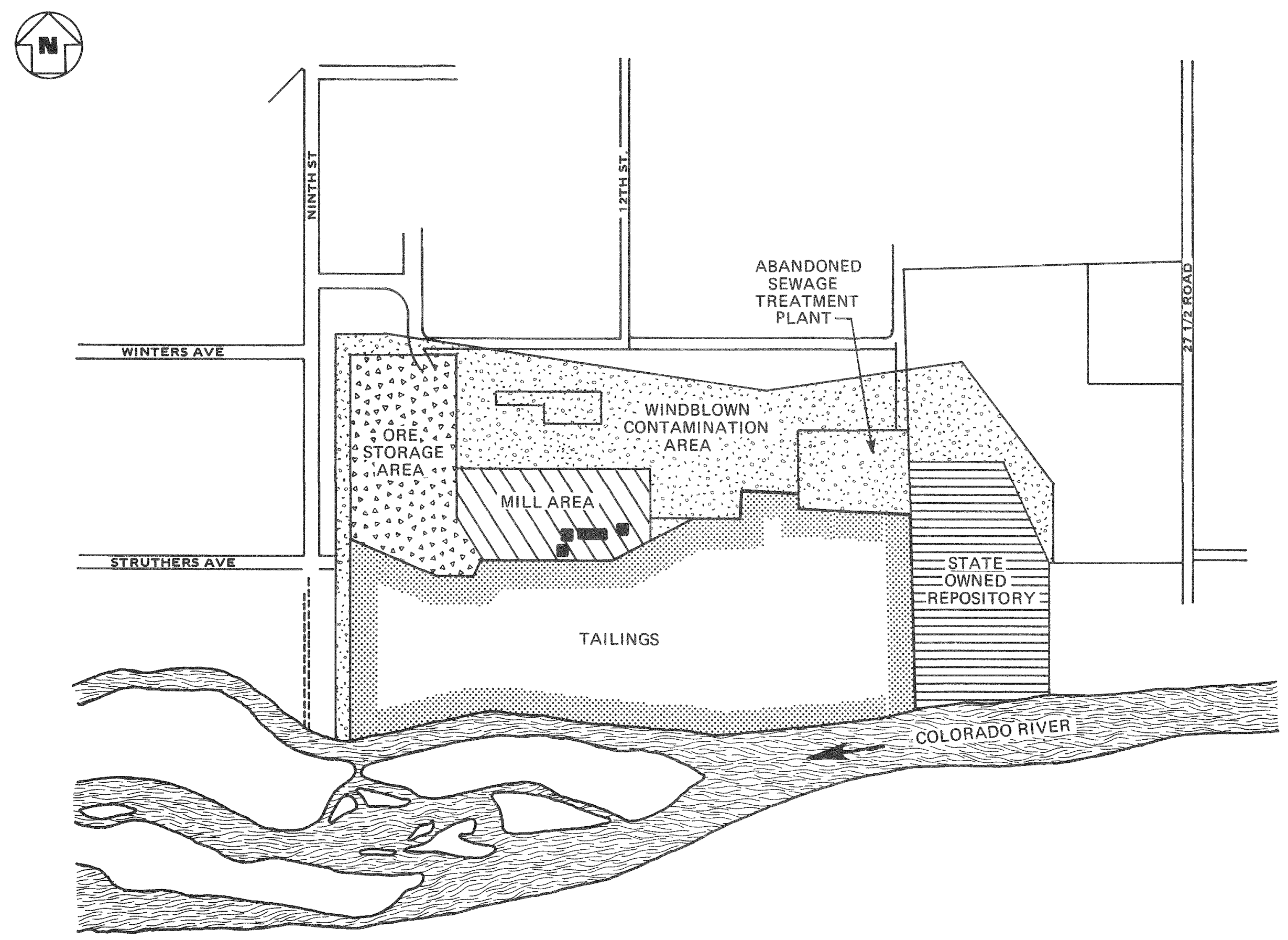

ASSUMED DEPTHS OF REMOVAL

TAILINGS - REMOVE AN AVERAGE 3 FT OF SUBSOIL

ORE STORAGE AREA - REMOVE AN AVERAGE 3 FT OF SOIL OVER $70 \%$ OF AREA

MILL AREA - REMOVE AN AVERAGE 2 FT OF SOIL

WINDBLOWN CONTAMINATION AREA - REMOVE AN AVERAGE

STATE OWNED REPOSITORY - REMOVE AN AVERAGE $1 \mathrm{FT}$ OF SUBSOIL

LEGEND

$\therefore$ ORE STORAGE AREA

DI MILLAREA

STATE OWNED REPOSITORY

$\therefore$ WINDBLOWN CONTAMINATION AREA

TAILINGS AREA

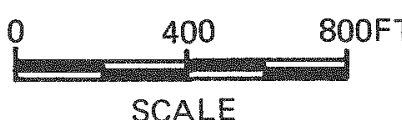




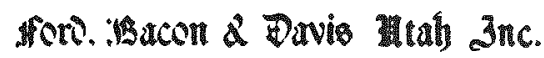

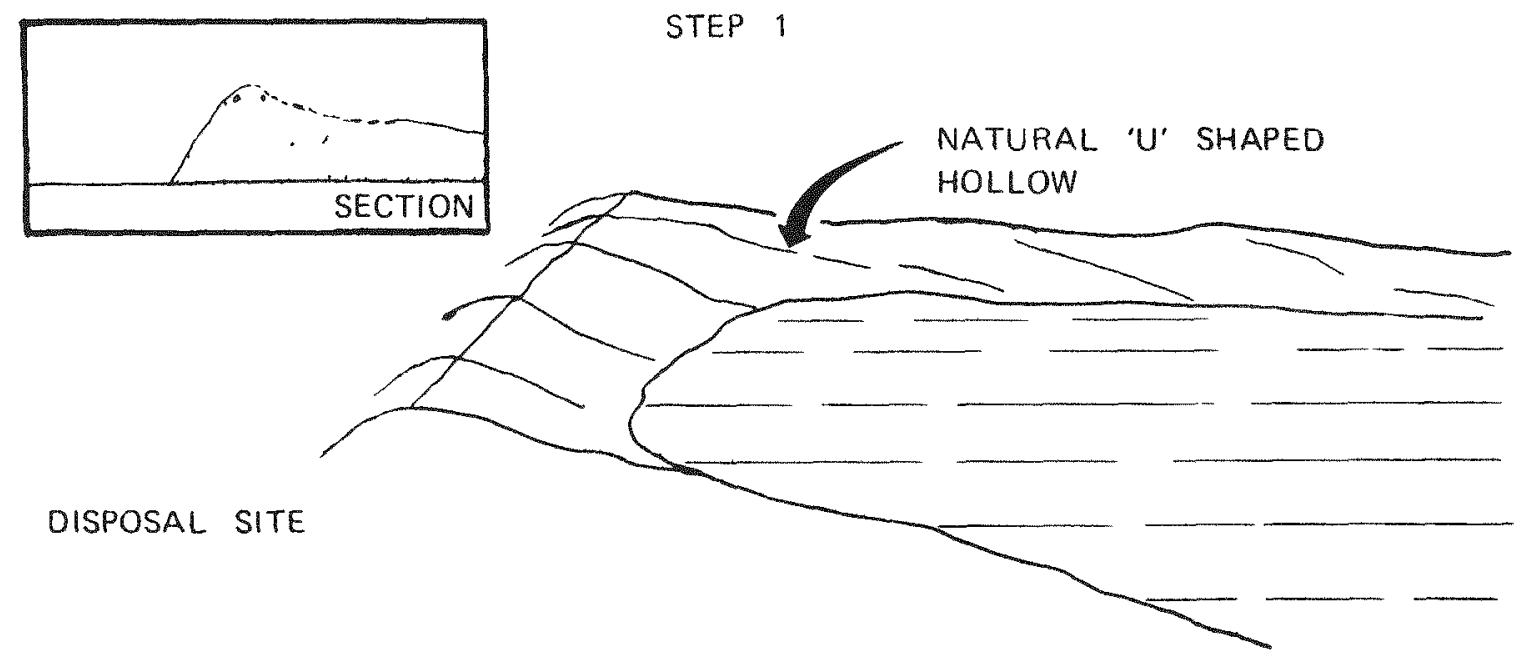

STEP 2
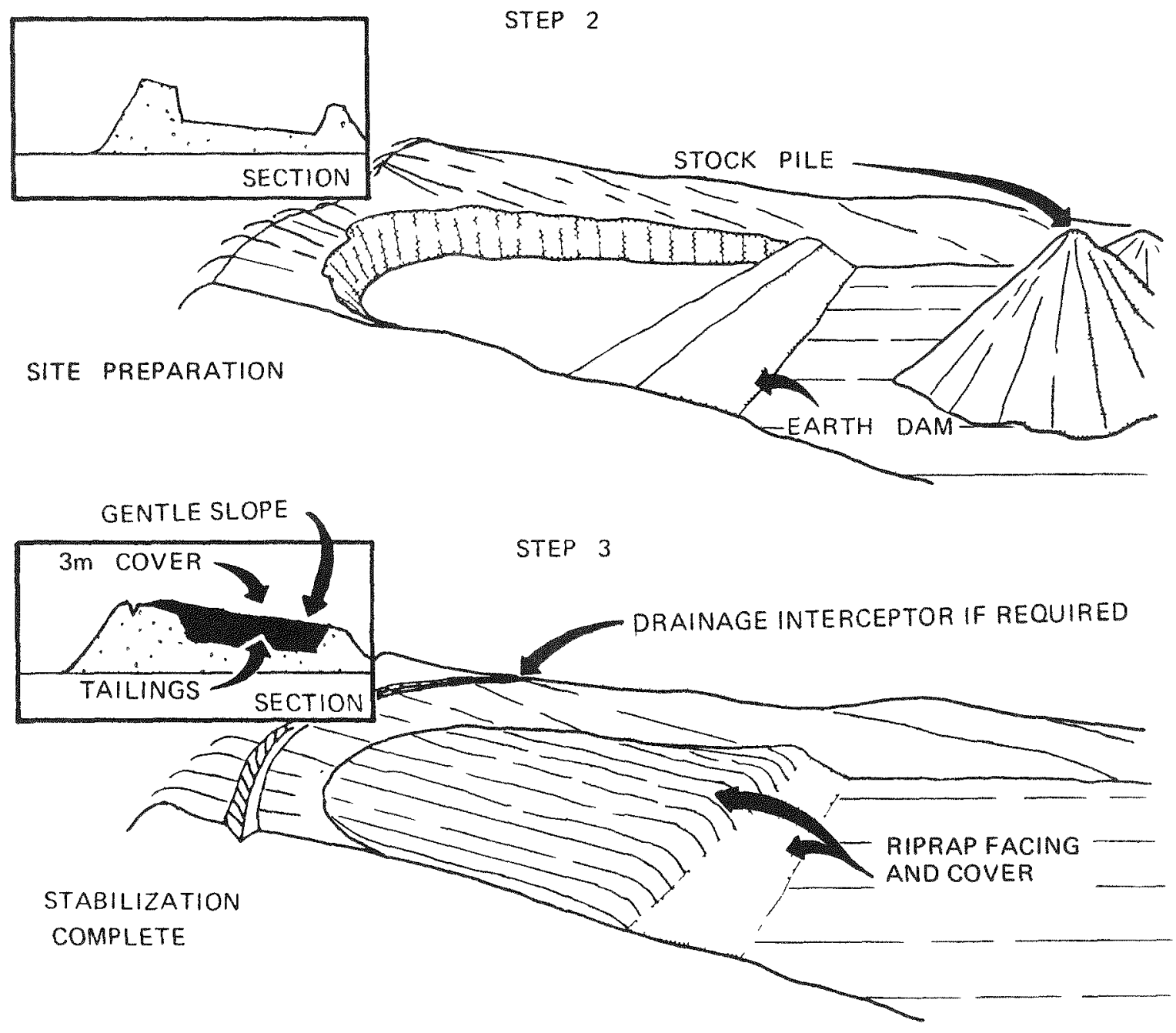

FIGURE 9-2. SCHEMATIC OF TYPICAL TAILINGS DISPOSAL SITE 


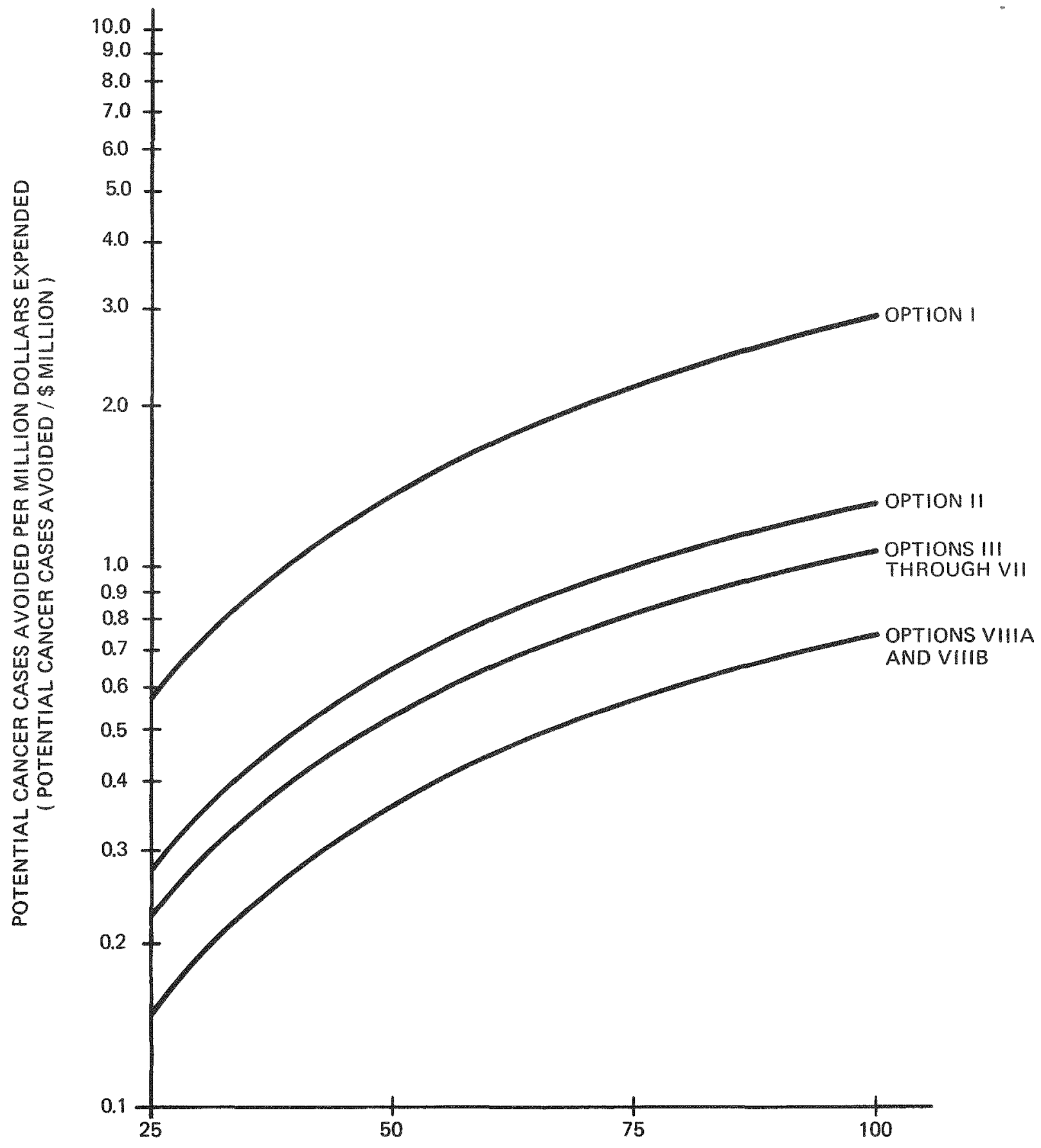

YEARS AFTER REMEDIAL ACTION

FIGURE 9-3. POTENTIAL CANCER CASES AVOIDED PER MILLION DOLLARS EXPENDED 
TABLE 9-1

SUMMARY OF STABILIZATION AND DISPOSAL COSTS ${ }^{a}$

\begin{tabular}{|c|c|c|c|c|c|c|c|c|c|c|}
\hline & & \multicolumn{9}{|c|}{ Option } \\
\hline & & $I$ & II & III & IV & $\mathrm{V}$ & VI & VII & VIIIA & VIIIB \\
\hline 1 . & Tailings site & 5.7 & 4.4 & 4.4 & 4.4 & 4.4 & 4.4 & 4.4 & 6.6 & 4.4 \\
\hline 2. & $\begin{array}{l}\text { Off-Site other } \\
\text { than Windblown }\end{array}$ & -- & -- & -- & -- & -- & -- & -- & -- & -- \\
\hline \multirow{3}{*}{$\begin{array}{l}3 . \\
4 .\end{array}$} & Off-Site Windblown & 0.3 & 0.3 & 0.3 & 0.3 & 0.3 & 0.3 & 0.3 & 0.3 & 0.3 \\
\hline & Transportation & & & & & & & & & \\
\hline & $\begin{array}{l}\text { a. Capital Costs } \\
\text { b. Haul Costs }\end{array}$ & - & $\begin{array}{l}0.6 \\
5.1\end{array}$ & $\begin{array}{l}1.7 \\
8.0\end{array}$ & $\begin{array}{l}1.1 \\
7.8\end{array}$ & $\begin{array}{l}0.6 \\
8.6\end{array}$ & $\begin{array}{l}0.9 \\
8.2\end{array}$ & $\begin{array}{l}1.3 \\
8.2\end{array}$ & $\begin{array}{l}6.0 \\
8.4\end{array}$ & $\begin{array}{r}1.1 \\
19.9\end{array}$ \\
\hline 5. & Disposal site & -- & 4.4 & 4.3 & 5.0 & 3.3 & $4 \cdot 0$ & 4.1 & 4.1 & 3.6 \\
\hline 6. & $\begin{array}{l}\text { Total cleanup } \\
\text { (sum of lines } 1 \\
\text { through } 5 \text { ) }\end{array}$ & 6.0 & 14.8 & 18.8 & 18.6 & 17.2 & 17.9 & 18.3 & 25.3 & 29.4 \\
\hline 7. & $\begin{array}{l}\text { Engineering Design, } \\
\text { Construction Management } \\
\text { ( } 30 \% \text { of line } 6 \text {, less } \\
\text { line } 4 \mathrm{~b} \text { ) }\end{array}$ & 1.8 & 2.9 & 3.2 & 3.3 & 2.6 & 2.9 & 3.0 & 5.1 & 2.8 \\
\hline 8. & $\begin{array}{l}\text { Total }{ }^{\mathrm{b}} \\
(\text { sum of lines } 6 \text { and } 7)\end{array}$ & 7.8 & 17.7 & $22 \cdot 0$ & 21.9 & 19.8 & 20.7 & $21 \cdot 3$ & 30.4 & 32.2 \\
\hline 9. & $\begin{array}{l}\text { Contingency } \\
(30 \% \text { of line } 8)\end{array}$ & 2.4 & 5.3 & 6.6 & 6.6 & 5.9 & 6.2 & 6.3 & 9.1 & 9.7 \\
\hline 10. & $\begin{array}{l}\text { GRAND TOTAL } \\
(\text { sum of lines } 8 \text { and } 9)\end{array}$ & 10.2 & 23.0 & 28.6 & 28.5 & 25.7 & 27.0 & 27.7 & 39.5 & 41.9 \\
\hline
\end{tabular}

${ }^{a}$ Costs are presented in millions of year 1980 dollars. Costs do not include remedial action for off-site properties (see Chapter 7).

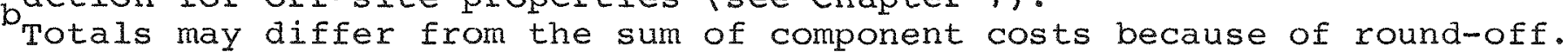


TABLE 9-2

POTENTIAL CANCER CASES AVOIDED* AND COST PER POTENTIAL CASE AVOIDED

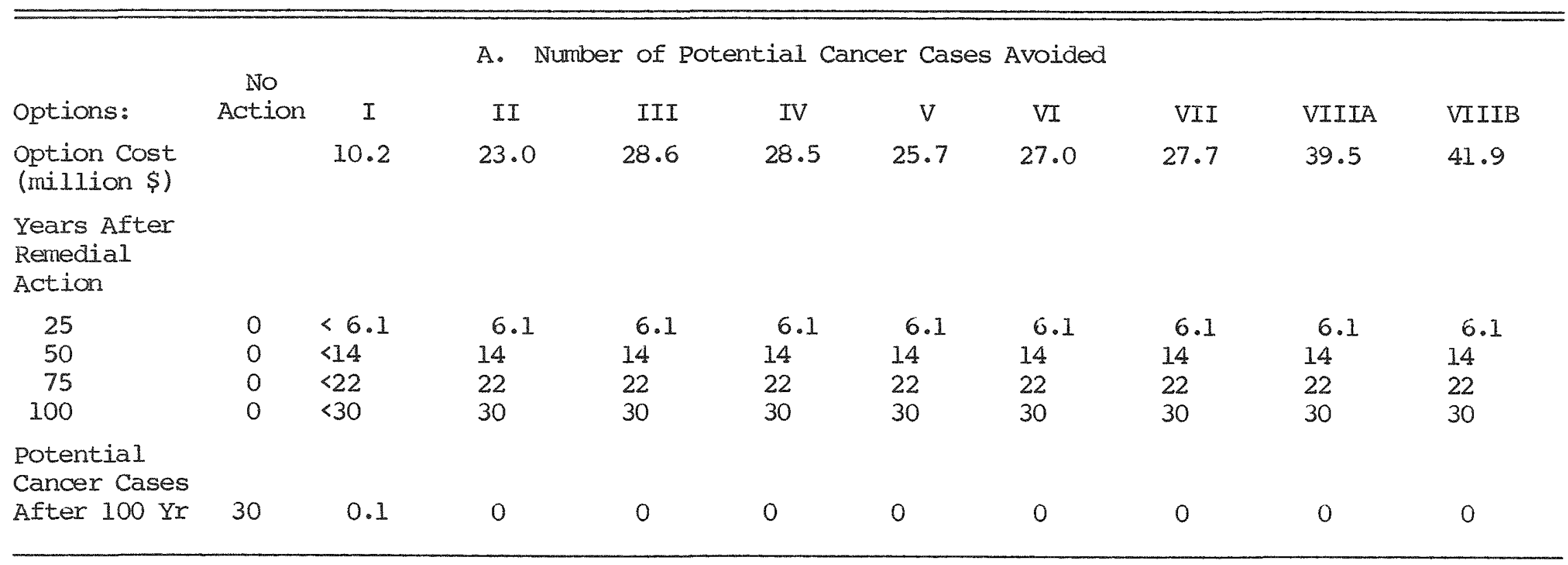

No

B. Cost Per Potential Cancer Case Avoided (Million \$)

\begin{tabular}{|c|c|c|c|c|c|c|c|c|c|c|}
\hline Options: & Action & I & II & III & IV & V & VI & VII & VIIIA & VIIIB \\
\hline $\begin{array}{l}\text { Option Cost } \\
\text { (million } \$ \text { ) }\end{array}$ & & 10.2 & 23.0 & 28.6 & 28.5 & 25.7 & 27.0 & 27.7 & 39.5 & 41.9 \\
\hline \multicolumn{11}{|l|}{$\begin{array}{l}\text { Years After } \\
\text { Remedial } \\
\text { Action }\end{array}$} \\
\hline $\begin{array}{r}25 \\
50 \\
75 \\
100\end{array}$ & & $\begin{array}{l}1.7 \\
0.73 \\
0.46 \\
0.34\end{array}$ & $\begin{array}{l}3.8 \\
1.6 \\
1.0 \\
0.77\end{array}$ & $\begin{array}{l}4.7 \\
2.0 \\
1.3 \\
0.95\end{array}$ & $\begin{array}{l}4.7 \\
2.0 \\
1.3 \\
0.95\end{array}$ & $\begin{array}{l}4.2 \\
1.8 \\
1.2 \\
0.86\end{array}$ & $\begin{array}{l}4.4 \\
1.9 \\
1.2 \\
0.90\end{array}$ & $\begin{array}{l}4.5 \\
2.0 \\
1.3 \\
0.92\end{array}$ & $\begin{array}{l}6.5 \\
2.8 \\
1.8 \\
1.3\end{array}$ & $\begin{array}{l}6.9 \\
3.0 \\
1.9 \\
1.4\end{array}$ \\
\hline
\end{tabular}

*Based on $6.3 \%$ declining growth rate. 
1. Nuclear Regulatory Comission; 10 CFR, Parts 40 and 150, "Uranium Mill Tailings Licensing"; Federal Register, Vol 44, No. 166; Proposed Rules; Aug 24, 1979. 
Perms/Abbreviations

absorbed dose

$A-E$

AEC

alpha particle $(\alpha)$

amenability

a noma $1 y$

(mobile gamma survey)

aquifer

atmospheric pressure

\section{Definitions}

Radiation energy absorbed per unit mass.

Architect-Engineer.

Atomic Energy Commission.

A positively charged particle emitted from certain radioactive materials. It consists of two protons and two neutrons, hence is identical with the nucleus of the helium atom. It is the least penetrating of the common radiations $(\alpha, \beta, \gamma)$, hence is not dangerous unless alpha-emitting substances have entered the body.

The relative ease with which a mineral can be removed from an ore by a particular process.

Any location detected by the mobile gamma survey where the recorded counts per second $(\mathrm{c} / \mathrm{s})$ from the 1 arge gama-ray detector exceed the determined background for that area by 50 or more c/s.

A water-bearing formation below the surface of the earth: the source of wells. A confined aquifer is overlain by relatively impermeable rock. An unconfined aquifer is one associated with the water table.

Pressure exerted on the earth by the mass of the atmosphere surrounding the earth; expressed in inches of mercury (at sea level and $0^{\circ} \mathrm{C}$, standard pressure is 29.921 in. $\mathrm{Hg}$ ). 
background radiation

beta particle ( $\beta$ )

BEIR

BOM (USBOM)

CHES

Curie (Ci)

daughter product

diurnal

dose equivalent

EPA (USEPA)

ERDA (USERDA)
Naturally occurring low-level radiation to which all life is exposed. Background radiation levels vary from place to place on the earth.

A particle emitted from some atoms undergoing radioactive decay. A negatively charged beta particle is identical to an electron. A positively charged beta particle is called a positron. Beta radiation can cause skin burns and beta emitters are harmful if they enter the body.

Biological Effects of Ionizing Radiation.

Bureau of Mines.

Center for Health and Environmental studies, Brigham Young University, Provo, Utah.

The unit of radioactivity of any nuclide, defined as precisely equal to $3.7 \times 10^{10}$ disintegrations/second.

The nuclide remaining after a radioactive decay. A daughter atom may itself be radioactive, producing further daugher products.

Daily, cyclic (happening each day or during the day).

A term used to express the amount of effective radiation when modifying factors have been considered (the numerical product of absorbed dose and quality factor).

Environmental protection Agency.

Energy Research and Development Administration. 
ERDA-GJO

erg

external gamma radiation (EGR)

exposure

exhalation

FB\&DU

fixed alpha

gamma background

gamma ray $(\gamma)$
Energy Research and Development Administration-Grand Junction office.

A basic unit of work or energy in the centimeter-gram-second system $\left(1\right.$ erg $=7.4 \times 10^{-8}$ ft-1b, or $10^{-7}$ joule).

Gamma radiation emitted from a source(s) external to the body, as opposed to internal gamma radiation emitted from ingested or inhaled sources.

Related to electrical charge produced in air by ionizing radiation per unit mass of air.

Emission of radon from earth (usually thought of as coming from a uranium tailings pile, but actually from any location).

Ford, Bacon \& Davis Utah Inc.

particulate alpha emitting isotopes which have become imbedded in otherwise nonradioactive surfaces and which cannot be removed by standard decontamination techniques.

Natural gamma ray activity everywhere present, originating from two sources: (1) cosmic radiation, bombarding the earth's atmosphere continually, and (2) terrestrial radiation. Whole body absorbed dose equivalent in the U.S. due to natural gamma background ranges from about 60 to about $125 \mathrm{mrem} / \mathrm{yr}$.

High energy electromagnetic radiation emitted from the nucleus of a radioactive atom, with specific energies for the atoms of different elements and having high penetrating power.

Grand Junction Office. 
ground water

health effect

heap leaching

HEW (USHEW)

insult

Interim Primary Drinking Water Regulations

iso-exposure line

isotope

JCAE

knot

man-rem (person-rem)
Subsurface water in the zone of full saturation which supplies wells and springs.

Adverse physiological response from tailings (in this report, one health effect is defined as one case of cancer from exposure to radioactivity).

A process for removing uranium from ore, tailings, or other material wherein the material is placed on an impermeable pad and wetted with appropriate reagents. The uranium solution is collected for further processing.

Department of Health, Education, and Welfare.

Negative impact on the environment or the health of individuals.

Title No. 40 of the code of Federal Regulations, Chapter 1 , Part 141, dated Dec 24, 1975 and effective June 24, 1977.

A line drawn on a map to connect a set of points having the same exposure rate.

One of two or more species of atoms with the same atomic numbers (the same chemical element) but with aifferent atomic weights. Isotopes usually have very nearly the same chemical properties, but somewhat different physical properties.

Joint Committee on Atomic Energy.

A unit of velocity, approximately equal to $1.15 \mathrm{mi} / \mathrm{hr}$.

A unit used in health physics to compare the effects of different amounts of radiation on groups 


\begin{abstract}
$\mu \mathrm{R} / \mathrm{hr}$
$\mathrm{mR} / \mathrm{hr}$

$\mathrm{MeV}$

maximum permissible concentration (MPC)
\end{abstract}

NAS

NIOSH

noble gas

NRC

nuclide

ORNL

ORP-LVF (EPA)

$\mathrm{pCi} / 1$

$\mathrm{pCi} / \mathrm{g}$

$\mathrm{pCi} / \mathrm{m}^{2}-\mathrm{s}$ of people. It is obtained by summing individual dose equivalent values for all people in the population.

Microroentgen per hour $\left(10^{-6}\right.$ $\mathrm{R} / \mathrm{hr}$ ).

Miliroentgen per hour $\left(10^{-3}\right.$ $\mathrm{R} / \mathrm{hr}$ ).

Million electron volts.

The highest concentration in air or water of a particular radionuclide permissible for occupational or general exposure without taking steps to reduce exposure.

National Academy of sciences.

National Institute for occupational safety and Health.

one of the gases, such as helium, neon, radon, etc., with completely filled electron shells which is therefore chemically inert.

Nuclear Regulatory Commission.

A general term applicable to all atomic forms of the elements; nuclides comprise all the isotopic forms of all the elements. Nuclides are distinguished by their atomic number, atomic mass, and energy state.

Oak Ridge National Laboratory.

Office of Radiation programs, Las Vegas Facility (Environmental Protection Agency).

Picocurie per liter $\left(10^{-12} \mathrm{ci} / 1\right)$

Picocurie per gram $\left(10^{-12} \mathrm{ci} / \mathrm{g}\right)$

Picocurie per square meter per second $\left(10^{-12} \mathrm{ci} / \mathrm{m}^{2}-\mathrm{s}\right)$ 
PHS (USPHS)

quality factor ( $Q F$ )

rad

radioactivity

radioactive decay chain

radium

radon

radon background
Public Health Service.

An assigned factor that denotes the modification of the effectiveness of a given absorbed dose by the linear energy transfer.

The basic unit of absorbed dose of ionizing radiation. A dose of 1 rad means the absorption of 100 ergs of radiation energy per gram of absorbing material.

The spontaneous decay or disintegration of an unstable atomic nucleus, usually accompanied by the emission of ionizing radiation.

A succession of nuclides each of which transforms by radioactive disintegration into the next until a stable nuclide results. The first member is called the parent, the intermediate members are called daughters, and the final stable member is called the end product.

A radioactive element, chemically similar to barium, formed as a daughter product of uranium $\left(238_{U}\right)$. The most comon isotope of radium, $226_{\mathrm{Ra}}$, has a halflife of 1,620 yr. Radium is present in all uranium-bearing ores. Trace quantities of both uranium and radium are found in all areas, contributing to the background radiation.

A radioactive, chemically inert gas. The nuclide $222 \mathrm{Rn}$ has a half-life of 3.8 days and is formed as a daughter product of radium $\left(226_{\mathrm{Ra}}\right)$.

Low levels of radon gas found in air resulting from the decay of naturally occurring radium in the soil. 
radon concentration

radon daughter

radon daughter concentration (RDC)

radon Elux

raffinate

recharge

rem

(roentgen equivalent man)

residual value
The amount of radon per unit volume. In this assessment. the average value for a $24-\mathrm{hr}$ period of atmospheric radon concentrations, determined by collecting data for each 30-min period of a 24-hr day and averaging these values.

one of several short-lived radioactive daughter products of radon (several of the daughters emit alpha particles).

The concentration in air of short-lived radon daughters, expressed either in $\mathrm{pCi} / 1$ or in terms of working level (WL).

The quantity of radon emitted from a surface in a unit time per unit area (typical units are in $\left.\mathrm{pCi} / \mathrm{m}^{2}-\mathrm{s}\right)$.

The liquid part remaining after a product has been extracted in a solvent extraction process.

The processes by which water is absorbed and added to the zone of saturation of an aquifer, either directly into the formation or indirectly by way of another formation.

The unit of dose equivalent of any ionizing radiation which produces the same biological effect as a unit of absorbed dose of ordinary x-rays, numerically equal to the absorbed dose in rads multiplied by the appropriate quality factor for the type of radiation. The rem is the basic recorded unit of accumulated dose to personnel.

The value of minerals in tailings material. 
emission of $1.3 \times 10^{5} \mathrm{MeV}$ of potential alpha energy. This level is equivalent to the energy produced in the decay of the daughter products RaA, RaB, RaC, and $\mathrm{RaC}^{\circ}$ that are present under equilibrium conditions in a liter of air containing $100 \mathrm{pCi}$ of $\mathrm{Rn}-222$. It does not include decay of RaD (22-yr half-life) and subsequent daughter products.

working level month (WLM)

One WLM is equal to the exposure received from 170 WL-hours. 